Dostępne online www.journals.wco.pl/los

Zeszyty Naukowe WCO, Letters in Oncology Science 2017;14(S1):1-88

CrossMark
Letters in Oncology Science

ISSN 2543-6724

ZESZYTY NAUKOWE WIELKOPOLSKIEGO CENTRUM ONKOLOGII

\title{
Konferencja Polskiego Towarzystwa Fizyki Medycznej
}

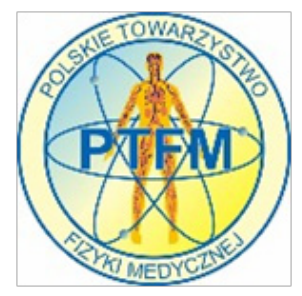

\section{1-3 czerwca 2017, Poznań www.wco.pl/ptfm2017}

Komitet Naukowy

prof. dr hab. Julian Malicki

prof. dr hab. Natalia Golnik

prof. dr hab. Ryszard Krzyminiewski

prof. dr hab. Leszek Kubisz

prof. dr hab. Paweł Kukołowicz prof. dr hab. Krzysztof Ślosarek prof. dr hab. Michał Waligórski

dr hab. Tomasz Piotrowski

dr hab. Armand Cholewka dr Renata Kabacińska

mgr Ryszard Kowski

\section{Komitet organizacyjny}

dr hab. Tomasz Piotrowski

dr Bernadetta Dobosz

dr hab. Dorota Hojan-Jezierska

mgr Monika Jędrzejewska prof. dr hab. Maciej Kozak

mgr Anna Zawadzka

dr Grzegorz Zwierzchowski 


\section{Spis treści}

Ramowy program konferencji

$\begin{array}{ll}\text { Wykaz plakatów elektronicznych } & 7\end{array}$

Wykłady edukacyjne i wystąpienia ustne $\quad 9$

$\begin{array}{ll}\text { Sesje plakatowe } & 25\end{array}$

$\begin{array}{ll}\text { Plakaty elektroniczne } & 43\end{array}$

$\begin{array}{ll}\text { Indeks autorów } & 81\end{array}$

\section{Wykaz skrótów}

WE - wykład edukacyjny

WU - wystąpienie ustne podczas sesji plenarnej

SP - prezentacja ustna podczas sesji plakatowej

EP - plakat elektroniczny

NT - nanotechnologia

BS - biosygnały

OR - ochrona radiologiczna

BT - brachyterapia

TT - teleradioterapia

DO - diagnostyka obrazowa 


\section{Ramowy program konferencji}

\begin{tabular}{|c|c|c|}
\hline & & CZWARTEK, o1 CZERWIEC 2017 \\
\hline \multicolumn{2}{|c|}{$09.00-09.05$} & Otwarcie Konferencji \\
\hline \multicolumn{2}{|c|}{$09.05-09.20$} & Wystąpienie prezesa PTFM \\
\hline \multicolumn{2}{|c|}{$09.20-09.35$} & Wystąpienie Konsultanta Krajowego \\
\hline \multicolumn{3}{|r|}{$\begin{array}{l}\text { SESJA PLENARNA: NANOTECHNOLOGIA W MEDYCYNIE } \\
\text { prowadzący: dr Bernadeta Dobosz, prof. Maciej Kozak }\end{array}$} \\
\hline 09.35-10.00 & WE-NT-O01 & Figiel H. Nanotechnologia w medycynie \\
\hline \multirow{4}{*}{$10.00-11.00$} & WU-NT-002 & $\begin{array}{l}\text { Blasiak B i wsp. Zastosowanie magnetycznych nanocząstek typu rdzeń/powłoka do } \\
\text { obrazowania molekularnego guzów mòzgu }\end{array}$ \\
\hline & WU-NT-003 & $\begin{array}{l}\text { Stodolak-Zych E, wsp. Nanokompozytowe membrany włókniste - możliwości } \\
\text { zastosowań medycznych }\end{array}$ \\
\hline & WU-NT-004 & $\begin{array}{l}\text { Lachowicz D i wsp. Samoorganizujące się układy polimerowe jako nośniki } \\
\text { piroksykamu }\end{array}$ \\
\hline & WU-NT-005 & $\begin{array}{l}\text { Kmita A i wsp. Nanocząstki ferrytu manganu do potencjalnych zastosowań } \\
\text { w hipertermii magnetycznej }\end{array}$ \\
\hline $11.00-11.20$ & \multicolumn{2}{|r|}{ Przerwa kawowa } \\
\hline \multicolumn{3}{|r|}{$\begin{array}{r}\text { SESJA PLENARNA: BIOSYGNAEY } \\
\text { prowadzący: dr hab. Armand Cholewka, dr Joanna Bauer }\end{array}$} \\
\hline $11.20-11.45$ & WE-BS-0o6 & $\begin{array}{l}\text { Krzyminiewski R. Elektrokardiografia i pulsoksymetria wysokiej rozdzielczości } \\
\text { sygnałowej w diagnostyce medycznej }\end{array}$ \\
\hline $11.45^{-12.10}$ & WE-BS-007 & Hojan-Jezierska D. Protetyka słuchu \\
\hline $12.10-12.25$ & WU-BS-008 & $\begin{array}{l}\text { Man D, Olchawa R. Perspektywy zastosowania interfejs mózg-komputer w inżynierii } \\
\text { biomedycznej }\end{array}$ \\
\hline $12.25-12.55$ & & Przerwa kawowa \\
\hline \multicolumn{3}{|r|}{$\begin{array}{l}\text { SESJA PLENARNA: OCHRONA RADIOLOGICZNA } \\
\text { prowadzący: dr Mirosław Lewocki, prof. Maciej Budzanowski } \\
\end{array}$} \\
\hline $13.00-13.20$ & WE-OR-010 & $\begin{array}{l}\text { Lewocki M i wsp. Ochrona radiologiczna w radioterapii śródoperacyjnej Intrabeam } \\
\text { PRS-500 }\end{array}$ \\
\hline $13.20-13.45$ & WE-OR-011 & $\begin{array}{l}\text { Budzanowski M. Termoluminescencja i wykorzystanie jej w dozymetrii indywidualnej, } \\
\text { środowiskowej i klinicznej promieniowania jonizującego }\end{array}$ \\
\hline $13.45-14.00$ & WU-OR-012 & $\begin{array}{l}\text { Tulik P i wsp. Badanie pól promieniowania mieszanego wokół medycznego } \\
\text { akceleratora liniowego }\end{array}$ \\
\hline $14.00-15.00$ & & Przerwa lunchowa (równolegle, sesje plakatowe) \\
\hline \multicolumn{3}{|r|}{$\begin{array}{r}\text { SESJA PLAKATOWA: NANOTECHNOLOGIA W MEDYCYNIE } \\
\text { Prowadzący: dr Bernadetta Dobosz }\end{array}$} \\
\hline \multirow{6}{*}{$14.05-14 \cdot 35$} & SP-NT-031 & $\begin{array}{l}\text { Józefczak A i wsp. Nanocząstki magnetyczne jako materiał dźwiękoaktywny } \\
\text { w hipertermii ultradźwiękowej }\end{array}$ \\
\hline & SP-NT-032 & $\begin{array}{l}\text { Kotkowiak M i wsp. Hybrydowe koniugaty modyfikowanych chlorofili z RNA oraz } \\
\text { nanocząstkami metalicznymi dla współczesnej fotomedycyny }\end{array}$ \\
\hline & SP-NT-033 & $\begin{array}{l}\text { Pytel B i wsp. Zastosowanie liposomów jako nośników biologicznie czynnych } \\
\text { związków wanadu }\end{array}$ \\
\hline & SP-NT-034 & $\begin{array}{l}\text { Nowicka K i wsp. Kompozyty polimerowe modyfikowane nanomagnetytem dla } \\
\text { zastosowań medycznych }\end{array}$ \\
\hline & SP-NT-035 & $\begin{array}{l}\text { Nowicka K i wsp. Nanokompozyty poliacetalowe modyfikowane funkcjonalizowaną } \\
\text { ceramiką bioaktywną - otrzymywanie i charakterystyka }\end{array}$ \\
\hline & SP-NT-036 & $\begin{array}{l}\text { Andrzejewska W i wsp. Lipopleksy na bazie surfaktantów polikationowych } \\
\text { i pochodnych enhancera genu DMPK w dystrofii miotonicznej typu pierwszego (DM1) }\end{array}$ \\
\hline
\end{tabular}




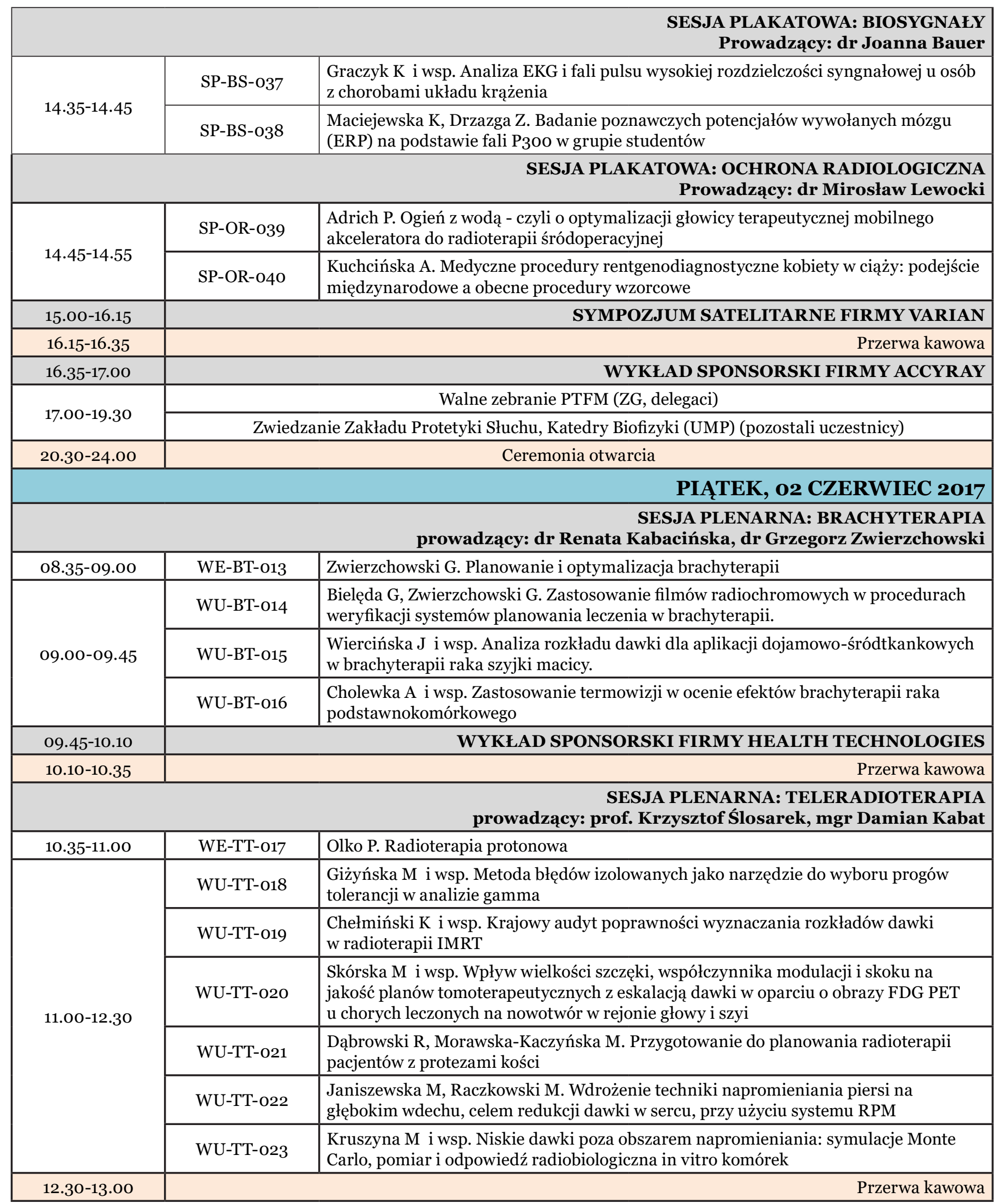




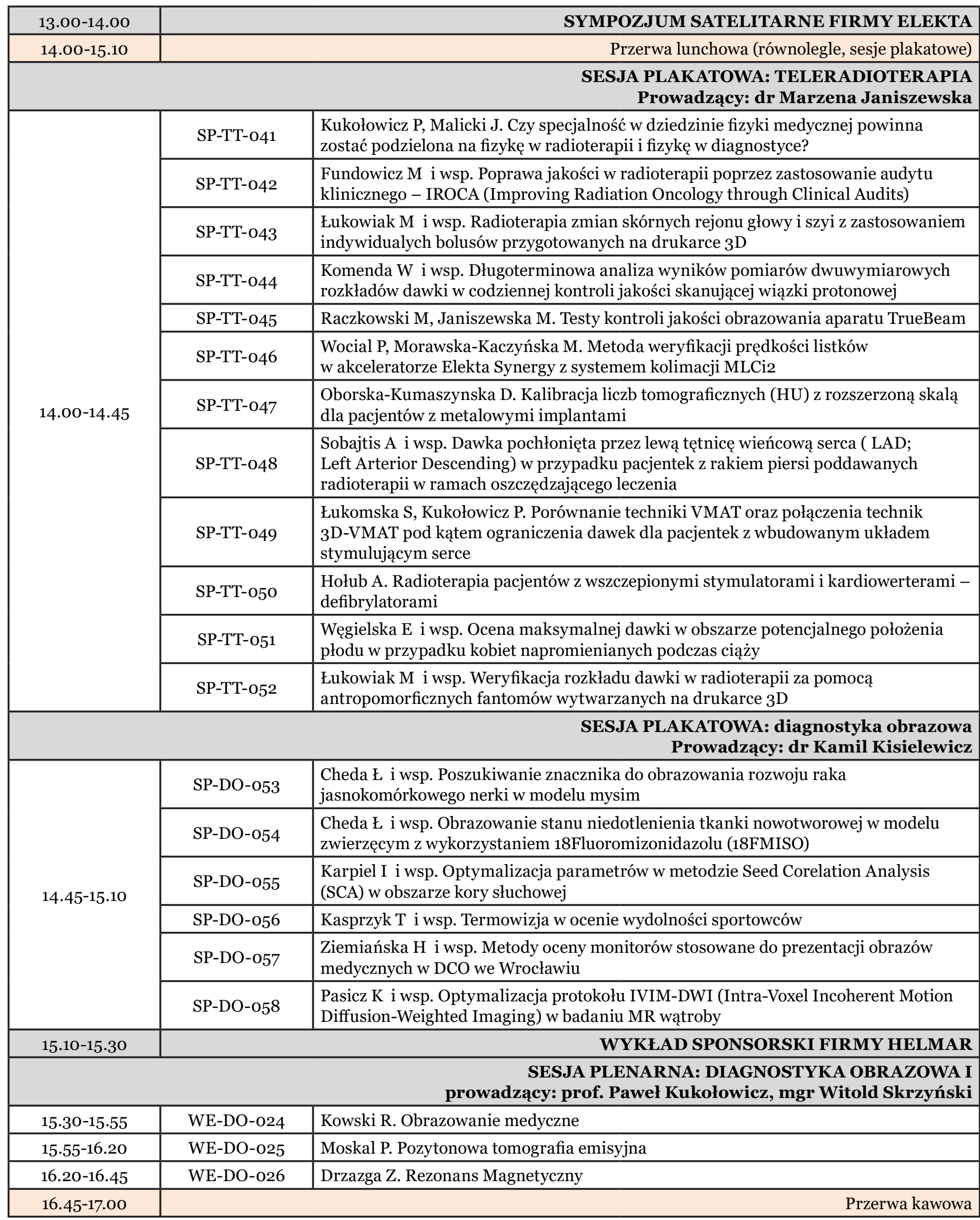




\begin{tabular}{|c|c|c|c|}
\hline & \multicolumn{3}{|c|}{$\begin{array}{l}\text { SESJA PLENARNA: DIAGNOSTYKA OBRAZOWA II } \\
\text { prowadzący: mgr Ryszard Kowski, mgr Monika Jędrzejewska }\end{array}$} \\
\hline \multirow{4}{*}{$17.00-18.00$} & WU-DO-027 & \multicolumn{2}{|c|}{$\begin{array}{l}\text { Koras K, Ginter J. Zastosowanie głębokich konwolucyjnych sieci neuronowych do } \\
\text { klasyfikacji obrazów medycznych: fotografii czerniaka skóry i radiografii planarnej } \\
\text { klatki piersiowej }\end{array}$} \\
\hline & WU-DO-028 & \multicolumn{2}{|c|}{$\begin{array}{l}\text { Fabiszewska E i wsp. Dawki promieniowania X w mammograficznych badaniach } \\
\text { skryningowych w Polsce a stosowane rejestratory obrazu }\end{array}$} \\
\hline & WU-DO-029 & \multicolumn{2}{|c|}{$\begin{array}{l}\text { Zdrojkowski M i wsp. Analiza fraktalna obrazów rezonansu magnetycznego } \\
\text { pacjentów z podejrzeniem nowotworu prostaty }\end{array}$} \\
\hline & WU-DO-030 & \multicolumn{2}{|c|}{ Fabiszewska E i wsp. Ocena parametrów obrazowania aparatury ultrasonograficznej } \\
\hline 18.00-18.10 & & & Przerwa kawowa \\
\hline \multirow{2}{*}{$18.10-20.30$} & \multicolumn{3}{|c|}{ Walne zebranie członków OZZFM } \\
\hline & \multicolumn{3}{|c|}{ Zwiedzanie W. Fizyki UAM oraz Poznańskiego Centrum Diagn. Obrazowej } \\
\hline \multirow[t]{2}{*}{ 21.00-24.00 } & \multirow{2}{*}{\multicolumn{3}{|c|}{ SOBOTA, o3 CZERWIEC 2017}} \\
\hline & & & \\
\hline $08.50-9.00$ & \multicolumn{3}{|c|}{ Spotkanie informacyjne dot. organizacji ćwiczeń } \\
\hline 09.00-10.00 & ĆWICZENIE 1 & Testy aparatów ultrasonograficznych & \multirow{4}{*}{$\begin{array}{r}\text { ćwiczenia odbywają się równolegle, grupy } \\
\text { max. po } 20 \text { osób }\end{array}$} \\
\hline 10.00-11.00 & ĆWICZENIE 2 & PTW & \\
\hline $11.00-12.00$ & ĆWICZENIE 3 & Health Technologies & \\
\hline $12.00-13.00$ & ĆWICZENIE 4 & Siemens & \\
\hline $13.00-13.15$ & \multicolumn{3}{|c|}{ Zakończenie konferencji } \\
\hline
\end{tabular}




\section{Wykaz plakatów elektronicznych}

\begin{tabular}{|c|c|}
\hline EP-NT-059 & ołodziejska Ż i wsp. Innowacyjne nośniki w terapii genowej - układy na bazie surfaktantów trigemini i lipidów \\
\hline EP-NT-06o & Trbaniak K i wsp. Wpływ promieniowania UV na generowanie wolnych rodników w układach nanocząstki-krew \\
\hline EP-NT-061 & $\begin{array}{l}\text { Gielnik M i wsp. Badania SAXS oraz dynamika konformacyjna amyloidogennej, nie ustrukturyzowanej } \\
\text { N-terminalnej domeny ludzkiego białka prionowego }\end{array}$ \\
\hline EP-NT-062 & $\begin{array}{l}\text { Gauza-Włodarczyk M i wsp. Pomiary impedancyjne zdrowej skóry ludzkiej poddane działaniu kolagenu } \\
\text { egzogennego }\end{array}$ \\
\hline EP-NT-063 & $\begin{array}{l}\text { Moliński A i wsp. Fulereny C6o jako środki kontrastujące - analiza strukturalna spektroskopowa } \\
\text { i toksykologiczna }\end{array}$ \\
\hline EP-NT-064 & $\begin{array}{l}\text { Pietralik Z i wsp. Proces oligomeryzacji i jego znaczenie w chorobach neurodegeneracyjnych na przykładzie } \\
\text { ludzkiej cystatyny C }\end{array}$ \\
\hline EP-NT-065 & $\begin{array}{l}\text { Zaręba J i wsp. Wpływ struktury surfaktantu na poziom dyspersji i toksyczność nanorurek węglowych } \\
\text { w kontekście ich potencjalnych zastosowań nanomedycznych }\end{array}$ \\
\hline EP-NT-066 & Haracz S, Kozak M. Wpływ surfaktantów gemini na morfologię nanowstążek złota \\
\hline EP-NT-067 & $\begin{array}{l}\text { Ludwiczak J i wsp. Wpływ surfaktantów dikationowych na strukturę drugorzędową wybranych peptydów: } \\
\text { N-terminalnego fragmentu ludzkiego białka prionowego i peptydu Ac-PEPTIDES- NH } 2\end{array}$ \\
\hline EP-NT-068 & $\begin{array}{l}\text { Dobosz B i wsp. Badanie metodą ESR funkcjonalizowanych nanocząstek magnetytu pod kątem ich zastosowania } \\
\text { w medycynie }\end{array}$ \\
\hline EP-BS-069 & Stieler O i wsp. Wykorzystanie tympanometrii szerokopasmowej w diagnostyce ucha środkowego \\
\hline EP-BS-070 & Romański P, Grajek M. Wyznaczenie normy wzrokowych potencjałów wywołanych \\
\hline EP-BS-071 & Majewska A i wsp. Wpływ zewnętrznego bodźca akustycznego na stabilność posturalną \\
\hline EP-BS-072 & Kawałkiewicz W i wsp. Wykorzystanie laserowej wibrometrii Dopplerowskiej do pomiaru drgań czaszki \\
\hline EP-OR-073 & $\begin{array}{l}\text { Michalska M i wsp. Ocena narażenia skóry i soczewek oczu na promieniowanie jonizujące na podstawie } \\
\text { pomiarów Laboratorium Dozymetrii Indywidualnej i Środowiskowej IFJ PAN. }\end{array}$ \\
\hline EP-OR-074 & $\begin{array}{l}\text { Kopeć R i wsp. Ocena indywidualnego równoważnika dawki na całe ciało Hp(10) w wybranych placówkach } \\
\text { wykorzystujących promieniowanie jonizujące w celach medycznych na podstawie pomiarów Laboratorium } \\
\text { Dozymetrii Indywidualnej i Środowiskowej IFJ PAN }\end{array}$ \\
\hline EP-OR-075 & Wiśniewska - Kubka S. Organizacja Zakładu Medycyny Nuklearnej - Pracownia Izotopowa klasy II \\
\hline EP-OR-076 & Marcinkowska-Gapińska A i wsp. Ochrona radiologiczna pacjenta stomatologii. \\
\hline EP-BT-077 & $\begin{array}{l}\text { Zemlik W i wsp. Parametryczna ocena rozkładów dawek uzyskanych śródtkankową brachyterapią HDR } \\
\text { w leczeniu uzupełniającym i radykalnym nowotworów zlokalizowanych w obrębie głowy i szyi }\end{array}$ \\
\hline EP-BT-078 & Dymnicka M i wsp. Raport ICRU 89 w praktyce \\
\hline EP-BT-079 & $\begin{array}{l}\text { Kabacińska R i wsp. Analiza zaleceń Raportu } 89 \text { ICRU "Prescribing, Recording and Reporting Brachytherapy for } \\
\text { Cancer of the Cervix" dotyczących specyfikacji i raportowania rozkładu dawki w brachyterapii raka szyjki macicy }\end{array}$ \\
\hline EP-BT-o80 & Nenko D i wsp. Leczenie wznowy w nowotworach regionu głowy i szyi \\
\hline EP-BT-081 & $\begin{array}{l}\text { Walczak J i wsp. Wprowadzenie techniki napromieniania raka stercza, metodą brachyterapii śródtkankowej, } \\
\text { w Dolnośląskim Centrum Onkologii }\end{array}$ \\
\hline EP-TT-082 & $\begin{array}{l}\text { Poncyliusz M i wsp. Analiza możliwości wprowadzenia adaptacyjnej metody napromieniania (ART) u chorych } \\
\text { z rakiem pęcherza moczowego pod kontrolą obrazową IGRT }\end{array}$ \\
\hline EP-TT-083 & $\begin{array}{l}\text { Borowska P i wsp. Weryfikacja stabilności wydajności akceleratorów medycznych za pomocą urządzenia } \\
\text { QuickCheck firmy PTW }\end{array}$ \\
\hline EP-TT-084 & $\begin{array}{l}\text { Kabat D i wsp. Fantom do testów geometrycznych konwencjonalnych symulatorów terapeutycznych oraz } \\
\text { medycznych akceleratorów liniowych wraz z wyposażeniem dodatkowym }\end{array}$ \\
\hline EP-TT-085 & Giżyńska M i wsp. Czy możliwe jest zwiększenie efektywności protokołu NAL przy zachowaniu nakładu pracy? \\
\hline EP-TT-086 & Sękowski P, Skwira-Chalot I. Promieniotwórczość wtórna tkanek po terapii hadronowej \\
\hline EP-TT-087 & $\begin{array}{l}\text { Tulik P i wsp. Odtwarzanie i przekazywanie jednostki dawki pochłoniętej w wodzie z wykorzysta } \\
\text { kalorymetru grafitowego }\end{array}$ \\
\hline
\end{tabular}




\begin{tabular}{|c|c|}
\hline EP-TT-088 & $\begin{array}{l}\text { Peszyńska-Piorun M i wsp. Kardiotoksyczność radioterapii u pacjentek po chirurgicznym leczeniu } \\
\text { oszczędzającym piersi lewej }\end{array}$ \\
\hline EP-TT-089 & Misiarz A i wsp. Akcelerator do Radioterapii Śródoperacyjnej - wyniki prac projektu Inta-Dose \\
\hline EP-TT-090 & Dąbrowski A i wsp. Analiza wyników weryfikacji jednostek monitorowych \\
\hline EP-TT-091 & $\begin{array}{l}\text { Skrobała A i wsp. Ocena nieinwazyjnego systemu pozycjonowania oka na radioterapię stereotaktyczną } \\
\text { nowotworów oczodołu napromienianych na aparacie CyberKnife }\end{array}$ \\
\hline EP-TT-093 & $\begin{array}{l}\text { Dąbrowska E i wsp. Zastosowanie druku 3D w radioterapii na przykładzie bolusa dedykowanego dla pacjenta } \\
\text { z nowotworem głowy i szyi }\end{array}$ \\
\hline EP-TT-094 & Ślusarczyk-Kacprzyk W i wsp. Wyniki zewnętrznego audytu dozymetrycznego TLD w radioterapii w 2016 roku \\
\hline EP-TT-095 & $\begin{array}{l}\text { Piotrowski T i wsp. Kiedy korekcja manualna zwiększa dokładność rejestracji obrazu podczas pozycjonowania } \\
\text { pacjentów z rakiem prostaty? }\end{array}$ \\
\hline EP-TT-096 & $\begin{array}{l}\text { Oborska-Kumaszyńska D. Wpływ parametrów skanowania i rekonstrukcji na jednostki Hounsfiled’a na } \\
\text { przykladzie systemu Philips Brilliance }\end{array}$ \\
\hline EP-TT-097 & $\begin{array}{l}\text { Siudziński T, Janiszewska M. Acuros XB } 13.6 \mathrm{w} \text { zastosowaniu radioterapii stereotaktycznej płuc w oparciu } \\
\text { o rekomendacje RTOG o813. Analiza przypadku }\end{array}$ \\
\hline EP-TT-098 & Raczkowski M, Janiszewska M. System nadzoru w dozymetrii \\
\hline EP-TT-099 & Walewska A i wsp. Weryfikacja dozymetryczna dawki obliczonej przez system planowania leczenia pod bolusem \\
\hline EP-TT-100 & $\begin{array}{l}\text { Porwoł P. Sprawdzenie poprawności automatycznej analizy parametrów kontroli jakości systemów obrazowania } \\
\text { używanych do weryfikacji teleradioterapii (IGRT) na przykładzie programu ARTISCAN }\end{array}$ \\
\hline EP-TT-101 & $\begin{array}{l}\text { Garbacz M, Skwira-Chalot I. Wpływ modulatora energii na rozkład dawki w radioterapii z użyciem wiązki } \\
\text { protonowej }\end{array}$ \\
\hline EP-TT-102 & Tumidajewicz M. Kontrola parametrów dynamicznych kolimatora Agility \\
\hline EP-TT-103 & Kuchcińska A. Teleradioterapia a narażenie kobiety w ciąży \\
\hline EP-TT-104 & $\begin{array}{l}\text { Nowakowski S i wsp. Wpływ zastosowanej metody napromieniania raka piersi na wielkość obszaru niskich dawek } \\
\text { (eIORT vs. 3D-CRT) }\end{array}$ \\
\hline EP-TT-105 & $\begin{array}{l}\text { Walewska A. Ocena komory jonizacyjnej Semiflex 3D (PTW) jako uniwersalnego detektora do pomiarów } \\
\text { względnych dawki dla wiązek wysokoenergetycznego promieniowania X z oraz bez filtra spłaszczającego }\end{array}$ \\
\hline EP-TT-106 & Winiecki J i wsp. Wpływ ułożenia rąk pacjenta na rozkład dawki u chorego leczonego metodą TBI \\
\hline EP-TT-107 & $\begin{array}{l}\text { Kopeć R i wsp. Pierwsza w Polsce radioterapia protonowa metodą wiązki skanującej w Centrum Cyklotronowym } \\
\text { Bronowice }\end{array}$ \\
\hline EP-TT-108 & $\begin{array}{l}\text { Kowalski A, Weselak M. Prosty model ilustrujący wynik pomiaru pola łukowego przy użyciu matrycy } \\
\text { dozymetrycznej }\end{array}$ \\
\hline EP-DO-109 & $\begin{array}{l}\text { Mazgaj P i wsp. Wartość diagnostyczna wybranych sekwencji rezonansu magnetycznego w obrazowaniu zmian } \\
\text { demielinizacyjnych w przebiegu stwardnienia rozsianego }\end{array}$ \\
\hline EP-DO-110 & $\begin{array}{l}\text { Baic A i wsp. Zastosowanie obrazowania termicznego do oceny efektów chirurgicznej dekompresji zespołu cieśni } \\
\text { nadgarstka }\end{array}$ \\
\hline EP-DO-111 & $\begin{array}{l}\text { Englisz B i wsp. Zastosowanie termografii i planimetrii w ocenie efektów tlenoterapii hiperbarycznej w leczeniu } \\
\text { owrzodzeń żylnych podudzi }\end{array}$ \\
\hline EP-DO-112 & $\begin{array}{l}\text { Tomaszuk M i wsp. Optymalizacja parametrów badania SPECT/CT scyntygrafii kośćca pod kątem narażenia } \\
\text { pacjenta na promieniowanie jonizujące }\end{array}$ \\
\hline EP-DO-113 & Oborska-Kumaszyńska D. Ocena ACS systemu tomograficznego (Philips Brilliance) \\
\hline EP-DO-114 & Grajek M. Grubość mięśni zewnątrzgałkowych a praca w bliży. \\
\hline EP-DO-115 & Bębas E i wsp. Analiza tekstury obrazów radiologicznych RVG w procesie gojenia po utracie masy kostnej \\
\hline EP-DO-116 & $\begin{array}{l}\text { Boś-Liedke A i wsp. Ocena zastosowania PTMTC jako sensora natlenienia do multimodalnego obrazowania in } \\
\text { vivo }\end{array}$ \\
\hline EP-DO-117 & $\begin{array}{l}\text { Kuchcińska A. Diagnostyka obrazowa przy wykorzystaniu metod medycyny nuklearnej a narażenie kobiety } \\
\text { w ciąży }\end{array}$ \\
\hline EP-DO-118 & Kuchcińska A. Bezpieczeństwo pacjenta i personelu w procedurach Magnetycznego Rezonansu Jądrowego \\
\hline
\end{tabular}




\title{
WYKŁADY EDUKACYJNE I WYSTĄPIENIA USTNE
}

\section{Wykłady edukacyjne: Nanotechnologia w medycynie [WE-NT]}

\author{
WE-NT-001: Nanotechnologia w medycynie \\ Henryk Figiel ${ }^{1}$ \\ (1) Wydziat Fizyki i Informatyki Stosowanej, Akademia Górniczo-Hutnicza w Krakowie, Kraków, Polska
}

\author{
[Brak streszczenia]
}

\section{Wystąpienia ustne: Nanotechnologia [WU-NT]}

\author{
WU-NT-002 [Praca nagrodzona]: Zastosowanie magnetycznych nanocząstek typu rdzeń/powłoka \\ do obrazowania molekularnego guzów mózgu \\ Barbara Blasiak ${ }^{1,2}$, Frank C. J. M. Van Veggel ${ }^{3}$, Władyslaw Węglarz ${ }^{1}$, John Matyas², Dragana Ponjevid², \\ Garnette R. Sutherland ${ }^{2}$, Bogusław Tomanek ${ }^{1,4}$ \\ (1) Instytut Fizyki Jądrowej im. Henryka Niewodniczańskiego Polskiej Adakemii Nauk w Krakowie, Polska \\ (2) Department of Clinical Neurosciences, University of Calgary, Canada \\ (3) Department of Chemistry, University of Victoria, Victoria, British Columbia, Canada \\ (4) Department of Oncology, University of Alberta, Edmonton, Canada
}

WPROWADZENIE: Celem pracy było stworzenie celowanego środka kontrastowego do obrazowania molekularnego rezonansem magnetycznym (RM) glejaka. Środek zawiera magnetyczne nanocząstki typu rdzeń/powłoka wraz z dołączonymi do nich przeciwciałami charakterystycznymi dla tego nowotworu.

MATERIAŁ I METODA: Glejaki zaliczane są do jednych z najgroźniejszych guzów mózgu. Średni czas życia po zdiagnozownaniu na ten rodzaj guza to niecały rok. Okres ten nie uległ zmianie przez ostatnie 30 lat. Wczesne rozpoznanie guza, jego lokalizacji i wielkości mogłoby umożliwić pozytywne rokowanie. Obecnie diagoza bazuje zwykle na obrazie (CT lub RM). Niestety, obrazy te nie uwidaczniają małych guzów i zazwyczaj zaniżają ich rzeczywistą wielkość przez co usunięcie nowotworu nie jest całkowite, co w konsekwencji prowadzi do ponownej operacji. Dlatego opracowanie nowego środka kontrastowego do obrazowania rezonansowego guza mózgu jest niezbędne. Stosowane obecnie środki kontrastowe (np. GdDTPA lub $\mathrm{Fe}_{3} \mathrm{O} 4$ ) wykorzystywane do poprawy obrazu guza, nie są optymalne.

WYNIKI: Magnetyczne nanocząstki typu rdzeń/otoczka zostały wyprodukowane. Ich własności magnetyczne zostały zmierzone przy pomocy metody SQUID a czasy relaksacji w polach 9.4T oraz $3 \mathrm{~T}$ przy zastosowaniu metody echa spinowego i dopasowaniu mono-eksponencjalnym. Dzięki magnetycznym i bio-chemicznym własnościwościom wyprodukowane nanocząstki mogą zastąpić obecnie używane środki bazujące na jonach gadolinu ( $\mathrm{Gd}_{3}+$ ). Nanocząstki te mają kilka zalet w stosunku do kontrastu na bazie Gd3+, który skraca praktycznie tylko czas T1. Ich bardzo duże momenty magnetyczne czynią z nich efektywne "wzmacniacze" relaksacji T1 oraz T2 pozwalając zastosować je w niskich, a więc nieszkodliwych dla zdrowia stężeniach do obserwacji próbek lub tkanek patologicznych, w których się akumulują. Ich własności chemiczne pozwalają na syntezę (tzw. funkcjonalizację) z przeciwciałami nacelowanymi na nowotwory. Użyte jako środki kontrastowe nanocząstki wstrzykiwane są do układu krwionośnego i razem z krwią dostają się do różnych organów, w szczególności do guzów, dzięki specyficznym dla nich przeciwciałom lub białkom.

WNIOSKI: Proponowany celowany środek kontrastowy typu rdzeń/powłoka z dołączonym przeciwciałem pozwala na jednoczesne skrócenie czasów relaksacji T1 oraz T2, i umożliwia pozytywny i swoisty obraz glejaka. 
WU-NT-003: Nanokompozytowe membrany włókniste - możliwości zastosowań medycznych Ewa Stodolak-Zych ${ }^{\mathbf{1}}$, Magdalena Kocot ${ }^{2}$, Marta Juszczak ${ }^{3}$, Maciej Boguń ${ }^{4}$

(1) Wydziat Inżynierii Materiałowej i Ceramiki, Akademia Górniczo-Hutnicza, Kraków, Polska

(2) Wydziat Elektroniki, Informatyki, Automatyki i Inżynierii Biomedycznej, Kraków, Polska

(3) Wydział Inżynierii Materiałowej i Ceramiki, Akademia Górniczo-Hutnicza, Kraków, Polska

(4) Wydział Technologii Materiałowych i Wzornictwa Tekstyliów, Politechnika Łódzka, Łódź, Polska

WPROWADZENIE: Membrany porowate to interesująca grupa podłoży, których zastosowanie obejmuje inżynierię tkankowa i medycynę regeneracyjną. Spośród wielu metod stosowanych do wytwarzania membran porowatych są i te pozwalające na formowanie włókien mikrometrycznych (np. ze stopu lub roztworu) i nanowłókien (np. elektrospinning). Jeśli na etapie formowania do matrycy polimerowej wprowadzone zostaną nanaometryczne cząstki to tworzywo takie zyskuje szereg nowych właściwości a co za tym idzie większe spektrum aplikacji. Z punktu widzenia medycznego są to większe ubytki kostne wynikające z resekcji cyst czy zmian ponowotworowych.

Celem pracy było otrzymanie i zbadanie nanokompzytowych włókien węglowych (CNF), polilaktydowych (PLA) i alginanowych (CA), które modyfikowano cząstkami ceramicznymi (TCP/HAp, SiO2). Zakładano, ze membrana włóknista przez obecność bioaktywnych modyfikatorów będzie stanowiła czynnik stymulujący komórki do szybszej adhezji i proliferacji w obrębie ubytku kostnego a tym samym regeneracji uszkodzenia w obrębie kości. Wybraną grupę membran (CA) poddano dodatkowej modyfikacji: oprócz bioaktywnego napełniacza wprowadzony został magnetyt (Fe3O4). Celem tego zabiegu była chęć monitorowania procesu kościotworzenia i degradacji biopolimerowego podłoża w warunkach in vivo.

MATERIAŁ I METODA: Dzięki zastosowanym metodom badawczym określono wpływ cząstki na: łańcuch polimerowy (FTIR-ATR), morfologię włókien (SEM), trwałość w warunkach in vitro a także potencjał bioaktywny (SEM-EDS). W przypadku membran nodyfikowanych magnetytem wykonano wstępne badania MRI.

WYNIKI: Dowiedziono, że obecność ceramicznych nanocząstek w matrycy polimerowej i węglowej indukuje bioaktywnośc materiału, a także poprawia jego biozgodność. Żaden z badanych materiałów nie jest cytotoksyczny (badania z udziałem komórek NHost). W warunkach in vitro (symulowane osocze (SBF)/37oC) na powierzchni włókien obserwuje się nukleację apatytu (SEM/EDS). Warunkiem koniecznym jest tutaj uzyskanie homogennego rozmieszczenia nanocząstek we włóknie, które w nieznaczny sposób zwiększają średnicę włókna. Nanonapełniacz reguluje również trwałość materiałów biodegradowalnych, obniżając ją gdyż cząstka stanowi swoisty obszar gromadzący wodę. W zależności od rodzaju osnowy można spodziewać się skrócenia czasu degradacji o ok 30\%.

WNIOSKI: Przedstawione wyniki badań wskazują, że: niezależnie od użytego polimeru (PLA, CA, PAN), metody formowania membrany nanokompozytowej (z nanowłókien, mikrowłókien) możliwe jest sterowanie szeregiem właściwości użytkowych tworzywa: od właściwości mechanicznych, fizykochemicznych, biologicznych po możliwość monitorowania zachowania materiału w warunkach in vivo z wykorzystaniem metod obrazowania medycznego.

WU-NT-004: Samoorganizujące się układy polimerowe jako nośniki piroksykamu Dorota Lachowicz' ${ }^{1}$, Kaczyńska ${ }^{2}$, A Kmita ${ }^{1}$, A Karewicz², M Nowakowska², S Zapotoczny²

(1) AGH w Krakowie, Akademickie Centrum Materiałów i Nanotechnologii, Kraków, Polska

(2) Uniwersytet Jagielloński w Krakowie, Kraków, Polska

WPROWADZENIE: Głównym celem badań było opracowanie układu polimerowego, w formie nanoagregatów polisacharydowych, zdolnego do efektywnego transportu leku - piroksykamu. Układ ten jest przykładem nośnika nowego typu dedykowanego do leków o niskiej rozpuszczalności w wodzie i płynach fizjologicznych. W ramach prac zsyntetyzowano nowe kationowe i anionowe pochodne polisacharydów na bazie hydroksypropylocelulozy i kurdlanu oraz wykonano ich charakterystykę fizykochemiczną. W badaniach wykorzystano unikalne właściwości wybranych modyfikowanych polisacharydów do tworzenia nanoagregatów polimerowych na drodze samoorganizacji w wyniku wzajemnego oddziaływania dwóch 
polielektrolitów (polikation - polianion).

MATERIAŁ I METODA:

Materiał:

- Kationowa pochodna kurdlanu uzyskana w wyniku reakcji grup -OH kurdlanu z chlorkiem glicydylotrimetyloamoniowym (CUR-GTMAC)

- Anionowo modyfikowana hydroksypropyloceluloza (HPC-SSS), otrzymana poprzez naszczepienie (grafting) p-styrenosulfonianu sodu (SSS) na łańcuchu HPC

- Nanocząstki uzyskane w wyniku samoorganizacji polielektrolitów

- Piroksykam

Metody badawcze:

- Rozmiar i potencjał powierzchniowy otrzymanych nośników określono metodą dynamicznego rozpraszania światła (DLS) z wykorzystaniem aparatu Malvern Nano-ZS (Malvern Instrument Ltd.).

- Morfologia uzyskanych struktur została zobrazowana techniką skaningowej mikroskopii elektronowej SEM (Versa 3D, FEI) oraz mikroskopii sił atomowych AFM (AFM Bruker Dimension ICON).

WYNIKI: W początkowym etapie badań potwierdzono znaczne powinowactwo piroksykamu do anionowej pochodnej hydroksypropylocelulozy (HPC-SSS) wyznaczając stałą przyłączania anionowa hydroksypropyloceluloza-piroksykam techniką miareczkowania spektrofotometrycznego (uzyskana stała przyłączania $\mathrm{Ka}=103 \mathrm{dm} 3 \times$ mol-1).). Nanoczstki polimerowe zawierajce piroksykam (NP-PIX) zostaBy przygotowany przy ulyciu anionowej pochodnej hydroksypropylocelulozy (HPC-SSS) oraz kationowo modyfikowanego kurdlanu (CUR-GTM) na drodze samoorganizacji w wyniku oddziaBywaD elektrostatycznych polikation-polianion. Uzyskano gBadkie, kuliste obiekty o wielko[ci ok. 160-300 nm, co potwierdziBy obrazy otrzymane z zastosowaniem mikroskopii SEM i AFM. Otrzymane struktury cechuj si znacznym ujemnym potencjaBem zeta, co [wiadczy o ich koloidalnej stabilno[ci. Dokonano analizy wielko[ci i potencjaBu zeta wybranego ukBadu nanosfer(1:25), w ró|nych temperaturach.

WNIOSKI: W niniejszej pracy opracowano nową metodę otrzymywania nanocząstek polimerowych na drodze samoorganizacji w wyniku oddziaływań elektrostatycznych pomiędzy dwoma modyfikowanymi polisacharydami o przeciwnych ładunkach. Opisana metoda otrzymywania nanośników polisacharydowych pozwala w prosty i szybki sposób uzyskać sferyczne, stabilne cząstki o nanometrycznym rozmiarze. Stwierdzono, że zarówno wielkość nanocząstek jak i ich potencjał powierzchniowy mogą być kontrolowane poprzez odpowiedni dobór ilości polielektrolitów w mieszaninie syntetycznej. Opracowano metodykę zamykania piroksykamu w utworzonych nanocząstkach NPs, w której wykorzystano wysokie powinowactwo anionowej pochodnej HPC do piroksykamu Zaobserwowano, żew podwyższonych temperaturach nanocząstki zwiększają średnicę hydrodynamiczną od $255 \mathrm{~nm} \mathrm{w}$ temperaturze $25^{\circ} \mathrm{C}$ do $401 \mathrm{~nm} \mathrm{w}$ temperaturze $45^{\circ}$ C. Zarejestrowano również wpływ temperatury na gęstość optyczną zawiesiny nanocząstek, co potwierdza termoczułość utworzonych nanoukładów. Celem dalszych badań będzie charakterystyka biologiczna uzyskanych nośników pod kątem ich toksyczności i efektywności transportu piroksykamu do komórek.

(Projekt realizowany w ramach projektu SONATA $8 \mathrm{nr}$ UMO-2014/15/D/ST4/O2770 finansowanego przez Narodowe Centrum Nauki)

WU-NT-005: Nanocząstki ferrytu manganu do potencjalnych zastosowań w hipertermii magnetycznej

Angelika Kmita1 ${ }^{1}$, Marta Stolińska² ${ }^{2}$ Antoni Żywczak ${ }^{1}$, Dorota Lachowicz ${ }^{1}$, Katarzyna Nowicka ${ }^{3}$, Henryk Figiel $^{4}$, Marcin Sikora ${ }^{1}$

(1) AGH w Krakowie, Akademickie Centrum Materiałów i Nanotechnologii, Kraków, Polska

(2) AGH w Krakowie, Wydział Inżynierii Mechanicznej i Robotyki, Kraków, Polska 
(3) AGH w Krakowie, Wydział Inżynierii Materiałowej i Ceramiki, Kraków, Polska

(4) AGH w Krakowie, Wydział Fizyki i Informatyki Stosowanej, Kraków, Polska

WPROWADZENIE: Celem przeprowadzonych badań było określenie możliwości wykorzystania wodnych roztworów nanocząstek ferrytu manganu ( $\mathrm{MnFe2O} 4)$ w otoczce polimerowej z alginianu sodu (NaAlg) do zastosowań w hipertermii magnetycznej. W badaniach wykorzystano roztwory nanocząstek ferrytu manganu o stężeniu: 0,5 oraz $1 \%$. Efekt hipertermiczny rozpatrywanych nanocząstek magnetycznych badano z wykorzystaniem aparatu do indukcyjnego nagrzewania roztworów nanocząstek, który znajduje się Akademickim Centrum Materiałów i Nanotechnologii AGH. Określono temperaturę nagrzewania się wodnych roztworów nanocząstek w zależności od stężenia oraz stosowanego natężenia prądu indukującego pole elektromagnetyczne wynoszącego odpowiednio: 225 oraz 250 A. Dodatkowo wykonano pomiary magnetyczne nanocząstek ferrytu manganu z wykorzystaniem magnetometru wibracyjnego (VSM) w temperaturze pokojowej w funkcji zewnętrznego pola magnetycznego (-1,5 do 1,5 T).

\title{
MATERIAŁ I METODA:
}

Materiały:

Nanocząstki ferrytu manganu ( $\mathrm{MnFe2O}$ ) w otoczce polimerowej z alginianu sodu.

Stężenie nanocząstek w badanych roztworach wynosiło odpowiednio: 0,5 oraz $1 \%$.

Metody badawcze:

- Efekt hipertermiczny rozpatrywanych próbek badano z wykorzystaniem aparatu do indukcyjnego nagrzewania roztworów nanocząstek firmy Dacpol.

- Właściwości magnetyczne nanocząstek ferrytu manganu w otoczce polimerowej określono za pomocą magnetometru wibracyjnego typ 7407 firmy LakeShore.

WYNIKI: Roztwory nanocząstkek ferrytu manganu o stężeniu o,5 \% w otoczce alginianu sodu osiągały temperaturę 42,5 oC po ok 320 sek. (przy natężeniu stosowanego prądu wnoszącego 225A) oraz po ok. 275 sek. (przy natężeniu 250 A). Natomiast roztwory o wyższym stężeniu nanocząstek to jest 1 \% osiągały zakładaną temperaturę 42,5 oC nieco szybciej odpowiednio po: 220 sek. (przy natężeniu

250 A) oraz po ok. 200 sek. (dla 250 A). W trakcie pomiarów właściwości magnetycznych w temperaturze otoczenia zarejestrowano pętle histerezy. Namagnesowanie nasycenia badanych nanocząstek ferrytu manganu w alginianie sodu wynosiło ok. 2,95 [emu /g].

WNIOSKI: Stężenie nanocząstek ferrytu manganu (MnFe2O4) wpływa na szybkość nagrzewania się roztworu. Im wyższe stężenie tym czas osiągnięcia zakładanej temperatury jest krótszy.

Istnieje optymalne natężenie prądu, przy którym uzyskuje się zakładaną temperaturę roztworu $(42,50 \mathrm{C})$ najniższym kosztem, które wynosi 225 A dla geometrii eksperymentu.

Celem dalszych badań będzie systematyczna charakterystyka roztworów nanocząstek ferrytu manganu typu $\mathrm{MnFe2O} 4 / \mathrm{NaAlg} \mathrm{w}$ aspekcie ich potencjalnego wykorzystania w metodzie hipertermii.

(Praca wykonana w ramach grantu SONATA BIS nr 2014/14/E/ST3/ooo26 finansowanego przez Narodowe Centrum Nauki).

\section{Wykłady edukacyjne: Biosygnały [WE-BS]}

\author{
WE-BS-006: Elektrokardiografia i pulsoksymetria wysokiej rozdzielczości sygnałowej \\ w diagnostyce medycznej \\ Ryszard Krzyminiewski ${ }^{1}$, Bernadeta Dobosz ${ }^{1}$
}

(1) Zakład Fizyki Medycznej, Wydział Fizyki UAM, Poznań, Polska

WPROWADZENIE: Celem pracy jest pokazanie nowych metod diagnostycznych chorób układu krążenia: elektrokardiografii wysokiej rozdzielczości sygnałowej NURSE-ECG i pulsoksymetrii wysokiej rozdzielczości sygnałowej HSR Pulsoksymetria 
MATERIAŁ I METODA: Choroby układu krążenia obok chorób nowotworowych są największym problemem współczesnej cywilizacji. Podstawową, standardowo stosowaną w diagnostyce medycznej metodą badania serca jest elektrokardiografia. Przy jej pomocy można wykryć zmiany niedokrwienne lub/i zaburzenia przewodzenia w sercu. Niestety w 50\% przypadków standardowe EKG nie wykazuje zmian charakterystycznych dla zawału mięśnia sercowego. Z pomocą przychodzi nowa metoda diagnostyki serca elektrokardiografia wysokiej rozdzielczości sygnałowej (NURSE-ECG). Stosując tę metodę można wykryć niewidoczne w standardowym elektrokardiogramie stosunkowo niewielkie zmiany w aktywności elektrycznej poszczególnych fragmentów mięśnia sercowego spowodowane np. niedokrwieniem, wpływem leku, przebytym zawałem itp. Z kolei pulsoksymetria to nieinwazyjna metoda umożliwiająca monitorowanie tętna oraz wysycenia krwi tlenem. Standardowo stosowana jest głównie na oddziałach intensywnej opieki medycznej do monitorowania pacjentów. Niestety nie jest tu brana pod uwagę analiza fali pulsu, która niesie w sobie wiele cennych informacji o stanie układu krążenia. Dlatego opracowano pulsoksymetrię wysokiej rozdzielczości sygnałowej (HSR-PW), nową metodę pozwalającą w bardzo precyzyjny sposób ocenić takie parametry układu krążenia jak: rytm, wysycenie tlenem, funkcjonowanie lewej komory serca, aorty, zastawek serca oraz obecność zmian miażdżycowych.

WYNIKI: Zbadano tysiące pacjentów z różnymi chorobami układu krążenia metodą NURSE-ECG i HSR Pulsoksymetrii. Porównano uzyskane wyniki ze standardowymi metodami diagnostycznymi takimi jak standardowe EKG, echokardiografia, koronarografia, SPECT stwierdzając wysoką czułość i specyficzność tych nowych metod.

WNIOSKI: Metoda NURSE-ECG i HSR Pulsoksymetria wykazują dużą przydatność w diagnostyce zmian układu krążenia.

WE-BS-007: Protetyka słuchu

Dorota Hojan-Jezierska ${ }^{1}$

(1) Zakład Protetyki Stuchu Katedry Biofizyki, Uniwersytet Medyczny im. Karola Marcinkowskiego w Poznaniu, Polska

\title{
[Brak streszczenia]
}

\section{Wystąpienia ustne: Biosygnały [WU-BS]}

\author{
WU-BS-008 [Praca nagrodzona]: Perspektywy zastosowania interfejs mózg-komputer \\ w inżynierii biomedycznej \\ Dariusz Man ${ }^{1}$, Ryszard Olchawa ${ }^{1}$
}

(1) Instytut Fizyki, Uniwersytet Opolski, Opole, Polska

WPROWADZENIE: W ostatnich latach możemy zaobserwować szybki rozwój techniki cyfrowej, wykorzystującej prądy czynnościowe mózgu. Technologiczne wsparcie neurofizjologii, umożliwiło stosunkowo prostą rejestrację fal mózgowych, co w konsekwencji doprowadziło do budowy zintegrowanych interfejsów BCI (Brain Computer Interface) [1,2], wykorzystywanych np. w zestawach do biofeedbacku EEG. Technologia ta znalazła również zastosowanie do zarządzania odpowiednio przygotowanymi aplikacjami, działającymi na komputerach PC, smartfonach i tabletach. Możliwe jest również zastosowanie tej technologii do sterowanie urządzeniami elektronicznymi zarówno powszechnego użytku, jak i zawansowanymi technicznie, przez osoby z najpoważniejszymi deficytami neurologicznymi. Ma to istotne znaczenie w procesie rehabilitacji i poprawie jakości życia takich osób. Potencjał technologii BCI w biocybernetyce i inżynierii biomedycznej jest nie do przecenienia. Naszym celem było znalezienie odpowiedzi na pytanie, czy istnieją skuteczne i tanie sposoby zastosowania technologii BCI, do sterowania urządzeniami i aplikacjami wspierającymi osoby z dużymi dysfunkcjami ruchu.

MATERIAŁ I METODA: W badaniach zastosowaliśmy zestawy umożliwiające mapowanie prądów czynnościowych mózgu, dające możliwość monitorowania i zapisu pełnego obrazu EEG. Zastosowane 
urządzenia składały się z 14 kanałowego hełmu ( AF3, F7, F3, FC5, T7, P7, O1, O2, P8, T8, FC6, F4, F8, AF4 ) z dwiema elektrodami odniesienia ( $\mathrm{P}_{3}$ / P4) w konfiguracji CMS / DRL, interfejsu BIC i oprogramowania na komputer PC. Podstawowe parametry układu pomiarowego użytego w badaniach: częstotliwość próbkowania 128 lub 256 SPS, rozdzielczość 14 lub 16 bitów, wbudowany 5 rzędowy filtr Sinc. W celu wyłowienia charakterystycznych impulsów EEG, badaniom poddano 20 osób (10 mężczyzn i 10 kobiet) w różnym wieku (od 22 do 85 lat). Podczas badania zastosowano specjalny algorytm, umożliwiający precyzyjne określenie odpowiedzi mózgu na zadane czynności psychomotoryczne.

WYNIKI: Analiza sygnałów pokazała istnienie silnych, charakterystycznych impulsów elektrycznych, zlokalizowanych w ściśle określonych rejonach mózgu. Kształt i amplituda impulsów była zbliżona w każdym przebadanym przypadku.

WNIOSKI: Wyniki takie wskazują na możliwości stworzenia uniwersalnego algorytmu do sterowania urządzeniami technicznymi i aplikacjami na komputery PC i urządzenia mobilne, współpracującego z szeroką grupą użytkowników.

\title{
Wykłady edukacyjne: Ochrona radiologiczna [WE-OR]
}

\author{
WE-OR-010: Ochrona radiologiczna w radioterapii śródoperacyjnej Intrabeam PRS-500 \\ Mirosław Lewocki ${ }^{1}$, Magdalena Lukowiak ${ }^{1}$, Michał Falco ${ }^{2}$ \\ (1) Zakład Fizyki Medycznej, Zachodniopomorskie Centrum Onkologii w Szczecinie, Polska \\ (2) Zakład Radioterapii, Zachodniopomorskie Centrum Onkologii w Szczecinie, Polska
}

\section{[Brak streszczenia]}

WE-OR-011: Termoluminescencja i wykorzystanie jej w dozymetrii indywidualnej, środowiskowej i klinicznej promieniowania jonizującego.

Maciej Budzanowski ${ }^{1}$

(1) Instytut Fizyki Jądrowej im. H. Niewodniczańskiego Polskiej Akademï Nauk, Kraków, Polska

\section{[Brak streszczenia]}

\section{Wystąpienia ustne: Ochrona Radiologiczna [WU-OR]}

\author{
WU-OR-012 [Praca nagrodzona]: Badanie pól promieniowania mieszanego wokół medycznego \\ akceleratora liniowego

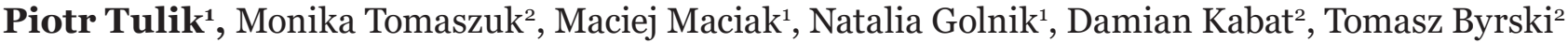 \\ (1) Instytut Metrologii i Inżynierii Biomedycznej, Wydział Mechatroniki, Politechnika Warszawska, Polska \\ (2) Centrum Onkologii Instytut im. Marii Skłodowskiej-Curie Oddział w Krakowie, Kraków, Polska
}

WPROWADZENIE: Ze względu na powstające wtórne promieniowanie jonizujące, istotnym zagadnieniem z punktu widzenia ochrony radiologicznej w teleradioterapii jest wyznaczanie dokładnego rozkładu pól promieniowania w otoczeniu głowicy akceleratora. Znajomość rozkładu pól promieniowania mieszanego (w tym znajomość składowych dawki od promieniowania gamma i neutronów oraz wskaźnika jakości promieniowania) pozwala oszacować narażenie pacjentów oraz personelu medycznego podczas przeprowadzania terapii.

Przeprowadzone w ramach niniejszej pracy badania miały na celu określenie dawki całkowitej oraz jej składowych w zależności od konfiguracji układu kształtowania wiązki i energii fotonów oraz ocenę mocy dawki pochodzącej od aktywacji materiałów głowicy akceleratora. 
MATERIAŁ I METODA: Pomiary wykonano wokół medycznego akceleratora liniowego typu Clinac 230oC/D (Varian) przy położeniu ramienia $\mathrm{O}^{\circ}$ i kącie kolimatora $\mathrm{O}^{\circ}$. Jako detektory wykorzystano rekombinacyjną komorę jonizacyjną REM2 równoważną tkance miękkiej (pomiar dawki całkowitej, składowej gamma, składowej neutronowej, rekombinacyjnego wskaźnika jakości promieniowania) oraz komorę bezwodorową GW2 (składowa gamma). Do analizy wyników użyto metod rekombinacyjnych oraz metody dwudetektorowej.

Detektory umieszczano w następujących punktach pomiarowych: $0^{\circ}$ (w osi długiej stołu terapeutycznego), $90^{\circ}$ i $270^{\circ}$, w odległości $100 \mathrm{~cm}$ od osi wiązki, na wysokości głowicy akceleratora oraz na wysokości izocentrum akceleratora. Dodatkowo na wysokości izocentrum, komory zostały umieszczone w odległości $50 \mathrm{~cm}$ od osi wiązki w osi długiej stołu terapeutycznego $\left(0^{\circ}\right.$ oraz $\left.180^{\circ}\right)$.

Badania przeprowadzono dla 7 różnych konfiguracji układu kształtowania wiązki: pola maksymalnego $40 \times 40 \mathrm{~cm} 2$, referencyjnego $10 \times 10 \mathrm{~cm} 2 \mathrm{z}$ układem listków kolimatora wielolistkowego MLC całkowicie otwartym lub zamkniętym, pola 0,5xo,5 cm2, 0,5x40 cm2, 40xo,5 cm2 z układem listków MLC całkowicie otwartym. Pomiary przeprowadzono w każdej konfiguracji toru dla wiązek o efektywnych potencjałach przyspieszających: $6 \mathrm{MV}$ i $18 \mathrm{MV}$.

WYNIKI: Na podstawie wykonanych pomiarów wyznaczono rekombinacyjny wskaźnik jakości promieniowania (Q4), dawkę całkowitą DC*(10) oraz składową gamma i neutronową dla każdej z konfiguracji układu kształtowania wiązki. Dalej oszacowano wartość przestrzennego równoważnika dawki $\mathrm{H}^{*}(10)$ jako miary narażenia na promieniowania jonizujące w pomieszczeniu terapeutycznym. Dodatkowo oszacowano moc dawki pochodzącą od aktywacji elementów głowicy akceleratora.

WNIOSKI: Praca pozwoliła na przeprowadzenie kompleksowej analizy rozkładu pól promieniowania mieszanego wokół akceleratora liniowego, w tym wyznaczenie udziału poszczególnych składowych promieniowania wtórnego gamma i neutronów w $\mathrm{H}^{*}$ (10) (poza polem terapeutycznym), a także potencjalnego narażenia w wyniku aktywacji elementów głowicy akceleratora liniowego.

\title{
Wykłady edukacyjne: Brachyterapia [WE-BT]
}

\author{
WE-BT-013: Planowanie i optymalizacja brachyterapii \\ Grzegorz Zwierzchowski ${ }^{1,2}$ \\ (1) Katedra i Zakład Elektroradiologii, WNoZ, UM w Poznaniu, Poznań, Polska \\ (2) Zakład Fizyki Medycznej, Wielkopolskie Centrum Onkologii, Poznań, Polska
}

\section{[Brak streszczenia]}

\section{Wystąpienia ustne: Brachyterapia [WU-BT]}

\author{
WU-BT-014 [Praca nagrodzona]: Zastosowanie filmów radiochromowych w procedurach \\ weryfikacji systemów planowania leczenia w brachyterapii. \\ Grzegorz Bielęda ${ }^{1,2}$, Grzegorz Zwierzchowski ${ }^{1,2}$ \\ (1) Wielkopolskie Centrum Onkologii, Poznań, Polska \\ (2) Katedra i Zakład Elektroradiologii, Uniwersytet Medyczny w Poznaniu, Polska
}

WPROWADZENIE: Celem tego badania było określenie przydatności weryfikacji dozymetrycznej algorytmu obliczeniowego stosowanego w systemie planowania leczenia (TPS) dla pojedynczych pozycji postoju źródła i dla planów leczenia z zastosowaniem aplikatorów ginekologicznych.

MATERIAŁ I METODA: Filmy dozymetryczne GAFCHROMIC EBT skalibrowano przy użyciu 14 arkuszy filmu stosując dawki od o,25 Gy do 8,o Gy z wykorzystaniem źródła HDR Ir-192. Zebrano dane dla pojedynczej pozycji postoju źródła na różnych głębokościach w fantomie wodnym, dla trzech ortogonalnych płaszczyzn 
w stosunku do osi źródła promieniotwórczego. Dodatkowo w fantomie wodnym wykorzystano standardowe cylindry dopochwowe o trzech średnicach. Pomiary wykonano dla aplikatorów bez osłony i trzech kombinacji osłon. Kolejnym krokiem było zbadanie rozkładów dawek dla aplikatorów pierścieniowych o średnicy 26 i $30 \mathrm{~mm}$ z sondą o długości $60 \mathrm{~mm}$ zagiętą pod kątem $60^{\circ}$. Zmierzone rozkłady dawki zostały porównane z obliczonymi przy użyciu systemu planowania leczenia. Obliczanie dawki zostało przeprowadzone zgodnie z raportem TG43 AAPM. W celu porównania dwóch obrazów przedstawiających dawkę pochłoniętą (mierzoną i planowaną) zastosowano analizę gamma (3\%, $3 \mathrm{~mm})$.

WYNIKI: Dla pojedynczej pozycji postoju źródła rozkłady dawek zmierzonych i odpowiadających im dawek z TPS wykazano, że w pewnym zakresie dawek rozkład dawki wokół źródła można mierzyć stosując filmy radiochromowe. Kilka obszarów obrazów wykazało odchylenia od kryteriów akceptacji, głównie z powodu uszkodzenia filmów. Dla wszystkich zastosowanych walców o różnych średnicach i dla wszystkich osłon przeprowadzono analizę gamma i wykazano, że ponad 90\% analizowanych punktów spełnia kryteria gamma (3\%, $3 \mathrm{~mm})$. Dla aplikatorów pierścieniowych o średnicy $26 \mathrm{~mm}$ i $30 \mathrm{~mm}$ średnia gamma wahała się odpowiednio od 0,1 do 0,44 i od o,1 do 0,27. W obu przypadkach 99\% mierzonych punktów odpowiadało dawkom obliczonym przez TPS.

WNIOSKI: Analiza gamma wykazała bardzo dobrą zgodność pomiędzy rozkładami dawki obliczonymi w TPS i zmierzonymi filmami radiochromowymi, wykazując w ten sposób przydatność stosowania dozymetrii filmowej w brachyterapii.

\author{
WU-BT-015: Analiza rozkładu dawki dla aplikacji dojamowo-śródtkankowych w brachyterapii \\ raka szyjki macicy. \\ Judyta Wiercińska ${ }^{1,2}$, Renata Kabacińska ${ }^{1}$, Tomasz Skawiński ${ }^{1}$, Roman Makarewicz ${ }^{2,3}$ \\ (1) Zakład Fizyki Medycznej, Centrum Onkologii w Bydgoszczy, Polska \\ (2) Katedra i Klinika Onkologii i Brachyterapii, Collegium Medicum w Bydgoszczy, UMK w Toruniu, Polska \\ (3) Oddział Kliniczny Brachyterapii, Centrum Onkologii w Bydgoszczy, Polska
}

WPROWADZENIE: Celem pracy jest analiza rozkładu dawki dla aplikacji dojamowo-śródtkankowych w brachyterapii raka szyjki macicy z wykorzystaniem aplikatora Vienna (sonda domaciczna, aplikator typu ring z dodatkowymi otworami pozwalającymi na aplikację igieł).

MATERIAŁ I METODA: Przeanalizowano 31 rzeczywistych planów leczenia z wykorzystaniem aplikatora Vienna (TRN plans - tandem/ring/needles) chorych leczonych w ciągu ostatnich 2 lat. Pacjentki leczone były metodą HDR z dawką frakcyjną 7.5Gy. Wśród wszystkich aplikacji dojamowo-śródtkankowych 12 chorych leczono z wykorzystaniem specjalnie wygiętych igieł wiedeńskich umieszczonych w otworach ringu, a w przypadku 19 aplikacji igły implantowano „z wolnej ręki” wewnątrz aplikatora typu ring. Do każdego rzeczywistego planu leczenia stworzono wirtualny plan nieuwzględniający zaaplikowanych igieł (TR plans - tandem/ring). Porównano parametry dozymetryczne obydwu planów leczenia: całkowitą kermę referencyjną (TRAK), D9o (procent dawki przepisanej przypadającą na 90\% objętości tarczowej PTV), objętości otrzymujące dawkę referencyjną (V100) oraz 150\% (V150) i 200\% (V200) dawki. Oceniono również dawki w najbardziej narażonych $0.1 \mathrm{~cm} 3$ (Do.1cc) oraz 2cm3 (D2cc) pęcherza oraz odbytnicy.

WYNIKI: Założono od 1 do 5 igieł jako uzupełnienie aplikacji dojamowej. Aplikacje dojamowo-śródtkankowe TRN zwiększyły dopromienienie PTV w stosunku do grupy TR - średnio D9o wyniosło odpowiednio 90.4\% i 83.4\% dawki przepisanej. Jednocześnie pozwoliły zmniejszyć narażenie narządów krytycznych - średnie dawki w pęcherzu wyniosły 6.1Gy oraz 6.5Gy dla PDo.1cc, 4.8Gy oraz 5.oGy dla PD2cc,a średnie dawki w odbytnicy 6.1Gy oraz 6.4Gy dla RDo.1cc, 4.8Gy oraz 5.0Gy dla RD2cc odpowiednio dla planów TRN oraz TR. W planach TRN uzyskano również średnio niższy TRAK niż w planach TR (odpowiednio 0.449cGy/m i $0.474 \mathrm{cGy} / \mathrm{m}$ ), mimo zwiększenia odległości punktów specyfikacji dawki A' ze średnio $21 \mathrm{~mm}$ na $23.5 \mathrm{~mm}$ od osi sondy. Nie odnotowano również różnic pomiędzy objętościami V150 oraz V200 w obu grupach. Większą różnicę parametru D90 pomiędzy planami TRN i TR uzyskano dla aplikacji wiedeńskich - 8.8\% (D90 odpowiednio 80.1\% i 71.3\%) niż dla aplikacji „z wolnej ręki” - 5.8\% (D9o odpowiednio 96.9\% i 91.1\%).

WNIOSKI: Aplikacje dojamowo-śródtkankowe pozwalają uzyskiwać lepsze dopromienienie objętości tarczowej niż w przypadku klasycznych aplikacji dojamowych przy jednoczesnym ograniczeniu dawek 
w narządach krytycznych i bez zwiększania objętości wysokich dawek. Większą poprawę objęcia PTV izodozą referencyjną zauważono przy założeniach wiedeńskich niż przy implantowaniu dodatkowych igieł „z wolnej ręki”.

WU-BT-016: Zastosowanie termowizji w ocenie efektów brachyterapii raka podstawnokomórkowego

Agnieszka Cholewka ${ }^{1}$, Łukasz Kapek ${ }^{2}$, Marta Szlag ${ }^{1}$, Piotr Wojcieszek ${ }^{3}$, Sylwia Kellas-Slęczka ${ }^{3}$, Agata Stanek $^{4}$, Karolina Sieroń-Stołtny ${ }^{5}$, Krzysztof Ślosarek ${ }^{1}$, Brygida Białas ${ }^{1}$, Armand Cholewka ${ }^{2}$

(1) Department of Radiotherapy and Brachytherapy Planning, Maria Skłodowska-Curie Memorial Cancer Center and Institute of Oncology, Gliwice, Poland

(2) A. Chelkowski Institute of Physics, Department of Medical Physics, University of Silesia, Katowice, Poland

(3) Brachytherapy Department, Maria Skłodowska-Curie Memorial Cancer Center and Institute of Oncology, Gliwice, Poland

(4) Clinic of Internal Diseases and Physical Medicine School of Medicine with the Division of Dentistry in Zabrze, Bytom, Poland

(5) Department of Physiotherapy, Institute of Physical Medicine, School of Health Sciences Medical University of Silesia, Poland

WPROWADZENIE: Celem pracy była próba oceny przydatności obrazowania termicznego w ocenie efektów brachyterapii u pacjentów z rakiem podstawnokomórkowym (BCC - basal cell carcinoma).

MATERIAŁ I METODA: Badania przeprowadzono na grupie 17 pacjentów ze stwierdzonym histopatologicznie rakiem podstawnokomórkowym. Obrazowanie termiczne wykonywano kamerą Flir Systems E6oprzed rozpoczęciem brachyterapii HDR oraz miesiąc po zakończeniu leczenia.

Do obszarów zainteresowania zaliczono zmianę nowotworową, której granice określone były na podstawie badania przeprowadzonego przez lekarza oraz margines tkanek wokół zmiany. Ponadto w analizach porównawczych ujęto obszar zdrowy umieszczony symetrycznie w stosunku do obszaru zmienionego na policzkach lub czole, w zależności od umiejscowienia zmiany chorobowej u badanego pacjenta.

WYNIKI: Analiza statystyczna otrzymanych parametrów temperaturowych (średnia oraz różnice temperatury średniej między poszczególnymi obszarami zainteresowania) pokazała znamienny statystycznie wzrost wartości poszczególnych parametrów charakteryzujących obszar zmiany po leczeniu w porównaniu do tego samego obszaru przed leczeniem, co może wskazywać na zwiększony metabolizm w tym obszarze, co z kolei może wskazywać na przyśpieszone procesy odbudowy macierzy komórkowej występujące po leczeniu. Podobne zależności otrzymano porównując obszar zmiany chorobowej z obszarem referencyjnym i otoczeniem zmiany.

WNIOSKI: Na podstawie otrzymanych wyników można wyciągnąć wnioski, iż termografia może nieść dodatkowe informacje diagnostyczne oraz dotyczące efektów terapeutycznych w brachyterapii zmian nowotworowych tkanek powierzchniowych. Jednakże wymagane jest potwierdzenie otrzymanych wyników na większej grupie pacjentów.

\section{Wykłady edukacyjne: Teleradioterapia [WE-TT]}

\section{WE-TT-017: Radioterapia protonowa}

\section{Paweł Olko'}

(1) Instytut Fizyki Jądrowej PAN, Kraków, Polska

\section{[Brak streszczenia]}

\section{Wystąpienia ustne: Teleradioterapia [WU-TT]}

WU-TT-018 [Praca nagrodzona]: Metoda błędów izolowanych jako narzędzie do wyboru progów 


\section{tolerancji w analizie gamma}

Marta Giżyńska ${ }^{1,2}$, Monika Bukat ${ }^{2}$, Justyna Cybowska², Mateusz Filipek ${ }^{2}$, Magdalena Garbacz ${ }^{2}$, Ilona Ściśniak², Adam Spyra², Dariusz Szałkowski ${ }^{3}$, Agnieszka Walewska ${ }^{1}$

(1) Centrum Onkologii-Instytut im. Marii Skłodowskiej-Curie w Warszawie, Polska

(2) Uniwersytet Warszawski, Wydział Fizyki, Zakład Fizyki Biomedycznej, Warszawa, Polska

(3) Politechnika Warszawska, Wydziat Fizyki, Warszawa, Polska

WPROWADZENIE: Analiza parametru gamma jest często stosowaną metodą oceny wyniku weryfikacji dozymetrycznej dla technik wysokospecjalistycznych w radioterapii. Nie pozwala ona jednak na jasne określenie źródeł błędów. W konsekwencji trudne jest ustalenie progu tolerancji analizy gamma, dla którego wykryte błędy mają znaczenie kliniczne. Opracowana przez nasz zespół metoda błędów izolowanych pozwala na porównanie metodą analizy gamma symulowanego pomiaru z planem idealnym. Symulowany pomiar jest obarczony jedynie znanym, konkretnym i wyizolowanym błędem. Proponowana metoda może służyć do ustalenia progów tolerancji analizy gamma, bez konieczności wykonywania pomiarów a w konsekwencji bez wprowadzania czynnika związanego z błędem pomiarowym.

MATERIAŁ I METODA: Źródła numerycznie wygenerowanych błędów zostały podzielone na: zależne od fantomu (np. zależność odpowiedzi detektorów od mocy dawki - DR , błąd pozycjonowania fantomu pomiarowego) i zależne od akceleratora (np. błąd ustawienia głowicy, błąd pozycjonowania MLC). W systemie planowania leczenia przygotowano plany weryfikacyjne dla pojedynczych pól otwartych i planów klinicznych (lokalizacje: głowa i szyja, mózg). Następnie plany te były modyfikowane przez wprowadzenie błędu realizacji lub pomiaru. Otrzymany w ten sposób rozkład dawki przekształcano na plik pomiarowy. Rozdzielczość punktów w wygenerowanym pliku pomiarowym była równa faktycznej rozdzielczości metody weryfikacji. Testy wykonano dla fantomu ArcCheck (SunNuclear).

WYNIKI: Błąd rotacji i nachylenia fantomu nie wpływa na wynik analizy gamma $2 m m$ 2\%. Rotacja fantomu $0 \pm 1^{\circ}$ daje różne wyniki w zależności od kierunku rotacji Zależność odpowiedzi detektorów od DR przy analizie $2 \mathrm{~mm} 2 \%$ dawki lokalnej skutkowała dla $3 \%$ planów o średnim DR $\leq 300$ planów niespełnieniem kryterium gamma 95\%. Błąd odległości listków ma większe znaczenie dla planów w lokalizacji głowa i szyja , gdzie $1 \mathrm{~mm}$ błąd wpływa znacząco na wynik analizy gamma 3mm 3\% dawki lokalnej. W planach o mniejszej modulacji podobnie jak dla błędu związanego z systematycznym przesunięciem MLC detekcja błędu jest trudniejsza i wymaga użycia ostrzejszych kryteriów takich jak gamma dla dawki lokalnej lub gamma $2 \mathrm{~mm}$ $2 \%$.

WNIOSKI: Dla fantomu ArcCheck największy wpływ na wyniki analizy gamma, spośród testowanych błędów, ma błąd w odległości pomiędzy naprzeciwległymi listkami. Wykrycie 1mm błędu pozycjonowania MLC dla planów w lokalizacji głowa i szyja, przy tolerancji 95\%, wymaga kryterium gamm 3\%/3mm dawki lokalnej lub ostrzejszych. Wpływ błędów wynikających z zależności od DR dla planów VMAT powinny zostać poddane dalszej analizie. Błędy pozycjonowania fantomu ArcCheck, mieszczące się w zakresie podanym w specyfikacji) nie mają wpływu na wyniki analizy gamma 3mm/3\% i 2mm/2\%.

\section{WU-TT-019: Krajowy audyt poprawności wyznaczania rozkładów dawki w radioterapii IMRT Krzysztof Chełmiński ${ }^{1}$, Wojciech Bulski ${ }^{1}$, Wioletta Ślusarczyk-Kacprzyk ${ }^{1}$, Piotr Ulkowski ${ }^{1}$}

(1) Zakład Fizyki Medycznej, Centrum Onkologii, Warszawa, Polska

WPROWADZENIE: We współczesnej radioterapii rutynowo stosowane są kolimatory wielolistkowe w celu modulacji intensywności wiązki promieniowania. Weryfikacja dozymetryczna planów IMRT w większości przypadków polega na pomiarach rozkładów dawki od pojedynczych pól. Niniejsza praca przedstawia jest metodę audytu dozymetrycznego typu „end-to-end”, obejmującego wynik procesu przygotowania i aplikacji radioterapii - od obrazowania przez planowanie leczenia po napromienianie.

MATERIAŁ I METODA: Użyta metodologia została opracowana w ramach projektu IAEA „Coordinated Research Project E2.40.18”. W trakcie realizacji projektu opracowano i skonstruowano dedykowany fantom z polistyrenu, zawierający wkładki wykonane z materiału Solid Water High Equivalency (HE) o gęstości elektronowej wody reprezentujące objętości PTV oraz OAR. Konstrukcja fantomu pozwala 
na umieszczenie we wkładkach PTV i OAR filmów radiochromowych oraz detektorów TL. Uczestnicy audytu byli zobowiązani do wykonania badania CT fantomu, do przygotowania na jego podstawie planu leczenia zgodnego z wymaganiami dotyczącymi dawek w PTV i w OAR, oraz do napromienienia fantomu z umieszczonymi wewnątrz detektorami, zgodnie z tym planem. Rozkłady dawek zarejestrowane przy pomocy filmów porównano z rozkładami zaplanowanymi stosując metodę indeksu Gamma. Dawki obliczone przez systemy planowania dla objętości odpowiadających rozmiarom TLD porównano z dawkami odczytanymi z napromienionych próbek TLD.

WYNIKI: Audyt jest w fazie pilotażowej. Wzięło w nim udział 13 ośrodków w tym 12 wyposażonych w akceleratory z MLC. Już na tym etapie można ocenić, że opracowana metodyka sprawdza się w praktyce i pozwala ocenić procedury radioterapii w poszczególnych ośrodkach choć konieczne były pewne jej modyfikacje. Docelowo, w 2017 roku, audytowi poddana zostanie większość ośrodków w Polsce. „Percentage passing rate" indeksu gamma (3 $\mathrm{mm} / 3 \%$ dawki w izocentrum) w porównaniu filmów z planami uzyskano wyższy niż 95\% w 11 ośrodkach. Dawki odczytane dla TLD umieszczonych w PTV i OAR różniły się od zaplanowanych o nie więcej niż 5\% odpowiednio w 10 i 9 ośrodkach. Uzyskane różnice dawek przekraczające 5\% wymagają wyjaśnienia i ewentualnie powtórzenia pomiarów.

WNIOSKI: Audyt był projektowany jako wysyłkowy, ale praktyczne względy sprawiły, że był realizowany na drodze wizyt w ośrodkach i nadzorowaniu prawidłowego przeprowadzenia procedury przez uczestników. Znaczny wpływ na wyniki uzyskiwane przy pomocy detektorów TL ma precyzja pozycjonowania fantomu na stole akceleratora. Wyniki uzyskane przy pomocy detektorów TL są skorelowane z wynikami uzyskanymi przy pomocy filmów radiochromowych.

WU-TT-020: Wpływ wielkości szczęki, współczynnika modulacji i skoku na jakość planów tomoterapeutycznych z eskalacją dawki w oparciu o obrazy FDG PET u chorych leczonych na nowotwór w rejonie głowy i szyi

Małgorzata Skórska ${ }^{1}$, Tomasz Piotrowski ${ }^{1,2}$, Adam Ryczkowski ${ }^{1}$, Joanna Kaźmierska ${ }^{2,3}$

(1) Zakład Fizyki Medycznej, Wielkopolskie Centrum Onkologii, Poznań, Polska

(2) Katedra i Zakład Elektroradiologii, Uniwersytet Medyczny w Poznaniu, Poznań, Polska

(3) II Zakład Radioterapii, Wielkopolskie Centrum Onkologii, Poznań, Polska

WPROWADZENIE: Tomoterapia spiralna jest jednym $\mathrm{z}$ najbardziej wyrafinowanych urządzeń pozwalających dostarczyć bardzo konformalny i jednorodny rozkład dawki w obszarze tarczowym przy jednoczesnym zaoszczędzeniu narządów krytycznych. Celem pracy jest zweryfikowanie które parametry planu (wielkość szczęki (FW), współczynnik skoku (PF), współczynnik modulacji (MF)) mają największy wpływ na rozkład dawki oraz czas leczenia pacjenta na aparacie tomoterapeutycznym z uwzględnieniem eskalacji dawki w oparciu o obrazy FDG PET

MATERIAŁ I METODA: Dla 12 pacjentów ze zdiagnozowanym nowotworem w rejonie głowy i szyi, którzy zostali poddani obrazowaniu 18F-FDG-PET/CT, wykonano łącznie 96 tomoterapeutycznych planów leczenia. Na podstawie wysycenia poszczególnych wokseli na obrazach PET dokonano eskalacji dawki terapeutycznej do wartości 96Gy w 32 frakcjach, przy użyciu 7 dyskretnych poziomów eskalowanej dawki. Następnie dla każdego pacjenta przygotowano tomoterapeutyczne plany leczenia różniące się wielkością FW, MF i PF. Plany zostały porównane względem siebie pod kątem rozkładu dawki w obszarze tarczowym korzystając z histogramu jakość-objętość (QVH) i współczynnika jakości (QF). Ponadto porównano dawki w narządach krytycznych, obszarze tarczowym oraz przeanalizowano czas napromieniania.

WYNIKI: Najlepszy współczynnik jakości osiągnięto dla planów gdzie wielkość szczęki wynosiła $1.05 \mathrm{~cm}$ $(\mathrm{QF}=2.10)$, natomiast najgorszy dla szczęki 5.0cm $(\mathrm{QF}=3.04)$. Zastosowanie $\mathrm{FW}=1.05 \mathrm{~cm}$ oraz $\mathrm{MF}=5 \mathrm{prowadzi}$ do osiągnięcia najdłuższego czasu leczenia pacjenta - powyżej 25min, natomiast najkrótszy czas osiągnięto przy zastosowaniu $\mathrm{FW}=2.5 \mathrm{~cm}$ oraz $\mathrm{MF}=3$-poniżej 8min. Analiza histogramów dawka-objętość wykazała, że największy wpływ na jakość uzyskanego rozkładu dawki miał wybór FW, natomiast wpływ MF oraz PF był znacznie mniej istotny.

WNIOSKI: Tomoterapia spiralna jest odpowiednim narzędziem w celu realizacji planów leczenia przygotowanych w technice “dose painting”. Zmiany FW oraz MF miały największy wpływ na jakość rozkładu 
dawki i czas leczenia pacjenta. Zmiany w PF miały wpływ jedynie na dawkę w narządach krytycznych.

\section{WU-TT-021: Przygotowanie do planowania radioterapii pacjentów z protezami kości} Ryszard Dąbrowski ${ }^{1}$, Marzena Morawska-Kaczyńska ${ }^{1}$

(1) Zakład Fizyki Medycznej, Centrum Onkologii, Warszawa, Polska

WPROWADZENIE: Planowanie radioterapii pacjentów z protezami kości wykonanymi z materiału o wysokiej liczbie atomowej wymaga wprowadzenia specjalnych metod postępowania. Celem pracy jest opracowanie metod przygotowania danych CT pacjentów z protezami kości do planowania radioterapii i weryfikacja dozymetryczna obliczeń systemu planowania Monaco z algorytmem Monte Carlo w obecności tytanu, mosiądzu i stali.

MATERIAŁ I METODA: Zaproponowane metody postępowania zastosowano do protezy kości kończyny dolnej ze stawem kolanowym, wykonanej z tytanu i stali. Na podstawie analizy rozkładów dawek na zdjęciu portalowym protezy wykonanym w wiązce terapeutycznej fotonów X 6 MV określono skład protezy w różnych przekrojach. Wykonano badanie CT protezy zanurzonej w wodzie z zastosowaniem rozszerzonego trybu zapisu danych i korekcją artefaktów MAR. Dla tego samego układu wykonano pomiary rozkładów dawki w płaszczyźnie poniżej protezy dla wiązki fotonów $6 \mathrm{MV}$, do tego celu użyto filmów Gafchromic EBT3. Wykonano również obliczenia rozkładów dawki z użyciem systemu Monaco dla dwóch scenariuszy: dla nadpisanej manualnie w systemie Monaco gęstości elektronowej stali i tytanu oraz dla zmodyfikowanych osobno dla tytanu i stali krzywych konwersji liczb Hausfielda na gęstości elektronowe (HU-ED).

WYNIKI: W obydwu przypadkach uzyskano zgodność dawek pomiarowych i obliczonych w 3 \% pod częściami protezy wykonanymi wyłącznie z tytanu bądź stali. W obszarach protezy wykonanych z różnych materiałów nie było możliwe takie dobranie krzywych konwersji HU-ED, by zgodność obliczeń i pomiarów mieściła się w 3 \%. Zgodność obliczeń z pomiarami poprawiła się w obszarze stalowym protezy z rdzeniem tytanowym, gdy gęstość elektronowa tytanu w systemie Monaco została nadpisana manualnie.

WNIOSKI: Zaproponowane metody i system Monaco z algorytmem Monte Carlo można zastosować do planowania radioterapii pacjentów z protezami kości. W przypadku protez z elementami stalowymi o mieszanej konstrukcji niepewności dozymetryczne obliczeń dawki mogą przekraczać 3 \%.

\section{WU-TT-022: Wdrożenie techniki napromieniania piersi na głębokim wdechu, celem redukcji dawki w sercu, przy użyciu systemu RPM. Marzena Janiszewska', Maciej Raczkowski ${ }^{1}$}

(1) Zakład Fizyki Medycznej, Dolnośląskie Centrum Onkologii we Wroctawiu, Polska

WPROWADZENIE: Praca przedstawia doświadczenia związane z techniką napromieniania pacjentek z lewostronnym rakiem piersi na wstrzymanym oddechu, kontrolowanym za pomocą systemu RPM.

MATERIAŁ I METODA: Analizie poddano 50 chorych z lewostronnym rakiem piersi. U każdej pacjentki wykonano 2 TK na głębokim i swobodnym wdechu kontrolowanym za pomocą RPM. Zastosowano techniki hybrydowe 3D/VMAT oraz IMRT-SIB Przed ekspozycją wykonywano 2 zdjęcia kV o i 90 na głębokim wdechu służące do weryfikacji i korekcji ustawienia izocentrum, oraz 2 zdjęcia MV, pól tangencjalnych. Odtwarzalność ruchów oddechowych badano za pomocą pomiarów pomiędzy mostkiem a kręgosłupem na bocznych polach kV w płaszczyźnie izocentrum, oraz za pomocą odległości CLD w polach MV. Porównano dawkę średnią oraz V2oGy w płucach oraz dawkę średnią, V25Gy, dawkę obejmującą 10cm3 serca oraz średnią dawkę w lewej tętnicy wieńcowej.

WYNIKI: Wyniki przedstawiono w postaci przykładowych rozkładów izodoz dla technik 3D/VMAT oraz IMRT-SIB. Uzyskane wartości dawki minV98\% w PTV pierś oraz D98\%, D50\% oraz D2\% w PTV boost w obu technikach nie różniły się istotnie. Dla różnych technik planowania rozkładu dawki zastosowano system RPM.

Średnia różnica głębokości oddechów mierzona jako odległość pomiędzy mostkiem a kręgosłupem na wysokości izocentrum na każdym ze zdjęć set-up 90 w porównaniu z KT lokalizacyjnym nie wylkazywała 
znaczących róćnic. Różnica w CLD pomiędzy polami tangencjalnymi MV w trakcie ekspozycji wynosiła średnio $0,13 \mathrm{~mm}, \Sigma 0,35, \sigma 0,49$. Napromienianie na wdechu pozwoliło na istotną statystycznie redukcję średniej dawki w sercu o $50,07 \% \pm 21,9 \%$ p0,00001 z 6,21 \pm 3,5 Gy do 2,84 \pm 1,9 Gy oraz redukcję obszaru serca objętego

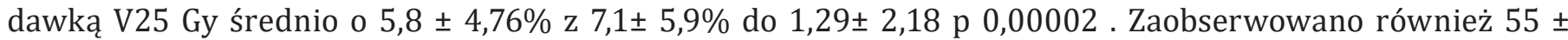
$31 \%$ redukcję dawki obejmującej $10 \mathrm{~cm} 3$ serca z 37,85 17 Gy do $16,75 \pm 16$ Gy p 0,00001 oraz redukcję dawki średniej w CLA średnio o 17,25 11,8 Gy (28,38 Gy v 11,12 Gy) p 0,000002 dla planów na wdechu.

WNIOSKI: Zastosowanie techniki DIBH pozwala na lepszy rozkład dawki w obszarze serca, oraz tętnicy wieńcowej. Zmniejszając tym samm przesłanki do późnych powikłań kardiologicznych.

\section{WU-TT-023: Niskie dawki poza obszarem napromieniania: symulacje Monte Carlo, pomiar i odpowiedź radiobiologiczna in vitro komórek}

Marta Kruszyna ${ }^{1,2}$, Agnieszka Skrobała ${ }^{1,2}$, Wiktoria Suchorska ${ }^{1,2}$, Karolina Zaleska ${ }^{2}$, Adam Konefał ${ }^{3}$, Anna Kowalik², Weronika Jackowiak4 ${ }^{4}$, Małgorzata Skórska², Sebastian Adamczyk², Julian Malicki ${ }^{1,2}$

(1) Katedra i Zakład Elektroradiologii, Uniwersytet Medyczny, Poznań, Polska

(2) Zakład Fizyki Medycznej, Wielkopolskie Centrum Onkologii, Poznań, Polska

(3) Zakład Fizyki Jądrowej i Jej Zastosowań, Uniwersytet Śląski w Katowicach, Polska

(4) Zakład Radioterapii 1, Wielkopolskie Centrum Onkologii, Poznań, Polska

WPROWADZENIE: W zaawansowanych technikach radioterapii jednym z problemów jest poziom dawek poza obszarem napromieniania. Dawki te nie są prawidłowo obliczane przez algorytmy zaimplementowane w komputerowych systemach planowania leczenia. Celem pracy było zbadanie poza obszarem wiązki pierwotnej: a) właściwości promieniowania rozproszonego, b) rozkładu dawki promieniowania jonizującego, c) wpływu dawek promieniowania jonizującego na odpowiedź radiobiologiczną in vitro komórek.

MATERIAE I METODA: Pomiary wykonano w specjalnie przygotowanym fantomie wodnym, z wbudowanymi 7 punktami pomiarowymi (w osi wiązki (P1), 10cm (P2), 15cm ( $\left.\mathrm{P}_{3}\right), 20 \mathrm{~cm}\left(\mathrm{P}_{4}\right), 25 \mathrm{~cm}\left(\mathrm{P}_{5}\right)$, $30 \mathrm{~cm}(\mathrm{P} 6), 35 \mathrm{~cm}\left(\mathrm{P}_{7}\right)$ poza osią) na sześciu głębokościach o,5, 1,6, 4, 6, 8 i 10cm dla pola 10x10cm2 (rycina 1). Zadano dawkę 75Gy w osi wiązki fotonowej dla dwóch energii: 6 i 20MV. W punktach pomiarowych umieszczono detektory, a także butelki z komórkami nowotworowymi piersi MDA-MB-231. Spektrum energetyczne wraz z średnią energią wyznaczono dla powyższych warunków dla energii $6 \mathrm{MV}$ za pomocą symulacji Monte Carlo w kodzie Geant4. Pomiary dawek zostały wykonane przy użyciu detektorów termoluminescencyjnych (TLD): TLD100, TLD700, TLD600 (Harshaw) i filmów dozymetrycznych Gafchromic EBT (ISP). Komórki nowotworowe piersi umieszczone w 7 punkatch pomiarowych i zostały napromienione czterema dawkami: 1,5, 2,0, 2,5 i 3,oGy i wyznaczono krzywe przeżyciowe na podstawie oceny pęknięć podwójnoniciowych DNA. Wykonano także test klonogenny i cytometrię przepływową.

WYNIKI: Dla podanej dawki 75Gy w osi wiązki dawka zmierzona w stosunku do dawki w osi wiązki wynosiła w wybranych punktach odpowiednio w P2: 2-2,5Gy dla 6MV, 1,5-2,oGy dla 20MV oraz kilka cGy dla punktu P7. Dla punktu P4 dawka zmierzona dla promieniowania neutronowego wynosiła 3,5mSv/Gy dla energii 2oMV. Za pomocą symulacji komputerowych Monte Carlo wykazano, że średnia energia obniża się znacznie poza granicą pola napromieniania w stosunku do osi wiązki dla energii $6 \mathrm{MV}$ : w odległości $10 \mathrm{~cm}$ średnia energii jest na poziomie $0,3 \mathrm{MeV}$ w porównaniu do $1,5 \mathrm{MeV}$ w osi; a także wraz ze wzrostem odległości od granicy pola średnia energia stopniowo wzrasta: na głębokości $1,6 \mathrm{~cm}$ i $15 \mathrm{~cm}$ poza osią, średnia energia wynosiła 0,205 w porównaniu do 0,252 na $20 \mathrm{~cm}$ poza osią. Zaobserwowano niewielki spadek o 3-5\% w krzywej przeżycia w komórkach napromieniowanych poza osią wiązki.

WNIOSKI: Wykazane, że poziomy dawek szczególnie dla energii 20MVnależy wziąć pod uwagę przy określaniu ochrony radiologicznej pacjentów. Promieniowanie rozproszone wywołuje biologiczną reakcję w warunkach in vitro na komórki poza polem. 


\title{
Wykłady edukacyjne: Diagnostyka obrazowa [WE-DO]
}

\author{
WE-DO-024: Obrazowanie medyczne \\ Ryszard Kowski ${ }^{1,2}$ \\ (1) Centrum Medyczne Ksztatcenia Podyplomowego, Warszawa, Polska \\ (2) Łódzki Ośrodek Szkoleniowy, Łódź, Lolska
}

\section{[Brak streszczenia]}

WE-DO-025: Pozytonowa tomografia emisyjna

Pawel Moskal ${ }^{1}$

(1) Zakład Medycyny Nuklearnej, Wydział Fizyki, Astronomii i Informatyki Stosowanej, Uniwersytet Jagielloński, Kraków, Polska

\section{[Brak streszczenia]}

WE-DO-026: Rezonans magnetyczny

Zofia Drzazga ${ }^{1,2}$

(1) Instytut Fizyki im. A. Chełkowskiego, Zakład Fizyki Medycznej, Uniwersytet Ślaski, Katowice, Polska

(2) Śląskie Międzyuczelniane Centrum Edukacji i Badan Interdyscyplinarnych, Chorzów, Polska

\section{[Brak streszczenia]}

\section{Wystąpienia ustne: Diagnostyka Obrazowa [WU-DO]}

WU-DO-027 [Praca nagrodzona]: Zastosowanie głębokich konwolucyjnych sieci neuronowych do klasyfikacji obrazów medycznych: fotografii czerniaka skóry i radiografii planarnej klatki piersiowej.

Krzysztof Koras ${ }^{1}$, Józef Ginter ${ }^{1}$

(1) Uniwersytet Warszawski, Wydziat Fizyki, Warszawa, Polska

WPROWADZENIE: Celem pracy było sprawdzenie przydatności stosowania parametryzacji obrazu opartej na głębokich konwolucyjnych sieciach neuronowych (CNN), wytrenowanych na obrazach niemedycznych, do zastosowań w automatycznej klasyfikacji obrazów medycznych (metoda zwana fine tuning).

MATERIAŁ I METODA: Wykorzystano do tego pobrane z ogólnodostępnych w internecie baz danych 900 fotografii czerniaka skóry zaklasyfikowanych jako złośliwe lub łagodne oraz 246 radiografii planarnych płuc w trzech klasach - zdrowy, zmiana łagodna i zmiana złośliwa. W pierwszym wypadku dokonywana była klasyfikacja binarna, w drugim zaś oprócz binarnej (odróżniającej obrazy z guzem od zdrowych), oceniana została zdolność algorytmu do dokonania klasyfikacji trzyklasowej.

Porównano pięć różnych głębokich sieci neuronowych, które odniosły sukcesy w ramach konkursu ImageNet Large Scale Visual Recognition Challenge (ILSVRC) w latach 2012-2015, uczonych na ogólnodostępnym zbiorze ponad miliona obrazów ImageNet. Dla każdego modelu sieci osobno sprawdzono działanie jako deskryptora każdą z trzech ostatnich warstw. Obrazy medyczne podawano jako wejście CNN, z której wektory wyjściowe odpowiednio przeskalowane służyły z kolei jako wejście do jednego z dwóch algorytmów klasyfikujących: SVM oraz drzewo decyzyjne, które były uczone rozpoznawania obrazów. Wektory wyjściowe z CNN miały od 1000 do 4096 wymiarów.

WYNIKI: Jako miarę skuteczności działania algorytmu przyjęto trafność, czułość i precyzję oraz współczynnik F1 (średnią harmoniczną dwóch ostatnich), które porównywano z odpowiednimi wartościami tych parametrów dla klasyfikatorów zerowego (lub jedynkowego) i losowego. Dla pierwszego zbioru danych 
uzyskano maksymalną trafność 83\%, niewiele przekraczającą wartość 81\% dla klasyfikatora zerowego $(\mathrm{F} 1=0)$, przy oczywiście dużo wyższej precyzji i czułości $(\mathrm{F} 1=0.54)$. Dla drugiego zbioru danych uzyskano maksymalną trafność 75\% i F1=0.79 dla klasyfikacji binarnej (przy trafności dla klasyfikatora jedynkowego 62\%, F1=0.76) oraz trafność 60\% i F1=0.58 (przy trafności dla klasyfikatora dwójkowego 37\% i F1=0.18).

WNIOSKI: Klasyfikacja SVM dawała lepsze rezultaty niż drzewa decyzyjne, a parametryzacja przedostatnią lub trzecią od końca warstwą okazała się być skuteczniejsza niż warstwą ostatnią. Pomiędzy skutecznością zastosowania różnych modeli CNN różnice były niewielkie. Udało się wytworzyć algorytmy przydatne do konstrukcji systemu wsparcia diagnozy lekarskiej (CAD) w oparciu o dość nieliczne zbiory obrazów uczących. Wyniki osiągnięte w tej pracy są nieco gorsze od najlepszych wyników automatycznej klasyfikacji raportowanych dla tych samych danych.

WU-DO-O28: Dawki promieniowania X w mammograficznych badaniach skryningowych w Polsce a stosowane rejestratory obrazu

Ewa Fabiszewska ${ }^{1}$, Katarzyna Pasicz ${ }^{1}$, Iwona Grabska ${ }^{1}$

(1) Zakład Fizyki Medycznej, Centrum Onkologii, Warszawa, Polska

WPROWADZENIE: Od 2007 roku znacznie zmieniły się rodzaje rejestratora obrazu w placówkach mammograficznych realizujących program badań przesiewowych w Polsce. Systemy z detektorem filmowym (SF) są zastępowane przez systemy CR i DR. Celem niniejszej pracy była ocena zmian, jakim podlegają wartości średnich dawek gruczołowych dla ekspozycji 4,5 cm PMMA (MGD4,5cmPMMA) w związku ze zmianą rodzaju rejestratora obrazu.

MATERIAŁ I METODA: Materiał niniejszej pracy stanowiło 1499 protokołów z kontroli przeprowadzonych przez fizyków z 16 Wojewódzkich Ośrodków Koordynujących w latach 2007, 2011, 2012 i 2013. Dane dotyczące liczby aparatów mammograficznych w roku 2014 zaczerpnięto z raportu Centralnego Ośrodka Koordynującego. Dla każdego roku wyznaczono wartość średnią, odchylenie standardowe oraz wartości minimalne i maksymalne MGD4,5cmPMMA łącznie dla wszystkich systemów mammograficznych, a następnie dla każdego systemu SF, CR i DR oddzielnie. Porównano te wartości w kolejnych latach.

WYNIKI: Liczba aparatów w roku 2007 wynosiła 298. Natomiast w latach 2011-2014 liczba aparatów oscylowała wokół liczby 400. Utrzymanie trendu wzrostu liczby systemów CR i DR w stosunku do liczby systemów SF skutkowałoby tym, że w połowie 2022 roku w skryningu w Polsce nie byłoby żadnego systemu SF. Przy czym stosunek liczbowy systemów CR do DR wyniósłby 2,5.

W latach 2011-2014 wartości średnie MGD4,5cmPMMA: dla systemów CR były wyższe niż dla systemów SF: o 25\%, o 26\% i o 28\%; dla systemów DR były wyższe niż dla systemów SF: o 15\%, o 4\% i o 5\%; dla systemów CR były wyższe niż dla systemów DR o 13\%, o 23\% i o 24\%. Jednak we wszystkich przypadkach, wartości średnie MGD4,5cmPMMA były w akceptowalnym poziomie 2,5 mGy.

Zakładając, że do roku 2022 tempo wzrostu liczby aparatów CR i DR będzie takie samo jak w latach 20112014, a różnice w wartości dawek dla poszczególnych systemów nie uległyby zmianie, to oszacowana wartość średnia MGD4,5cmPMMA w roku 2022 byłaby większa o około 12\% od wartości średniej MGD4,5cmPMMA otrzymanej dla wszystkich typów systemów mammograficznych w 2013 roku.

WNIOSKI: Średnie wartości MGD wyznaczone dla ekspozycji fantomu o grubości 4,5 cm dla systemów CR są znacząco wyższe niż dla systemów SF oraz dla systemów DR. Koniecznym wydaje się podjęcie działań w kierunku obniżenia dawek promieniowania X przede wszystkim w przypadku systemów CR.

WU-DO-029: Analiza fraktalna obrazów rezonansu magnetycznego pacjentów z podejrzeniem nowotworu prostaty

Maciej Zdrojkowski ${ }^{1}$, Edward Oczeretko², Dorota Jurgilewicz ${ }^{3}$, Marcin Hładuński ${ }^{3}$

(1) Zakład Fonoaudiologii Klinicznej i Logopedii, Uniwersytet Medyczny w Białymstoku, Polska

(2) Zakład Biocybernetyki i Inżynierii Biomedycznej, Politechnika Białostocka, Polska

(3) Samodzielna Pracownia Laboratorium Obrazowania Molekularnego, Uniwersytet Medyczny w Białymstoku, Polska 
WPROWADZENIE: Celem pracy było przeprowadzenie analizy fraktalnej obrazów rezonansu magnetycznego pacjentów z podejrzeniem nowotworu prostaty. Parametrem do analizy były wartości wymiaru fraktalnego WFD szacowanego przy pomocy dwóch różnych algorytmów.

MATERIAŁ I METODA: Do badań wykorzystano skany przedstawiające gruczoł krokowy pacjentów diagnozowanych z powodu raka gruczołu krokowego w pracowni rezonansu magnetycznego Laboratorium Obrazowania Molekularnego Białostockiego Parku Naukowo-Technologicznego. Opracowaniu poddano obrazy T2-zależne badań rezonansu magnetycznego (MR) wykonanych za pomocą 3-teslowego aparatu Biograph mMR (Siemens, Niemcy). Analizę fraktalną przeprowadzono wykorzystując skany 10 pacjentów z rakiem prostaty i 3 zdrowych osób. Zastosowano dwa sposoby obliczeń: metodę wykorzystującą wariogram (WM) oraz metodę Fouriera (FT) w wybranych regionach zainteresowania 64x64.

WYNIKI: W przypadku podejścia fourierowskiego, oszacowany wymiar fraktalny wynosił 2,656 $\pm 0,081$ dla obrazów z podejrzeniem nowotworu prostaty, natomiast 2,494 \pm 0,093 dla prostaty zdrowej. W metodzie z wariogramem otrzymano następujące wyniki: 2,887 $\pm 0,083 \mathrm{w}$ przypadku podejrzenia nowotworu i 2,68 $\pm 0,118 \mathrm{w}$ przypadku pacjenta zdrowego.

WNIOSKI: W obu metodach obliczeniowych wymiar fraktalny regionów przedstawiających gruczoł krokowy z podejrzeniem nowotworu charakteryzuje się nieznacznie wyższymi wartościami niż analogicznych regionów prostaty osób zdrowych. Różnice wartości WFD wyliczonych metodą WM są podobne do uzyskanych metodą FT, co wskazuje na równorzędność obu metod pomiaru. W celu dokładnej oceny przydatności klinicznej pomiarów WFD jako jednego z parametrów diagnostycznych analizy obrazów MR w raku prostaty planowane jest powiększenie liczebności badanych grup.

\section{WU-DO-030: Ocena parametrów obrazowania aparatury ultrasonograficznej}

Ewa Fabiszewska ${ }^{1}$, Katarzyna Pasicz ${ }^{1}$, Witold Skrzyński ${ }^{1}$, Wioletta Ślusarczyk-Kacprzyk ${ }^{1}$, Iwona Grabska ${ }^{1}$ (1) Zakład Fizyki Medycznej, Centrum Onkologii - Instytut im. Marii Skłodowskiej-Curie w Warszawie, Polska

WPROWADZENIE: Uszkodzenie lub zużycie aparatury ultrasonograficznej może wiązać się z pogorszeniem jakości obrazowania. Pomimo to w Polsce nie istnieje prawny obowiązek poddawania aparatury ultrasonograficznej kontroli jakości. Autorzy postanowili ocenić jakość obrazowania dla aparatury ultrasonograficznej stosowanej w Centrum Onkologii - Instytucie im. Marii Skłodowskiej-Curie w Warszawie (COI).

MATERIAŁI METODA: Ocenęparametrówjakościobrazu przeprowadzonodla 22aparatówwyposażonych w 46 sond (22 sondy liniowe, 19 konweksowych, 5 sektorowych). Testy wykonano przy użyciu fantomu Multi-Purpose, Multi-Tissue Utrasound Phantom model o4oGSE firmy CIRS. Dla każdego aparatu i każdej sondy wzrokowo oceniano maksymalną głębokość obrazowania, głębokość martwej strefy, dokładność pomiaru odległości, rozdzielczość przestrzenną, jednorodność obrazu, widoczność obiektów bezechowych, widoczność obiektów do oceny skali szarości. Metody i kryteria oceny były oparte na publikacjach AAPM, IPEM i firmy Gammex.

WYNIKI: Największe głębokości obrazowania otrzymano dla sond konweksowych (do $17 \mathrm{~cm}$ ) i sektorowych (do $16 \mathrm{~cm}$ ). Dla jednej z sond konweksowych zmierzona głębokość obrazowania wyniosła tylko 5,5 cm, co stanowi wartość porównywalną z typowymi wynikami dla sond liniowych. Mierzone odległości różniły się od wartości rzeczywistych do $2 \mathrm{~mm}$ w kierunku podłużnym i do 2,6 $\mathrm{mm}$ w kierunku poprzecznym. Dla 89\% skontrolowanych sond głębokość martwej strefy wyniosła o mm, najgorszy wynik (3 mm) odnotowano dla najstarszej sondy, używanej od 1995 roku. Rozdzielczość przestrzenna nie przekraczała 5,o mm i była najlepsza dla sond liniowych (do $1 \mathrm{~mm}$ w kierunku równoległym, do $3 \mathrm{~mm} \mathrm{w}$ kierunku poprzecznym). Dla czterech sond stwierdzono artefakty w postaci dużego zaszumienia obrazu, dla czterech sond w postaci linii na obrazie. Dla 29\% sond stwierdzono obecność zniekształceń obiektów bezechowych. Dla $89 \%$ sond widoczne było więcej niż 4 obiekty do oceny skali szarości, dla jednej sondy liniowej widoczne były tylko dwa obiekty.

WNIOSKI: Stwierdzono różnice w jakości obrazowania między poszczególnymi aparatami i sondami, także pomiędzy sondami o zbliżonej konstrukcji i zastosowaniu. Uzyskane wyniki będą stanowić wartości odniesienia do oceny wyników testów wykonanych w przyszłości oraz mogą posłużyć użytkownikom do oceny przydatności poszczególnych aparatów i sond do wykonywania określonych rodzajów badań. 


\title{
SESJE PLAKATOWE
}

\section{Sesja plakatowa: Nanotechnologia [SP-NT]}

\author{
SP-NT-031: Nanocząstki magnetyczne jako materiał dźwiękoaktywny w hipertermii \\ ultradźwiękowej \\ Arkadiusz Józefczak, Katarzyna Kaczmarek \\ (1) Instytut Akustyki, Wydziat Fizyki, Uniwersytet im. Adama Mickiewicza w Poznaniu, Polska
}

WPROWADZENIE: Celem badań było zastosowanie nanocząstek magnetycznych do poprawy skuteczności hipertermii ultradźwiękowej. Fale ultradźwiękowe oddziałują czynnie na tkankę biologiczną co wywołuje liczne nieodwracalne lub utrzymujące się stosunkowo długo efekty. Silnej absorpcji energii akustycznej towarzyszy wydzielanie się ciepła i lokalne nagrzewanie tkanek. Można znacznie podwyższyć skuteczność tej metody poprzez zastosowanie tak zwanych substancji dźwiękoaktywnych zwiększających współczynnik pochłaniania fali ultradźwiękowej w tkance i co za tym idzie, ilość wydzielanego ciepła. Jednym z kandydatów na taką substancję są nanocząstki o rozmiarach z zakresu 10-300 $\mathrm{nm}$.

MATERIAŁIMETODY:Wbadaniach wykorzystanofantomyagaroweimitującetkanki.Zostaływyznaczone właściwości akustyczne (prędkość propagacji oraz współczynnik pochłaniania fali ultradźwiękowej) fantomów agarowych oraz fantomów agarowych z nanocząstkami magnetytowymi o rozmiarach $10 n m$. Następnie próbki zostały poddane badaniom hipertermii ultradźwiękowej - rejestrowano wzrost temperatury pod wpływem działania fali akustycznej.

WYNIKI: Uzyskane wyniki eksperymentalne pokazały, że obecność nanocząstek magnetycznych w fantomach agarowych wyraźnie wpływa na ich właściwości akustyczne - zwiększa współczynnik pochłaniania. Spowodowało to, że rejestrowany wzrost temperatury wywołany hipertermią ultradźwiękową, dla próbek agarowych z nanocząstkami magnetycznymi, był wyraźnie większy niż ten uzyskany dla próbek bez nanocząsteczek. Wszystkie uzyskane wyniki przeprowadzonych badań potwierdziły fakt, iż dodanie nanocząstek magnetytowych do fantomów zwiększa efekt termiczny hipertermii.

WNIOSKI: Nanocząstki mogą być wykorzystane jako materiał dźwiękoaktywny do poprawy efektywności hipertermii ultradźwiękowej. Przy zastosowaniu nanocząstek magnetycznych mogą one same wytwarzać ciepło w zmiennym polu magnetycznym (magnetyczna hipertermia). Synergetyczne działanie hipertermii ultradźwiękowej i magnetycznej może zwiększyć ilość wytwarzanego ciepła podczas terapii w stosunku do sytuacji, gdy oba rodzaje hipertermii stosowane są oddzielnie.

\section{SP-NT-032: Hybrydowe koniugaty modyfikowanych chlorofili z RNA oraz nanocząstkami metalicznymi dla współczesnej fotomedycyny Michał Kotkowiak ${ }^{1}$, Weronika Kotkowiak², Anna Pasternak², Alina Dudkowiak ${ }^{1}$ \\ (1) Zakład Fizyki Molekularnej, Wydziat Fizyki Technicznej, Politechnika Poznańska, Poznań, Polska \\ (2) Zakład Bioinżynierii Kwasów Nukleinowych, Instytut Chemï Bioorganicznej, PAN, Poznań, Polska}

WPROWADZENIE: W ostatnich latach obserwuje się duże zainteresowanie wykorzystaniem oligomerów RNA/DNA oraz nanocząstek metalicznych (M-NPs) w fotodynamicznej terapii (PDT) i diagnostyce (PDD)1,2. Celem niniejszej pracy było określenie: (i) właściwości fotofizycznych mieszaniny hybrydowej barwniksferyczna M-NPs, w tym wydajności generowania tlenu singletowego $(\varphi \Delta)_{3}$, (ii) wpływu fotoaktywacji koniugatu barwnik-oligomer RNA na jego $\varphi \Delta$ oraz na modyfikację celowanego mRNA w środowisku wodnym. MATERIAŁ I METODA: W badaniach wykorzystano pochodną chlorofilu a (feoforbid a (Pheida)), hematoporfirynę (HP) oraz sferyczne, złote NPs (Au-NPs). Cząsteczki RNA zsyntetyzowano metodą amidofosforynową na podłożu stałym. Oligonukleotyd komplementarny do fragmentu docelowej cząsteczki mRNA poddano postsyntetycznej modyfikacji w celu uzyskania koniugatu z barwnikiem. Układy hybrydowe badano z wykorzystaniem spektroskopii absorpcyjnej oraz fluorescencyjnej, a $(\varphi \Delta)$ wyznaczono wykorzystując 
reakcję fotoutleniania wygaszaczy tlenu singletowego $(1 \Delta \mathrm{g})$. Fragment docelowej cząsteczki mRNA po hybrydyzacji z koniugatem Pheida-oligomer RNA i naświetlaniu, poddano analizie z wykorzystaniem elektroforezy w żelu poliakrylamidowym oraz wysokosprawnej chromatografii cieczowej (HPLC).

WYNIKI: Badania pokazały, że oddziaływanie fotouczulaczy (Pheida lub HP) z Au-NPs silnie wpływa na właściwości fotofizyczne mieszaniny hybrydowej, m.in. przekazywanie energii (pomiędzy barwnikiem a Au-NPs) oraz kwantową wydajność fluorescencji. Ponadto, pokazano możliwość modyfikacji $(\varphi \Delta)$ poprzez zmianę stężenia Au-NPs. Analiza elektroforetyczna oraz HPLC układu Pheida-oligomer zhybrydyzowany z fragmentem mRNA wykazała, że w wyniku naświetlania powstaje produkt reakcji będący skutkiem ekspozycji RNA na działanie $1 \Delta \mathrm{g}$, co może prowadzić do utraty pierwotnych właściwości biologicznych docelowej cząsteczki mRNA.

WNIOSKI: Pokazano możliwość modyfikowania właściwości fotofizycznych oraz kontrolowania $\varphi \Delta$ w układach hybrydowych na bazie fotouczulaczy oraz sferycznych M-NPs oraz korzystny wpływ fotoaktywacji Pheida na modyfikację celowanego mRNA w środowisku wodnym. Badania potwierdziły potencjał tego typu układów jako specyficznych i skutecznych proleków w PDD i/lub PDT.

\section{SP-NT-033: Zastosowanie liposomów jako nośników biologicznie czynnych związków wanadu} Barbara Pytel ${ }^{1}$, Agata Wójcik ${ }^{1}$, Ireneusz Mrówka ${ }^{1}$, Dariusz Man ${ }^{1}$

(1) Uniwersytet Opolski, Instytut Fizyki, Opole, Polska

WPROWADZENIE: Wanad jest pierwiastkiem koniecznym do właściwego funkcjonowania ludzkiego organizmu. Jednak związki wanadu użyte powyżej pewnych stężeń są dla żywych organizmów toksyczne. Badane są zarówno właściwości kancerogennie jak i przeciw-nowotworowe wanadu. Ponieważ działa on zarówno na komórki chore jak i zdrowe, trwają prace nad montowaniem związków wanadu do liposomów. Zapewniając ukierunkowany transport substancji aktywnych, liposomy chronią zdrowe tkanki, zmniejszając uboczne efekty jego działania. Skuteczność działania wanadu zależy m. in. od sposobu podania, zastosowanej dawki oraz czasu trwania doświadczenia. Ale przede wszystkim zależy od wartościowości wanadu oraz rodzaju ligandu, z którym tworzy on związek. Z literatury wiadomo, że kompleks wanadu(IV) z acetyloacetonem wyróżnia się z pozostałych związków wanadu wysoką aktywnością, a jednocześnie niską toksycznością. Celem pracy, było zbadanie wpływu kompleksu wanadu(IV) z acetyloacetonem VO(acac)2 (Sigma Aldrich), na płynność błon liposomów wytworzonych z dipalmitoilofosfa-tydylocholiny DPPC (Sigma Aldrich). Do badań zastosowano technikę elektronowego rezonansu paramagnetycznego (EPR).

MATERIAŁ I METODA: Liposomy uformowano w procesie sonikacji lecytyny DPPC w środowisku wodnym. W eksperymencie, zastosowano sondę spinową 2,2,6,6-tetramethylpiperidine-1-oxyl TEMPO (Sigma Aldrich), która może znajdować się częściowo w środowisku wodnym i częściowo w obszarze hydrofobowym. Do wodnej dyspersji liposomów, wprowadzano kompleks wanadu(IV) w stosunku do lecytyny: $1 \%$ oraz 2,2\%, a następnie wytrząsano. Widma EPR rejestrowano przez 5oh. Analiza wyznaczonego na podstawie otrzymanych widm współczynnika podziału sondy dostarczyła informacji o dynamicznych właściwościach badanej błony, pod wpływem czasu oddziaływania kompleksu VO(acac)2 na dwuwarstwę.

WYNIKI: Po upływie 5oh eksperymentu, nie zaobserwowano istotnych zmian płynności dwuwarstwy pod wpływem działania kompleksu wanadu(IV) o stężeniu 1\%. Natomiast kompleks o stężeniu 2,2\% spowodował nieznaczny wzrost płynności powierzchniowej warstwy błony.

WNIOSKI: Na podstawie przeprowadzonych badań możemy wyciągnąć wniosek, że kompleks wanadu (IV) z acetyloacetonem o stężeniu 2,2 \% w stosunku do lecytyny, może migrować do środka błony. Jego przenikanie mogą ułatwiać właściwości amfifilowe tego kompleksu, co potwierdzają inne badania [1,2].

[1] Olchawa R, Man D, Pytel B (2015) Nukleonika 6o(3): 395-398.

[2] Kotchevar AT, Ghosh P, Uckun FM (1998) J Phys Chem102: 10925-30.

SP-NT-034: Kompozyty polimerowe modyfikowane nanomagnetytem dla zastosowań medycznych

Katarzyna Nowicka ${ }^{1}$, Anna Krak ${ }^{1}$, Henryk Figiel ${ }^{2}$ 
(1) AGH Akademia Górniczo-Hutnicza w Krakowie, Wydział Inżynierii Materiałowej i Ceramiki, Kraków, Polska

(2) AGH Akademia Górniczo-Hutnicza w Krakowie, Wydział Fizyki i Informatyki Stosowanej, Kraków, Polska

WPROWADZENIE: Celem przeprowadzonych badań było określenie możliwości zastosowania polimerowych implantów kompozytowych modyfikowanych magnetytem w obrazowaniu MRI. W badaniach wykorzystano kompozyty o różnym stężeniu magnetytu. Wykonano charakterystykę termiczną oraz, dla części kompozytów, obrazowanie rezonansowo - magnetyczne.

MATERIAŁ I METODA: W badaniach wykorzystano polimery stosowane w medycynie zarówno biodegradowanle i jak i biostabilne. Materiały te były modyfikowane magnetytem o uziarnieniu naometrycznym (Fe3O4). Polimerem biodegradowalnym był polilaktyd, natomiast polimerem biostabilnym był poliuretan. Charakterystykę termiczną materiałów kompozytowych wykonano przy użyciu aparatu Mettler-Toledo DSC 1, właściwości magnetyczne scharakteryzowano wykorzystując magnetometr wibracyjny typ 7407 firmy LakeShore, który znajduje się Akademickim Centrum Materiałów i Nanotechnologii AGH. Obrazowanie magnetyczno - rezonansowe wykonano z użyciem systemu Cirrus Open 0,2T.

WYNIKI: Charakterystyka termiczna kompozytów zarówno tych wykonanych na bazie polilaktydu jak i poliuretanu nie wykazała znacznych różnic w temperaturze zeszklenie i krystalizacji. Obrazy magnetyczno

- rezonansowe uzyskane dla kompozytu na bazie polilaktydu modyfikowanego nanomagnetytem wykazały wpływ stężenia na jakość obrazów oraz wielkość artefaktów. Wyniki pomiarów pola koercji z użyciem magnetometru wibracyjnego dla wyjściowego proszku magnetytu oraz dla kompozytu były bardzo zbliżone (o,0111 T).

WNIOSKI: Jakość obrazów uzyskanych obrazowaniu magnetyczne - rezonansowym zależy od stępienia modyfikatora w kompozycie. Im wyższe stężenie tym zaburzenia obrazu były większe. Wartości namagnesowania nasycenia oraz remanencji były zależne od ilości zastosowanego dodatku.

Celem dalszych badań będzie charakterystyka rezonansowo - magnetyczna modyfikatora w różnych matrycach polimerowych i próba optymalizacji dodatku magnetytu.

\section{SP-NT-035: Nanokompozyty poliacetalowe modyfikowane funkcjonalizowaną ceramiką bioaktywną - otrzymywanie i charakterystyka \\ Katarzyna Nowicka ${ }^{1}$, Paula Szuba ${ }^{1}$, Klaudia Król ${ }^{1}$, Piotr Szatkowski ${ }^{1}$, Kinga Pielichowska ${ }^{1}$ \\ (1) AGH Akademia Górniczo-Hutnicza w Krakowie, Wydział Inżynierii Materiałowej i Ceramiki, Kraków, Polska}

WPROWADZENIE: Prowadzone badania miały na celu modyfikację poliacetali funkcjonalizowanym nanonapełniaczem w oparciu o hydroksyapatyt (HAp) otrzymanym poprzez szczepienie diolu poli(kaprolaktonu) (PCL) na powierzchni HAp przy użyciu łącznika izocyjanianowego. Otrzymane materiały scharakteryzowano metodami spektroskopowymi oraz przeprowadzono badania właściwości termicznych.

MATERIAŁ I METODA: Nanohydroksyapatyt został poddany procesowi funkcjonalizacji poprzez zaszczepienie na jego powierzchni łańcuchów PCL za pomocą 1,6-heksametylenodiizocyjanianu (HDI) w celu otrzymania układu hybrydowego organiczno-nieorganicznego HAp-graft-PCL. Funkcjonalizowny HAp został wprowadzony do poliacetalu metodą przetwórstwa ze stopu. Strukturę otrzymanego HAp-graftPCL potwierdzono metodą spektrofotometrii w podczerwieni. Właściwości termiczne badano za pomocą różnicowej kalorymetrii skaningowej (DSC) oraz metodą termograwimetryczną (TG).

WYNIKI: Badania spektroskopowe potwierdziły skuteczne zaszczepienie PCL na powierzchni HAp. Zaobserwowano znaczny wpływ funkcjonalizacji HAp na właściwości termiczne matrycy poliacetalowej.

WNIOSKI: Zaproponowana metoda otrzymywania hybrydowego materiału nieorganiczno - organicznego jest skuteczną metodą modyfikacji HAp. Tak zmodyfikowany HAp może stanowić bioaktywny dodatek do polimerowych materiałów implantacyjnych poprawiając ich właściwości termiczne, mechaniczne oraz bioaktywność.

[Praca wykonana w ramach projektu badawczego nr DEC-2016/21/B/ST8/00449 finansowanego przez Narodowe Centrum Nauki]. 
SP-NT-036: Lipopleksy na bazie surfaktantów polikationowych i pochodnych enhancera genu DMPK w dystrofii miotonicznej typu pierwszego (DM1)

Weronika Andrzejewska1, Michalina Wilkowska', Maciej Kozak ${ }^{1,2}$

(1) Wydzial Fizyki, Uniwersytet im. Adama Mickiewicza w Poznaniu, Polska

(2) Środowiskowe Laboratorium Badań Strukturalnych, Uniwersytet im. Adama Mickiewicza w Poznaniu, Polska

WPROWADZENIE: Dystrofia miotoniczna typu pierwszego zwana także miotonią zanikową to jedna z wielu nieuleczalnych dotąd chorób. Jej przyczyną jest mutacja genu DMPK powodująca powstawanie i gromadzenie się w komórkach patologicznego mRNA, które zaburza procesy splicingu 1. Skuteczną możliwością leczenia jest celowane działanie terapeutyczne na poziomie genomu poprzez wprowadzenie sekwencji wyciszających. Jednakże stosowane dotąd metody transferu materiału genetycznego do komórek nie są satysfakcjonujące. W tej sytuacji głównym celem badań jest opracowanie i scharakteryzowanie odpowiednich czynników transfekcyjnych (nośników), które będą mogły być wykorzystywane do transfekcji oligomerów siRNA.

MATERIAŁ I METODY: Obiecujące wydają się być lipopleksy stworzone na bazie odpowiednio zaprojektowanych surfaktantów dikationowych i trikationowych. Układy te przez związanie cząsteczek kwasu nukleinowego mogą w nieinwazyjny sposób umożliwić transfer transgenu do wnętrza komórek patologicznych. W niniejszych badaniach jako potencjalny transgen wykorzystano 21-mer siRNA oraz komplementarny dsDNA o sekwencji odpowiadającej części enhancera genu DMPK (DM1). Otrzymane lipopleksy scharakteryzowano w celu określenia wymaganych do związania kwasu nukleinowego parametrów, określenia struktury i symetrii lipopleksów, wykazania zachodzących na skutek kompleksowania zmian konformacyjnych oligomerów, a także określenia nietoksycznych dla komórek żywych stężeń tych układów. Do tego celu wykorzystano metodę elektroforezy żelową, spektroskopii dichroizmu kołowego, małokątowego rozpraszania promieniowania synchrotronowego oraz metody mikroskopowe. Ponad to wykonano testy toksyczności na linii komórek nowotworowych HeLa.

WYNIKI: Wykazano, iż stosując przyjętą metodykę procesu kompleksowania oligomerów z surfaktantami oligokationowymi udaje się uzyskać stabilne lipopleksy. Układy te w zależności od stężenia czynnika amfifilowego formują w roztworach często współistniejące struktury lamelarne, heksagonalne oraz regularne. Związane w lipopleksach oligomery charakteryzują skomplikowane zmiany konformacyjne pozwalające na prześledzenie dynamiki molekularnej procesu kompleksowania. Zoptymalizowano również parametry inkubacji komórek HeLa w środowisku stworzonych lipopleksów.

WNIOSKI: Dzięki przeprowadzonym badaniom stworzono i wstępnie scharakteryzowano potencjalne układy do transfekcji terapeutycznych oligomerów w terapii DM1. Ponad to lipopleksy te są obiecujące pod względem wykorzystania ich jako uniwersalnych nośników w terapii genowej.

\title{
Sesja plakatowa: Biosygnały [SP-BS]
}

\author{
SP-BS-037: Analiza EKG i fali pulsu wysokiej rozdzielczości syngnałowej u osób z chorobami \\ układu krążenia \\ Kinga Graczyk ${ }^{1}$, Aleksandra Boberska - Marek¹, Agata Gronowska ${ }^{1}$, Weronika Kijeska ${ }^{1}$, Dawid Łyko ${ }^{1}$, \\ Joanna Maksim¹, Marika Musielak ${ }^{1}$, Anna Odważna ${ }^{1}$, Klaudia Suszczewicz ${ }^{1}$, Klaudia Turkowiak ${ }^{1}$, Monika \\ Woźny ${ }^{1}$, Bernadeta Dobosz ${ }^{1}$, Ryszard Krzyminiewski ${ }^{1}$ \\ (1) Zakład Fizyki Medycznej, Wydziat Fizyki UAM, Poznań, Polska
}

WPROWADZENIE: Przedstawianie nowych metod diagnostycznych bazujących na standardowym EKG i pulsoksymetrii.

MATERIAŁ I METODA: W Zakładzie Fizyki Medycznej UAM rozwijane są nowe metody diagnostyczne układu krążenia polegające na zwiększaniu rozdzielczości sygnałowej tradycyjnych zapisów EKG (NURSEECG) i fali pulsu (HSR-PW). Zbadano 20 osób z zaburzeniami układu krążenia i przeanalizowano wyniki otrzymane z obu badań. 
WYNIKI: W porównaniu z EKG metoda NURSE-ECG pozwala uzyskać dokładniejsze informacje o aktywności elektrycznej i małych zmianach pojawiających się w pracy serca. Wyniki są przedstawiane w postaci graficznej.

Z kolei metoda HSR-PW oprócz standardowo otrzymanych wyników tętna oraz saturacji pozwala uzyskać informacje o stanie tętnic i zastawek. Również w tej metodzie wyniki przestawiane są w postaci graficznej, co jest czytelne nie tylko dla specjalisty, a także dla pacjenta.

WNIOSKI: Obie te metody dają pełny obraz o stanie całego układu krążenia. Ponadto mogą być wykorzystywane w telemedycynie ze względu na łatwość użytkowania. Diagnostyka jest bardzo szeroka, a przeprowadzona nieinwazyjnie i w krótkim czasie.

\section{SP-BS-038: Badanie poznawczych potencjałów wywołanych mózgu (ERP) na podstawie fali P300 w grupie studentów Karina Maciejewska ${ }^{1,2}$, Zofia Drzazga ${ }^{1,2}$ \\ (1) Zakład Fizyki Medycznej, Instytut Fizyki, Uniwersytet Ślq̨ski, Katowice, Polska \\ (2) Śląskie Międzyuczelniane Centrum Edukacji i Badań Interdyscyplinarnych, Katowice, Polska}

WPROWADZENIE: Celem pracy było zbadanie topografii potencjału elektrycznego fali uwagi (P30o) zmierzonego na powierzchni głowy po stymulacji wzrokowej oraz porównanie go w grupie kobiet i mężczyzn. MATERIAL I METODA: Przebadano 20 zdrowych studentów (w tym 10 kobiet i 10 mężczyzn), z prawidłowym lub skorygowanym do normy wzrokiem, nie zgłaszających zaburzeń neurologicznych. Eksperyment wykonano z wykorzystaniem układu badawczego do akwizycji i analizy EEG/EP Asalab (ANT) z 32 elektrodami w rozszerzonym układzie rozszerzonego montażu 10/20. Do stymulacji użyto paradygmatu typu oddball, wyświetlając bodźce częste (standard) oraz rzadkie (target), przy czym badani mieli reagować na target poprzez naciśnięcie przycisku. Bodźcem standardowym był czarny kwadrat na białym tle, a targetem - białe koło na czarnym tle. Zapisy EEG poddano przetwarzaniu, a uzyskane amplitudy oraz latencje otrzymanej fali P300 zostały poddane analizie statystycznej ANOVA z uwzględnieniem interakcji zmiennych: elektroda pomiarowa oraz płeć.

WYNIKI: W wyniku eksperymentu zaobserwowano m.in. występowanie pozytywnego załamka P30o związanego z uwagą. Najwyższą amplitudę oraz najmniejszą latencję fali P30o zarejestrowano dla odprowadzeń Pz i POz, czyli obszaru ciemieniowego i ciemieniowo-potylicznego wzdłuż linii centralnej. Kobiety wykazały większą niż mężczyźni amplitudę oraz latencję fali P3oo w odprowadzeniach ciemieniowych i ciemieniowo-potylicznych, natomiast mniejszą amplitudę w odprowadzeniach czołowo-centralnych i centralnych. W odprowadzeniach czołowo-centralnych i centralnych zaobserwowano asymetrię różnic latencji ze względu na płeć.

WNIOSKI: W wyniku stymulacji wzrokowej mózgu wywołano falę P300, która jest wynikiem poznawczych funkcji mózgu związanych z uwagą. Pozytywnie wychylona fala P30o została zarejestrowana w rozległych obszarach, a maksymalna amplituda oraz najkrótsza latencja zostały zaobserwowane w odprowadzeniach centralno-ciemieniowych, ponieważ generacji fali P300 przypisuje się złożony zespół źródeł w różnych obszarach mózgu, choć wkład do powstawania sygnału mają głównie: hipokamp, bruzda skroniowa górna, bruzda śródciemieniowa oraz obszar skroniowo-ciemieniowy. Widoczna była lekka asymetria w wartościach amplitudy (większa w półkuli prawej) oraz latencji (krótsza w półkuli prawej) w grupie badanych osób. Zaobserwowano również różnice w amplitudzie i latencji między kobietami a mężczyznami.

\section{Sesja plakatowa: Ochrona Radiologiczna [SP-OR]}

\section{SP-OR-039: Ogień z wodą - czyli o optymalizacji głowicy terapeutycznej mobilnego akceleratora do radioterapii śródoperacyjnej Przemysław Adrich ${ }^{1}$}

(1) Narodowe Centrum Badań Jądrowych, Świerk, Polska 
WPROWADZENIE: Głowica terapeutyczna mobilnego akceleratora elektronów do radioterapii śródoperacyjnej (IOERT) musi łączyć szereg sprzecznych wymagań, tak by aparat mógł być zarazem ergonomiczny i bezpieczny w użytkowaniu na sali operacyjnej. Np. powinna być krótka i lekka ale jednocześnie zapewniać bardzo niski poziom promieniowania ubocznego. Innymi słowy, wydaje się, że konstruując taki układ trzeba połączyć ogień z wodą.

W NCBJ trwają prace nad budową pierwszego polskiego mobilnego akceleratora do IOERT. We wczesnej wersji demonstracyjnej akceleratora uzyskano wiązki terapeutyczne o bardzo dobrych parametrach ale układ formowania był stosunkowo ciężki jak na urządzenie mobilne a poziom promieniowania ubocznego nie był satysfakcjonujący. Dlatego też celem tej pracy było zbadanie możliwości optymalizacji układu w kierunku jednoczesnej minimalizacji masy i dawki od promieniowania ubocznego.

MATERIAŁ I METODA: Do badania modeli obliczeniowych układu formowania wiązki użyto metody symulacji Monte Carlo, z wykorzystaniem pakietu Geant4. Na modelu rzeczywistym wykonano pomiary rozkładów dawki w polu oraz dawki od promieniowania X ubocznego poza polem i poza płaszczyzną pacjenta. W tych ostatnich użyto komory jonizacyjnej dedykowanej do pomiarów środowiskowych.

WYNIKI: Na podstawie badań modeli obliczeniowych zaproponowano oryginalną koncepcję budowy układu kolimacji wiązki. Skonstruowany z wykorzystaniem tej koncepcji prototyp układu formowania, o masie własnej zaledwie niecałych $6 \mathrm{~kg}$ oraz odległości SSD ok. $60 \mathrm{~cm}$, zapewnia bardzo dobre parametry wiązek terapeutycznych w szerokim zakresie energii (4 - 12 MeV) a jednocześnie poziom promieniowania X ubocznego jest ok. 500 do 1000 razy mniejszy niż wymaga norma PN-EN-60601-2-1.

WNIOSKI: Możliwym jest zbudowanie układu formowania wiązki elektronowej, który jednocześnie jest lekki, krótki, zapewnia bardzo niski poziom dawki od promieniowania ubocznego oraz bardzo dobre parametry wiązek terapeutycznych. Opracowane rozwiązanie stanowi istotną przewagę konkurencyjną budowanego w NCBJ pierwszego polskiego mobilnego akceleratora dedykowanego do IOERT (obecnie trwają badania prototypu tego akceleratora; równolegle podjęto kroki w kierunku certyfikacji i opracowania wersji komercyjnej aparatu).

\section{SP-OR-040: Medyczne procedury rentgenodiagnostyczne kobiety w ciąży: podejście międzynarodowe a obecne procedury wzorcowe}

Agnieszka Kuchcińska ${ }^{1}$

(1) SZEDAR Laboratorium Badawcze, Polska

WPROWADZENIE: Celem pracy jest analiza podejścia do ochrony radiologicznej kobiet w ciąży poddawanych procedurom z zakresu rentgenodiagnostyki obrazowej zawartych w procedurach wzorcowych $\mathrm{z}$ dnia 10.11.2015 roku pod kątem ich adekwatności w stosunku do rzeczywistego ryzyka związanego z wykonaniem wybranych procedur versus korzyści z ich wykonania, z uwzględnieniem podejścia międzynarodowego. Celem pośrednim jest analiza konieczności zaangażowania Eksperta Fizyki Medycznej w procedury rentgenodiagnostyczne celem zapewnienia właściwego podejścia do ochrony radiologicznej kobiet w ciąży tym samym zabezpieczenie dostępu do procedur diagnostycznych tej grupie pacjentów.

MATERIAŁ I METODA: W ramach materiału badawczego analizowano raporty, dokumenty oraz materiały szkoleniowe: Międzynarodowej Komisji ds. Ochrony Radiologicznej (ICRP), Międzynarodowej Agencji Energii Atomowej (IAEA), promowanych przez komisję europejską poprzez szkolenie ekspertów fizyki medycznej EUTEMPE-RX. Analizowano raportowane poziomy dawek na płód dla wybranych procedur z zakresu rentgenodiagnostyki obrazowej versus kryteria narażenia płodu (skutki deterministyczne i stochastyczne) w zależności od dawki promieniowania. Badano zgodność (lub jej brak) w uzasadnieniu i rekomendowaniu odpowiednich procedur diagnostycznych w materiałach międzynarodowych oraz polskich procedurach wzorcowych.

WYNIKI: Przeanalizowano raporty ICRP oraz materiały szkoleniowe EUTEMPE-RX. Stwierdzono, że większość procedur diagnostycznych wiąże się z poziomami dawek znacznie poniżej 10omGy uznanych za wartość bezpieczną. IAEA podaje, że diagnostyczne procedury radiologiczne w większości przypadków są bezpieczne nawet podczas ciąży oraz podkreśla, że nie należy unikać badania, jeśli jest ono ważne dla 
zdrowia. Obwieszczenie Ministra Zdrowia z dnia 10.11.2015 zawierające nowelizację procedur wzorcowych radiologicznych z zakresu radiologii i diagnostyki obrazowej zawiera zapis o przeciwwskazaniu względnym do wykonania procedury - ciąża, wprowadzając błędne podejście kliniczne personelu zaangażowanego w wykonywanie tychże procedur, dotyczy to w szczególności procedur: 'TK wielu obszarów anatomicznych po urazie wielomiejscowym (jama brzuszna)', wszystkich procedur 'TK głowy' niezależnie od podania środka kontrastowego jak również stomatologicznych.

WNIOSKI: Procedury wzorcowe nie uwzględniają przyjętego przez międzynarodowe organizacje podejścia w zakresie postępowania z kobietami w ciąży. Sytuacja ta powoduje, że zaangażowanie Eksperta Fizyki Medycznej w zakresie Rentgenodiagnostyki i Radiologii Zabiegowej określonego zgodnie z nową dyrektywą 2013/59/EURATOM jest niezbędne do zapewnienia właściwego zrozumienia zasad Ochrony Radiologicznej oraz ich stosowania w działalności klinicznej. Modelowym programem szkolenia nadzorowanym przez komisję Europejską jest EUTEMPE-RX.

\title{
Sesja plakatowa: Teleradioterapia [SP-TT]
}

\author{
SP-TT-041: Czy specjalność w dziedzinie fizyki medycznej powinna zostać podzielona na fizykę \\ $w$ radioterapii i fizykę $w$ diagnostyce? \\ Paweł Kukołowicz ${ }^{1}$, Julian Malicki² \\ (1) Centrum Onkologii - Instytut im. Marii Skłodowskiej-Curie, Warszawa, Polska \\ (2) Wielkopolskie Centrum Onkologii im. Marii Skłodowskiej-Curie, Poznań, Polska
}

WPROWADZENIE: Omówienie zalet i wad szkolenia podyplomowego w dziedzinie fizyki medycznej prowadzonego wspólnie i rozłącznie dla radioterapii i diagnostyki oraz konsekwencje jednego wspólnego oraz dwóch odrębnych dla obu dyscyplin dyplomów specjalisty.

MATERIAŁ I METODA: Przeanalizowano studia przed- i podyplomowe w dziedzinie fizyki i fizyki medycznej w wybranych krajach, ze szczególnym naciskiem na relacje pomiędzy radioterapią i diagnostyką. WYNIKI: Zadania fizyków medycznych w dziedzinie radioterapii obejmują opracowanie i/lub zatwierdzanie planów leczenia, opracowanie planów dozymetrycznych, przeprowadzanie testów jakości, nadzór nad pracami innych grup zawodowych. W wielu krajach fizycy medyczni w radioterapii muszą ukończyć odpowiednie szkolenie po zakończeniu studiów magisterskich w celu uzyskania certyfikatu (dyplomu).

W diagnostyce pojawienie się zaawansowanych technicznie urządzeń zmniejszyło zadania fizyków podczas procedur obrazowania, ale zwiększyło zapotrzebowanie na fizyków w procedurach zapewnienia jakości.

Wiedza, umiejętności i kompetencje.

Liczne organizacje zawodowe i naukowe (w tym AAMP, ASTRO, ESTRO i EFOMP) zdefiniowały kompetencje fizyków medycznych. Kompetencje związane z bezpieczeństwem radiologicznym zostały określone ponadto przez IAEA oraz w aktach prawnych (np. EURATOM).

Niektóre uniwersytety oferują kursy magisterskie z fizyki medycznej. Trudno jednak porównywać wiedzę/ umiejętności zdobyte podczas studiów magisterskich z wyspecjalizowanym szkoleniem podyplomowym.

W niektórych krajach fizycy medyczni muszą posiadać wiedzę fachową z różnych dyscyplin (radioterapii, medycyny nuklearnej, obrazowania diagnostycznego), podczas gdy inne kraje oddzielają te dziedziny przypisując je do odrębnych specjalizacji.

Wspólne czy osobne programy radioterapii i diagnostyki?

Jeśli fizycy mogliby uzyskać certyfikat zarówno z radioterapii jak i diagnostyki poprzez jednolity, wspólny program, specjaliści mogliby przemieszczać się pomiędzy tymi dwiema dziedzinami. Z drugiej strony szkolenie w dwóch jednak różniących się obszarach zmniejsza wiedzę specjalistyczną z powodu ciągłego, szybkiego rozwoju technologicznego $\mathrm{w}$ każdej z tych dziedzin. Jednym z potencjalnych rozwiązań jest wymaganie ustawicznego kształcenia po zakończeniu specjalizacji w obu dyscyplinach, ale może to być nie praktyczne.

Wartość wspólnego szkolenia dla fizyków radioterapii.

Obrazowanie odgrywa kluczową rolę w radioterapii, zrozumienie różnych sposobów obrazowania 
w planowaniu leczenia w konkretnych przypadkach jest bardzo istotne. Jednak dogłębna i aktualna wiedza w dziedzinie diagnostyki będzie łatwiej osiągalna podczas uczestnictwa w modułach szkoleniowych ukierunkowanych na diagnostykę.

WNIOSKI: Wspólne szkolenie i wspólny dyplom specjalisty zarówno w dziedzinie diagnostyki, jak i radioterapii umożliwiają specjalistom wykonywanie pracy klinicznej w obu dyscyplinach. Takie rozwiązanie jest celowe dla fizyków w radioterapii, którzy powinni posiadać wiedzę w zakresie diagnostyki obrazowej, która jest użyteczna w planowaniu radioterapii i w dozymetrii. Trudne natomiast może być dla fizyków medycznych pracujących tylko w jednej dyscyplinie nadążanie za rozwojem technologii i nauki w obu dziedzinach. Z tego powodu programy kształcenia ustawicznego powinny koncentrować się na treści specyficznej dla danej dyscypliny.

SP-TT-042: Poprawa jakości w radioterapii poprzez zastosowanie audytu klinicznego - IROCA (Improving Radiation Oncology through Clinical Audits)

Magdalena Fundowicz ${ }^{1}$, Maria Glòria Torras ${ }^{2}$, Piotr Milecki ${ }^{1}$, Ewelina Konstanty ${ }^{1}$, Marta KruszynaMochalska ${ }^{1,3}$, Dorota Zwierzchowska ${ }^{1}$, Marco Krengli ${ }^{4}$, Letizia Deantonio ${ }^{4}$, Gianfranco Loi ${ }^{4}$, Luisa Carvalho $^{5}$, Carla Lopes Castro ${ }^{5}$, Joana Lencart ${ }^{5}$, Josep Jove ${ }^{2}$, Ferran Guedea ${ }^{2}$

(1) Wielkopolskie Centrum Onkologii, Poznań, Polska

(2) Institut Català d'Oncologia; L|'Hospitalet, Barcelona, Spain

(3) Uniwersytet Medyczny, Poznań, Polska

(4) Università degli Studi del Piemonte Orientale (UNIUPO), Novara, Italy

(5) Instituto Português de Oncologia, Porto, Portugal

WPROWADZENIE: Badanie ma charakter międzynarodowego badania retrospektywnego, w którym udział biorą badacze z czterech ośrodków z Wielkopolskiego Centrum Onkologii (WCO) w Poznaniu, Institut Catala d'Oncologia (ICO) w Barcelonie, Portuguese Institute of Oncology (IPO) w Porto i z University Hospital Maggiore della Carita (UPO) w Novarze. Obecnie nie ma międzynarodowych standardów kontroli jakości w radioterapii, przeprowadzono kilka audytów klinicznych, ale nie ustalono żadnych wytycznych.

Celem projektu jest przeprowadzenie audytów klinicznych zgodnie z opracowanym kwestionariuszem w czterech ośrodkach: w Wielkopolskim Centrum Onkologii (WCO) w Poznaniu, w Institut Catala d'Oncologia (ICO) w Barcelonie, Portuguese Institute of Oncology w Porto i w University Hospital Maggiore della Carita w Novarze.

MATERIAŁ I METODA: Do projektu zostali zakwalifikowani pacjenci chorzy na raka prostaty i raka jelita grubego leczeni w 2015 roku (80 pacjentów z każdego ośrodka). Nowotwory te zostały wybrane ze względu na wysoką częstotliwość występowania. W pierwszym etapie opracowano kwestionariusz obejmujący diagnostykę pacjentów z chorobą nowotworową, planowanie leczenia, czas leczenia, kontrolę pacjenta w trakcie i po radioterapii oraz aspekty fizyczne takie jak: obrazowanie w teleradioterapii, weryfikacja pól i dawek. W drugim etapie zaplanowano przeprowadzenie 4 audytów klinicznych w ośrodkach: WCO, ICO, UPO i IPO.

WYNIKI: Grupa 14 radioterapeutów, 8 fizyków medycznych oraz 6 pracowników administracyjnych zajmujących się kontrolą jakości z każdego ośrodka opracowała 3 formularze zawierające wskaźniki przeprowadzanych audytów: główny (110 pytań) i dotyczące poszczególnych lokalizacji (odbytnicy - 135 pytań, prostaty - 132 pytań) oraz określiła krytyczne parametry mające wpływ na jakość realizowanej procedury radioterapii (indykatory: 24 ogólne i po 25 dla każdej lokalizacji). W lutym-marcu 2017 wykonano audyty kliniczne w WCO i ICO. Po zakończeniu pozostałych 2 audytów w UPO i IPO analizie zostaną poddane wyniki przeprowadzonych audytów klinicznych pod kątem wybranych parametrów krytycznych i na ich podstawie zostaną stworzone jednolite procedury standardowe w radioterapii dla wszystkich partnerów projektu.

WNIOSKI: Międzynarodowe audyty kliniczne przyczynią się do promocji funkcji audytów klinicznych, a uzyskane wyniki poprzez porównanie do innych ośrodków europejskich, umożliwią osiągnięcie optymalnej kontroli jakości w radioterapii. 
SP-TT-043: Radioterapia zmian skórnych rejonu głowy i szyi z zastosowaniem indywidualych bolusów przygotowanych na drukarce $3 \mathrm{D}$

Magdalena Lukowiak ${ }^{1,2}$, Marek Boehlke ${ }^{1}$, Marzena Więcko ${ }^{1}$, Karolina Jezierska ${ }^{3}$, Mirosław Lewocki ${ }^{1}$, Waldemar Kot $^{1}$, Bogdan Torbe ${ }^{4}$

(1) Zakład Fizyki Medycznej, Zachodniopomorskie Centrum Onkologii w Szczecinie, Polska

(2) Oddział Kliniczny Radioterapii, Pomorski Uniwersytet Medyczny w Szczecinie, Polska

(3) Zakład Fizyki Medycznej, Pomorski Uniwersytet Medyczny w Szczecinie, Polska

(4) Oddział Kliniczny Radioterapii, Pomorski Uniwersytet Medyczny w Szczecinie, Polska

WPROWADZENIE: W pracy prezentowana jest metoda wytwarzania oraz weryfikacji bolusów indywidualnych przygotowanych przy użyciu technologii trójwymiarowego drukowania u pacjentów z nowotworami skóry, zakwalifikowanymi do radioterapii.

MATERIAŁ I METODA: Dla 20 pacjentów ze zmianami skórnymi rejonu głowy i szyi: 5 w obszarze skóry nosa, $3 \mathrm{w}$ obszarze ucha, $3 \mathrm{w}$ obszarze skroni oraz $9 \mathrm{w}$ obszarze wewnętrznego kącika oka - w systemie planowania leczenia zaplanowano kształt bolusa indywidualnego, który następnie oddtworzono za pomocą drukarki 3D. Na drukarce 3D wydrukowano formę bolusa, którą następnie wypełniono wodą bądź woskiem - celem otrzymania jednorodności na poziomie średniej gęstości tkanki miękkiej 1 g/cm3 .

Dla każdego bolusa wykonano tomografię komputerową, której obraz nałożono na tomografię komputerową pacjenta z bolusem referencyjnym - zaplanowanym w systemie planowania leczenia.

Dane otrzymane z fuzji obrazów wykorzystano do zweryfikowania kształtu wydrukowanego bolusa 3D w odniesieniu do bolusa referencyjnego za pomocą formuły WD (współczynnika dopasowania), której wynik przyjmował wartości pomiędzy o a 100\%, gdzie 100\% wskazywało na idealne dopasowanie bolusa 3D do modelu referencyjnego. Obrazy z tomografii komputerowej posłużyły również do oceny jednorodności bolusów.

Dodatkowo, przy wykorzystaniu fuzji obrazów kształt bolusa 3D przeniesiono do planu leczenia pacjenta, gdzie przy niezmienionych parametrach planu leczenia zasymulowano rozkład dawki otrzymywany w objętości PTV.

Aby przedstawić przewagę bolusów 3D nad manualnymi metodami ich przygotowania, dla wszystkich pacjentów wykonano również bolusy woskowe. Analogicznie przeprowadzono weryfikację ich kształtu oraz symuację rozkladu dawki w odniesieniu do bolusa referencyjnego.

WYNIKI: Sprawdzono, że wartości WD dla bolusa 3D mieściły się w zakresie 83 - 100\%, natomiast dla bolusa woskowego WD przyjmował wartości w zakresie $23-73 \%$.

Średnia z rożnic w rozkładzie dawki pomiędzy planem z bolusem 3D a bolusem referencyjnym nie przekraczała 1\%. Dla porównania, średnia z rożnic w rozkładzie dawki orzymana dla bolusów woskowych wynosiła 3\% w stosunku do planu referencyjnego.

WNIOSKI: Badania pokazują, że zastosowanie technologii trójwymiarowego drukowania ma co najmniej trzy zalety, które zwiększają dokładność dostarczenia dawki terapeutycznej w obszar nowotworowy zgodnie z przygotowanym planem leczenia. Po pierwsze kształt bolusa $3 \mathrm{D}$ jest zgodny z bolusem referencyjnym. Po drugie bolusy 3D przylegają do krzywizny ciała pacjenta nie powodując powstawania wnęk powietrznych pomiędzy powierzchnią bolusa i ciałem pacjenta. Ostatnią przewagą jest jego jednorodność.

SP-TT-044: Długoterminowa analiza wyników pomiarów dwuwymiarowych rozkładów dawki w codziennej kontroli jakości skanującej wiązki protonowej Wiktor Komenda ${ }^{1}$, Dawid Krzempek ${ }^{1}$, Jan Gajewski ${ }^{1}$, Anna Guzik², Liliana Stolarczyk ${ }^{1}$, Renata Kopeć ${ }^{1}$

(1) Instytut Fizyki Jądrowej Polskiej Akademii Nauk, Centrum Cyklotronowe Bronowice, Polska

(2) Akademia Górniczo-Hutnicza, Kraków, Polska

WPROWADZENIE: W Centrum Cyklotronowym Bronowice (CCB IFJ PAN) znajdują się dwa stanowiska terapeutyczne umożliwiające napromienianie nowotworów zlokalizowanych w obrębie całego ciała za pomocą skanującej wiązki protonowej przy wykorzystaniu ramienia obrotowego - gantry. System kontroli jakości zaimplementowany w CCB IFJ PAN zakłada, że codziennie w ramach testów dozymetrycznych sprawdzane 
są m. in. parametry przekroju poprzecznego pojedynczych wiązek protonowych oraz parametry przekroju poprzecznego jednorodnego pola promieniowania: wielkość R, półcienie P, jednorodność J i symetria S.

MATERIAŁ I METODY: Pomiar przekroju poprzecznego jednorodnego pola promieniowania $(5 \mathrm{~cm} \times 5 \mathrm{~cm})$ o energii E $150 \mathrm{MeV}$ oraz przekrojów poprzecznych pojedynczych wiązek protonowych o energiach $\mathrm{E} 70 \mathrm{MeV}$, $150 \mathrm{MeV}$ i $225 \mathrm{MeV}$ wykonywany jest w ramach codziennych testów kontroli jakości przy użyciu detektora scyntylacyjnego Lynx PT (IBA Dosimetry) pozwalającego na akwizycję obrazu o maksymalnych wymiarach $30 \mathrm{~cm} \times 30 \mathrm{~cm}$ z rozdzielczością $0,5 \mathrm{~mm}$. Analiza wyników codziennych pomiarów dwuwymiarowych rozkładów dawki objęła okres 13 miesięcy pracy obu stanowisk gantry.

WYNIKI: Rozmiar wiązki protonowej, rozumiany jako wartości parametru sigma o rozkładu normalnego dopasowanego do profilu poprzecznego wiązki, dla $\mathrm{E}=70 \mathrm{MeV}$ wynosił 6,47mm w osi X oraz 6,64 mm w osi Y dla stanowiska Gantry1 oraz odpowiednio 6,56mm i 6,77mm dla stanowiska Gantry2. Dla $\mathrm{E}=15 \mathrm{O} \mathrm{MeV} \sigma \mathrm{X}=$ $3,93 \mathrm{~mm}$, a $\sigma \mathrm{Y}=4,02 \mathrm{~mm}$ (Gantry1) oraz $\sigma \mathrm{X}=4,05 \mathrm{~mm}$ i $\sigma \mathrm{Y}=3,96 \mathrm{~mm}$ (Gantry2) natomiast dla $\mathrm{E}=225 \mathrm{MeV} \sigma \mathrm{X}$ $=2,49 \mathrm{~mm}$ i $\sigma \mathrm{Y}=2,62 \mathrm{~mm}$ oraz $\sigma \mathrm{X}=2,52 \mathrm{~mm}$ i $\sigma \mathrm{Y}=2,53 \mathrm{~mm}$ odpowiednio dla Gantry1 i Gantry2. Odchylenie standardowe dla tych pomiarów nie przekroczyło o,07 mm. Średnia wartość dwuwymiarowej jednorodności pola dla obu stanowisk terapeutycznych wynosiła $1,2 \% \pm 0,2 \%$, a średnia symetria dwuwymiarowa $\mathrm{Sx}=$ $-0,10 \pm$ 0,03, Sy = -0,05 \pm 0,04 (Gantry1) oraz Sx = -0,06 \pm 0,10, Sy = -0,09 \pm 0,05 (Gantry2).

WNIOSKI: Prowadzone przez okres 13 miesięcy pomiary parametrów wiązki protonowej udowodniły, że systemy ekstrakcji i transportu wiązki są w stanie dostarczać wiązkę protonową do stanowisk terapeutycznych z powtarzalnością lepszą niż $0,1 \mathrm{~mm}$. Jednocześnie zmierzone wartości jednorodności i symetrii potwierdzają, że przy wykorzystaniu skanującej wiązki protonowej możliwe jest otrzymanie wysoce jednorodnych rozkładów dawki.

\section{SP-TT-045: Testy kontroli jakości obrazowania aparatu TrueBeam Maciej Raczkowski ${ }^{1}$, Marzena Janiszewska ${ }^{1}$}

(1) Zakład Fizyki Medycznej, Dolnośląskie Centrum Onkologii we Wroctawiu, Polska

WPROWADZENIE: Krytycznym wymogiem w radioterapii jest dokładność i odtwarzalność leczenia z dnia na dzień. Wczesne badania oparte na filmach radiograficznych wskazywały wyraźne korzyści z weryfikacji obrazowej ułożenia pacjenta. Dalsze badania pozwoliły na scharakteryzowanie wielkość i charakteru błędów w ułożeniu na różnych etapach realizacji radioterapii. Pojawiły się pojęcia takie jaki błąd systematyczny i błąd przypadkowy, a skutecznym sposobem, aby je ograniczyć okazało się zwiększenie częstości weryfikacji obrazowej. Potrzeba ulepszonego systemu obrazowania prowadząca do zwiększenia częstotliwości i dokładności weryfikacji realizacji radioterapii, pobudziła rozwój elektronicznych urządzeń obrazowych dających wynik on-line. Dzisiaj w czasach radioterapii sterowanej obrazem IGRT, dokładność i odtwarzalność leczenia z frakcji na frakcję, bazująca na weryfikacji on-line, protokołach NAL oraz eNAL, jest złotym standardem. Standardem są również testy jakości systemów obrazowania, których poprawność działania determinuje dokładność i odtwarzalność leczenia w czasie.

MATERIAŁ I METODA: Testy kontroli jakości systemu obrazowania akceleratora TreuBeam, opracowane zostały w oparciu o szereg dokumentów w tym obowiązującego w Polsce prawa i przepisów wykonawczych. RMZ z dnia 12 listopada 2015 roku nie wprowadza swoim zakresem testów systemów obrazowania na akceleratorze medycznym, dopuszcza jednak możliwość, zgodnie z brzmieniem ust. 22, stosowania innymi dokumentów w celu opracowania zakresu i częstotliwości wykonywania testów dla urządzeń radiologicznych i pomocniczych innych niż określone w załączniku nr 6 do w/w RMZ.

WYNIKI: Testy obrazowania akceleratora TrueBeam opracowane w DCO, obejmują swoim zakresem: kontrolę jakości obrazów dla systemów MV, kV, CBCT; stabilność pracy generatora kV; dokładność odwzorowania HU; bezpieczeństwo i funkcjonalność; dokładność i precyzję elementów mechanicznych; precyzję ustawienie i korekcji stołu terapeutycznego; poprawność działania algorytmu auto korekcji ustawienia stołu; poprawność rekonstrukcji i dopasowania obrazów; ocenę dawki jaką otrzymuje pacjent.

WNIOSKI: Kontrola jakości systemów obrazowania, które stały się integralną częścią akceleratorów medycznych, ze względu na ich niepodważalny wkład w dokładność i odtwarzalność leczenia w funkcji czasu, jest niezwykle istotnym elementem każdego systemu zapewnienia jakości w radioterapii. Kontrola jakości 
zainicjalizowana podczas testów odbiorczych, powinna zostać przeszczepiona na grunt testów rutynowych, a ich zakres określony w oparciu o charakterystykę danego systemu oraz z uwzględnieniem doświadczenia klinicznego.

\section{SP-TT-046: Metoda weryfikacji prędkości listków w akceleratorze Elekta Synergy z systemem kolimacji MLCi2 \\ Przemysław Wocial' ${ }^{1}$, Marzena Morawska-Kaczyńska ${ }^{1}$}

(1) Centrum Onkologii - Instytut im. Marii Skłodowskiej-Curie, Warszawa, Polska

WPROWADZENIE: Celem pracy jest opracowanie metody weryfikacji prędkości listków oraz sprawdzenie dynamiki systemu kolimacji MLCi2.

W technice IMRT i VMAT precyzja kalibracji i ruchu listków (MLC) mają kluczowe znaczenie dla dokładności dostarczania dawki w obszar tarczowy oraz samego czasu trwania sesji terapeutycznej.

MATERIAŁ I METODA: Do testów dynamiki układu kolimacji MLCi2 firmy Elekta, wyposażonego w 40 par listków o szerokości $1 \mathrm{~cm}$ każdy, wykorzystano moduł graficzny trybu serwisowego akceleratora Synergy firmy Elekta. Z wybraną przez operatora częstością próbkowania akcelerator rejestruje i zapisuje położenia listków w czasie w zbiorze o formacie xml. W programie iComCAT stworzono wiązki testowe w kształcie szczeliny $1 \mathrm{~cm}$ x $40 \mathrm{~cm}$, poruszającej się w zakresie $20 \mathrm{~cm}$ ruchem jednostajnym z prędkością maksymalną lub prędkością około 2.5 razy niższą od maksymalnej. Dla wiązek testowych wykonano pomiary położenia listków dla dwóch częstości próbkowania: $1 \mathrm{~Hz}$ i $4 \mathrm{~Hz}$ oraz dla dwóch położeń ramienia akceleratora: $\mathrm{O}^{0} \mathrm{i} 90^{0}$. W arkuszu kalkulacyjnym obliczano prędkości chwilowe MLC w czasie ich ustabilizowanego ruchu oraz zbadano synchronizację położeń i prędkości listków.

WYNIKI: Maksymalna średnia prędkość chwilowa listków wynosi $20.03 \mathrm{~mm} / \mathrm{s}$ dla kąta ramienia $0^{0}$ i 20.56 $\mathrm{mm} / \mathrm{s}$ dla ruchu MLC w kierunku przeciwnym do grawitacji. Powolniejszy ruch listków charakteryzuje się tylko nieznacznie większą precyzją: rozrzut prędkości poszczególnych listków w czasie t (1SD) jest w zakresie $\pm(0.003-0.006) \mathrm{mm} / \mathrm{s}$ dla maksymalnej prędkości oraz $\pm(0.001-0.002) \mathrm{mm} / \mathrm{s}$ dla prędkości $7.8 \mathrm{~mm} / \mathrm{s}$. Wykorzystywany moduł graficzny nie nadąża z rejestracją pozycji listków z wysoką częstotliwością, szczególnie dla szybko poruszających się listków.

WNIOSKI: Moduł graficzny trybu serwisowego akceleratora Synergy może być wykorzystany do testów synchronizacji ruchu poszczególnych listków oraz badania stabilności prędkości MLC wyłącznie przy stosowaniu niskich częstości próbkowania. Proponowany test wykorzystuje wewnętrzne współrzędne MLC rejestrowane przez akcelerator i nie zastępuje niezależnego testu kalibracji układu MLC.

Prędkości maksymalne MLC są bliskie wartości nominalnej. Wszystkie listki charakteryzują się podobną dynamiką i synchronizacją zarówno w zakresie średnich jaki i najwyższych prędkości ruchu.

\section{SP-TT-047: Kalibracja liczb tomograficznych (HU) z rozszerzoną skalą dla pacjentów z metalowymi implantami Dominika Oborska-Kumaszynska ${ }^{1}$}

(1) The Royal Wolverhampton NHS Trust, MPCE Department, England

WPROWADZENIE: Celem projektu bylo dopuszczenie systemu TK (Philips Brilliance ver.4.2.0.17057) do użytku klinicznego w radioterapii. Częścią projektu było wyznaczenie krzywej kalibracyjnej, wiążącej wartości HU z masową gęstością materiałów. Dane zostały zebrane dla zestawu materiałów z zakresu gęstości wynikających z anatomicznej budowy pacjenta oraz trzech materiałów o wysokiej gęstości dla implantów: aluminium, tytan, stal chirurgiczna.

MATERIAŁ I METODA: Dla wybranych protokołów klinicznych wykonano skany fantomu CIRS, zawierającego materiały symulujące naturalne tkanki ciała pacjenta oraz materiały, używane w implantach (aluminium, tytan, stainless steel). Protokoły wybrano na podstawie rekonstrukcji wykonanych dla fantomu CATPHAN6oo oraz porównaniu uzyskanych HU dla poszczególnych materiałów: mózgowie (filtr UB), głowa-szyja, klatka piersiowa, jama brzuszna, kręgosłup (filtr B). Wyznaczono charakterystyki (gęstość 
masowa $=f(H U)$ dla tych protokołów i z nich średnią. Porównano wyniki dla protokołów ze stałym mAs, ACS i różnych położeń materiałów w CIRS.

WYNIKI: Wyznaczono charakterystyki wiążące gęstość masową z wartościami HU dla poszczególnych materiałów. Wyznaczono wartości średnie dla różnych protokołów i z różnych położeń materiału w CIRS. Położenie materiału w CIRS determinowało zmianę HU dla najgęstszych materiałów: 20HU/gęsta kość, 30HU/aluminium, $\sim 100 \mathrm{HU} / \operatorname{tytan}, \sim 500-700 \mathrm{HU} /$ stal. Maksymalne różnice HU dla protokołów skanowania (w tym ACS i stałe mAs) wynosiły: stal-1395HU, tytan-657HU, aluminium-42HU, pozostałe materialy poniżej 20HU (dla tkanek miękkich poniżej 10HU). Długoterminowa stabilność HU dla najbardziej gęstych materiałów wykazywała znaczący rozrzut wyników $(\sim-163 \mathrm{HU}-+13 \mathrm{HU}$ tytan, $\sim-79-+7 \mathrm{OHU}$ stal), dla pozostalych materialow różnice były mniejsze lub około $20 \mathrm{HU}$.

WNIOSKI: Wyznaczenie średniej charakterystyki z różnych protokołów klinicznych oraz różnych położeń materiałów w fantomie stanowiło najbardziej zoptymalizowane rozwiązanie dla uzyskanych wyników. To pozwoliło na zmniejszenie wpływu niepewności wyznaczenia oraz uzyskanego rozrzutu w wynikach (gęstość masowa)=f(HU). Dla różnych regionów anatomicznych system TK wykorzystuje różne algorytmy rekonstrukcyjne, korektę na rozproszenie, wewnętrzne filtry do wzmocnienia cech obrazu, na które użytkownik nie ma wpływu. Ponadto ustawienia użytkownika dla protokołów są także limitowane regionem anatomicznym. Przyjęcie tego rozwiązania zweryfikowano testatmi end-to-end. Wyniki potwierdziły słuszność przyjętego rozwiązania w zakresie przyjętej tolerancji +/- 1.5\% dla obliczonej vs zmierzonej dawki.

SP-TT-048: Dawka pochłonięta przez lewą tętnicę wieńcową serca ( LAD; Left Arterior Descending) w przypadku pacjentek $\mathrm{z}$ rakiem piersi poddawanych radioterapii w ramach oszczędzającego leczenia

Aleksandra Sobajtis ${ }^{1}$, Joanna Kamińska², Marcin Sinacki², Krystyna Serkies²

(1) Instytut Fizyki Doświadczalnej, Uniwersytet Gdański, Gdańsk, Polska

(2) Klinika Onkologii i Radioterapii Uniwersyteckie Centrum Kliniczne w Gdańsku, Polska

WPROWADZENIE: Celem pracy było określenie dawki pochłoniętej przez LAD w przypadku pacjentek poddanych teleterapii i brachyterapii w ramach oszczędzającego leczenia raka piersi. Ponadto, zasadność wrysowywania tego narządu krytycznego. Ze względu na problem związany z konturowaniem obszaru LAD, podjęto próbę wyznaczenia obszaru serca, który gwarantuje objęcie LAD.

MATERIAŁ I METODA: Grupa badana obejmowała 21 pacjentek z rakiem lewej piersi oraz 20 pacjentek z rakiem prawej piersi. Przeanalizowano plany brachyterapii oraz teleterapii odpowiednio w systemie Oncentra Brachy v 3.3 oraz Eclipse v.13.0 pod kątem rozkładu dawki w LAD na podstawie histogramów DVH. Podczas konturowania serca i LAD, w przypadkach z guzem lewej piersi wprowadzono wewnętrzne marginesy w sercu $0.5 \mathrm{~cm}, 1 \mathrm{~cm}$ i $1.5 \mathrm{~cm}$.

WYNIKI: Dawka średnia w LAD u kobiet na raka lewej piersi wynosiła 0,04 Gy - 0,39 Gy oraz 2,51 - 49,05 Gy odpowiednio podczas brachyterapii i teleterapii.

W przypadkach raka prawej piersi dawka średnia na LAD nie przekraczała $0,1 \mathrm{~Gy}$.

Spośród dziesięciu przeanalizowanych pacjentek z rakiem lewej piersi, obszar LAD zawierał się w obszarze znajdującym się $1 \mathrm{~cm}$ od wewnętrznej ściany serca.

WNIOSKI: Lewa tętnica wieńcowa jest narządem krytycznym otrzymującym niekiedy istotną dawkę, stąd LAD powinna być uwzględniana podczas planowania leczenia raka lewej piersi.

Do oszacowania dawki otrzymanej przez LAD wystarczy ocenić dawkę w obszarze otrzymanym poprzez wrysowania 1-centymetrowego marginesu od wewnętrznej ściany serca.

SP-TT-049: Porównanie techniki VMAT oraz połączenia technik 3D-VMAT pod kątem ograniczenia dawek dla pacjentek $\mathrm{z}$ wbudowanym układem stymulującym serce

Sandra Łukomska' ${ }^{1}$, Paweł Kukołowicz ${ }^{1}$

(1) Zakład Fizyki Medycznej, Centrum Onkologï - Instytut im. Marï Skłodowskiej - Curie w Warszawie, Warszawa, Polska 
WPROWADZENIE: Celem pracy było wybranie optymalnej metody planowania leczenia pacjentek z nowotworami piersi z wbudowanym układem stymulującym serce. Istnieje potrzeba, aby było dla nich możliwe zachowanie maksymalnego objęcia wysokimi dawkami obszaru napromienianego oraz maksymalnego ograniczenia dawek w obszarze poza targetem (zwłaszcza w rejonie generatora i elektrod). Stosowane samodzielnie wysokospecjalistyczne techniki IMRT/VMAT lub konformalne 3D uniemożliwiają jednoczesne spełnienie obu tych warunków.

MATERIAŁ I METODA: W celu realizacji pracy wykonano plany leczenia dla pacjentki z nowotworem lewej piersi po mastektomii z wbudowanym stymulatorem serca po stronie prawej i elektrodami wewnątrz serca. Na początku przygotowano plan 3D złożony z dwóch pól tangencjalnych, gdzie podano 80\% dawki przepisanej. Dla pozostałych $20 \%$ przepisanej dawki utworzono plan IMRT (tomografia wykonana na swobodnym oddechu) oraz VMAT (tomografia na wstrzymanym wdechu). Powstały wcześniej plan 3D służył jako tzw. „Base Dose Plan”- optymalizacja uwzględniała jego rozkład dawki. Otrzymane plany zostały zsumowane dając w rezultacie dwa plany hybrydowe: 3D-IMRT oraz 3D-VMAT. Następnie przygotowano samodzielne plany IMRT oraz VMAT (podając pełną przepisaną dawkę). Analizując plany IMRT, 3D-IMRT, VMAT, 3D-VMAT porównywano objęcie targetu dawką przepisaną, dawki na narządy krytyczne oraz układ stymulujący serce.

WYNIKI: Porównanie planów IMRT oraz 3D-IMRT pokazało, że zastosowanie planu hybrydowego pozwala zmniejszyć dawkę średnią w elektrodach (o 4.4Gy), generatorze (o 0,7Gy), lewym płucu (o 1.3Gy), sercu (o 2.8Gy) oraz sumie płuc (o 2.6Gy). Umożliwia także ograniczenie obszaru sumy płuc objętego niskimi dawkami 5Gy o 37\%. W przypadku porównania VMAT vs. 3D-VMAT, ten ostatni powoduje znaczące obniżenie dawek średnich w elektrodach (o 7Gy), generatorze (o o,8Gy), lewym płucu (o 2.1Gy), sercu (o 5.5Gy), sumie płuc (o 3.3Gy, V5Gy o 42\%). We wszystkich planach 95\% dawki przepisanej obejmowało około 98,5\% objętości targetu.

WNIOSKI: Otrzymane wyniki pokazują, że zastosowanie metody łączenia technik w planowaniu leczenia pozwala osiągać mniejsze dawki na narządy krytyczne i układ stymulujący serce przy jednoczesnym zachowaniu maksymalnego objęcia obszaru napromienianego. Ze względu na obiecujący charakter wyników prowadzone będą dalsze prace na większej grupie pacjentek.

\section{SP-TT-050: Radioterapia pacjentów z wszczepionymi stymulatorami i kardiowerterami - defibrylatorami Artur Hołub ${ }^{1}$}

(1) Centrum Onkologii Ziemi Lubelskiej, Lublin, Polska

WPROWADZENIE: Rozszerzenie wskazań do implantacji układu stymulującego serce w połączeniu ze wzrostem zachorowalności na nowotwory przekłada się na wzrost liczby chorych z wszczepionym stymulatorem (ICP - implantable cardiac pacemaker) lub kardiowerterem-defibrylatorem (ICD - implantable cardioverter-defibrillator) poddawanych radioterapii. W przypadku nowotworów zlokalizowanych w śródpiersiu (np. nowotwory płuc, sutka, chłoniaki) lub w rejonie głowy i szyi radioterapia niesie za sobą zwiększenie ryzyka uszkodzenia tych urządzeń. Również napromienianie nowotworów zlokalizowanych w odległych od stymulatora okolicach ciała wymaga rozważenia wpływu promieniowania jonizującego. Celem pracy jest przedstawienie wytycznych dotyczących radioterapii pacjentów ze stymulatorami serca.

MATERIAŁ I METODA: Analiza opublikowanych wyników badań dotyczących wpływu promieniowania jonizującego na stymulatory serca oraz informacje podawane przez producentów pozwalają na sformułowanie zasad postępowania w przypadku konieczności poddania radioterapii pacjentów z ICP lub ICD.

WYNIKI: Nowoczesne stymulatory serca wykonane w technologii CMOS są wrażliwe na promieniowanie jonizujące $\mathrm{z}$ zakresu emitowanego przez akceleratory terapeutyczne. Wraz ze wzrostem potencjału przyspieszającego, rośnie ryzyko wystąpienia zaburzeń w pracy układów stymulujących. Zależność ta, spowodowana jest niekorzystnym wpływem wtórnego promieniowania neutronowego na elementy półprzewodnikowe. Kardiowertery-defibrylatory tolerują niższe dawki niż ICP, ponadto ich awaria może powodować poważniejsze konsekwencje. Nie zaobserwowano uszkodzeń spowodowanych przez symulatory i tomografy. 
WNIOSKI: Pacjenci z wszczepionym stymulatorem serca mogą być poddawani radioterapii pod warunkiem odpowiedniego monitorowania w trakcienapromienianiai pojego zakończeniu. Odległość międzygeneratorem stymulatora a granicą pola powinna wynosić co najmniej $2 \mathrm{~cm}$. Jeśli obszar napromieniany ma obejmować miejsce wszczepienia urządzenia, konieczne jest jego przeniesienie. Nie należy używać promieniowania fotonowego wytworzonego potencjałem przyspieszającym wyższym niż 6MV. Dawka otrzymywana przez stymulator powinna zostać zmierzona w trakcie pierwszego seansu radioterapii a następnie porównana z obliczoną w systemie planowania leczenia. Sugerowane maksymalne dawki nie powinny przekraczać 2 Gy dla ICP oraz 1 Gy dla ICD.

\section{SP-TT-051: Ocena maksymalnej dawki w obszarze potencjalnego położenia płodu w przypadku kobiet napromienianych podczas ciąży}

Ewelina Węgielska1 ${ }^{1}$ Joanna Kamińska², Krystyna Serkies ${ }^{2}$

(1) Instytut Fizyki Doświadczalnej, Uniwersytet Gdański, Gdańsk, Polska

(2) Klinika Onkologii i Radioterapii Uniwersyteckie Centrum Kliniczne w Gdańsku, Polska

WPROWADZENIE: Celem pracy była ocena maksymalnej dawki w obszarze potencjalnego położenia płodu podczas radioterapii guza nowotworowego o różnej lokalizacji w odniesieniu do tygodnia ciąży.

MATERIAŁ I METODA: Przygotowano 8 planów leczenia z zastosowaniem promieniowania jonizującego w systemie planowania Eclipse v.13.o dla pięciu lokalizacji guza: obszaru głowy, górnego i dolnego odcinka kręgosłupa, płuc oraz żołądka (odpowiednio 2 i 3 plany w zależności od wielkości PTV). W przypadkach nowotworu zlokalizowanego w obszarze głowy zastosowano technikę radykalną 3D, w obszarze kręgów technikę RapidArc oraz IMRT w pozostałych lokalizacjach. Na podstawie histogramów (DVH) oceniono maksymalną dawkę w przyjętych obszarach potencjalnego położenia płodu, tj. w obszarze jamy brzusznej i miednicy do poziomu odpowiadającemu położeniu dna macicy w 20, 24, 28 oraz 36 tygodniu ciąży.

WYNIKI: W obszarze odpowiadającym położeniu płodu w 36 tygodniu ciąży maksymalne dawki wynosiły: - oGy, 0.14Gy, 39.29Gy, odpowiednio przy napromienianiu nowotworu w lokalizacji: głowy, kręgów górnych oraz dolnych .W przypadkach płuca wynosiły one 0.03Gy i o.79Gy - odpowiednio do wielkości obszaru PTV, oraz żołądka 1.84Gy, 48.68Gy i 52.42Gy odpowiednio dla małego, średniego i dużego PTV.

WNIOSKI: Maksymalna dawka jaką potencjalnie otrzymuje płód jest różna w zależności od wielkości guza i trymestru ciąży. W wybranych przypadkach napromieniania regionów głowy, kręgów górnych i płuc narażenie dojrzałego płodu jest minimalne i nie przekracza dawki granicznej na płód - 100mGy.

\section{SP-TT-052: Weryfikacja rozkładu dawki w radioterapii za pomocą antropomorficznych fantomów wytwarzanych na drukarce $3 D$}

Magdalena Łukowiak ${ }^{\mathbf{1} 2}$, Marek Boehlke ${ }^{1}$, Marta Piątek - Hnat ${ }^{3}$

(1) Zakład Fizyki Medycznej, Zachodniopomorskie Centrum Onkologii w Szczecinie, Polska

(2) Oddział Kliniczny Radioterapii, Pomorski Uniwersytet Medyczny w Szczecinie, Polska

(3) Instytut Polimerów, Zakład Biomateriałów i Technologii Mikrobiologicznych, Zachodniopomorski Uniwersytet Technologiczny w Szczecinie, Polska

WPROWADZENIE: W pracy prezentowana jest metoda konstruowania fantomów anropomorficznych przy użyciu technologii trójwymiarowego drukowania, celem indywidualnego podejścia do weryfikacji zaplanowanego w systemie planowania leczenia rozkładu dawki w radioterapii.

MATERIAŁ I METODA: W oparciu o obrazy tomografii komputerowej pacjenta, w systemie planowania leczenia Nucletron Oncentra MasterPlan 4.3 przygotowano modele fantomów w formie warstw, pomiędzy ktorymi umieszczono filmy Gafchromic EBT3. Każda warstwa fantomu została podzielona na fragmenty odpowiadające strukturom o różnych gęstościach tj. tkanka mięśniowa, tkanka tłuszczowa, kość oraz powietrze. Na drukarce ZORTRAX M20o każdy z elementów został wydrukowany jako osobna forma, które następnie połączono ze soba i wypełniono odpowiednimi materiałami przypominającymi środowisko pacjenta. Na podstawie raportu ICRP 23 przygotowano mieszaniny przypominające składem atomowym 
oraz osłabiające wiązkę promieniowania jonizującego w podobny sposób jak tkanka mięśniowa oraz kość. W celu otrzymania odpowiednika tkanki mięśniowej wykorzystano mieszaninę gliceryny z wodą oraz agarem, natomiast do otrzymania odpowiednika kości mieszaninę gliceryny z hydroksyapatytem oraz agarem. Tkankę tłuszczową zastąpono tłuszczem zwierzęcym.

Dla otrzymanych substancji przeprowadzono szereg badań tomograficznych sprawdzających przenikalność promieniowania jonizujacego w odniesieniu do tkanek pacjenta.

Gotowe fantomy został napromienione zgodnie z przygotowanymi planami leczenia a otrzymane rozkłady dawek z filmow Gafchromic porównane za pomoca współczynnika gamma z wynikami otrzymanymi dla korespondujących warstw pacjenta z systemu planowania leczenia.

WYNIKI: Wyniki z tomografii komputerowej (ocena wg. skali Hounsfielda) pokazały, że otrzymane odpowiedniki tkanki mięśniowej i kości z dużą dokladnością naśladują tkanki pacjenta.

Analiza rozkładów dawek pokazała, że dla parametru gamma 3\%, 3mm co najmniej 95 procent punktów spełniało warunek gamma mniejszego od jedności.

WNIOSKI: Dzięki wykorzystaniu technologii trojwymiarowego drukowania mamy możliwość niestandardowego zweryfikowania zaplanowanego w systemie planowania leczenia rozkładu dawki $\mathrm{w}$ fantomie przypominającym indywidualne środowisko pacjenta. Ponieważ fantom konstruowany jest na bazie tomografii komputerowej pacjenta, mamy możliwość pomiaru rozkładu dawki pod różnymi kątami - zgodnie z zaplanowanymi kątami wiązek terapeutycznych. Takie rozwiązanie daje większą pewność, że rozkład dawki jaki otrzyma pacjent będzie zgodny z tym zaplanowanym dla pacjenta wirtualnie. Jedynym ograniczeniem metody jest czas związany zarówno z przygotowaniem fantomu w systemie planowania leczenia oraz czasem wydruku.

\section{Sesja plakatowa: Diagnostyka Obrazowa [SP-DO]}

\section{SP-DO-053: Poszukiwanie znacznika do obrazowania rozwoju raka jasnokomórkowego nerki w modelu mysim}

Łukasz Cheda ${ }^{1}$, Zbigniew Rogulski², Krzysztof Kilian³, Damian Strzemecki ${ }^{1,4}$, Michał Fiedorowicz ${ }^{4}$, Marlena Kamińska ${ }^{4}$, Mohammed Imran Khan ${ }^{5}$, Anna Czarnecka ${ }^{5}$, Paweł Grieb ${ }^{4}$, Cezary Szczylik ${ }^{5}$

(1) Centrum Nauk Biologiczno-Chemicznych UW, Warszawa, Polska

(2) Wydziat Chemii UW, Warszawa, Polska

(3) Środowiskowe Laboratorium Ciężkich Jonów UW, Warszawa, Polska

(4) Instytut Medycyny Doświadczalnej i Klinicznej im. M. Mossakowskiego PAN, Warszawa, Polska

(5) Wojskowy Instytut Medyczny, Warszawa, Polska

WPROWADZENIE: Celem pracy było dobranie znacznika pozwalającego na zobrazowanie rozwoju raka jasnokomórkowego nerki z wykorzystaniem metody pozytonowej tomografii emisyjnej (PET) w modelu mysim.

MATERIAŁ I METODA: Subpopulacje komórek ludzkiego raka jasnokomórkowego zostały wszczepione podskórnie do myszy szczepu SCID. Po 3 tygodniach od implementacji komórek obiekty poddano badaniu PET/CT z wykorzystaniem znaczników: 18FDG, 18FCH, 18FMISO. Otrzymane wyniki analizowano dwiema metodami: obliczono SUV tkanki nowotworowej oraz porównując średnią intensywność sygnału guza do organu odniesienia.

WYNIKI: Otrzymane wyniki pozwoliły wykluczyć dalsze wykorzystanie 18FCH oraz potwierdziły celowość wykorzystania 18FDG do oceny aktywności metabolicznej i 18FMISO do oceny stanów niedotlenienia w badaniach tego modelu. Zaobserwowano również różnice w aktywności metabolicznej oraz stanach niedotlenienia między poszczególnymi subpopulacjami komórkowymi.

WNIOSKI: Z doniesień literaturowych można wnioskować o niepodatności na obrazowanie technikami izotopowymi jasnokomórkowego raka nerki, jednak uzyskane wyniki pokazują możliwość zastosowania klasycznych znaczników do oceny parametrów guza.

[Praca powstałą w ramach projektu „Identyfikacja nowych markerów komórek macierzystych raka 
jasnokomórkowego nerki - badania w modelu mysim przy użyciu technik obrazowania” finansowanego ze środków NCN, nr umowy 2014/13/B/NZ1/04010].

\section{SP-DO-054: Obrazowanie stanu niedotlenienia tkanki nowotworowej w modelu zwierzęcym} z wykorzystaniem 18Fluoromizonidazolu (18FMISO)

Łukasz Cheda ${ }^{\mathbf{1}}$, Zbigniew Rogulski ${ }^{2}$, Krzysztof Kilian ${ }^{3}$, Damian Strzemecki ${ }^{1,4}$, Łukasz Kiraga ${ }^{5}$, Magdalena $\mathrm{Król}^{5}$

(1) Centrum Nauk Biologiczno-Chemicznych UW, Warszawa, Polska

(2) Wydziat Chemii UW, Warszawa, Polska

(3) Środowiskowe Laboratorium Ciężkich Jonów UW, Warszawa, Polska

(4) Instytut Medycyny Doświadczalnej i Klinicznej im. M. Mossakowskiego PAN, Warszawa, Polska

(5) Wydziat Medycyny Weterynaryjnej SGGW, Warszawa, Polska

WPROWADZENIE: Celem pracy było zbadanie rozwoju patologicznego stanu hipoksji wraz ze wzrostem nowotworu. Niedotlenienie często związane jest z niekontrolowanymi procesami rozrostu i powoduje upośledzeniem mechanizmów transportowych m. in. tlenu. Komórki w stanie hipoksji charakteryzują się wyższą opornością na większość strategii terapeutycznych oraz wyższe prawdopodobieństwo zmian odległych i nawrotów.

MATERIAŁ I METODA: W badaniach wykorzystano model mysiego nowotworu jelita grubego wszepionego podskórnie myszom szczepu balb/c. W różnych punktach czasowych po implementacji komórek obiekty poddano badaniu PET/CT z wykorzystaniem 18Fluoromizonidazolu (18FMISO). Otrzymane wyniki analizowano dwiema metodami: obliczono SUV tkanki nowotworowej oraz porównując średnią intensywność sygnału guza do organu odniesienia.

WYNIKI: Otrzymane wyniki pozwoliły na zaobserwowanie rozwój obszaru hipoksji przez pierwsze 2 tygodnie wzrostu guza, następnie intensywność sygnału w tkance nowotworowej ulega redukcji.

WNIOSKI: Uzyskane wyniki potwierdzają wzrost poziomu niedotlenienia, co jest związane z niedostateczną szybkością angiogenezy w rozwijającej tkance nowotworowej. Zanik sygnału w dalszych punktach czasowych wynika z obumierania wnętrza guza pozbawionego dostępu do substancji odżywczych. Znajomość stanu hipoksji wewnątrz guza pozwoli na dobranie opartego na komórce nośnika leków przeciwnowotworowych. [Praca powstałą w ramach projektu SONATA BIS finansowanego ze środków NCN, nr umowy UMO2015/18/E/NZ6/00642].

SP-DO-055: Optymalizacja parametrów w metodzie Seed Corelation Analysis (SCA) w obszarze kory słuchowej

Ilona Karpiel ${ }^{1,2,3}$, Uwe Klose ${ }^{3}$, Zofia Drzazga ${ }^{1,2}$, Edyta Charyasz-Lex ${ }^{3}$

(1) Instytut Fizyki im. A. Chełkowskiego, Zakład Fizyki Medycznej, Uniwersytet Śląski, Katowice, Polska

(2) Śląskie Międzyuczelniane Centrum Edukacji i Badan Interdyscyplinarnych, Chorzów, Polska

(3) Zakład Diagnostyki i Neuroradiologii, Szpital Uniwersytecki w Tuebingen, Niemcy

WPROWADZENIE: Celem pracy jest zastosowanie metody Seed Corelation Analysis (SCA) w analizie Resting-state Functional MRI (rsFMRI) dla kory słuchowej oraz optymalizacja parametrów w DPARSF toolbox ( ang. Data Processing Assistant for Resting-State fMRI).

MATERIAŁ I METODA: Badania rsfMRI przeprowadzono w zakładzie Diagnostyki i Neuroradiologii w szpitalu w Tuebingen w Niemczech. W badaniu uczestniczyło 20 pacjentów (13 kobiet i 7 mężczyzn). Wszystkie badania zostały wykonane przy użyciu skanera Siemens Magnetom 3T, 20 - kanałowej cewki i dodatkowego wyposażenia. Do analizy wykorzystano DPARSF toolbox, w którym przeprowadzono optymalizację następujących parametrów : amplituda fluktuacji niskiej częstotliwości - ALLF (ang. amplitude of low-frequency fluctuaction), maski Gussowskiej-kernel (Gaussian kernel) oraz sferycznego obszaru zainteresowania - ROI ( spherical ROI). Program ten był również użyty do zaimplementowania 24 obszarów zainteresowania (ROIs) a przedstawienie wyników umożliwiły specjalnie utworzone 2 skrypty 
W MATLABIE.

WYNIKI: Obliczenia wykonano dla 259 przypadków. Bazując na macierzy połączeń (connectivity matrix) znaleziono maksymalne wartości korelacji 2 dowolnie wybranych ROI. Przykładowo dla pary (ROIs) z obszarów Brodmanna BA 41 L i BA 42L dla kernela 5 przy użyciu ALFF 0.01-0.08, promienia sfery obszaru zainteresowania równej 8 otrzymano najwyższe wartości korelacji (o.9). Natomiast dla kernela 8, wartość korelacji wzrosła do wartość 1,004. Zaobserwowano, że zmiana jednego parametru w analizie DPASRF powoduje wyraźne zmiany w wartościach korelacji.

WNIOSKI: Badania wykazały, że najwyższe wartości korelacji w obszarze kory słuchowej uzyskano dla sferycznych obszarów zainteresowania (ROIs) o promieniu 8, przy czym dla wartości $\mathrm{r}=3 \mathrm{i} \mathrm{r}=4$ zaobserwowano te same wartości. Wyższe wartości korelacji dla pary ROI uzyskano dla ALLF w zakresie 0.01-0.04 niż dla 0.01-0.08 najczęściej stosowanych. Ponadto użycie kernelu równego 8 okazało się najkorzystniejsze w przeprowadzonej analizie.

\section{SP-DO-056: Termowizja w ocenie wydolności sportowców}

Teresa Kasprzyk ${ }^{1}$, Agata Stanek ${ }^{2}$, Karolina Sieroń-Stołtny ${ }^{3}$, Armand Cholewka ${ }^{1}$

(1) Instytut Fizyki im. A. Chełkowskiego, Zakład Fizyki Medycznej, Uniwersytet Śląski, Katowice, Polska

(2) Katedra i Oddział Kliniczny Chorób Wewnętrznych, Angiologii i Medycyny Fizykalnej, Ślq̨ski Uniwersytet Medyczny w Katowicach, Katowice, Polska

(3) Wydział Nauk o Zdrowiu w Katowicach, Ślaski Uniwersytet Medyczny w Katowicach, Zakład Medycyny Fizykalnej Katedry Fizjoterapii, Katowice, Polska

WPROWADZENIE: Obrazowanie termiczne jest nieinwazyjną metodą pomiaru temperatury powierzchni ciała umożliwiającą jednocześnie przedstawienie rozkładu w formie mapy termicznej badanej powierzchni. Celem pracy była odpowiedź na pytanie, czy na podstawie zarówno zmian temperatury powierzchni ciała oraz temperatury wewnętrznej sportowca możemy określić parametry użyteczne w ocenie stopnia wydolności sportowca oraz w planowaniu cyklu treningowego.

MATERIAŁ I METODA: W pomiarach udział wzięło 12 kolarzy płci męskiej na średnim poziomie zaawansowania. Pomiary przeprowadzono $\mathrm{w}$ trakcie standardowych progresywnych testów wydolności kolarzy wykonując termogramy wybranych obszarów zainteresowania (mających największy wkład do średniej temperatury całej powierzchni ciała człowieka) co 3 minuty. Oprócz pomiarów temperatury powierzchni oraz wewnętrznej uzyskano również parametry oddechowe, poziom kwasu mlekowego we krwi oraz tętno zawodnika. Ponadto ergometr umożliwiaj pomiar mocy ochotnika.

WYNIKI: Otrzymane parametry termiczne wykorzystano do obliczenia średniej temperatury powierzchni ciała oraz strumienia energii radiacyjnej promieniowania cieplnego na podstawie prawa Stefana-Boltzmanna. Analiza otrzymanych wyników wskazuje na oscylacje temperatury powierzchni ciała w trakcie wysiłku progresywnego. Co ciekawe wartość temperatury wewnętrznej nie wykazuje liniowego wzrostu natomiast ma przebieg sigmoidalny. Korelacje uzyskane pomiędzy obciążeniem na ergometrze oraz temperaturą powierzchni ciała cechują się wysokim współczynnikiem korelacji Pearsona.

WNIOSKI: Wydaje się, iż obrazowanie termiczne może znaleźć zastosowanie w sporcie jako metoda pomocnicza w monitorowaniu rozwoju wydolności sportowca.

SP-DO-057: Metody oceny monitorów stosowane do prezentacji obrazów medycznych w DCO we Wrocławiu

Honorata Ziemiańska1, Maciej Raczkowski ${ }^{1}$, Marzena Janiszewska ${ }^{1}$, Małgorzata Drobiazgiewicz ${ }^{1}$

(1) Zakład Fizyki Medycznej, Dolnośląskie Centrum Onkologii, Wrocław, Polska

WPROWADZENIE: Celem pracy jest przedstawienie procedur kontroli monitorów stosowanych do prezentacji obrazów medycznych w świetle polskich wymagań prawnych.

MATERIAŁ I METODA: Kontroli zostało poddanych łącznie 39 monitorów, stosowannych do opisu badań tomografii komputerowej, mamografii, rentgenodiagnostyki, rezonansu oraz badań PET CT. Pomiarami 
objęto także monitory do fluoroskopii oraz monitory do planowania leczenia. Przemierzono monitory EIZO, NEC, BARCO.

W zakresie badań wykonano testy podstawowe i specjalistyczne zgodnie z Rozporządzeniem Ministra Zdrowia z dnia 12 listopada 2015 r.zmieniające rozporządzenie w sprawie warunków bezpiecznego stosowania promieniowania jonizującego dla wszystkich rodzajów ekspozycji medycznej.

Testy podstawowe wykonywane przez lakarzy radiologów w dniu kidy na monitorze opisywane są badania, wg wytycznych zawartych w zał. nr 6 do Rozporządzeniem Ministra Zdrowia.

Testy specjalistyczne wykonywane przez fizyków nie żadziej niż raz do roku oraz po każdej istotnej ingerencji serwisu, wg wytycznych zawartych w zał. nr 6 do Rozporządzeniem Ministra Zdrowia, z uwzględnieniem wymagań za

WYNIKI: Wyniki przedstawione zostały w postaci wewnętrznych protokołów badania poprawności monitorów.

Na 39 badanych monitorów stwierdzona następujące, najczęściej powtarzeające się odstępstwa: brak odwzorowania krzywej DICOM bądź odstępstwa od niej, zbyt niska luminancja dla monitorów opisowych tomograficznych.W przypadku przekroczenia progów reagowania wzywano serwis celem kalibracji/regulacji. WNIOSKI: Rozporządzeniem Ministra Zdrowia z dnia 12 listopada 2015 r.zmieniające rozporządzenie w sprawie warunków bezpiecznego stosowania promieniowania jonizującego dla wszystkich rodzajów ekspozycji medycznej nakłada na uzytkowniak obowiązek wykonywania testów podstawowych i specjalistycznych. Ocena monitorów dokonywana w zakresie testów podstawowych i specjalistycznych ma zagwarantować uzytkownikoi optymalne, niezmienne w określonym zakresie, warunki pracy co ma bezpośrednie przełożenie na poprawność diagnozy i rzetelność podejmowanych decyzji medycznych.

\section{SP-DO-058: Optymalizacja protokołu IVIM-DWI (Intra-Voxel Incoherent Motion Diffusion- Weighted Imaging) w badaniu MR wątroby}

Katarzyna Pasicz ${ }^{1}$, Joanna Podgórska², Ewa Fabiszewska ${ }^{1}$, Jakub Jasieniak ${ }^{2}$, Witold Skrzyński ${ }^{1}$, Agnieszka Anysz-Grodzicka ${ }^{2}$, Jakub Pałucki ${ }^{2}$, Iwona Grabska ${ }^{1}$, Andrzej Cieszanowski², Paweł Kukołowicz ${ }^{1}$

(1) Zakład Fizyki Medycznej Centrum Onkologii - Instytut im. M.Skłodowskiej-Curie w Warszawie, Polska

(2) Zakład Radiologii Centrum Onkologii - Instytut im. M.Skłodowskiej-Curie w Warszawie, Polska

WPROWADZENIE: Celem pracy był wybór optymalnego, pod względem czasu akwizycji i powtarzalności wyników, protokołu IVIM-DWI badania MR wątroby.

MATERIAŁ I METODA: U dwudziestu zdrowych ochotników (10 mężczyzn, 10 kobiet; wiek: 25-62 lat; średnio: 39) wykonano badanie MR przy użyciu aparatu 3.oT (Siemens, Magnetom Skyra) z użyciem cewki 18-kanałowej i sekwencji EPI (echo-planar imaging) DWI i następujących wartość b=0, 10, 30, 50, 75, 100, 150, 200, 500, $900 \mathrm{~s} / \mathrm{mm}^{\wedge} 2$. U każdego z ochotników wykonano cztery sekwencje: podczas swobodnego oddychania ( $\mathrm{z}$ NSA=1 i NSA=3), z bramkowaniem oddechowym (z NSA=1 i NSA=3). Czas trwania poszczególnych sekwencji wynosił od 1 min. 58 sek. do 16 min. 5 sek. Do wyznaczenia parametrów IVIM: f, D i D* posłużyły średnie wartości pikseli z obszarów zainteresowania zaznaczanych przez lekarza radiologa. Zaznaczano po dwa obszary zainteresowania - oddzielnie dla prawego i lewego płata wątroby w obszarach wykazujących jednorodny sygnał (bez widocznych naczyń i artefaktów). Parametry IVIM wyznaczono przy użyciu modelu Le Bihana i wsp. Do analizy użyto programu Gnuplot wersja 5.o, patchlevel 4.

WYNIKI: Dla prawego płata wątroby dla sekwencji NSA=3 przy bramkowaniu oddechowym otrzymano następujące wartości parametrów IVIM (średnia \pm odchylenie standardowe): $\mathrm{f}=0,21 \pm 0,07, \mathrm{D}=1,08 \pm 0,12 \mathrm{x}$ $10^{\wedge}-3 \mathrm{~mm}^{\wedge} 2 / \mathrm{s}, \mathrm{D}^{*}=81 \pm 43 \times 10^{\wedge}-3 \mathrm{~mm}^{\wedge} 2 / \mathrm{s}$, a dla lewego płata wątroby $\mathrm{f}=0,28 \pm 0,14, \mathrm{D}=1,15 \pm 0,41 \times 10^{\wedge}-$ $3 \mathrm{~mm}^{\wedge} 2 / \mathrm{s}, \mathrm{D}^{*}=89 \pm 55 \times 10^{\wedge}-3 \mathrm{~mm}^{\wedge} 2 / \mathrm{s}$. Natomiast dla sekwencji $\mathrm{NSA}=1$ dla prawego płata otrzymano odpowiednio: $\mathrm{f}=0,28 \pm 0,14, \mathrm{D}=0,98 \pm 0,41 \times 10^{\wedge}-3 \mathrm{~mm}^{\wedge} 2 / \mathrm{s}, \mathrm{D}^{*}=70 \pm 45 \times 10^{\wedge}-3 \mathrm{~mm}^{\wedge} 2 / \mathrm{s}$, a dla lewego płata wątroby $\mathrm{f}=0,44 \pm 0,30, \mathrm{D}=1,01 \pm 0,47 \times 10^{\wedge}-3 \mathrm{~mm}^{\wedge} 2 / \mathrm{s}, \mathrm{D}^{*}=51 \pm 56 \times 10^{\wedge}-3 \mathrm{~mm}^{\wedge} 2 / \mathrm{s}$.

Dla prawego i lewego płata wątroby średnie wartości f, D i $\mathrm{D}^{*}$ dla sekwencji NSA=3 wykonanej przy swobodnym oddechu nie różniły się istotnie statystycznie $(\mathrm{p}=0,05)$ od wartości otrzymanych w sekwencji bramkowanej oddechowo.

Czas trwania akwizycji przy swobodnym oddechu dla NSA=3 wynosił 4 minuty, natomiast przy bramkowaniu 
oddechowym zmieniał się w zależności od sposobu oddychania pacjenta i wynosił od 7 min. 45 sek. do 16 min. 5 sek.

WNIOSKI: Sekwencja NSA=3 podczas swobodnego oddychania jest optymalna do badania MR wątroby techniką IVIM-DWI, zarówno pod względem powtarzalności wyników, jak i czasu akwizycji. Ocena przydatności tej sekwencji u pacjentów badanych techniką IVIM-DWI wymaga potwierdzenia w dalszych pracach.

\section{PLAKATY ELEKTRONICZNE}

\section{Plakat elektroniczny: Nanotechnologia [EP-NT]}

EP-NT-059: Innowacyjne nośniki w terapii genowej - układy na bazie surfaktantów trigemini i lipidów

Żaneta Kołodziejska ${ }^{1}$, Zuzanna Pietralik ${ }^{1}$, Daria Grobys², Maciej Kozak ${ }^{1,3}$

(1) Zakład Fizyki Makromolekularnej, Wydział Fizyki, Uniwersytet im. Adama Mickiewicza, Poznań, Polska

(2) Zakład Bioenergetyki, Wydziat Biologii, Uniwersytet im. Adama Mickiewicza, Poznań, Polska

(3) Środowiskowe Laboratorium Badań SAXS, Wydział Fizyki, Uniwersytet im. Adama Mickiewicza, Poznań, Polska

WPROWADZENIE: Celem niniejszej pracy była charakterystyka kompleksów otrzymanych na bazie wybranych kationowych surfaktantów trimerycznych oraz formulacji lipidowych na bazie pochodnych fosfatydylocholiny i fosfatydyloetanolaminy (DMPC, DPPC, DOPE) z DNA o różnej długości (21 bp, 185 bp, $20 \mathrm{kbp}$ ) oraz określenie ich przydatności jako nośników w terapii genowej.

Terapia genowa jest działem nowoczesnej medycy, którego celem jest leczenie chorób, eliminującich przyczynę. Metoda ta polega na dostarczeniu do organizmy właściwej kopii genu, który ma zapewnić prawidłowe funkcjonowanie komórek organizmu. Warunkiem efektywnej transfekcji jest stworzenie biozgodnych, nietoksycznych i łatwych w produkcji nośników, które ochronią materiał genetyczny oraz dostarczą go do docelowych komórek.

Obecnie duże nadzieje pokłada się w niewirusowych wektorach opartych na surfaktantach i naturalnych lipidach - lipopleksach.

MATERIAŁ I METODA: Wydajność wiązania DNA i toksyczność badanych układów przeanalizowano na podstawie elektroforezy żelowej oraz testów MTT na linii komórkowej HeLa. Charakterystyka strukturalna została oparta na analizie wyników uzyskanych metodami małokątowego rozpraszania promieniowania rentgenowskiego SAXS oraz mikroskopii sił atomowych AFM.

WYNIKI: Otrzymane wyniki testów elektroforetycznych wskazują, że surfaktanty trigemini cechuje wysoka efektywność kompleksowania. Wydajność procesu większa również obecność lipidów w układzie, dodatkowo lipidy znacząco zmniejszają efekty cytotoksyczne. układy surfaktant/lipid/DNA mogą przyjąć strukturę lamelarną oraz struktury o wyższej symetrii (regularna, heksagonalna).

WNIOSKI: Układynabaziesurfaktantówtrigeminiilipidów cechująsięniskątoksycznościąipowtarzalnością preparatyki, dlatego mogą posłużyć do stworzenia efektywnych, biozgodnych i innowacyjnych nośników dla terapii genowej.

EP-NT-060: Wpływ promieniowania UV na generowanie wolnych rodników w układach nanocząstki-krew.

Kamila Urbaniak ${ }^{1}$, Bernadeta Dobosz ${ }^{1}$, Ryszard Krzyminiewski ${ }^{1}$, Grzegorz Schroeder ${ }^{2}$, Joanna Kruczewska ${ }^{2}$

(1) Zakład Fizyki Medycznej, Wydziat Fizyki UAM Poznań, Polska

(2) Zakład Chemii Supramolekularnej, Wydział Chemii UAM Poznań, Polska

WPROWADZENIE: Celem pracy było zbadanie wpływu promieniowania UV na powstawanie wolnych 
rodników w próbkach nanocząstek, krwi oraz surowicy.

MATERIAŁ I METODA: Badania przeprowadzone zostały przy pomocy elektronowego rezonansu spinowego. Wykorzystanym materiałem badawczym były nanocząstki magnetytu $\mathrm{Fe}_{3} \mathrm{O} 4$ bez stabilizatorów oraz stabilizowane kwasem oleinowym. Próbki krwi pochodziły zarówno od pacjentów bez nowotworów, jak i pacjentów chorujących na nowotwór. Badana surowica była pochodzenia zwierzęcego. Zbadane zostały próbki nanocząstek, krwi oraz surowicy w roztworach wodnych, a następnie nanocząstki z krwią lub surowicą. Źródłem promieniowania UV była lampa UV firmy Emita VP6o, 18oW. Wszystkie pomiary wykonane zostały w temperaturze ciekłego azotu.

WYNIKI: W roztworach wodnych nanocząstek, niezależnie od tego czy były stabilizowane czy nie, nie zaobserwowano sygnałów od wolnych rodników. Sygnał ten pojawił się tylko w próbkach nanocząstek bez stabilizatora gdy dodano do nich krew lub surowicę.

WNIOSKI: Na podstawie otrzymanych wyników stwierdzono, że obecność krwi lub surowicy ułatwia generowanie wolnych rodników w układach nanocząstki-krew lub nanocząstki-surowica. Znaczenie ma również obecność stabilizatora, który utrudnia powstawanie wolnych rodników.

EP-NT-061: Badania SAXS oraz dynamika konformacyjna amyloidogennej, nie ustrukturyzowanej N-terminalnej domeny ludzkiego białka prionowego

Maciej Gielnik ${ }^{1}$, Igor Zhukov ${ }^{2,3}$, Wojciech Kwiatek ${ }^{4}$, Maciej Kozak ${ }^{1,5}$

(1) Zakład Fizyki Makromolekularnej, Wydział Fizyki, Uniwersytet im. Adama Mickiewicza, Poznań, Polska

(2) Centrum NanoBiomedyczne, Uniwersytet im. Adama Mickiewicza, Poznań, Polska

(3) Instytut Biochemii i Biofizyki PAN, Warszawa, Polska

(4) Instytut Fizyki Jądrowej im. Henryka Niewodniczańskiego PAN, Kraków, Polska

(5) Środowiskowe Laboratorium Badań SAXS, Wydział Fizyki, Uniwersytet im. Adama Mickiewicza, Poznań, Polska

WPROWADZENIE: Ludzkie białko prionowe (PrPC) jest niewielkim glikozylowanym białkiem (231 aminikwasów)j. Cząsteczka PrPC uformowana jest w postaci dwóch domen: nieustrukturyzowanej N-terminalnej oraz C-terminalnej ustrukturyzowanej (głównie a-helikalnej) i zakotwiczonej w bBonie poprzez glikolipid. WedBug obecnego stanu wiedzy, biaBko to mo|e podlega przej[ciu konformacyjnemu ze stanu natywnego (PrPC) do patologicznego (PrPSc). Ta ostatnia forma strukturalna ró|ni si od formy PrPC zawarto[ci dominujcej struktury drugorzdowej (typu beta) i łączona jest z powstawaniem śmiertelnych chorób zwanych pasażowalnymi encefalopatiami gąbczastymi (ang. Transmissible spongiform encephalopathies, TSE). Jako molekularne przyczyny wszystkich chorób z rodziny TSE uważa się wzrost dynamiki konformacyjnej wewnątrz globularnej domeny PrPC, powodujące konwersję PrPC $\rightarrow$ PrPSc. Niedawno opublikowane wyniki dostarczają nowego spojrzenia na możliwe przyczyny TSE. Według badaczy (Surewicz 2016) N-terminalna nieustrukturyzowana domena PrPC może spontanicznie tworzyć fibryle amyloidowe, będące w 100\% zakaźne i toksyczne dla modeli zwierzęcych. Celem niniejszejpracy było zbadanie dynamiki konformacyjnej peptydu (huPrP58-91) zaprojektowanego na bazie N-terminalnej domeny ludzkiego białka prionowego PrPC.

MATERIAŁ I METODA: Do badań struktury peptydu zastosowaliśmy metodę małokątowego rozpraszania promieniowania rentgenowskiego (SAXS), spektroskopii dichroizmu kołowego (CD), mikroskopii sił atomowych (AFM) i symulacji dynamiki molekularnej (MD).

WYNIKI: Uzyskane wyniki świadczą o nietypowej konformacji peptydu, różniącej się od kłębka statystycznego. Promień żyracji peptydu prionowego, w przypadku całkowitego nieustrukturyzowania powinien wynieść $1.65 \mathrm{~nm}$. Stosując przybliżenie Guiniera dla krzywej SAXS i dynamikę molekularną uzyskano promienie żyracji wynoszące odpowiednio $\mathrm{Rg}=1.23 \mathrm{~nm}$ i $\mathrm{Rg}=1.176 \mathrm{~nm}$. Na podstawie wykresu Kratkiego można wnioskować, iż peptyd prionowy przybiera zarówno konformację globularną, jak i rozciągniętego łańcucha. Potwierdzają to modele komputerowe, dla których obliczone widmo CD zgadza się z danymi eksperymentalnymi. Kompaktowy w porównaniu do białek nieustrukturyzowanych wydaje się być również maksymalny rozmiar cząsteczki Dmax = $4.5 \mathrm{~nm}$, zmierzony niezależnie na AFM, SAXS i MD. Co więcej wyniki MD sugerują samoistne tworzenie się arkuszy beta i beta zakrętów w obrębie peptydu.

WNIOSKI: Na podstawie uzyskanych wyników wysnuwamy przypuszczenie, iż być może N-terminalna 
domena zawierająca obszar oktapowtórzeń (octarepeats) białka PrP jest kluczowym fragmentem białka PrP, odpowiedzialnym prawdopodobnie za zmianę konformacyjną PrPC $\rightarrow$ PrPSc.

[Zaprezentowane badania wykonano w ramach projektu o numerze 2014/15/B/ST4/O4839, finansowanego przez Narodowe Centrum Nauki].

\section{EP-NT-062: Pomiary impedancyjne zdrowej skóry ludzkiej poddane działaniu kolagenu egzogennego \\ Marlena Gauza-Włodarczyk ${ }^{1}$, Agata Malik ${ }^{1}$, Leszek Kubisz ${ }^{1}$, Dorota Hojan-Jezierska² \\ (1) Zakład Biofizyki Katedry Biofizyki, Uniwersytet Medyczny im. Karola Marcinkowskiego w Poznaniu, Polska \\ (2) Zakład Protetyki Stuchu Katedry Biofizyki, Uniwersytet Medyczny im. Karola Marcinkowskiego w Poznaniu, Polska}

WPROWADZENIE: Kolagen jest jednym z podstawowych białek organizmów ludzkich i zwierzęcych. Jest on między innymi głównym składnikiem skóry, który w istotny sposób determinuje jej wytrzymałość mechaniczną (w skórze właściwej kolagen stanowi aż 70\%). Jego zawartość wpływa ponadto, na poprawę jakości skóry, na proces starzenia się czy na zniwelowanie defektów naskórnych.

MATERIAŁ I METODA: Przeprowadzone badania stanowiły próbę wykazania, że efektywność zabiegów poprawiających kondycję skóry zależy nie tylko od rodzaju oraz budowy elementarnej zastosowanego preparatu kolagenowego, ale przede wszystkim od sposobu jego aplikacji.

WYNIKI: Badania przeprowadzono w dwóch 13 osobowych podgrupach zróżnicowanych pod względem sposobu aplikacji kolagenu. W pierwszej kolagen aplikowany był przezskórnie jedynie przez wcieranie w drugiej natomiast, przez wcieranie z jednoczesną aplikacją pola ultradźwiękowego (80o kHz; 1,o W/cm2). WNIOSKI: We wszystkich przypadkach zastosowano kolagen pochodzący ze skór rybich (tołpygi) w postaci żelu. Efektywność zabiegu określana była na podstawie pomiarów zmian w wybranych parametrach elektrycznych skóry.

Pomiary parametrów elektrycznych skóry wykazały istotne zmiany.

Zastosowanie wyłącznie kolagenu rybiego wpłynęło na wzrost oporu elektrycznego i spadek pojemności elektrycznej, natomiast jednoczesne zastosowanie ultradźwięków spowodowało odwrotną tendencję, powodując spadek oporu elektrycznego i wzrost pojemności elektrycznej.

\section{EP-NT-063: Fulereny C6o jako środki kontrastujące - analiza strukturalna spektroskopowa i toksykologiczna \\ Augustyn Moliński ${ }^{1}, \dot{Z}_{\text {aneta Kołodziejska }}{ }^{1}$ Zuzanna Pietralik ${ }^{1}$, Justyna Iżykowska1, Maciej Kozak ${ }^{1,2}$ \\ (1) Zakład Fizyki Makromolekularnej, Wydział Fizyki, Uniwersytet im. Adama Mickiewicza w Poznaniu, Poznań, Polska \\ (2) Środowiskowe Laboratorium Badań SAXS, Wydział Fizyki, Uniwersytet im. Adama Mickiewicza w Poznaniu, Poznań, Polska}

WPROWADZENIE: Nanomateriały węglowe (nanorurki, grafen czy fulereny), dzięki swoim unikalnym właściwościom, zainspirowały wiele projektów badawczych w różnych dziedzinach fizyki, począwszy od nanotechnologii do nanomedycyny. Szczególnie fulereny przedstawiają wartość dla nowoczesnej technologii medycznej, ze względu na szerokie możliwości ich zastosowania. Jedną z tych możliwości jest wykorzystanie metalofulerenów, czyli cząsteczek fulerenów z zamkniętym wewnątrz jonem metalu, jako środka kontrastującego w obrazowaniu medycznym metodą rezonansu magnetycznego [1].

Problemem, jaki często ujawnia się w próbach zaaplikowania fulerenów w celach medycznych,jest potencjalnie silna toksyczność nanomateriałów węglowych dla żywych komórek [2]. Celem przedstawionych badań było stworzenie, bazujących na zdyspergowanych fulerenach, roztworów o możliwie niskiej toksyczności, które w kolejnym etapie badań mogłyby zostać rozwinięte do środków kontrastujących, bazujących także na metalofulerenach, które następnie znaleźć by mogły zastosowanie zarówno w badaniach obrazowych in vitro jak $\mathrm{i}$ in vivo.

MATERIAŁ I METODA: Aby osiągnąć opisany cel wykorzystane zostały fulereny C6o, pluronik F127 w charakterze środka dyspergującego, oraz lipid DMPC, który zwiększa biokompatybilność, wspomaga absorbcję komórkową oraz dodatkowo służył jako model dwuwarstwy błony komórkowej. 
WYNIKI: W niniejszej pracy zaprezentowane zostaną wyniki badań toksyczności przeprowadzone metodą MTT na komórkach HeLa, badania strukturalne wykonane techniką mikroskopii AFM oraz wyniki badań spektroskopowych przeprowadzonych metodami FTIR oraz SAXS.

WNIOSKI: Wyniki wykonanych badań pozytywnie rokują dalszemu rozwojowi badanego związku.

[1] M. Mikawa i in., „Paramagnetic Water-Soluble Metallofullerenes Having the Highest Relaxivity for MRI Contrast Agents", Bioconjug. Chem., t. 12, nr 4, ss. 510-514, lip. 2001.

[2] A. Magrez i in., „Cellular Toxicity of Carbon-Based Nanomaterials”, Nano Lett., t. 6, nr 6, ss. 1121-1125, cze. 2006.

\section{EP-NT-064: Proces oligomeryzacji i jego znaczenie w chorobach neurodegeneracyjnych na} przykładzie ludzkiej cystatyny $C$

Zuzanna Pietralik , Aneta Szymańska², Janet R. Kumita ${ }^{3}$, Christopher M. Dobson³, Maciej Kozak ${ }^{1,4}$

(1) Zakład Fizyki Makromolekularnej, Wydział Fizyki, Uniwersytet im. Adama Mickiewicza w Poznaniu, Poznań, Polska

(2) Wydziat Chemii, Uniwersytet Gdański, Gdańsk, Polska

(3) Department of Chemistry, University of Cambridge, Cambridge, United Kingdom

(4) Środowiskowe Laboratorium Badań SAXS, Wydział Fizyki, Uniwersytet im. Adama Mickiewicza w Poznaniu, Poznań, Polska

WPROWADZENIE: Pomimo zróżnicowanych przyczyn występowania, przebiegu czy objawów; choroby neurodegeneracyjne takie jak choroba Alzheimera, Parkinsona czy Huntingtona wydają się mieć wspólny mianownik którym jest tworzenie i odkładanie się agregatów białek, w postaci wysoce uporządkowanych depozytów [1]. Właśnie dlatego badanie procesu oligomeryzacji białek jest niezwykle istotne gdyż w jego trakcie, monomeryczne, w pełni funkcjonalne białko ulega transformacji do nierozpuszczalnych, złogów amyloidowych.

W naszych badaniach zajęliśmy się ludzką cystatyną C (ang. human cystatin C, HCC) które jest małym białkiem złożonym z 120 aminokwasów (13 kDa) i powszechnie występuje we wszystkich płynach ustrojowych, ze szczególnie wysokim stężeniem w płynie mózgowo-rdzeniowym. Jego funkcją jest inhibicja proteaz cysteinowych. Białko to posiada zdolność do formownia agregatów poprzez mechanizm wymiany domenowej (ang. domain swapping) [2].

MATERIAŁ I METODA: Przeprowadzone badania obejmowały otrzymanie oligomerów ludzkiej cystatyny $\mathrm{C}$ typu dzikiego a także pięciu mutantów punktowych, w pozycji 57 (pozycja określona jako źródło niestabilności konformacyjnej prowadzące do tworzenia dimerów) oraz w pozycji 68 (miejsce naturalnie występującej mutacji, związanej z dziedziczną angiopatią amyloidową typu Islandzkiego) [3].

WYNIKI: Przetestowano różnorodne warunki otrzymywania oligomerów oraz fibryli, a ich skuteczność określono na podstawie elektroforezy żelowej oraz badań fluorescencyjnych z tioflawiną T. Otrzymane agregaty zostały scharakteryzowane za pomocą mikroskopii sił atomowych AFM oraz transmisyjnej mikroskopii elektronowej TEM.

WNIOSKI: Opracowanie optymalnych warunków oligomeryzacji pozwoliło otrzymać agregaty oraz fibryle dla wszystkich badanych białek.

[Projekt został sfinansowany ze środków Narodowego Centrum Nauki przyznanych na podstawie decyzji numer DEC-2012/06/M/ST4/oo036].

[1] F. Chiti, C.M. Dobson, Annu. Rev. Biochem. 75 (2006) 333.

[2] R. Janowski, M. Abrahamson, A. Grubb, M. Jaskolski, J. Mol. Biol. 341 (2004) 151.

[3] M. Orlikowska, E. Jankowska, R. Kołodziejczyk, M. Jaskólski, A. Szymańska, J. Struct. Biol. 173 (2011) 406.

EP-NT-065: Wpływ struktury surfaktantu na poziom dyspersji i toksyczność nanorurek węglowych w kontekście ich potencjalnych zastosowań nanomedycznych

Jakub Zaręba ${ }^{1}$, Justyna Iżykowska ${ }^{1}$, Michalina Skupinn ${ }^{1,2}$, Augustyn Moliński ${ }^{1}$, Stefan Jurga ${ }^{1,2}$, Maciej Kozak $^{1}$

(1) Zakład Fizyki Makromolekularnej, Wydziat Fizyki,Uniwersytet Adama Mickiewicza w Poznaniu, Poznań, Polska 
(2) Centrum NanoBioMedyczne, Uniwersytet Adama Mickiewicza w Poznaniu, Poznań, Polska

WPROWADZENIE: Celem prowadzonych badań było określenie możliwości stabilizacji zawiesin nanorurek węglowych w wodzie (NW) przy użyciu surfaktantów kationowych. Nanorurki węglowe są nanostrukturami uformowanymi ze zwiniętych cylindrycznie warstw grafenowych. Układy te charakteryzują wyjątkowe właściwości fizykochemiczne, dlatego mogą być wykorzystane między innymi w nanomedycynie jako nośniki leków lub środki kontrastujące w obrazowaniu MRI. Z powodu silnych tendencji do agregacji nanorurek, problemem jest przygotowanie jednorodnej zawiesiny NW w wodzie, odseparowanie poszczególnych nanorurek, oraz ich rozdzielenie przy zachowaniu pierwotnych właściwości.

MATERIAŁ I METODA: Do określenia możliwości stabilizacji roztworów NW w wodzie wykorzystano szerokie spektrum surfaktantów, i scharakteryzowano badane zawiesiny je za pomocą metod UV/Vis, NMR i AFM. Badania toksyczności roztworów NW z surfaktantami w wodzie przeprowadzone zostały na liniach komórkowych HeLa.

WYNIKI: Wyniki przeprowadzonych badań mogą posłużyć do wyznaczenia toksyczności oraz stopnia dyspersji nanorurek węglowych w wodzie, pozwalając na zastosowanie ich jako m.in. nośniki leków, lub środki kontrastujące.

WNIOSKI: Zastosowanie trimerycznych, dimerycznych i monomerycznych związków powierzchniowo czynnych ze względu na formowanie się przez cząsteczki surfaktantów sterycznych barier na powierzchni nanorurek węglowych, może pozwolić na rozseparowanie nanomateriałów węglowych i tworzyć ich stabilne zawiesiny w wodzie. Tego rodzaju bariera mogłaby zredukować toksyczność NW, pozwalając na opracowanie nowych zastosowań aplikacyjnych w medycynie.

\section{EP-NT-066: Wpływ surfaktantów gemini na morfologię nanowstążek złota} Sylwia Haracz ${ }^{1}$, Maciej Kozak ${ }^{1}$

(1) Zakład Fizyki Makromolekularnej, Wydział Fizyki Uniwersytet im. Adama Mickiewicza w Poznaniu, Polska

WPROWADZENIE: Celem pracy było zbadanie wpływu struktury chemicznej dikationowych surfaktantów typu gemini na morfologię powstających nanowstążek złota uzyskiwanych metodą mokrej syntezy chemicznej. Układy tego typu mogą znaleźć zastosowanie jako komponenty nanosensorów o potencjalnym zastosowaniach w diagnostyce medycznej.

MATERIAŁ I METODA: Nanowstążki złota zostały otrzymane w procesie mokrej syntezy. Proces polegał na kilkukrotnej nukleacji na powierzchni wcześniej otrzymanych nanocząstek, bądź struktur pośrednich. W procesie syntezy stosowano dikationowe surfaktanty gemini posiadające różną budowę chemiczną. W zależności od struktury uzyskano nanowstążki charakteryzujące się odmienną morfologią.

WYNIKI: Otrzymane nanoukłady scharakteryzowano za pomocą transmisyjnej mikroskopii elektronowej oraz mikroskopii sił atomowych. Uzyskane wyniki mikroskopowe pozwoliły na potwierdzenie obecności nanowstążek złota badanych próbkach. Zaobserwowano oczekiwaną wydłużoną, spłaszczoną morfologię charakterystyczną dla nanowstążek.

WNIOSKI: Większość testowanych surfaktantów umożliwiało formowanie nanocząstek o oczekiwanej morfologii. W przypadku surfaktantów gemini zawierających pierścień imidazolowy otrzymano struktury w postaci nanowstążek charakteryzujące się najlepszą morfologią

EP-NT-067: Wpływ surfaktantów dikationowych na strukturę drugorzędową wybranych peptydów: N-terminalnego fragmentu ludzkiego białka prionowego i peptydu Ac-PEPTIDESNH 2

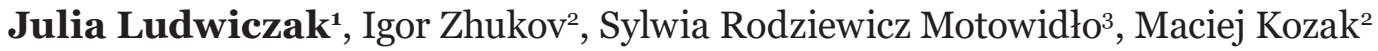

(1) Wydział Fizyki, Uniwersytet im. Adama Mickiewicza w Poznaniu, Poznań, Polska

(2) Zakład Fizyki Makromolekularnej, Wydział Fizyki, Uniwersytet im. Adama Mickiewicza w Poznaniu, Poznań, Polska

(3) Wydziat Chemii Uniwersytet Gdański, Polska 
WPROWADZENIE: Surfaktanty dikationowe (gemini) posiadające polane grupy imidazolowe mają zdolność do samoasocjacji i tworzenia złożonych nanostruktur w roztworach wodnych. Mogą także w roztworze indukować zmiany struktury drugorzędowej peptydów. Do badań wybrano serię surfaktantów gemini, peptyd zaprojektowany na bazie sekwencji ludzkiego białka prionowego (pozycje w sekwencji: 58-93) oraz referencyjny oktapeptyd o sekwencji Ac-PEPTIDES- NH 2. Ludzkie białko prionowe (PrP) o prawidłowej budowie posiada strukturę o przeważającej konformacji alfa-helikalnej. Nieprawidłowa konformacja tego białka (dominująca struktura beta-arkuszy w stosunku do alfa-helikalnej) jest przyczyną powstawania zakaźnych encefalopatii gąbczastych - chorób układu nerwowego ludzi i zwierząt. N-terminalna część białka PrP odpowiedzialna jest za wiązanie dwuwartościowych jonów metali ( $\mathrm{Zn} \mathrm{2+}, \mathrm{Cu} 2+$ ). Celem prowadzonych badań było zweryfikowanie wpływu wybranych do badań surfaktantów gemini na strukturę drugorzędową badanych peptydów.

MATERIAŁ I METODA: Badania obu peptydów w roztworze i w obecności surfaktantów gemini przeprowadzono przy użyciu metody spektroskopii dichroizmu kołowego (circular dichroism - CD). $\mathrm{Na}$ podstawie analizy widm CD, otrzymanych dla serii roztworów o różnych stosunkach molowych surfaktant:peptyd, przeprowadzonych za pomocą platformy DICHROWEB oszacowano awartość procentową poszczególnych elementów struktury drugorzędowej.

WYNIKI: Peptyd prionowy ludzki w buforze fosforanowym pH 5,82 $10 \mathrm{mM}$ ma 1,45 \% alfa-helis, $46 \%$ beta-kartek , 9,95 \% zakrętów i 40,6 \% struktur nieuporządkowanych. Wraz ze wzrostem długości łącznika surfaktantu geminii rośnie zawartość alfa-helis, a maleje zawartość beta-kartek. Peptyd Ac-PEPTIDESNH2 w buforze fosforanowym pH 5,82 10 mM zawiera 6,3\% alfa-helis, 40,1 \% beta-kartek, 13,2 \% zakrętów i 40,3\% struktur nieuporządkowanych. Po dodaniu surfaktantów gemini imidazolowych nie ma znaczących różnic w zawartości struktur drugorzędowych.

WNIOSKI: Dla peptydu (58-93) ludzkiego białka prionowego zaobserwowano, że wraz ze wzrostem długości grupy łącznika w strukturze imidazolowego surfaktantu gemini następuje wzrost zawartości struktury alfahelikalnej, a maleje zawartość arkuszy beta. Natomiast wykorzystywane w badaniach surfaktanty gemini imidazolowe nie indukują zmian struktury drugorzędowej referencyjnego peptydu Ac-PEPTIDES- NH 2.

[Zaprezentowane badania wykonano w ramach projektu o numerze 2014/15/B/ST4/o4839, finansowanego przez Narodowe Centrum Nauki].

\section{EP-NT-068: Badanie metodą ESR funkcjonalizowanych nanocząstek magnetytu pod kątem ich zastosowania w medycynie}

Bernadeta Dobosz ${ }^{1}$, Ryszard Krzyminiewski ${ }^{1}$, Grzegorz Schroeder ${ }^{2}$, Joanna Kurczewska²

(1) Zakład Fizyki Medycznej, Wydział Fizyki UAM, Poznań, Polska

(2) Zakład Chemii Supramolekularnej, Wydziat Chemii UAM, Poznań, Polska

WPROWADZENIE: Celem pracy jest pokazanie przydatności metody elektronowego rezonansu spinowego (ESR) do badania nanocząstek o potencjalnych zastosowaniach w medycynie.

MATERIAŁ I METODA: Przedmiotem badań były nanocząstki magnetytu funkcjonalizowane wybranym lekiem lub znacznikiem spinowym TEMPO, który może pełnić rolę zmiatacza reaktywnych form tlenu. Główną metodą zastosowaną w badaniach był elektronowy rezonans spinowy (ESR).

WYNIKI: Otrzymane wyniki umożliwiły ocenę własności magnetycznych funkcjonalizowanych nanocząstek oraz ich oddziaływania z materiałem biologicznym np. krwią ludzką, surowicą itp. Dodatkowo możliwa była ocena wpływu pokrycia oraz rozpuszczalnika a także procesu starzenia się nanocząstek.

WNIOSKI: Metoda ESR bardzo dobrze nadaje się do badania właściwości różnego typu funkcjonalizowanych nanocząstek oraz ich oddziaływania z materiałem biologicznym. 


\section{Plakat elektroniczny: Biosygnały [EP-BS]}

EP-BS-069: Wykorzystanie tympanometrii szerokopasmowej w diagnostyce ucha środkowego Olgierd Stieler ${ }^{1}$, Dorota Hojan-Jezierska ${ }^{1}$, Wawrzyniec Loba ${ }^{1}$, Marta Urbaniak ${ }^{1}$, Manuela Schlaffke ${ }^{1}$

(1) Zakład Protetyki Stuchu Katedra Biofizyki Uniwersytetu Medycznego w Poznaniu, Poznań, Polska

WPROWADZENIE: Celem badań była ocena sprawności ucha środkowego w grupie studentów, seniorów oraz u osób poddanych regularnej ekspozycji wysokich ciśnień - nurków. Celem pośrednim jest również wstępna ocena jakościowa metody tympanometrii (audiometrii impedancyjnej) szerokopasmowej w stosunku do metody klasycznej.

MATERIAŁ I METODA: Na referencyjną grupę studentów złożyło się 30 osób, 7 mężczyzn i 23 kobiety w wieku od 23 do 29, przy średniej wieku 24,1. W ramach akcji „Senioralni”, przebadane zostały osoby w wieku 6o+, przebadanych zostało 20 osób, w tym 5 mężczyzn i 15 kobiet. Najmłodsza osoba w grupie miała 60 lat a najstarsza 88, średnia wieku to 70,2 lat. Oprócz testu sprawności ucha środkowego, w obu grupach, wykonano badanie audiometrii tonalnej w celu oceny stanu słuchu. Dzięki możliwości współpracy z dwiema poznańskimi szkołami nurkowania wykonano badania pilotażowe u grupy 32 nurków. W badaniach brało udział 32 osób, 22 mężczyzn i 10 kobiet w wieku od 10- 65 lat. Staż nurkowy w badanej grupie obejmował okres od kilku miesięcy do 17 lat. Ostatnie nurkowania wykonano w okresie od 3 miesięcy do dnia poprzedzającego badania. Maksymalna głębokość nurkowania 50 metrów. Wykonano klasyczne badanie audiometrii impedancyjnej (tympanogram, $226 \mathrm{~Hz}$ ) za pomocą tympanometru klinicznego Madsen Midimate 901 Zodiac celem oceny kondycji ucha środkowego i późniejszego porównania wyników. Następnie wykonano badanie w szerokim zakresie częstotliwości bodźca na testowanym sprzęcie Interacoustic Titan.

WYNIKI: Dane poddano dokładnej analizie w odniesieniu do danych referencyjnych dla dużej populacji. WNIOSKI: Na etapie analizy statystycznej trwa opracowanie wyników tympanogramów typu 3D, które oferuje nowa metoda. Interesujący jest fakt, że w populacji tak bardzo narażonej na ekspozycję zarówno dużych, jak i szybkozmiennych wartości ciśnienia otoczenia, wychłodzenie i długotrwałą w dziedzinie czasu ekspozycję na takie warunki, stwierdzono w badaniach prawidłowy, fizjologiczny obraz zapisów zarejestrowanych w badaniach.

\section{EP-BS-070: Wyznaczenie normy wzrokowych potencjałów wywołanych}

Piotr Romański', Magdalena Grajek ${ }^{2}$

(1) Zakład Fizyki Medycznej, Wielkopolskie Centrum Onkologii, Poznań, Polska

(2) Zakład Elektroniki Kwantowej, Wydziat Fizyki, Uniwersytet im. Adama Mickiewicza, Poznań, Polska

WPROWADZENIE: Celem przeprowadzonych badań było ustalenie normy wzrokowych potencjałów wywołanych w grupie wiekowej 20-30 lat osób zdrowych.

MATERIAŁ I METODA: W badaniach VEP (Visual Evoked Potentials) wzięło udział 6o osób w wieku 20-28 lat. Osoby te musiały spełnić kilka kryteriów: wiek 20-30 lat, brak wady wzroku lub ewentualnie do wartości nie większej niż 0,5 dioptrii oraz brak chorób neurologicznych. Badania były wykonywane jednoocznie, w lekko oświetlonym pomieszczeniu oraz przy zachowaniu odpowiedniej ciszy. Bodźcem stymulującym aktywność kory wzrokowej była czarno-biała szachownica z polami zmieniającymi się z określoną częstotliwością oraz z położonym centralnie punktem fiksacji. Wykorzystywano dwie szachownice o różnych wielkościach pól. WYNIKI: Krzywe wzrokowych potencjałów wywołanych analizowano pod względem latencji i amplitudy pików N75, P100 oraz N145.

Oznaczenia: OS - oko lewe, OD - oko prawe, 15 i 60 - wielkości kątowe pól szachownicy.

Wartości latencji (średnia $[\mathrm{ms}] \pm 2 \mathrm{SD}[\mathrm{ms}]$ ) wyniosły odpowiednio:

dla piku N75:

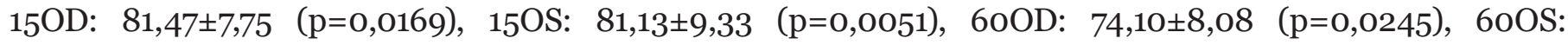

$74,13 \pm 10,04(\mathrm{p}=0,0461)$.

dla P100:

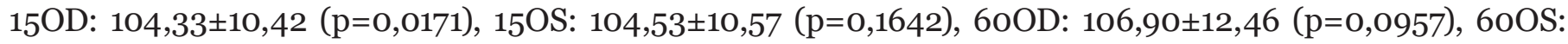


$106,53 \pm 8,99(\mathrm{p}=0,0011)$.

dla N145:

15OD: 151,20 $\pm 21,86(\mathrm{p}=0,2259), 15 \mathrm{OS}: 152,00 \pm 19,54(\mathrm{p}=0,2254), 60 \mathrm{OD}: 155,80 \pm 23,80$ ( $\mathrm{p}=0,0006), 600 S$ : $155,87 \pm 22,14(\mathrm{p}=0,0178)$.

Wartości amplitudy(średnia $[\mu \mathrm{V}] \pm 2 \mathrm{SD}[\mu \mathrm{V}]$ ) wyniosły odpowiednio:

dla piku N75:

15OD: $-8,79 \pm 11,21$ ( $\mathrm{p}=0,0116), 15 \mathrm{OS}:-8,11 \pm 11,28$ ( $\mathrm{p}=0,0062), 60 \mathrm{OD}:-4,57 \pm 7,34$ ( $\mathrm{p}=0,0120), 600 \mathrm{~s}:-4,41 \pm 6,93$ $(\mathrm{p}=0,1860)$.

dla P100:

15OD: 7,80 $\pm 10,60 \quad(p=0,3021), 15 O S: 7,96 \pm 10,08 \quad(p=0,0664), 60 O D: 9,80 \pm 9,38 \quad(p=0,5988), 60 O S$ : $9,80 \pm 10,39(\mathrm{p}=0,1892)$.

dla N145:

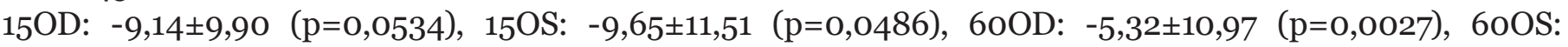
$-5,90 \pm 11,59(\mathrm{p}=0,1265)$.

WNIOSKI: Analizowane wyniki wzrokowych potencjałów wywołanych były efektem stymulacji oka wzorem czarno-białej szachownicy o różnych rozmiarach pola. Wielkość pól wpływała na wartości latencji i amplitudy. Wyznaczone wielkości w przypadku tej samej szachownicy w obu oczach były bardzo zbliżone.

Dla pików P10o i N145, zarówno dla oka prawego jak i lewego, przy większych polach występowało wydłużenie latencji w porównaniu z wartościami dla mniejszych pól. Przy większych polach szachownicy następowało również zmniejszenie bezwzględnej wartości amplitudy dla pików negatywnych N75 i N145.

Pomiar VEP są przydatne w diagnostyce schorzeń układu nerwowego, najczęściej stwardnienia rozsianego. Badanie to nie może jednak stanowić kryterium rozstrzygającego, czy dana osoba choruje na SM, lecz jedynie podtrzymywać lub poddać wątpliwości wcześniej postawioną diagnozę.

\section{EP-BS-071: Wpływ zewnętrznego bodźca akustycznego na stabilność posturalną}

Anna Majewska ${ }^{1}$, Dorota Hojan-Jezierska ${ }^{1}$, Weronika Kawałkiewicz² ${ }^{2}$ Leszek Kubisz ${ }^{2}$, Marta Urbaniak ${ }^{1}$, Dariusz Komar ${ }^{1}$

(1) Zakład Protetyki Stuchu, Katedra Biofizyki, Uniwersytet Medyczny im. Karola Marcinkowskiego w Poznaniu, Poznań, Polska

(2) Zakład Biofizyki, Katedra Biofizyki, Uniwersytet Medyczny im. Karola Marcinkowskiego w Poznaniu, Poznań, Polska

WPROWADZENIE: Badanie posturograficzne pozwala na obiektywną ocenę układu równowagi człowieka. Podczas badania wykonuje się zarówno pomiary położenia środka ciężkości na platformie nieruchomej posturografia statyczna, jak i na platformie niestabilnej - posturografia dynamiczna. Ruch platformy ma za zadanie odzwierciedlać sytuacje występujące podczas codziennej aktywności pacjenta. Niestabilność platformy w zależności od modelu i producenta urządzenia uzyskiwana jest poprzez umieszczenie pod stopami pacjenta piankowej poduszki bądź zawieszenie platformy na sprężynach. Celem pracy była ocena wpływu bodźca akustycznego o częstotliwości $4000 \mathrm{~Hz}$ i natężeniu 65 dB na stabilność posturalną człowieka, oceniana z wykorzystaniem trzech platform posturograficznych, w których zastosowano różne mechanizmy pozwalające na wykonanie badań dynamicznych.

MATERIAŁ I METODA: W badaniu wzięło udział 10 pacjentów w wieku 20-35 lat. Kryterium wykluczającym z badań był niedosłuch oraz zaburzenia równowagi lub zawroty głowy. Do oceny stabilności posturalnej wykorzystano trzy platformy posturograficzne: Multitest Equilibre firmy FRAMIRAL, ICS Balance Platform firmy Otometrics oraz MediBalance Pro firmy MediTECH.

WYNIKI: Pomiary wykonywano w obecności bodźca akustycznego o częstotliwości $4000 \mathrm{~Hz}$ i natężeniu $65 \mathrm{~dB}$ oraz bez dodatkowych czynników zakłócających. Analizowano parametry takie jak: prędkość i powierzchnia zakreślona przez rzut środka ciężkości.

WNIOSKI: W przypadku oceny prędkości błądzenia środka ciężkości parametrów zaobserwowaną istotną statystycznie różnicę między pomiarami bez bodźca dźwiękowego oraz w obecności bodźca akustycznego o częstotliwości $4000 \mathrm{~Hz}$ i natężeniu $65 \mathrm{~dB}$. 
EP-BS-072: Wykorzystanie laserowej wibrometrii Dopplerowskiej do pomiaru drgań czaszki Weronika Kawałkiewicz ${ }^{1}$, Anna Majewska ${ }^{2}$, Jerzy Sokalski ${ }^{3}$, Dorota Hojan-Jezierska², Leszek Kubisz ${ }^{1}$

(1) Zakład Biofizyki, Katedra Biofizyki, UM w Poznaniu, Poznań, Polska

(2) Zakład Protetyki Stuchu, Katedra Biofizyki, UM w Poznaniu, Poznań, Polska

(3) Katedra i Klinika Chirurgii Stomatologicznej, UM w Poznaniu, Poznań, Polska

WPROWADZENIE: Laserowa wibrometria Dopplerowska należy do bezkontaktowych metod pomiaru drgań. Znalazła zastosowanie w wielu dziedzinach, zarówno w przemyśle jak i w medynie. Metoda ta wykorzystana została do pomiaru drgań czaszki wywołanych ruchem w stawie skroniowo-żuchwowym. Stawy skroniowo-żuchwowe to stawy, które łączą kość skroniową

z żuchwą. Odpowiadają za wykonywanie ruchów w trzech płaszczyznach: opuszczanie/podnoszenie żuchwy, przesuwanie żuchwy na boki oraz wysuwanie żuchwy do przodu.

MATERIAŁ I METODA: Pomiary drgań czaszki wykonane zostały zarówno u pacjentów bez dysfunkcji stawów skroniowo-żuchwowych jak i u pacjentów z dysfunkcjami stawów, podczas każdego

z ruchów za które odpowiadają wyżej wymienione stawy.

WYNIKI: Metoda, która została wykorzystana do pomiaru drgań czaszki jest laserowa wibrometria Dopplerowska. Jak już wspomniano jest to metoda, która pozwala na bezkontaktowy pomiar drgań. Dzięki czemu eliminowane są zakłócenia, mogące wynikać z masy czujników pomiarowych bądź temperatury badanego obiektu. Wiązka lasera He-Ne nakierowana zostaje kolejno na oba stawy i wykonywane są pomiary podczas wyżej opisanych ruchów żuchwy.

WNIOSKI: Na podstawie uzyskanych wyników można zaobserwować różnice częstotliwości drgań czaszki u osób z dysfunkcjami stawów skroniowo-żuchwowych oraz u osób nie objętych tą dysfunkcją.

\title{
Plakat elektroniczny: Ochrona Radiologiczna [EP-OR]
}

\author{
EP-OR-073: Ocena narażenia skóry i soczewek oczu na promieniowanie jonizujące na \\ podstawie pomiarów Laboratorium Dozymetrii Indywidualnej i Środowiskowej IFJ PAN. \\ Magdalena Michalska ${ }^{1}$, Katarzyna Soból ${ }^{1}$, Anna Sas-Bieniarz ${ }^{1}$, Agata Toboła ${ }^{1}$, Paulina Janowska ${ }^{1}$, Anna \\ Serwicka ${ }^{1}$, Aleksandra Kiszkurno ${ }^{1}$, Gabriela Glaz ${ }^{1}$, Maciej Budzanowski ${ }^{1}$, Izabela Milcewicz-Mika ${ }^{1}$ \\ (1) Instytut Fizyki Jądrowej im. H. Niewodniczańskiego Polskiej Akademii Nauk, Kraków, Polska
}

WPROWADZENIE: Współczesny rozwój technologii powoduje coraz częstsze wykorzystywanie promieniowania jonizującego w wielu dziedzinach działalności człowieka. Promieniowanie to może być szkodliwe dla zdrowia w związku z czym niezbędne są działania prowadzące do zminimalizowania ryzyka narażenia zawodowego ludzi pracujących z promieniowaniem oraz ciągłość kontroli poziomu ich narażenia. MATERIAŁ I METODA: W Laboratorium Dozymetrii Indywidualnej i Środowiskowej IFJ PAN prowadzone są pomiary dawek promieniowania jonizującego dla osób narażonych zawodowo przy pomocy nowoczesnych dawkomierzy TLD. LADIS wykonuje pomiary indywidualnego równoważnika dawki na całe ciało $\mathrm{Hp}(10)$, indywidualnego równoważnika dawki na dłonie $\mathrm{Hp}(0,07)$ oraz soczewki oczu Hp(3). Rocznie laboratorium wykonuje pomiary dla ponad 8000 instytucji z całego kraju.

W przypadku dozymetrii zewnętrznego narażenia na skórę używane są dawkomierze pierścionkowe pozwalające wyznaczyć indywidualny równoważnik dawki na skórę $\mathrm{Hp}(0,07)$ na głębokości d=0,07 mm $\mathrm{w}$ polach promieniowania fotonowego. Laboratorium LADIS stosuje $\mathrm{w}$ tym celu termoluminescencyjne detektory (TL) typu MTS-N (LiF: Mg, Ti).

W ostatnich latach wzrosło również zainteresowanie oceną dawek na soczewki oczu

w radiologii interwencyjnej. Obserwowany wzrost zainteresowania jest związany z faktem, iż zaćma może być indukowana przez dawki promieniowania na poziomie niższym niż dotychczas sądzono. W odpowiedzi na nowe dane, Międzynarodowa Komisja Ochrony Radiologicznej (ICRP) zaleciła zmniejszenie limitu dawki rocznej na soczewki oczu z $150 \mathrm{mSv}$ do $20 \mathrm{mSv}$. Dawkomierze indywidualne noszone na tułowiu czy dawkomierze pierścionkowe nie są jednak wystarczające i nie dają możliwości poprawnego oszacowania 
takiego narażenia. Z tego powodu konieczne jest stosowanie dawkomierzy dedykowanych do oceny narażenia soczewek oczu. Od lutego 2012 w laboratorium LADIS wprowadzono pomiar dawek Hp(3) na soczewki oczu przy użyciu detektorów termoluminescencyjnych typu MCP-N (LiF:Mg,Cu,P).

WYNIKI: W pracy przedstawione zostaną wyniki pomiarów indywidualnych równoważników dawek na skórę oraz soczewki oczu przeprowadzone przez laboratorium LADIS w latach 2014-2016. Pomiary wykonywane były głównie w systemie kwartalnym.

WNIOSKI: Dawkomierze pierścionkowe oraz oczne stosowane są głównie przez osoby pracujące w narażeniu na promieniowanie jonizujące w szpitalach: radiolodzy interwencyjni, pracownicy medycyny nuklearnej, pracownicy centrów onkologii.

EP-OR-074: Ocena indywidualnego równoważnika dawki na całe ciało Hp(10) w wybranych placówkach wykorzystujących promieniowaniejonizujące w celach medycznych na podstawie pomiarów Laboratorium Dozymetrii Indywidualnej i Środowiskowej IFJ PAN

Renata Kopeć ${ }^{1}$, Agnieszka Pasieka ${ }^{1}$, Paulina Majczak-Ziarno ${ }^{1}$, Barbara Dzieża ${ }^{1}$, Katarzyna Włodek ${ }^{1}$, Katarzyna Chrul ${ }^{1}$, Magdalena Kościńska ${ }^{1}$, Małgorzata Kruk ${ }^{1}$, Paweł Bednarczyk ${ }^{1}$, Izabela Milcewicz-Mika ${ }^{1}$

(1) Instytut Fizyki Jądrowej im. H. Niewodniczańskiego Polskiej Akademii Nauk, Kraków, Polska

WPROWADZENIE: Powszechność stosowania promieniowania jonizującego w medycynie, głównie w celach diagnostyki oraz leczenia pacjenta, wiąże się z prowadzeniem ciągłego monitoringu narażenia zawodowego personelu uczestniczącego w procedurach medycznych ze względu na szkodliwość promieniowania dla zdrowia człowieka.

MATERIAE I METODA: W Laboratorium Dozymetrii Indywidualnej i Środowiskowej IFJ PAN prowadzone są pomiary dawek promieniowania jonizującego dla osób narażonych zawodowo przy pomocy nowoczesnych dawkomierzy TLD. LADIS wykonuje pomiary indywidualnego równoważnika dawki na całe ciało $\mathrm{Hp}(10)$, indywidualnego równoważnika dawki na dłonie $\mathrm{Hp}(0,07)$ oraz soczewki oczu Hp(3). Rocznie laboratorium wykonuje pomiary dla ponad 8000 instytucji z całego kraju.

W przypadku dozymetrii całego ciała wykorzystywane są dawkomierze typu DI-02 pozwalające wyznaczyć indywidualny równoważnik dawki $\mathrm{Hp}(10)$ na głębokości $\mathrm{d}=10 \mathrm{~mm}$ informujący o narażeniu narządów wewnętrznych na promieniowanie jonizujące. Laboratorium LADIS stosuje w tym celu termoluminescencyjne detektory (TL) typu MTS-N (LiF: Mg, Ti).

WYNIKI: W pracy przedstawione zostaną wyniki pomiarów indywidualnego równoważnika dawki na całe ciało Hp(10) przeprowadzone przez laboratorium LADIS w latach 2014-2016 w wybranych placówkach medycznych. Pomiary dla których zostaną przedstawione dane dokonywane były w systemie kwartalnym.

WNIOSKI: Rzetelna kontrola dawek pracowników pozwala nadzorować poziom narażenia zawodowego, a tym samym prawidłowość stosowania procedur dotyczących ochrony radiologicznej personelu.

\section{EP-OR-075: Organizacja Zakładu Medycyny Nuklearnej - Pracownia Izotopowa klasy II Sylwia Wiśniewska - Kubka ${ }^{1}$}

(1) Zakład Medycyny Nuklearnej Dolnośląski Szpital Specjalistyczny im.T.Marciniaka - Centrum Medycyny Ratunkowej we Wrocławiu, Wroctaw, Polska

WPROWADZENIE: Organizacja Zakładu Medycyny Nuklearnej

MATERIAŁ I METODY: Zanim podejmiemy działania mające na celu stworzenie Zakładu Medycyny Nuklearnej należy dokładne przemyśleć jakie rodzaje badań mamy zamiar wykonywać, a co za tym idzie jakie radioizotopy i ich aktywności będą nam do tego potrzebne.Przy diagnostycznym i terapeutycznym stosowaniu izotopów promieniotwórczych działania związane z ochroną radiologiczną zakładu medycyny nuklearnej są ściśle związane z zakresem ochrony radiologicznej pracowni izotopowej klasy II (o klasie pracowni decyduje aktywność stosowanych jednocześnie izotopów promieniotwórczych i ich przynależność do grupy izotopów promieniotwórczych).Jeśli podjęliśmy już decyzję co do rodzaju i zakresu stosowanych izotopów w naszym zakładzie możemy przejść do kolejnych kroków, mianowicie do ustalenia z jaką klasą 
pracowni będziemy mieć do czynienia. Wymagania techniczne, budowlane i wyposażenie ściśle wiąże się z określoną klasą pracowni.

WYNIKI: Wymogi techniczne i organizacyjne dotyczące Zakładów Medycyny Nuklearnej, a dokładniej rzecz ujmując Pracowni izotopowej klasy II opisane są w ustawie Prawo atomowe i rozporządzeniach towarzyszących. W Zakładzie Medycyny Nuklearnej w badaniach diagnostycznych mogą być stosowane praktycznie wszystkie izotopy użytkowane zgodnie z aktualnym stanem wiedzy do badań na gamma kamerach.

WNIOSKI: Organizacje i wyposażenie pracowni izotopowej zarówno w sprzęt podstawowy jak i pomocniczy należy uwzględnić już przy specyfikowaniu zapytań ofertowych. Istotną kwestią jest również zapewnienie personelowi szkoleń z obsługi nowego wyposażenia, zagwarantowanie przez dostawcę sprzętu odpowiedniego okresu serwisowania urządzeń, ilości i zakresu przeglądów, dostępu do oprogramowania i wsparcia technicznego on line.

\section{EP-OR-076: Ochrona radiologiczna pacjenta stomatologii.}

Anna Marcinkowska-Gapińska ${ }^{1}$, Marlena Gauza-Włodarczyk ${ }^{1}$, Zofia Kiersznowska ${ }^{2}$

(1) Katedra i Zakład Biofizyki, Uniwersytet Medyczny w Poznaniu, Polska

(2) University of Medical Science in Łódź, Poland

WPROWADZENIE: Znajomość zagadnień związanych z ochroną radiologiczną jest bardzo ważną dziedziną we współczesnej medycynie.

MATERIAŁI METODA: Wiele metod diagnostycznych iterapeutycznych związanych jest zwykorzystaniem promieniowania jonizującego. Ochrona radiologiczna obejmuje zarówno personel jak i pacjenta. Gabinety stomatologiczne często wyposażone są w aparaty rentgenowskie, co związane jest z opracowaniem odpowiednich procedur postępowania.

WYNIKI: W niniejszej pracy omówiono dawki i jednostki promieniowania oraz przedstawiono biologiczne skutki promieniowania na żywe organizmy. Poruszono również podstawy prawne związane z ochroną radiologiczną pacjenta $\mathrm{w}$ gabinecie stomatologicznym oraz zwrócono uwagę na potrzebę opracowania procedur roboczych na podstawie wzorcowych procedur przedstawionych $\mathrm{w}$ przepisach związanych $\mathrm{z}$ ochroną radiologiczną.

WNIOSKI: W podsumowaniu podkreślono, że zwiększająca się liczba aparatów rentgenowskich w gabinetach stomatologicznych pociąga za sobą konieczność śledzenia zmian w prawie i dostosowywania na bieżąco działalności tych gabinetów do przepisów prawa atomowego.

\section{Plakat elektroniczny: Brachyterapia [EP-BT]}

\section{EP-BT-077: Parametryczna ocena rozkładów dawek uzyskanych śródtkankową brachyterapią HDR w leczeniu uzupełniającym i radykalnym nowotworów zlokalizowanych w obrębie głowy i szyi.

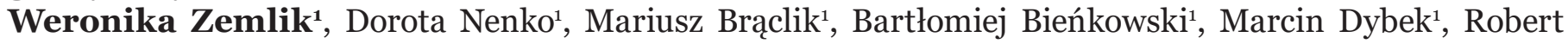
Kwiatkowski ${ }^{1}$

(1) Zakład Radioterapii, Katowickie Centrum Onkologii, Katowice, Polska

WPROWADZENIE: Celem pracy była ocena jakości rozkładów dawek przy pomocy następujących parametrów: V100, D90, CI, COIN, DNR, DHI, Dśr dla pacjentów z nowotworami w obszarze głowy i szyi leczonych techniką śródtkankowej brachyterapii HDR

MATERIAŁ I METODA: Materiał badawczy stanowiły rozkłady dawek obliczonych dla 10 pacjentów leczonych w okresie czerwiec-grudzień 2016r. w Zakładzie Radioterapii w Katowickim Centrum Onkologii. Dawka zaplanowana wyniosła $45 \mathrm{~Gy} / 15 \mathrm{fr}$. Do aplikacji użyto jednorazowych, plastikowych, aplikatorów giętkich. Średnia ilość wykorzystanych aplikatorów na pacjenta wyniosła 4 (zakres 3-6). Dla wszystkich 
pacjentów wykonano obrazowanie tomografią komputerową z zastosowaniem warstw o szerokości $2 \mathrm{~mm}$. Do optymalizacji rozkładu dawki użyto metody manualnej i graficznej wagowania czasów postoju źródła. Rozkład dawki obliczono przy pomocy systemu Oncentra Brachy z zaimplementowanym algorytmem bez korekcji niejednorodności, zgodnym z protokołem TG-43 (AAPM).

WYNIKI: Otrzymano następujące średnie wartości parametrów (średnia): V100=81.45 \%; D90= 90,90\%; $\mathrm{DNR}=0,55 ; \mathrm{DHI}=0,45 ; \mathrm{COIN}=0,68 ; \mathrm{CI}=0,83 ; \mathrm{Dś} r=180,77 \%$.

WNIOSKI: Zastosowanie brachyterapii śródtkankowej w leczeniu uzupełniającym daje możliwość podania dawki 45 Gy w obszarze wysokiego ryzyka związanym z lokalizacją guza pierwotnego. Wysoka wartość parametru DNR i niska wartość parametru DHI wskazują na niejednorodny rozkład dawki. Uzyskana średnia parametru CI była niższa od rekomendowanej wartości 0,95.

EP-BT-078: Raport ICRU 89 w praktyce.

Magdalena Dymnicka ${ }^{1}$, Anna Kociemba ${ }^{1}$, Martyna Zawadzka $^{2}$, Barbara Drzewiecka ${ }^{1}$

(1) MCO Affidea $w$ Poznaniu, Polska

(2) Uniwersytet im. Adama Mickiewicza w Poznaniu, Polska

WPROWADZENIE: Celem pracy była analiza zaleceń dotyczących planowania leczenia brachyterapii ginekologicznej zawartych w nowym raporcie ICRU 89. Ocenie podlegały wartości parametrów rozkładu dawki oraz wartości dawek w punktach referencyjnych dla narządów krytycznych. Dodatkowo zbadano wpływ aplikatora na wybrane parametry dla objętości tarczowych.

MATERIAŁ I METODA: Analizie poddano 20 planów leczenia pacjentek z rakiem szyjki macicy leczonych z użyciem aplikatora typu Fletcher według schematu 4x7Gy. Plany leczenia wykonano w systemie planowania OncentraBrachy w wersji 4.5.2., na podstawie przekrojów MR wykonanych podczas pierwszej frakcji. Oprócz standardowych objętości tarczowych i narządów krytycznych wprowadzono proponowane w raporcie ICRU struktury dodatkowe uwzględniające aplikator oraz jelita. Następnie przeanalizowano wartości parametrów ujętych w zaawansowanym standardzie raportowania oraz wartości dawek w punktach referencyjnych.

WYNIKI: Przy zachowaniu dotychczas obowiązujących wartości parametrów limitujących dawkę dla objętości tarczowych otrzymano średnie wartości parametrów D100 79,5\%, 34,6\%, 20,4\%, D98 96,4\%, 46,3\%, 27,6\%, D90 114,3\%, 64,5\%, 38,8\% i D50 180,8\%, 130,1\%, 81,6\% odpowiednio dla GTV, HR CTV i IR CTV. Wykazano również istotną statystycznie różnicę w wartościach parametrów D9o i D50 dla objętości tarczowych przed i po uwzględnieniu aplikatora, przy czym wartości parametrów dla objętości pomniejszonej o aplikator były niższe.

Dla narządów krytycznych otrzymano wartości parametrów Do,1cm3 61,2\%, 92,1\%, 80,4\%, 73,6\%, D1cm3 47,5\%, 78,9\%, 65,7\%, 61,1\%, D2cm3 42,8\%, 72,8\%, 58,7\%, 55,8\%, D2 46,9\%, 78,5\%, 69,4\%, 48,4\%, D50 18,5\%, 34,4\%, 28,9\%, 16,6\% i D98 7,5\%, 17,3\%, 12,8\%, 5,5\% odpowiednio dla esicy, pęcherza, rectum i jelit. W zaproponowanych w raporcie punktach referencyjnych dla narządów krytycznych uzyskano średnie procentowe dawki dla pęcherza 66,9\% (45,9\%-88,1\%), dla rectum 66,9\% (32\%-102,9\%) i dla pochwy 34,9\% (12,7\%-185,8\%), 85,1\% (28,8\% - 190,5\%) i 13,1\% (69,0\%-45,8\%) odpowiednio w punktach środkowym, górnym i dolnym.

WNIOSKI: Raport ICRU ustandaryzował postępowanie w brachyterapii ginekologicznej i określił rozbudowane kryteria oceny planów leczenia i raportowania dawek. Wprowadzenie proponowanych zmian do codziennej praktyki wymaga jednak szczegółowej analizy poszczególnych parametrów rozkładów dawek, tym bardziej, że w raporcie dla większości z nich nie zostały podane liczbowe kryteria oceny. W dalszej perspektywie powinno się również oszacować wpływ wartości zaproponowanych parametrów na efekt terapeutyczny uwzględniający zarówno kontrolę miejscową guza jak i ewentualne powikłania w narządach krytycznych.

EP-BT-079: Analiza zaleceń Raportu 89 ICRU "Prescribing, Recording and Reporting Brachytherapy for Cancer of the Cervix" dotyczących specyfikacji i raportowania rozkładu dawki w brachyterapii raka szyjki macicy. 
Renata Kabacińska1 ${ }^{1}$, Judyta Wiercińska ${ }^{1,2}$, Paweł Trafara ${ }^{1}$, Roman Makarewicz ${ }^{2,3}$

(1) Zakład Fizyki Medycznej, Centrum Onkologii w Bydgoszczy, Polska

(2) Katedra i Klinika Onkologii i Brachyterapii, CM UMK w Bydgoszczy, Polska

(3) Oddział Kliniczny Brachyterapii, Centrum Onkologii w Bydgoszczy, Polska

WPROWADZENIE: Omówienie zaleceń Raportu ICRU 89 dotyczących specyfikacji i raportowania rozkładu dawki w brachyterapii raka szyjki macicy oraz porównanie ich z dotychczas stosowanymi metodami i rekomendacjami GEC-ESTRO. Analiza serii klinicznych planów leczenia pod względem zgodności z nowymi zaleceniami.

MATERIAŁI METODA: Przedstawiono dotychczas stosowane metody specyfikacji dawki związanezkermą całkowitą TRAK, dawką w punkcie A, dawką na izodozę referencyjną i parametrem D9o\% zalecanym przez GEC-ESTRO. Omówiono Raport 89 ICRU przygotowany wspólnie z GEC-ESTRO i opublikowany w czerwcu 2016 roku. Zgodnie z ICRU 89 proces planowania leczenia i specyfikacji dawki został przedefiniowany przez wprowadzenie tzw. ostatecznej specyfikacji dawki, będącej kompromisem między napromienianiem targetu-CTVHR i obciążeniem organów krytycznych dla indywidualnego pacjenta. Przeanalizowano 31 kolejnych klinicznych planów leczenia, zrealizowanych za pomocą standardowych aplikatorów typu tandem/ ring w latach 2015/2016. Dla tych planów wyznaczono zalecane przez ICRU 89 parametry: objętość targetu, TRAK, D9o\% dla targetu, dawkę w punkcie A, Do.1cm3 i D2cm3 dla pęcherza moczowego i odbytnicy. Oszacowano wartości tych parametrów w odniesieniu do zaleceń GEC-ESTRO oraz ICRU 89.

WYNIKI: Zalecana przez ICRU 89 zmiana polega na indywidualizacji specyfikacji dawki dla każdego przypadku klinicznego. Jednocześniezaleca sięraportowaniewiększości stosowanych dotychczas parametrów dozymetrycznych. Dla analizowanej serii planów klinicznych średnia objętość targetu wynosiła VCTVśr= 32.2 cm3 (SD+12.1), objętość ta zmieniała się znacząco w zakresie od $10.0 \mathrm{~cm} 3$ do $56.9 \mathrm{~cm} 3$. Istnieje ścisła korelacja między objętością targetu a całkowitą kermą TRAK (r=0.91). Wartość D90\% dla targetu zmieniała się w szerokim zakresie od 61.4\% do 107.9\% dawki frakcyjnej (D90\%śr=96.2\%). Niska wartość parametru D90\% dla kilku planów wynikała zwykle z konieczności ograniczenia dawki dla pęcherza moczowego lub odbytnicy.

WNIOSKI: Podstawowym problemem specyfikacji dawki w brachyterapii raka szyjki macicy jest duży gradient dawki, zróżnicowanie objętości i kształtu targetu oraz bliskość organów krytycznych. Zalecenia ICRU 89 dają większe możliwości indywidualnego dopasowania planu leczenia do sytuacji klinicznej. Raportowanie TRAK jest ważne ponieważ parametr ten związany jest z objętością targetu i odpowiada całkowitej zdeponowanej dawce pochłoniętej.

\section{EP-BT-080: Leczenie wznowy w nowotworach regionu głowy i szyi}

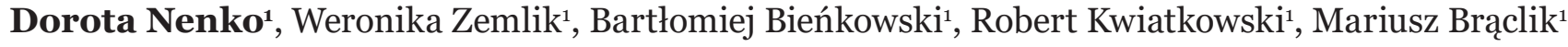

(1) Zakład Radioterapii, Katowickie Centrum Onkologii, Katowice, Polska

WPROWADZENIE: Ponowne napromienianie w regionie głowy i szyi stanowi wyzwanie ze względu na wzajemne położenie obszaru wznowy i struktur krytycznych

Celem pracy jest ocena skuteczności zastosowania EBRT i śródtkankowej 3D BRT HDR w leczeniu wznowy raka w regionie głowy i szyi.

MATERIAŁ I METODA: W okresie od 06-09.2016 przeprowadzono leczenie wznów nowotworów regionu głowy i szyi u 5 pacjentów, którzy uprzednio zastali poddani radioterapii radykalnej.

Średni czas do wystąpienia wznowy - 49 miesięcy.

Wybór metody leczenia był zależny od lokalizacji wznowy i stanu pacjenta.

Średnia liczba aplikatorów zastosowanych w BRT wynosila 7.

Oceniano wartości D90, V100, V150 oraz biologiczne dawki maksymalne dla narządów krytycznych

Plany EBRT zostały przygotowane w technikach VMAT oraz 3D CRT.

Oceniano D50 D2 D98 oraz biologiczne dawki maksymalne dla narządów krytycznych.

Dawka całkowita dla BRT HDR jako leczenia samodzielnego wynosiła 51-54Gy.

Pacjenci poddani leczeniu skojarzonemu otrzymali w I etapie EBRT w dawce 30,6Gy oraz w II etapie HDR 
w dawce 30Gy 2xdziennie.

Pacjenci u których zastosowano tylko EBRT otrzymali dawki 30,6 - 32,4Gy jako IIetap po uprzedniej chemioterapii lub EBRT.

WYNIKI: Czas obserwacji po zakończeniu leczenia powtórnego wynosi 7-8 miesięcy.

U wszystkich chorych obserwowano regresje nacieku nowotworowego, u 3 pacjentów stwierdzono martwicę tkankową w obszarze aplikacji brachyterapii, która po upływie 5-6 miesięcy ulegała stopniowej sekwestracji z wytworzeniem ubytku tkankowego w okolicy napromienianej. U pozostałych dwóch chorych obserwowano regresje całkowitą nacieku nowotworowego.

3 chorych wymagało stosowania opioidowych leków przeciwbólowych.

Jeden z pacjentów wymagał założenia PEG.

Nie obserwowano powikłań ze strony ślinianek - suchość jamy ustnej, u pacjentów poddanych brachyterapii obserwowano nasilenie odczynu wczesnego - epitelioliza, śluzówek jamy ustnej i języka.

WNIOSKI: Leczenie pacjentów u których doszło do wznowy nowotworowej po pierwotnym zastosowaniu radioterapii wymaga indywidualizacji postępowania z wykorzystaniem wszystkich dostępnych metod leczenia onkologicznego.

Właściwy dobór metody leczenia lub ich skojarzenie pozwala na uzyskanie kontroli miejscowej nowotworu z jednoczesnym ograniczeniem powikłań leczenia.

Wykorzystanie brachyterapii śródtkankowej jako składowej leczenia ratunkowego pozwala na podanie wysokiej dawki w obszarze guza przy jednoczesnym zaoszczędzeniu narządów krytycznych i zmniejszeniu nasilenia powikłań. Ze względu na niewielką objętość tkanek poddanych brachyterapii, objętość martwicy popromiennej była niewielka i ulegała wygojeniu po kilku miesiącach bez istotnych dla życia powikłań przetoki.

EP-BT-081: Wprowadzenie techniki napromieniania raka stercza, metodą brachyterapii śródtkankowej, w Dolnośląskim Centrum Onkologii

Jacek Walczak ${ }^{1}$, Honorata Ziemiańska ${ }^{1}$, Małgorzata Drobiazgiewicz ${ }^{1}$, Kazimierz Kulaszewski ${ }^{1}$, Katarzyna Konat $^{1}$, Urszula Staszek-Szewczyk ${ }^{1}$, Krystian Lichoń ${ }^{1}$, Marzena Janiszewska ${ }^{1}$

(1) Dolnośląskie Centrum Onkologii we Wrocławiu, Wrocław, Polska

WPROWADZENIE: Celem pracy jest zilustrowanie procesu doskonalenia techniki brachyterapii raka stercza w DCO we Wrocławiu, oraz przedstawienie wstępnych doświadczeń w tej dziedzinie.

MATERIAŁ I METODA: Proces planowania odbywa się za pomocą oprogramowania Vitesse firmy Varian, aparatu USG BK Medical flexFocus 500, EX3 Stepper CIVCO, sonda BK medical typ 8848, płytka fiksująca igły DK- TECH Fixation Template, GammaMed plus iX

WYNIKI: Prezentacja przykładowych rozkładów dawek, DVH, obrazy z systemu Vitesse,

WNIOSKI: Technikę brachyterapii w raku stercza stosujemy od lipca 2016. W tym czasie przeprowadziliśmy leczenie 40 pacjentów z rozpoznanym gruczolakorakiem prostaty, co daje nam 62 założenia na chwilę obecną. U pacjentów z samodzielną brachyterapią stosujemy dawkę całkowitą 30Gy, 15Gy na frakcję. U pacjentów tele+brachy stosujemy boost 15Gy w jednej frakcji. Pacjenci ze wznową leczeni są dawką 10Gy/frakcję do dawki całkowitej 30Gy.

Pomiary długości igieł wykonywane są przez dwóch fizyków niezależnie. Ma to na celu sprawdzenie poprawności wyznaczenia ich pozycji oraz długości w systemie z igłami umieszczonymi w płytce fiksującej. Przed zeskanowaniem prostaty ustawiony zostaje margines poza podstawę prostaty ze względu na możliwość przesunięcia się prostaty w kierunku pęcherza. Lekarz zwraca uwagę na to aby zawsze widoczny był balon w pęcherzu, wtedy można dokłuć igły poza stercz celem objęcia podstawy prostaty, nawet za cenę zranienia pęcherza i krwiomoczu. Skanowanie prostaty przy pomocy USG odbywać się musi w sposób ciągły i powolny. Unika się w ten sposób artefaktów na obrazie. Pod koniec skanowania prostaty z wbitymi igłami włączona zostaje siatka na USG, ułatwia to lekarzowi konturowanie targetu. Zeskanowany obraz zawierać musi widok szczytu co najmniej jednej igły ( wymóg programu Vitesse ), którą fizyk wyznacza z dużą dokładnością w celu oznaczenia jej jako referencyjnej.

Przy prostatach o większej objętości, nogi pacjenta dociskane są w kierunku klatki piersiowej co zmniejsza 
na obrazie efekt interferencji igieł z łukiem kości miednicy. Spostrzeżono, że w przypadku gdy nie widać igły na obrazie, należy odblokowywać płytkę z igłami, co niejednokrotnie skutkuje wysunięciem się igieł, determinując ponowne skanowanie i identyfikację aplikatorów.

\title{
Plakat elektroniczny: Teleradioterapia [EP-TT]
}

\author{
EP-TT-082: Analiza możliwości wprowadzenia adaptacyjnej metody napromieniania (ART) \\ u chorych z rakiem pęcherza moczowego pod kontrolą obrazową IGRT \\ Maria Poncyliusz ${ }^{1}$, Maria Piziorska ${ }^{1}$, Beata Czyżew ${ }^{1}$, Joanna Chorąży ${ }^{1}$, Dorota Blatkiewicz ${ }^{1}$, Paweł \\ Kukołowicz ${ }^{1}$ \\ (1) Zakład Fizyki Medycznej, Centrum Onkologii-Instytut im. Marii Skłodowskiej-Curie w Warszawie, Polska
}

WPROWADZENIE: Obecnie u pacjentów z nowotworem pęcherza moczowego, w celu zapewnienia, że podana zostanie pełna dawka terapeutyczna, niezbędne jest dodawanie do obszaru CTV marginesu o wartości około $1,5 \mathrm{~cm}$. Celem pracy było zweryfikowanie możliwości wprowadzenia adaptacyjnej metody napromieniania (ART), pozwalajacej zmniejszyć napromieniany obszar tkanek zdrowych. W tym celu wykonywane będą trzy tomografie do planowania leczenia. Realizacja tej metody ma polegać na wyborze w danym dniu jednego z trzech przygotowanych wcześniej planów leczenia na tomografiach komputerowych z różnymi wypełnieniami pęcherza oraz różnymi marginesami. Realizowany plan ma być wybierany w oparciu o dane obrazowe uzyskane z wykorzystaniem CBCT. W pierwszym etapie pracy analizowano powtarzalność wypełnienia pęcherza w czasie trwania radioterapii.

MATERIAŁ I METODA: Przeanalizowano wyniki badań obrazowych dla czterech pacjentów napromienianych w 2016r konwencjonalną techniką konformalną. Margines CTV-PTV wynosił 1,5cm. Przed każdym seansem terapeutycznym wykonywano badanie CBCT. W sumie uzyskano 81 zestawów obrazów. W każdym zestawie obrazów wrysowywano kontury zewnętrzne pęcherza i następnie określano objętości pęcherza w sesji terapeutycznej. Następnie przeanalizowano zmiany objętości pęcherza moczowego. Uzyskane wyniki odnoszono do objętości pęcherza wyznaczonej podczas badania CT do planowania leczenia. Określono liczność wystąpień objętości pęcherza w przedziałach co $10 \mathrm{~cm} 3$.

WYNIKI: W 69 sesjach terapeutycznych objętość pęcherza była mniejsza od objętości referencyjnej. W 51 przypadków objętość pęcherza znajdowała się w przedziale od 40\% do 80\% objętości referencyjnej. W 24 przypadkach sesji terapeutycznych pęcherz miał objętość do o,5 wartości referencyjnej, w 48 frakcjach objętość pęcherza mieściła się w przedziale 0,5 do 1 objętości referencyjnej pęcherza, tylko w 3 przypadkach objętość pęcherza była porównywalna z zaplanowaną, a w 6 przypadkach objętość pęcherza mieściła się w przedziale od 1,1 do 2 w stosunku do objętości pęcherza na CT do planowania.

WNIOSKI: Na podstawie otrzymanych wyników uzasadnione jest podejmowanie wysiłków w poszukiwaniu możliwości wdrożenia adaptacyjnej techniki napromieniania pacjentów z nowotworem pęcherza moczowego. Wdrożenie takiej techniki napromieniania wymaga opracowania szybkiej metody oceniania aktualnej objętości pęcherza moczowego oraz podjęciu decyzji co do zastosowania planu leczenia $\mathrm{z}$ marginesem dopasowanym do stopnia wypełnienia pęcherza moczowego.

EP-TT-083: Weryfikacja stabilności wydajności akceleratorów medycznych za pomocą urządzenia QuickCheck firmy PTW

Patrycja Borowska ${ }^{1}$, Urszula Sobocka-Kurdyk ${ }^{1}$, Bartosz Pawałowski ${ }^{2}$

(1) Wielkopolskie Centrum Onkologii, Zakład Radioterapii III w Kaliszu, Kalisz, Polska

(2) Wielkopolskie Centrum Onkologii, Zakład Fizyki Medycznej, Poznań, Polska

WPROWADZENIE: Celem pracy było wdrożenie urządzenia QuickCheck do codziennej kontroli jakości akceleratorów medycznych. Podczas pracy zweryfikowano przydatność urządzenia pod kątem codziennej kontroli stabilności wydajności akceleratorów medycznych. Dodatkowo zbadano stałość współczynnika 
przejścia woda-fantom wrazz oceną wpływu efektu narastania dawki na stabilnośćniniejszego współczynnika. MATERIAŁ I METODA: Obowiązujące przepisy narzucają konieczność codziennej kontroli wydajności akceleratorów medycznych. Pomiaru można dokonać z wykorzystaniem komory jonizacyjnej umieszczonej w fantomie stałym lub wodnym oraz za pomocą dedykowanego urządzenia, np. QuickCheck. Sprawdzenia dokonuje się na podstawie pomiaru dawki, zmierzonej wbudowaną w urządzenie komorą jonizacyjną, umieszczoną w osi wiązki, zgodnie z zaleceniami producenta.

Dla umożliwienia porównywania wyników uzyskanych na podstawie pomiarów przy użyciu urządzenia QuickCheck z pomiarami referencyjnymi wykonanymi w wodzie wyznaczono współczynnik przejścia woda-fantom. Ze względu na zaobserwowaną zmienność współczynnika przejścia, dokonano kontroli jego stabilności na podstawie pomiarów wykonanych zgodnie z zaleceniami producenta oraz z zastosowaniem dodatkowego materiału absorbującego w postaci $3 \mathrm{~cm}$ PMMA.

WYNIKI: Spójność wartości wydajności akceleratora oszacowanej na podstawie pomiarów urządzeniem QuickCheck z wydajnością wyznaczoną na podstawie pomiarów w fantomie wodnym zbadano testem korelacji liniowej Pearsona. Uzyskane współczynniki korelacji wynoszą odpowiednio:

o $\quad$ Clinac 2300, energia X $6 \mathrm{MV}: \mathrm{r}=0,7673$

o $\quad$ Clinac 2300, energia X 20 MV: $\mathrm{r}=0,7214$

o TrueBeam, energia X $6 \mathrm{MV}: \mathrm{r}=0,7623$

o $\quad$ TrueBeam, energia X 15 MV: $r=0,7432$

Zmienność wyznaczonych współczynników przejścia woda-fantom zawiera się w granicach +/-1\%, nie zaobserwowano wpływu dodatkowego materiału rozpraszającego na stabilność powyższych współczynników WNIOSKI: Wysoka wartość wyznaczonych współczynników korelacji wskazuje, że urządzenie QuickCheck może być stosowane do codziennej kontroli stabilności wydajności akceleratorów medycznych.

Dobrą praktyką jest zastosowanie uśrednionych wartości współczynników przejścia, wyznaczonych na podstawie kilkukrotnych pomiarów, co pozwala wyeliminować błędy związane z pozycjonowaniem urządzenia.

Zastosowanie niepoprawnie wyznaczonego współczynnika przejścia nie ma wpływu na korelację pomiędzy wydajnością akceleratora obliczoną na podstawie pomiarów wykonanych w warunkach referencyjnych, a wydajnością oszacowaną w oparciu o pomiary urządzeniem QuickCheck, jedynie na stopień pokrycia się krzywych zmienności wydajności.

Nie odnotowano wpływu zastosowania dodatkowego build-up’u na stabilność wyznaczanego współczynnika przejścia, można więc zaniechać tej praktyki.

EP-TT-084:Fantomdotestówgeometrycznychkonwencjonalnychsymulatorówterapeutycznych oraz medycznych akceleratorów liniowych wraz z wyposażeniem dodatkowym Damian Kabat ${ }^{1}$, Monika Tomaszuk ${ }^{1}$, Radosław Kycia ${ }^{2}$, Zbigniew Latała ${ }^{2}$, Zbisław Tabor ${ }^{2}$

(1) Centrum Onkologii, Instytut im. Marii Skłodowskiej-Curie, Oddział w Krakowie, Kraków, Polska

(2) Instytut Teleinformatyki, Politechnika Krakowska, Kraków, Polska

WPROWADZENIE: Prezentacja założeń projektu fantomu wraz $\mathrm{z}$ dedykowanym systemem informatycznym, który umożliwia określenie parametrów geometrii medycznych akceleratorów liniowych oraz konwencjonalnych symulatorów terapeutycznych.

MATERIAŁ I METODA: Zostaną przedstawione podstawowe założenia projektu poprzez zdefiniowanie problemu optymalizacyjnego, którego rozwiązanie prowadzi do ustalenia w pierwszej kolejności położenia izocentrum promieniowania urządzenia terapeutycznego w globalnym układzie odniesienia $\mathrm{w}$ oparciu jedynie o obrazowanie 2D za pomocą portalu (EPID - electronic portal imaging device) fantomu o specjalnie zaprojektowanej geometrii, bez przyjmowania jakichkolwiek dodatkowych założeń na temat geometrii testowanego urządzenia terapeutycznego czy wyposażenia dodatkowego. Wychodząc od tej informacji, zostanie przedstawiona możliwość analitycznego wyznaczenia pozycji w przestrzeni pozostałych elementów urządzenia medycznego, wytypowanych do sprawdzenia w zakresie testów eksploatacyjnych, na podstawie tychże obrazów 2D, np. położenie stołu terapeutycznego, rotacja ramienia i kolimatora.

WYNIKI: Zostaną przedyskutowane możliwości analitycznego rozwiązania zdefiniowanego problemu 
optymalizacyjnego. Zostaną przedstawione wyniki przeprowadzonych symulacji pracy urządzeń radioterapeutycznych.

WNIOSKI: Fantom, który powstanie w wyniku realizacji projektu, będzie oparty na innowacyjnej koncepcji prowadzenia testów eksploatacyjnych w radioterapii, będącej wynikiem przedstawionych badań podstawowych. Opracowana koncepcja fantomu pozwala na całkowitą rezygnację z założeń leżących u podstaw testu Winstona-Lutza.

[Projekt finansowany jako projekt aplikacyjny w ramach Programu Operacyjny Inteligentny Rozwój 20142020 (numer wniosku o dofinansowanie: POIR.04.01.04-00-0014/16)].

\section{EP-TT-085: Czy możliwe jest zwiększenie efektywności protokołu NAL przy zachowaniu nakładu pracy? \\ Marta Giżyńska',2, Paweł Kukołowicz' ${ }^{1}$, Ben Heijmen ${ }^{3}$}

(1) Centrum Onkologii-Instytut im. Marii Skłodowskiej-Curie w Warszawie, Polska

(2) Uniwersytet Warszawski, Wydziat Fizyki, Zakład Fizyki Biomedycznej, Polska

(3) Eramus MC Cancer Institute, Rotterdam, Holandia

WPROWADZENIE: Planując radioterapię definiujemy margines CTV-PTV. Zwykle używany jest w tym celu wzór van Herka, który zapewnia dawkę minimalną w CTV równą 95\% u 90\% pacjentów. Boer i Heijmen zaproponowali protokół No-Action-Level (NAL) z rekomendowaną liczbą $\mathrm{N}=3$ frakcji napromienianych z wykonaniem zdjęć sprawdzających, po których jest obliczana korekcja położenia uwzględniana podczas dalszego leczenia. Bortfled pokazał, że korzystniej jest używać N=4. Protokół NAL skutkuje zmniejszeniem błędów systematycznych a w konsekwencji również zmniejszeniem rozmiaru marginesu. Celem tej pracy było zbadanie czy można tak zmodyfikować protokół NAL by zagwarantować jego większą efektywność przy podobnym nakładzie pracy.

MATERIAŁ I METODA: Celem przeprowadzenia badania protokołów NAL i zmodyfikowanego fNAL wykonano symulacje błędów ułożenia dla pacjentów pochodzących z różnych populacji: $\Sigma=\{1,2,3,4\}[\mathrm{mm}]$; $\sigma=\{1,2,3,4,5,6\}[\mathrm{mm}] ;$ std_r $=\{0.5,1,1.5,2\}[\mathrm{mm}]$. Gdzie $\Sigma$ określa błąd systematyczny populacji, $\sigma$ błąd przypadkowy populacji o rozrzucie równym std_r. Dla każdego zestawu $\Sigma$, $\sigma$, stdr generowano błędy ułożenia w 25 frakcjach dla wszystkich pacjentów (grupa 'all') i dla tych pacjentów dla których odchylenie standardowe błędu było duże (tj. mieściło się w górnych 2.5\% rozkładu normalnego - grupa 'large’). Następnie symulowano działanie protokołu NAL, CA i fNAL. W protokole NAL nie robiono żadnej korekcji do frakcji $\mathrm{N}$ a następnie wszystkie pozostałe frakcje były z korektą. W protokole CA od frakcji 3 do $\mathrm{N}$ wykonywano korektę na podstawie średniego błędu, przy czym zmieniała się liczba frakcji brana do obliczeń. W protokole fNAL od frakcji 4 sprawdzano czy błąd średniej jest mniejszy od pewnej wartości granicznej, jeśli nie, kontynuowano wykonywanie zdjęć portalowych stosując korektę tymczasową jak w CA, jeśli tak - obliczano korektę ostateczną.

WYNIKI: Porównując wyniki dla średnio 4 frakcji z obrazowaniem obserwujemy, że dla $\sigma=\{1,2\}[\mathrm{mm}]$ niezależnie od std_r margines dla błędów systematycznych jest niemal identyczny dla wszystkich trzech protokołów. Dla $\sigma>2 \mathrm{~mm}$ margines dla protokołu fNAL jest większy od marginesu dla pozostałych protokołów przy czym różnica ta jest poniżej $1 \mathrm{~mm}$. Jednocześnie rośnie o 10 - 20 punktów procentowych, procent pacjentów z grupy 'large’, dla których położenie CTV znajdowało się wewnątrz określonego marginesu.

WNIOSKI: Protokół fNAL pozwala zwiększyć efektywność protokołu NAL poprzez wychwycenie pacjentów, u których jest większy błąd przypadkowy.

\section{EP-TT-086: Promieniotwórczość wtórna tkanek po terapii hadronowej}

Przemysław Sękowski ${ }^{1}$, Izabela Skwira-Chalot ${ }^{1}$

(1) Wydział Fizyki Uniwersytet Warszawski, Warszawa, Polska

WPROWADZENIE: Hadronoterapia jest obiecującą metodą leczenia zmian nowotworowych pozwalającą na obniżenie dawki deponowanej w narządach krytycznych przy jednoczesnym zachowaniu docelowej 
dawki w obszarze terapeutycznym. W przeciwieństwie do terapii konwencjonalnej podczas leczenia wiązką hadronów wytwarza się wiele pierwiastków. Celem pracy jest oszacowanie i pomiar powstałej na skutek napromieniania radioaktywności wtórnej oraz próba estymacji jej wpływu na efekt terapeutyczny.

MATERIAŁ I METODA: W celu oszacowania liczby powstających pierwiastków wykorzystano narzędzie do symulacji Monte Carlo Geant4 z nakładką GATE. Pozwoli to na ilościową analizę spektrum powstałych pierwiastków wtórnych w wyniku napromieniania tkanki. Równocześnie oprogramowanie to pozwoli na zbadanie czy powstałe izotopy promieniotwórcze mogą mieć wpływ na całkowitą dawkę, jaką otrzymuje pacjent.

WYNIKI: Analiza teoretyczna pokazała, że istnieje zależność pomiędzy składem tkanki, rodzajem jonu oraz jego energią, a spektrum wytworzonych pierwiastków po napromienianiu. Głównymi pierwiastkami składowymi tego spektrum, dla wiązki protonów o energii $60 \mathrm{MeV}$, są O-15, C-11, Be-7 oraz N-13. Według obliczeń modelowych pierwiastki wtórne poprzez rozpady promieniotwórcze deponują w tkance o,2 mGy.

WNIOSKI: Wynikiteoretycznewskazują, żedla wykorzystanejwiązki, produktywtórnenajprawdopodobniej nie powodują zmiany efektu terapeutycznego. W celu ich weryfikacji konieczne jest przeprowadzenie eksperymentu. Doświadczenie, w którym zamrożona próbka wątroby wieprzowej zostanie napromieniona wiązką protonową o energii $60 \mathrm{MeV}$ będzie przeprowadzone w maju br. w Instytucie Fizyki Jądrowej PAN w Krakowie.

Wydaje się, że dla wyższych energii rola wtórnego promieniowania może znacząco wzrosnąć, dlatego też należy przeprowadzić analizę teoretyczną jak i eksperyment wykorzystujące bardziej energetyczne wiązki.

\section{EP-TT-087: Odtwarzanie i przekazywanie jednostki dawki pochłoniętej w wodzie z wykorzystaniem kalorymetru grafitowego \\ Piotr Tulik ${ }^{1}$, Adrian B. Knyziak², Agnieszka Paszcza' ${ }^{2}$, Michał Derlaciński², Ewa Kaczorowska²}

(1) Instytut Metrologii i Inżynierii Biomedycznej, Wydział Mechatroniki, Politechnika Warszawska, Warszawa, Polska

(2) Samodzielne Laboratorium Promieniowania Jonizującego, Główny Urząd Miar, Warszawa, Polska

WPROWADZENIE: W ramach współpracy Głównego Urzędu Miar z Instytutem Metrologii i Inżynierii Biomedycznej Wydziału Mechatroniki Politechniki Warszawskiej opracowano i wykonano kalorymetr grafitowy. Opracowany kalorymetr posłuży do budowy stanowiska wzorca pierwotnego dawki pochłoniętej w wodzie w Samodzielnym Laboratorium Promieniowania Jonizującego Głównego Urzędu Miar.

MATERIAŁ I METODA: Rdzeń opracowanego kalorymetru ma kształt walca o średnicy 23,5 mm i wysokości $5 \mathrm{~mm}$. Umieszczono w nim 4 termistory o rezystancji równej $33 \mathrm{k} \Omega$ dla $25^{\circ} \mathrm{C}$ w obudowie szklanej. Zadaniem tych termistorów jest pomiar przyrostu temperatury w funkcji dawki pochłoniętej w rdzeniu kalorymetru. Rdzeń wraz z termistorami umieszczony został w dwóch osłonach. Grubość ścian pierwszej i drugiej osłony równa jest $1 \mathrm{~mm}$. Odległości między poszczególnymi elementami kalorymetru wynoszą $1 \mathrm{~mm}$. Kalorymetr umieszczony jest na łożu pozycjonującym wewnątrz szczelnego fantomu wykonanego z PMMA. Szybkozłączka umieszczona w górnej pokrywie fantomu umożliwia wypompowywanie powietrza z fantomu do wartości -0,9 bar. Dodatkowo w pokrywie zamontowano uszczelnione złącza elektryczne niskoszumne, przez które wyprowadzone zostały połączenia termistorów. Termistory podłączane są do mostka Wheastone’a za pomocą kabla ekranowanego. Rdzeń kalorymetru oraz osłony wykonane są z ultra czystego grafitu o gęstości $1,81 \mathrm{~g} / \mathrm{cm} 3$.

WYNIKI: Opracowany kalorymetr umieszczony w fantomie wodnym umożliwia pomiar dawki pochłoniętej w wodzie w zakresie energetycznym od $150 \mathrm{keV}$ i w zakresie pomiarowym od o,2 Gy. Zmierzona dawka pochłonięta w graficie przeliczana jest na dawkę pochłoniętą w wodzie za pomocą współczynników konwersji zależnych od energii promieniowania. Współczynniki te wyznaczono za pomocą symulacji Monte Carlo. Niepewność odtworzenia dawki pochłoniętej w wodzie wynosi o,8\% przy k=2.

WNIOSKI: Przygotowano projekt i wykonano prototyp kalorymetru grafitowego. Opracowano procedurę pomiarową dawki pochłoniętej $\mathrm{w}$ graficie $\mathrm{z}$ wykorzystaniem zbudowanego kalorymetru, procedurę pomiarową przejścia $\mathrm{z}$ dawki pochłoniętej w graficie do dawki pochłoniętej w wodzie z wykorzystaniem symulacji Monte Carlo oraz wykazano eksperymentalnie poprawności działania kalorymetru. 


\section{EP-TT-088: Kardiotoksyczność radioterapii u pacjentek po chirurgicznym leczeniu oszczędzającym piersi lewej \\ Magdalena Peszyńska-Piorun ${ }^{1}$, Anna Papis-Ubych ${ }^{1}$, Bartosz Tomasik ${ }^{1}$, Michał Spych ${ }^{1}$, Adam Kluska ${ }^{1}$ \\ (1) Wojewódzkie Wielospecjalistyczne Centrum Onkologii i Traumatologii im. M. Kopernika w Łodzi, Polska}

WPROWADZENIE: Toksyczność kardiologiczna jest najczęstszą przyczyną zgonów chorych wyleczonych z raka piersi. W erze radioterapii planowanej trójwymiarowo ważne i możliwe jest oszacowanie dawek nie tylko w sercu, ale także w naczyniach wieńcowych czy jamach serca, a w przyszłości oszacowanie dawek tolerancji. Celem pracy było zakonturowanie wybranych struktur serca według atlasu kardiologiczego Mary Feng oraz RTOG, oszacowanie średnich dawek i odpowiedzenie na pytanie, czy istnieją zależności pomiędzy dawka średnią na serce a dawką na pozostałe zakonturowane struktury.

Analizę zaplanowano w równolicznych grupach chorych poddanych tomografii bez kontrastu oraz z podaniem środka kontrastującego, tak aby ocenić czy warunki badania mają wpływ na siłę i kierunek korelacji.

MATERIAŁ I METODA: U 10 pacjentek planowanie wykonano przy użyciu TK z kontrastem, u 10 zastosowano badanie bez kontrastu. Według atlasu kardiologicznego Mary Feng i RTOG doświadczony lekarz radioterapeuta zakonturował serce, lewą komorę - LV, lewą przednią tętnicę zstępującą - LAD, prawą tętnice wieńcową - RCA oraz obszary anterior myocardial territory - AMT i anterior myocardium - AMC. U wszystkich pacjentek wykonano konformalne, tangencjalne plany leczenia. Dawki porównano korelacją rang Spearmana, za istotne statystycznie przyjęto $\mathrm{p}<0,05$.

WYNIKI: Wśród pacjentek, u których wykonano TK z kontrastem, wykazaliśmy obecność silnych korelacji pomiędzy dawką średnią w LAD, LV i RCA, a dawką średnią w sercu, AMT i AMC (dla wszystkich powyższych $r>0,4, p<0,05)$. W przypadku pacjentek, u których przy badaniu nie podano kontrastu, dawki na LAD i LV były skorelowane z dawkami na serce, AMT i AMC, a w przypadku RCA korelacji nie wykazano.

WNIOSKI: Wykazano, że istnieje silna dodatnia korelacja pomiędzy średnią dawką na LAD, LV i RCA z dawką na serce, AMT i AMC. Nasze wyniki sugerują, że w przypadku badania bez kontrastu, które jest standardem $\mathrm{w}$ planowaniu radioterapii u chorych leczonych $\mathrm{z}$ powodu raka piersi, mogą występować trudności z zakonturowaniem naczyń wieńcowych, szczególnie mniejszych od LAD.

\section{EP-TT-089: Akcelerator do Radioterapii Śródoperacyjnej - wyniki prac projektu Inta-Dose} Agnieszka Misiarz ${ }^{1}$, Janusz Pracz ${ }^{1}$, Marta Kruszyna²

(1) Narodowe Centrum Badań Jądrowych, Świerk, Polska

(2) Wielkopolskie Centrum Onkologii, Poznań, Polska

WPROWADZENIE: Celem projektu było opracowanie innowacyjnego, kompleksowego Systemu do Radioterapii Śródoperacyjnej, zapewniającego łatwość pozycjonowania urządzenia i przygotowania go do pracy. System składa się z mobilnego akceleratora o zakresie energetycznym 4-12 MeV wraz z towarzyszącymi mu układami elektronicznymi i systemami informatycznymi.

Celem opracowania jest przedstawienie wyników pomiarów dozymetrycznych akceleratora śródoperacyjnego powstałego w wyniku projektu Intra-Dose.

MATERIAŁ I METODA: Akcelerator śródoperacyjny jest urządzeniem mobilnym. Akcelerator jest zbudowany na ruchomej podstawie zapewniającej przemieszczania głowicy aparatu.

Pomiary dozymetryczne względnego rozkładu dawki wykonano w fantomie wodnym PTW-P (PTW Freiburg). Krzywe głębokościowe (PDD) i profile pól promieniowania wykonano za pomocą diod typu E (PTW Freiburg). Analiza profili i krzywych spadku dawki wykonano za pomocą programu MEPHYSTO mcc (PTW Freiburg v. 1.8.0). Pomiary bezwzględne dawki wykonano za pomocą komory jonizacyjnej płasko równoległościennej typu Markus (PTW Freiburg).

Ustawiono parametry pracy dla energii 4; 6; 8; 10; 9; $12 \mathrm{MeV}$. Z pomiarów PDD została odczytana jakość wiązek (głębokość izodozy 80\%) dla poszczególnych energii.

Pomiar profili wiązki wykonano na głębokości referencyjnej zgodnie z normą IEC60976 - R8o/2, jak również na głębokości dawki maksymalnej. Pomiary wykonano dla aplikatorów $\Phi 10$ i $\Phi 5 \mathrm{~cm}$. SSD pomiaru to $60 \mathrm{~cm}$. Symetria pól promieniowania była obliczana ze wzoru $s=((\mathrm{D}(\mathrm{x})) /(\mathrm{D}(-\mathrm{x}))) \max \cdot 100 \%$, natomiast dewiacja 
w płaskości profilu jako Dmax-Dmin wyrażona w procentach dawki maksymalnej. Obliczenia wykonano zgodnie z normą IEC60976.

Przeprowadzono również pomiary powtarzalności i stabilności jednodniowej dawki zgodnie z IEC60976.

Zmierzono równieżliniowość odpowiedzi akceleratora - zależność dawki zadanej do zmierzonej zewnętrznym detektorem zgodnie z IEC60976.

WYNIKI: Jakość wiązek dla poszczególnych energii to: 12,32; 20,65; 27,94; 30,53; 34,81; 39,61 mm.

Symetria na obu głębokościach, dla wszystkich energii i dla obu aplikatorów nie przekroczyła 102\%

Dewiacja rozkładu płaskości profili dla obu głębokości, dla aplikatora $\Phi 5 \mathrm{~cm}$ nie przekroczyła $3 \%$, a dla aplikatora $\Phi 10 \mathrm{~cm} 6 \%$.

Powtarzalność dawki nie przekroczyła 0,5\%, a stabilność jednodniowa nie przekroczyła 3\%.

Liniowość odpowiedzi w zakresie od 10 do 2000 MU nie przekracza 2\% dla wszystkich energii.

WNIOSKI: Struktura akceleracyjna umożliwia osiągnięcie wiązki elektronów o energii z przedziału 4-12 $\mathrm{MeV}$ w dowolnej konfiguracji;

Układ akceleracyjny zapewnia stabilną wiązkę elektronów. Dla każdej energii, dla której zostały ustalone parametry pracy, uzyskano dwa poziomy mocy dawek 1000 i $500 \mathrm{cGy} / \mathrm{min}$.

Akcelerator śródoperacyjny powstały w projekcie jest prototypem urządzenia, które może zostać poddane procesowi uzyskania znaku CE.

\section{EP-TT-090: Analiza wyników weryfikacji jednostek monitorowych Andrzej Dąbrowski ${ }^{1,2}$, Daniel Kozłowski ${ }^{2}$, Piotr Pedrycz ${ }^{2}$ \\ (1) Instytut Fizyki, Uniwersytet Jana Kochanowskiego, Kielce, Polska \\ (2) Zakład Fizyki Medycznej, Świętokrzyskie Centrum Onkologii, Kielce, Polska}

WPROWADZENIE: W dzisiejszej radioterapii realizacja leczenia promieniowaniem jonizującym odbywa się na podstawie przygotowanych planów leczenia wykonanych przy użyciu systemów do planowania leczenia (Treatment Planing Systems TPS). Jednym z najważniejszych parametrów leczenia jest aplikowana dawka, która jest determinowana przez jednostki monitorowe obliczane w TPS. Jednym z ważnych elementów kontroli jakości w radioterapii jest niezależne od TPS obliczenie jednostek monitorowych w celu wyeliminowania potencjalnych błędów przed rozpoczęciem leczenia. W pracy przedstawiono wyniki analizy różnic pomiędzy jednostkami monitorowymi obliczonymi przez TPS oraz niezależny systemem. Różnice te porównywano z odpowiednim poziomem reagowania. Podjęto próbę odpowiedzi, czy istnieją różnice w weryfikacji jednostek monitorowych, które przekraczają przyjęty poziom reagowania, a jeśli tak to jakie są tego przyczyny.

MATERIAŁ I METODA: W Świętokrzyskim Centrum Onkologii jednostki monitorowe są obliczane przy użyciu systemu planowania leczenia Pinnacle. Do weryfikacji jednostek monitorowych użyto niezależnego systemu DIAMOND. System ten został zweryfikowany przed użyciem klinicznym. Analizę wykonano dla 806 pól terapeutycznych dla 190 pacjentów. Analizowani pacjenci byli napromieniani z powodu nowotworów ginekologicznych, piersi, płuc i prostaty. Poddano analizie 364 pola dla 81 pacjentów napromienianych z powodu nowotworów ginekologicznych, 200 pól dla 54 pacjentek napromienianych z powodu nowotworu piersi, 84 pól dla 19 pacjentów napromienianych z powodu nowotworu płuc oraz 158 pól dla 36 pacjentów napromienianych z powodu nowotworu prostaty. Obliczono różnice pomiędzy jednostkami monitorowymi obliczonymi przez TPS i system Diamond. Różnice te porównano z poziomem reagowania wynoszącym 3,5\%. WYNIKI: Dla 806 pól terapeutycznych 190 pacjentów uzyskano średnią różnicę pomiędzy jednostkami monitorowymi obliczonymi przez TPS a system Diamond wynoszącą 0,33\% oraz odchylenie standardowe 1,77\%. Dla pacjentów napromienianych z powodu nowotworów ginekologicznych różnica wyniosła 1,39\% a odchylenie standardowe $0,92 \%$, dla pacjentów napromienianych z powodu nowotworu piersi różnica wyniosła $-1,97 \%$ a odchylenie standardowe $0,9 \%$, dla pacjentów napromienianych z powodu nowotworu płuc różnica wyniosła -0,8\% a odchylenie standardowe $1,35 \%$, dla pacjentów napromienianych z powodu nowotworu prostaty $1,41 \%$ a odchylenie standardowe $0,97 \%$. Poziom reagowania nie został przekroczony dla żadnego pacjenta.

WNIOSKI: Analiza wyników kontroli jednostek monitorowych wykazała, że dla badanej grupy pacjentów 
różnice pomiędzy obliczonymi jednostkami monitorowymi przez TPS a niezależny system Diamond nie przekroczyły poziomu reagowania.

EP-TT-091:Ocenanieinwazyjnegosystemupozycjonowaniaokanaradioterapięstereotaktyczną nowotworów oczodołu napromienianych na aparacie CyberKnife

Agnieszka Skrobała ${ }^{1,2}$, Marta Adamczyk ${ }^{2}$, Agata Jodda², Joanna Litoborska², Joanna Dura ${ }^{3}$, Elżbieta Czajka $^{3}$, Piotr Janiga ${ }^{3}$, Piotr Milecki ${ }^{1,3}$

(1) Katedra i Zakład Elektroradiologii, Uniwersytet Medyczny Poznań, Polska

(2) Zakład Fizyki Medycznej, Wielkopolskie Centrum Onkologii, Poznań, Polska

(3) Zakład Radioterapii I, Wielkopolskie Centrum Onkologii, Poznań, Polska

WPROWADZENIE: Celem pracy była ocena użyteczności nieinwazyjnego systemu pozycjonowania oka na podstawie parametrów planu leczenia radioterapii stereotaktycznej (SRT) na aparacie CyberKnife (CK) u pacjentów z guzem w oczodole. Plany leczenia pacjentów z nowotworem oczodołu poddanych SRT na CK są często wyzwaniem ze względu na bliskość aparatu optycznego, a także ze względu na brak obiektywnych kryteriów ustalenia, czy osiągnięto optymalny plan leczenia.

MATERIAŁ I METODA: W celu oceny użyteczności nieinwazyjnego systemu pozycjonowania oka 16 pacjentów napromieniono od 1 do 14 frakcji z medianą 5 frakcji. Objętość PTV wynosiła od o,73-37,59cm3. Dawka zadana na izodozą 80\% mieściła się w zakresie od 20-50Gy z medianą 50Gy. System pozycjonowania oka był wykonany z polimeru i składał się z dwóch ramion: pionowego i poziomego, jego pionową część mocowano do podstawki unieruchamiającej głowę pacjenta za pomocą maski, a poziomą część umieszczono nad chorym okiem pacjenta (rycina 1). Pacjent patrzył na czarną kropkę umieszczoną na poziomym ramieniu systemu. Wyznaczenie odpowiedniej, stałej pozycji oka podczas tomografii komputerowej, a także całego procesu napromieniania było możliwe dzięki łatwej regulacji i możliwości zmiany ułożenia systemu zgodnie z możliwościami i potrzebami poszczególnych pacjentów.

WYNIKI: Nieinwazyjny system pozycjonowania oka był dobrze tolerowany przez wszystkich pacjentów i uzyskano stabilne i powtarzalne położenie oka. System może być używany podczas planowania i leczenia bez ingerencji z wiązkami terapeutycznymi, dawki dla systemu pozycjonowania wahały się od o,03-3,71Gy (mediana 1,14Gy, średnia 1,47Gy $\pm 1,23 \mathrm{SD}$ ). Czas napromienia pacjentów wynosił od 20-40min (mediana 29min, średnia 29min $\pm 5 \mathrm{SD}$ ) i był to typowy czas napromieniania guzów wewnątrzczaszkowych na CK. Pokrycie PTV $\geq 95 \%$ wynosiło od 92,99-99,05\% (mediana 95,86\%, średnia 96,41\% \pm 1,79 SD). Dawka w naprzeciwległym nerwie optycznym mieściła się od o,10-8,70Gy (mediana 4,04Gy, średnia 4,31Gy $\pm 2,47$ SD).

WNIOSKI: Wyniki tej pracy i dobre wyniki kliniczne wykazały użyteczność nieinwazyjnego systemu pozycjonowania oka w SRT na CK i potwierdziły brak konieczności implementacji znaczników wewnętrznych. SRT na CK wydaje się być stosunkowo bezpieczną techniką w leczeniu nowotworów oczodołu wewnątrz lub w pobliżu aparatu optycznego. SRT na CK przy użyciu systemu pozycjonowania oka zapewnia stałą i powtarzalną pozycję oka z jednoczesnym doskonałym pokryciem PTV bez dostarczania nadmiernej dawki do narządów krytycznych.

EP-TT-093: Zastosowanie druku 3D w radioterapii na przykładzie bolusa dedykowanego dla pacjenta z nowotworem głowy i szyi

Edyta Dąbrowska ${ }^{1,2}$, Anna Zawadzka ${ }^{1}$, Tomasz Zawistowski³, Tomasz Ciach ${ }^{4}$, Paweł Kukołowicz ${ }^{1}$

(1) Zakład Fizyki Medycznej, Centrum Onkologii-Instytut im. Marii Skłodowskiej-Curie, Warszawa, Polska

(2) Zakład Fizyki Biomedycznej, Uniwersytet Warszawski, Warszawa, Polska

(3) Centrum Badań Kosmicznych PAN, Warszawa, Polska

(4) Zakład Biotechnologii i Inżynierii Bioprocesowej, Politechnika Warszawska, Warszawa, Polska

WPROWADZENIE: Technologia druku 3D umożliwia potencjalnie lepszą dokładność dopasowania bolusa do anatomii pacjenta, co może znacznie wpłynąć na napromienienie pełną dawką terapeutyczną guzów 
naciekających skórę lub tkanki podskórne. Celem niniejszej pracy było porównanie dawki na powierzchni fantomu obliczonej przez system planowania leczenia i zmierzonej filmami Gafchromic. Ponadto na podstawie obrazowania CT poddano ocenie przyleganie drukowanych bolusów do powierzchni fantomu.

MATERIAŁ I METODA: W celu wykonania niniejszej pracy zeskanowano fantom antropomorficzny głowy i szyi, a następnie w systemie planowania leczenia Eclipse (v.13.6, Varian Medical Systems) wygenerowano bolus w obszarze krtani. Na podstawie pliku DICOM skonwertowanego do formatu STL zostały wydrukowane trzy bolusy: wypełniony strukturą plastra miodu (A), pusty (B) oraz wypełniony żelatyną (C). Bolusy zostały wydrukowane w technologii FDM (Fused Deposition Modeling) z polimeru PLA (PolyLactic Acid). Następnie na skanach CT wykonanych dla każdego bolusa, przygotowano pole otwarte z kąta głowicy $\mathrm{O}^{\circ}$ oraz plan leczenia techniką IMRT, którymi trzykrotnie napromieniono fantom $\mathrm{z}$ odpowiednim bolusem. Ponadto fantom z bolusem A i B został napromieniony planem leczenia IMRT przygotowanym dla bolusa C. Dawki na powierzchni fantomu zostały zmierzone filmami Gafchromic EBT3 (Radiation Products Design Inc.). $\mathrm{Z}$ systemu planowanie leczenia odczytano obliczone na powierzchni fantomu dawki, a także sprawdzono jednostki Hounsfielda (HU) wydrukowanych bolusów.

WYNIKI: Wramach niniejszej pracy porównano dawki zmierzonena powierzchnifantomu zwykorzystaniem dozymetrii filmowej z dawkami odczytanymi z systemu planowania leczenia. Dla pola prostopadłego do powierzchni bolusa otrzymano różnice 3,7\%, 9,4\%, 4,0\%, odpowiednio dla bolusa A, B i C. W przypadku napromienienia fantomu planami leczenia przygotowanymi techniką IMRT otrzymano różnice: 1,6\%, 7,8\% i5,3\%. W wyniku napromienia bolusa A i B planem leczenia IMRT dla bolusa Cotrzymano różnice odpowiednio 4,3\%, 4,4\%. Pomimo wykonania zindywidualizowanych bolusów 3D na skanach CT zaobserwowano obszary odstawania bolusa od powierzchni fantomu, co może być spowodowane jakością wykorzystanego do badania fantomu. Analiza jednostek HU wykazała, że tylko dla bolusa C gęstość elektronowa jest zbliżona do gęstości tkanek miękkich (HU = -47.79). Dla bolusa A i B jednostki HU wynoszą odpowiednio -594.58 oraz -807,81. WNIOSKI: Na podstawie wstępnych wyników pracy można stwierdzić, iż każdy z wydrukowanych bolusów umożliwia przygotowanie akceptowalnego planu leczenia, jednakże tylko bolus C ma jednostki HU zbliżone do tkanek miękkich. Pomimo zindywidualizowanego procesu przygotowania bolusa zauważono obszary odstawania bolusa od powierzchni fantomu. Otrzymane wyniki stanowią podstawę do dalszej pracy.

\section{EP-TT-094: Wyniki zewnętrznego audytu dozymetrycznego TLD w radioterapii w 2016 roku Wioletta Ślusarczyk-Kacprzyk ${ }^{1}$, Wojciech Bulski ${ }^{1}$, Piotr Ulkowski ${ }^{1}$, Krzysztof Chełmiński ${ }^{1}$ \\ (1) Zakład Fizyki Medycznej, Centrum Onkologii, Warszawa, Polska}

WPROWADZENIE: Rozporządzenie Ministra Zdrowia z dnia 18 lutego 2011 r. w Rozdziale 8 mówi o zewnętrznych audytach dozymetrycznych. Prawodawca nakazuje coroczne przeprowadzenie takiego audytu w każdym ośrodku prowadzącym teleradioterapię. Pierwszy pilotażowy audyt dozymetryczny SSDL w Centrum Onkologii-Instytut w Warszawie organizowało w 1991 roku.

MATERIAŁ I METODA: W 2016 roku do audytu przystąpiło 35 ośrodków radioterapetycznych. Audytowi poddano łącznie 124 wiązek, w tym 91 wiązki promieniowania X oraz 33 wiązek elektronów w warunkach referencyjnych i niereferencyjnych. Uczestnicy audytu otrzymali detektory TLD (po 3 na jedną audytowaną wiązkę), które napromienili dawką 2Gy. Na podstawie danych ze stosowanego systemu planowania leczenia określano liczbę jednostek monitorowych potrzebną do napromienienia detektorów TL zadaną dawką. Po napromienieniu kapsułek mierzona była moc dawki kontrolowanej wiązki i obliczana dawka, jaką otrzymałaby kapsułka, dla liczby jednostek monitorowych podanych przez system planowania leczenia. Następnie uczestnicy audytu odsyłali detektory do SSDL. W tym samym czasie (w oknie pomiarowym) w SSDL, w wiązce Co-6o napromieniane są detektory referencyjne. Użytym detektorem był proszek LiF typu MT-F wyprodukowane przez IFJ PAN w Krakowie. Napromieniane są znaną dawką, więc sygnał z ich odczytu jest wartością odniesienia do obliczenia rzeczywistej dawki z detektorów nadesłanych przez uczestnika. Do odczytu proszku użyto czytnika PCL 3 firmy Fimel. Miarą poprawności uzyskiwanych wyników jest delta: delta $=100 *(\mathrm{Dd}-\mathrm{DSSDL}$, śr $) / \mathrm{DSSDL}$, śr [\%]

gdzie: Dd - dawka deklarowana przez uczestnika, DSSDL,śr - średnia dawka z odczytów wykonanych w SSDL Przyjęto trzy poziomy odchyleń dawki uczestnika audytu dla warunków referencyjnych: 
delta $<= \pm 3,5 \%$ - wyniki są poprawne

$3,5 \%<\mid$ delta $\mid<=5,0 \%$ - wyniki wymagają wyjaśnienia,

delta $> \pm 5,0 \%$ - wyniki wymagają wyjaśnienia, a następnie konieczne jest powtórzenie pomiarów.

WYNIKI: W większości ośrodków wyniki były prawidłowe. Wartość delty powyżej 3,5\% stwierdzono dla 8 wiązek w 7 ośrodkach. W przypadku dwóch wiązek promieniowania X oraz jednej wiązki elektronów wynik zawierał się w granicach 3,5\% - $5 \%$. Dla 3 wiązek promieniowania X, oraz 2 wiązek elektronowych delta przekroczyła wartość 5,0 \% (od 6,5\% do 125\%). We wszystkich siedmiu ośrodkach wyjaśniono przyczyny uzyskania negatywnych wyników, a powtórny audyt dał wyniki pozytywne.

WNIOSKI: Zewnętrzne audyty dozymetryczne stanowią ważne narzędzie zapewnienia jakości leczenia i bezpieczeństwa pacjentów poddawanych taleradioterapii w ośrodkach onkologicznych w Polsce.

\section{EP-TT-095: Kiedy korekcja manualna zwiększa dokładność rejestracji obrazu podczas pozycjonowania pacjentów z rakiem prostaty?}

Tomasz Piotrowski ${ }^{1,2}$, Agata Jodda ${ }^{2}$, Iwona Goncarzewicz ${ }^{1}$, Bartosz Bąk ${ }^{1,3}$, Krzysztof Kaczmarek ${ }^{3}$

(1) Katedra i Zakład Elektroradiologii, Uniwersytet Medyczny, Poznań, Polska

(2) Zakład Fizyki Medycznej, Wielkopolskie Centrum Onkologii, Poznań, Polska

(3) Zakład Radioterapii 2, Wielkopolskie Centrum Onkologii, Poznań, Polska

WPROWADZENIE: Podczas pozycjonowania, całkowite przesunięcie ciała pacjenta w którejkolwiek z osi jest sumą przesunięć uzyskanych w wyniku korekcji automatycznej (program komputerowy) i manualnej, zależnej od subiektywnej oceny obserwatora.

Celem badania było określenie progu dla korekcji manualnej, powyżej którego, uwzględnienie jej w sposób istotny wpływa na całkowite przesunięcie ciała pacjenta podczas radioterapii raka stercza.

MATERIAŁ I METODA: W badaniu wykorzystano dane obrazowe 60 pacjentów z rakiem stercza leczonych na aparacie tomoterapeutycznym w latach 2012-2015. Codzienne obrazowanie MVCT obejmowało obszar tarczowy (prostata lub prostata wraz z pęcherzykami nasiennymi) powiększony w osi długiej o $10 \mathrm{~mm}$ z każdej strony. Każde dzienne MVCT zostało nałożone na obrazy z planowania leczenia (kVCT) pięciokrotnie, przez pięciu niezależnych obserwatorów. Uzyskane w ten sposób dane dotyczące przesunięć automatycznych i manualnych poddano analizie. W oparciu o uzyskane dane określono: (1) wartości przesunięć całkowitych, (2) korelację pomiędzy przesunięciami automatycznymi i manualnymi, (3 i 4) współczynniki zmienności i asymetrii dla przesunięć manualnych.

WYNIKI: (1) Zarówno dla każdego z obserwatorów jak i dla każdej z osi ponad 75\% przesunięć całkowitych mieści się w przedziale od zera do 4 milimetrów.

(2) Wraz ze wzrostem przesunięć automatycznych wzrastają przesunięcia manualne (oś: poprzeczna, $\mathrm{R}=0.913$; pionowa, $\mathrm{R}=0.991$ oraz strzałkowa, $\mathrm{R}=0.739$ ).

(3) Wraz z maleniem wartości przesunięcia manualnego wzrasta współczynnik zmienności (wzrastają rozbieżności pomiędzy wartościami przesunięć manualnych wyznaczanymi przez różnych obserwatorów). Małą zmiennością obarczone są przesunięcia manualne większe niż $1 \mathrm{~mm}$.

(4) Zbiory przesunięć manualnych zebrane przez pięciu niezależnych obserwatorów dla których uśredniona wartość była mniejsza niż $1 \mathrm{~mm}$ nie cechowały się żadnym dominującym zwrotem.

WNIOSKI: Korekcja manualna w sposób istotny wpływa na całkowite przesunięcie ciała pacjenta gdy jej wartość bezwzględna jest większa niż $1 \mathrm{~mm}$. Mniejsze wartości korekcji manualnej mieszczą się w wartości błędu subiektywnej ocenyobserwatora inie powinnybyćuwzględnianepodczas pozycjonowania ciała pacjenta. Wartości korekcji manualnej ściśle korelują z wartościami korekcji automatycznej. Jednomilimetrowej korekcji manualnej odpowiada dwumilimetrowa korekcja automatyczna. Dlatego też korekcja manualna powinna być uwzględniana gdy bezwzględne wartości korekcji automatycznej są większe od 2 mm.

EP-TT-096: Wpływ parametrów skanowania i rekonstrukcji na jednostki Hounsfiled'a na przykladzie systemu Philips Brilliance

Dominika Oborska-Kumaszyńska ${ }^{1}$ 
(1) The Royal Wolverhampton NHS Trust, MPCE Department, England

WPROWADZENIE: Celem projektu było dopuszczenie systemu TK (Philips Brilliance ver.4.2.0.17057) do użytku klinicznego w radioterapii. Częścią projektu było ustalenie wpływu parametrów skanowania i rekonstrukcji na wartości HU. Założeniem było, że powinny być stałe.

MATERIAŁ I METODA: Dla wszystkich zaimplementowanych protokołów klinicznych zbadano wpływ ACS, filtrów rekonstrukcyjnych (FR), rekonstrukcji iteracyjnej, OMAR, szerokości warstwy tomograficznej (SWT), eFOV na wartości HU. Rekonstrukcje wykonano dla fantomów: CATPHAN6oo, CIRS (z rozszerzonym zestawem materiałów-aluminium, tytan, stal), obiekty testowe Philips $(15 \mathrm{~cm}-50 \mathrm{~cm}$ srednicy). Poddano ocenie jakościowej i ilościowej parametry obrazów. Wyznaczono charakterystyki (gęstość masowa)=f(HU) dla 6 protokołów i z nich średnią. Porównano wyniki dla protokołów ze stałym mAs, ACS, z/bez OMAR, różnych położeń materiałów w CIRS.

WYNIKI: FR „enhanced” (korekcja:+/-1) vs standardowe filtry - zmiana HU +/-30HU/powietrze/teflon (CATPHAN). FRUB (mozgowie) vs FRB - zmiana HU -70HU/teflon (producent deklaruje, że FRUB może wpływać na HU), -6oHU/derlin, +30HU/powietrze (CATPHAN). Poziom rekonstrukcji iteracyjnej- nie wpływa na HU. SWT (1.5mm vs $0.75 \mathrm{~mm})$ - zmiana HU +20HU/teflon przy wezszej warstwie (CATPHAN). ACS- uzyskane wyniki wskazuja na niejednoznaczny, znaczący rozrzut wartości HU (zwłaszcza dla wysokiej gęstości materiałów) dla różnych protokołów, jak i w analizie dlugoterminowej. Wartości HU dla obiektów powyżej $40 \mathrm{~cm}$ średnicy są obciążone dużą niepewnością. Różnice HU dla różnych metod skanowania obiektu 50cm wynosily 50HU przy SD $\sim 40 H U$. Położenie materiału w CIRS - zmiana HU dla najgęstszych materiałów: 20HU/gęsta kość, 30HU/aluminium, 100HU/tytan, 500-70oHU/stal. eFOV- różnice HU vs wartości oczekiwane wynosiła $\sim 180-\sim 250 H U$. ACS vs stałe mAs - różnice HU dla gęstych materiałów przypadkowe i o dużej dyspersji ( -100HU-+230HU). OMAR - korekcja przybliżała wartości HU do wartości oczekiwanych.

WNIOSKI: Systemy TK w RT, sa dostarczane z modalnosciami, ktorych zysk zastosowania w diagnostyce nie budzi watpliwosci. Mogą mieć wpływ na wartości HU (podstawa do definiowania gęstości masowej/ elektronowej materiałów) i obliczaną dawkę w SPL. 100HU błędu w ocenie HU dla wody skutkuje $1.5 \%$ różnicy w obliczanej dawce na $5 \mathrm{~cm}$ dla $6 \mathrm{MV}$. Wszystkie elementy systemu/oprogramowania wpływające na wartości HU, a mające zastosowanie w protokolach kilicznych, musza byc poddane weryfikacji.

\section{EP-TT-097: Acuros XB 13.6 w zastosowaniu radioterapii stereotaktycznej płuc w oparciu o rekomendacje RTOG o813. Analiza przypadku \\ Tomasz Siudziński ${ }^{1}$, Marzena Janiszewska ${ }^{1}$}

(1) Zakład Fizyki Medycznej, Dolnośląskie Centrum Onkologii we Wrocławiu, Wrocław, Polska

WPROWADZENIE: Celem pracy jest analiza problemu w uzyskaniu rekomendowanych przez RTOG o813 rozkładów dawki w obrębie guza płuc, przy zastosowaniu nowego algorytmu Acuros XB 13.6, w szczególności zmian zlokalizowanych centralnie.

MATERIAŁ I METODA: W sekwencji 4D wykonano tomografię komputerową pacjenta. Do obliczeń użyto algorytmów Acuros XB 13.6, oraz odniesiono plany do AAA 13.6. Zastosowano energię 6FFF i 10FFF. Do oceny planu użyto histogramu dawki i liniowych rozkładów dawki.

WYNIKI: Plan w technice Rapid Arc przygotowano dla frakcjonowania stereotaktycznego 5x9 Gy, za pomocą algorytmu AAA 13.6. Plan znormalizowanego zgodnie z protokołem RTOG o813. Izodoza referencyjna została wybrana zgodnie RTOG 0813. Plan spełniał wymagania konformalności dawki w guzie. Po wykonaniu obliczeń algorytmem Acuros XB 13.6 uzyskano w porównaniu do AAA, następujące parametry:

Stosunek objętości izodozy ref do objętości PTV: 1,67 (Acuros); 1,21 (AAA); <1,2 (RTOG)

Stosunek objętości izodozy 50\% do objętości PTV: 7,84 (Acuros); 5,04 (AAA); <4,3 (RTOG)

Dawka maksymalna >2cm od PTV: 78,1\% (Acuros); 62,3\% (AAA); <58\% (RTOG)

Dodatkowo wykonano bezpośrednie przeliczenie realnych map fluencji uzyskanych w planowaniu przy pomocy AAA algorytmem Acuros. Uzyskano następujące porównanie:

DPTV(95\%)=35,1 Gy (Acuros); 45,o Gy (AAA) 
$\operatorname{DPTV}(99 \%)=32,0$ Gy (Acuros); 42,3 Gy (AAA)

$\operatorname{VPTV}(45 \mathrm{~Gy})=70,1 \%$ (Acuros); 95,0\% (AAA)

WNIOSKI: Używając nowoczesnych algorytmów (tj. Acuros XB) uzyskujemy większą niejednorodność rozkładu dawki w centralnie położonych obszarach płuca i nie jesteśmy w stanie spełnić wymagań protokołu RTOG 0813. Brak jest jak dotąd rekomendacji klinicznych stosowania, rozkładów dawek determinujących wysoką niejednorodność, podobnie jak po zastosowaniu do praktyki klinicznej algorytmów AAA, należy wspólnie z zespołem radioterapeutów przeanalizować wartość dawki frakcyjnej, oraz wartość normalizacyjnej izodozy.

\section{EP-TT-098: System nadzoru w dozymetrii \\ Maciej Raczkowski' ${ }^{1}$, Marzena Janiszewska ${ }^{1}$ \\ (1) Zakład Fizyki Medycznej, Dolnośląskie Centrum Onkologii we Wrocławiu, Wrocław, Polska}

WPROWADZENIE: Ogromna liczba informacji generowana podczas poszczególnych etapów przygotowania, planowania i realizacji radioterapii powoduje, iż nieodzownym elementem nowoczesnego systemu radioterapeutycznego stają się platformy nadzoru - zarządzania i weryfikacji. Platformy te pozwalają na gromadzenie, przetwarzanie oraz walidację poprawności danych wymienianych pomiędzy kluczowymi elementami systemu. Z tożsamą sytuacją mamy do czynienia w przypadku nowoczesnych systemów dozymetrycznych, gdzie liczba danych towarzysząca każdej czynności pomiarowej, w połączeniu z stosowaniem różnych systemów dozymetrycznych, dostarczanych często przez różnych producentów, wymusza stosowanie zintegrowanych platform wymiany i archiwizacji danych.

MATERIAŁ I METODA: Z uwagi na złożoną strukturę organizacyjną Dolnośląskiego Centrum Onkologii, polegającą na lokacji 4 z 10 dostępnych akceleratorów w dwóch ośrodkach satelitarnych, podjęta została decyzja o wdrożeniu systemu nadzoru w obszarze dozymetrii, bazującej na rozwiązaniu dostarczonym przez firmę IBA. Zakup platformy myQA w zestawieniu z system kontroli codziennej StarTrack, w który wyposażono wszystkie akceleratory, pozwolił na zbudowanie systemy nadzoru z centralnym serwerem bazodanowym zlokalizowanym we Wrocławiu.

WYNIKI: Platforma myQA dzięki niezależnemu serwerowi, pozwala na gromadzenie, archiwizację oraz analizę statystyczną wszystkich danych pochodzących ze zintegrowanych w ramach platformy urządzeń i systemów pomiarowych. Szeroki zakres obsługiwanych systemów dozymetrycznych, fantomów oraz gotowych protokołów pomiarowych bazujących na zaleceniach i wytycznych organizacji międzynarodowych, w połączeniu z możliwości rozbudowy o własne urządzenia, fantomy i testy sprawia, iż platforma myQA może być pomocnym narzędziem w nadzorze dla złożonych struktur organizacyjnych.

WNIOSKI: Mocnymi punktami platformy nadzoru myQA, są w przypadku złożonych struktur organizacyjnych, możliwościzlecaniai egzekwowania testów dla różnych grupzawodowych,odpowiedzialnych za sprawdzenie odpowiednich parametrów zgodnie z zakresem obowiązków. Automatyczny zapis wyników przeprowadzonych testów na macierzy dyskowej, daje możliwość wglądu w wyniki, ich powtórnej obróbki oraz analizy statystycznej, w ramach dostępu domenowego, również dla innych istniejących struktur sieciowych np. systemu zarządzania i weryfikacji w radioterapii. Analiza trendów czasowych dostępna poprzez przeglądarkę internetową z każdego komputera w obrębie zdefiniowanej domeny, pozwala na podejmowanie decyzji o przeprowadzeniu regulacji danego parametru lub podjęciu interwencji serwisowej z dużym wyprzedzeniem. Systemy nadzoru w dozymetrii podobnie jak systemy zarzadzania i weryfikacji w radioterapii są nieuniknione, biorąc pod uwagę dynamiczny rozwój nowych technologii w tym obszarze.

\section{EP-TT-099: Weryfikacja dozymetryczna dawki obliczonej przez system planowania leczenia pod bolusem}

Agnieszka Walewska ${ }^{1}$, Agata Latała ${ }^{1}$, Edyta Dąbrowska ${ }^{1,2}$, Anna Zawadzka ${ }^{1}$

(1) Zakład Fizyki Medycznej, Centrum Onkologii Instytut im.Marii Skłodowskiej-Curie w Warszawie, Warszawa, Polska

(2) Zakład Fizyki Biomedycznej, Wydział Fizyki, Uniwersytet Warszawski, Warszawa, Polska 
WPROWADZENIE: Bolusy są stosowane w radioterapii jako proste modyfikatory rozkładu dawki. Celem pracy była ocena dokładności obliczeń systemu planowania leczenia w obszarze narastania dawki. Porównano dawkę obliczoną przez system planowania leczenia (Eclipse v.13.6, AAA v.13.6, Varian) pod bolusem i zmierzoną z użyciem filmów Gafchromic EBT3 (Radiation Products Design Inc.) dla różnych głębokości w fantomie, wielkości pól oraz rodzajów i grubości bolusów.

MATERIAŁ I METODA: W pracy wykorzystano trzy rodzaje bolusów: bolus żelowy (MacroMedics) oraz dwa rodzaje bolusów termoplastycznych (Orfit): płachtowy i płachtowy przygotowywany przez użytkownika z granulatu. Wykonano CT fantomu z bolusami o grubościach $0.5 \mathrm{~cm}$ i $1.0 \mathrm{~cm}$. W oparciu o otrzymywane skany obliczono rozkład dawki dla dwóch rodzajów pól: statycznego o wymiarach 10 x $10 \mathrm{~cm}$ (dawka 80.2 cGy w izocentrum bez bolusa) i dynamicznego (sliding window) formowanego przez szparę mlc o szerokości $1.0 \mathrm{~cm}$ (dawka 87.1 cGy w izocentrum bez polusa). Wykonano pomiar dawki filmami Gafchromic EBT3 w fantomie stałym na głębokości $1 \mathrm{~mm}$ i $5 \mathrm{~mm}$. Detektory filmowe umieszczone byłe prostopadle do osi centralnej wiązki (kąt ramienia aparatu oo). Odległość do płaszczyzny, na której znajdowały się detektory filmowe była stała i wynosiła odpowiednio: $90.1 \mathrm{~cm}$ i $90.5 \mathrm{~cm}$. Pomiary wykonano z wykorzystaniem wiązki wysokoenergetycznych fotonów o energii nominalnej 6MV generowanej przez akcelerator TrueBeam 2.5 (Varian). Niepewność pomiaru wynosiła 2\%(1SD).

WYNIKI: Dla bolusów o grubości $1 \mathrm{~cm}$ różnica w dawce obliczonej przez system planowania leczenia wyniosła od: $-3.4 \%$ do $3.7 \%$ co odpowiada różnicy w dawce maksymalnie $4.7 c G y$ na frakcję. Dla bolusów o grubości $0.5 \mathrm{~cm}$ różnica w dawce obliczonej przez system planowania leczenia wyniosła od: $-13.4 \%$ do 10.5\% co odpowiada różnicy w dawce maksymalnie $17.8 \mathrm{cGy}$ na frakcję. Większe różnice otrzymano dla pól z bolusem $0.5 \mathrm{~cm}$ oraz dla pola dynamicznego. Nie ma znaczących różnic w zgodności wyników dla bolusów żelowych i termoplastycznych.

WNIOSKI: Wyniki pomiarów dawki dla obu rodzajów bolusów termoplastycznych, niezależnie od grubości bolusa i głębokości pomiaru mieszczą się w granicach błędu pomiarowego. Dalsza analiza dokładności obliczeń dawki w obszarze narastania powinna być rozszerzona o pomiar płaską komora jonizacyjną z uwzględnieniem poprawki Gerbi'ego.

\section{EP-TT-100: Sprawdzenie poprawności automatycznej analizy parametrów kontroli jakości systemów obrazowania używanych do weryfikacji teleradioterapii (IGRT) na przykładzie programu ARTISCAN \\ Paulina Porwot ${ }^{1}$}

(1) Centrum Radioterapii Amethyst, Kraków, Polska

WPROWADZENIE: Celem pracy jest sprawdzenie dokładności i powtarzalności automatycznej analizy obrazów wykorzystywanych w kontroli jakości systemów obrazowania oraz porównanie wyników między akceleratorami.

MATERIAŁ I METODA: W okresie od kwietnia 2015 r. do lutego 2017 r. przeprowadzono pomiary na akceleratorach liniowych Elekta Synergy. Na trzech sprawdzano system obrazowania megawoltowego z wykorzystaniem fantomu EPID_QC, a na dwóch dodatkowo system obrazowania kilowoltowego z wykorzystaniem fantomów TOR_18FG oraz CATPHAN_503.

Analizę obrazów prowadzono w programie ARTISCAN, służącym do automatycznego obliczania i oceny parametrów obrazu. Przeprowadzono dedykowane do poszczególnych fantomów testy zaimplementowane w programie.

Na podstawie uzyskanych danych wykonano ocenę powtarzalności testów, porównanie i analizę statystyczną. WYNIKI: Powtarzalnymi testami dla poszczególnych fantomów, w których nie ma istotnej statystycznie różnicy między akceleratorami są:

jednorodność, liniowość przestrzenna, odległość, zniekształcenie obrazu, poprzeczny rozkład sygnału dla EPID_QC;

jasność-kontrast, zniekształcenie geometryczne, rozdzielczość niskokontrastowa dla TOR_18FG; jednorodność,zniekształceniegeometryczne,kontrast,rozdzielczośćwysokokontrastowadlaCATPHAN_503. Istotne różnice statystyczne zauważono w testach: liniowość sygnału, rozdzielczość niskokontrastowa, 
rozdzielczość wysokokontrastowa dla EPID_QC; rozdzielczość przestrzenna dla TOR_18FG.

Testy dla CATPHAN_503: pozycja warstwy, grubość warstwy, przyrost warstwy, rozdzielczość przestrzenna są obliczane z niedokładnie zlokalizowanych ROI-ów.

Niepewność pomiaru wyznaczono z odchylenia standardowego średniej, uwzględniając współczynnik rozkładu t-Studenta oraz wykonano testy statystycznej istotności różnic (poziom istotności $\alpha=0,05$ ).

WNIOSKI: Program ARTISCAN usprawnia pracę, jednakże powinien oferować narzędzia do manualnej korekty położenia ROI-ów oraz możliwości śledzenia algorytmu obliczeniowego.

Dokładność automatycznego pozycjonowania obrazów i dopasowania ROI-ów do badanych obiektów ma duże znaczenie $\mathrm{w}$ próbie określenia wartości parametrów. Jednak w ARTISCANIE nie jest to realizowane w sposób powtarzalny. W testach, dla których ROI-e są niewielkich rozmiarów lub gęsto ułożone występują niedokładności ich umiejscowienia, wpływające na rozrzut wyników.

W naszej ocenie, z powodu jakości obrazów tomograficznych uzyskiwanych z paneli EPID, testy dla CATPHAN_5O3 nie dostarczają miarodajnych wyników, aby wyznaczać wartości odniesienia. Fantom ten dedykowany jest do kontroli tomografu.

Najczęstszym artefaktem pojawiającym się na obrazach z paneli EPID w naszym ośrodku jest segmentacja obrazu. Testem pozwalającym najlepiej przedstawić ten problem w sposób ilościowy jest jednorodność obrazu.

Na różnicę wartości parametrów między akceleratorami mógł wpłynąć różny stopień degradacji paneli EPID w czasie.

\section{EP-TT-101: Wpływ modulatora energii na rozkład dawki w radioterapii z użyciem wiązki protonowej \\ Magdalena Garbacz ${ }^{1}$, Izabela Skwira-Chalot ${ }^{1}$}

(1) Wydziat Fizyki, Uniwersytet Warszawski, Warszawa, Polska

WPROWADZENIE: Znalezienie optymalnych parametrów modulatora (tj. jego grubość i kształt) w celu uzyskania najkorzystniejszego rozkładu dawki w zmianie nowotworowej. Odpowiednie umiejscowienie depozycji energii wiązki, co przedkłada się na dawkę deponowaną, za pomocą modulatora ma duży wpływ na efektywność leczenia. Pozwala to także zwiększyć bezpieczeństwo pacjenta przez ograniczenie dawki w tkankach zdrowych.

MATERIAŁ I METODA: Ogólnodostępne oprogramowania GATE (Geant4 Application for Tomographic Emission) daje możliwość przeprowadzenia symulacji opartych na algorytmie Monte Carlo i uzyskać rozkłady dawki deponowanej przez wiązkę protonową w zadanym ośrodku. Obliczenia rozpoczęto od napromienienia fantomu wodnego i porównano otrzymany rozkład $\mathrm{z}$ danymi eksperymentalnymi. Kolejne symulacje przeprowadzono dla hipotetycznego przypadku nowotworu wątroby stosując różne geometrie modulatorów w celu uzyskania odpowiedniego rozkładu dawki w zmianie nowotworowej.

WYNIKI: Analiza rozkładów dawki w funkcji zasięgu dla trzech różnych geometrii modulatorów pozwoliła wyznaczyć optymalną prędkość modulatora podczas napromieniania oraz dopasować jego grubość do wielkości hipotetycznej zmiany nowotworowej.

WNIOSKI: Mając informacje o wielkości i lokalizacji zmiany nowotworowej można stworzyć układ doświadczalny w oprogramowaniu GATE, a następnie zasymulować napromienianie wiązką protonową. Duża zgodność z danymi eksperymentalnymi wskazuje na wiarygodność użytego oprogramowania. Stosując symulacje komputerowe można poszukiwać optymalnych rozwiązań do polepszenia jakości elementów stosowanych w protonoterapii.

\section{EP-TT-102: Kontrola parametrów dynamicznych kolimatora Agility Magdalena Tumidajewicz ${ }^{1}$ \\ (1) Centrum Radioterapii Amethyst, Kraków, Polska}

WPROWADZENIE: Porównanie wyników i próba wyznaczenia wartości oczekiwanych dla testów 
kolimatora Elekta Agility.

MATERIAŁ I METODA: Prowadzono kontrole parametrów kolimatora Agility na trzech akceleratorach Elekta Synergy w okresie od 2014r do 2017r z wykorzystaniem panela EPID jako detektora oraz programu ARTISCAN do automatycznej analizy obrazu. Kontrola obejmowała testy statyczne oraz dynamiczne zdefiniowane w programie ARTISCAN i dedykowane do kontroli parametrów kolimatora wielolistkowego. W testach statycznych wyznaczono korekcje(m.in. środek obrazu i rotacja kolimatora), niezbędne do przeprowadzenia analizy testów dynamicznych. Testy dynamiczne to: dMLC; Static/VMAT_Picket_Fence i VMAT_Picket_Fence with errors, Dose_Rate/Gantry_Speed; MLC_Speed.

WYNIKI: W teście dMLC analizowano tory ruchu par listków i dla każdego z nich obliczano średnią wartość liczby zliczeń, która ma reprezentować prędkość poruszania się listków. Porównywano prędkości poszczególnych par listków, poruszających się ze stałą prędkością do średniej prędkości dla wszystkich par (średnie odchylenie 0.15\%). W testach Static/VMAT_Picket_Fence zaobserwowano odchylenia od oczekiwanych pozycji nie przekraczające $1 \mathrm{~mm}$ w izocentrum, a w skrajnych obszarach średnio 3 pary listków z zakresu od 1mm do $1.5 \mathrm{~mm}$. Nie zaobserwowano odchyleń większych niż 2mm. W teście DoseRate/ GantrySpeed największe odchylenia, wynoszące 1.5\% w porównaniu do referencyjnego pola otwartego wystąpiły dla ROI ze skrajnymi wartościami mocy dawki i prędkości gantry. W teście MLC_Speed największe odchylenia, wynoszące 4\% względem referencyjnego pola otwartego wystąpiły w obszarach, w których napromienianie zrealizowano z najmniejszą prędkością listków i najniższą mocą dawki. Porównując wyniki między akceleratorami nie stwierdzono różnic istotnych statystycznie.

WNIOSKI: Test dMLC okazał się być czuły (szczególnie brzeżne pary listków) na korekcje położenia obrazu. Zdarzają się listki o odchyleniach rzędu 3-4\% co może być spowodowane nie tylko różnicą prędkości, ale również niepoprawnym dopasowaniem toru. W testach Static/VMAT_Picket_Fence wraz z oddalaniem się listków od izocentrum obserwujemy symetryczny wzrost odchyleń od pozycji oczekiwanych. Ustalono wartość tolerancji równą $1 \mathrm{~mm}$.

W testach DoseRate/GantrySpeed oraz MLCSpeed największe odchylenia w stosunku do referencyjnego pola otwartego wystąpiły dla skrajnych wartości prędkości ruchu gantry/listków oraz niskiej mocy dawki (20-25MU/min). Jeśli rozpatrywać tylko przedziały mocy dawki i prędkości, w których realizowana jest większość planów terapeutycznych, uśrednione różnice wynoszą odpowiednio 1,1\% oraz 1,5\%. Poddano również ocenie przydatność oprogramowania do automatycznej analizy obrazów. Zaletą jest usprawnienie analizy oraz prezentacja wyników w sposób ilościowy oraz analiza trendu. Wadą jest niepoprawne rozpoznawanie obiektów w skrajnych obszarach obrazu, oraz brak możliwości wyboru danych poddawanych analizie i ich manualnej korekcji.

\section{EP-TT-103: Teleradioterapia a narażenie kobiety w ciąży}

Agnieszka Kuchcińska ${ }^{1}$

(1) SZEDAR Laboratorium Badawcze, Polska

WPROWADZENIE: Celem pracy jest analiza przypadków wykonywania teleradioterapii pacjentek w ciąży oraz ich narażenia i uzasadnienia wykonania procedury teleradioterpii z uwzględnieniem możliwych skutków stochastycznych oraz deterministycznych dla płodu

MATERIAŁ I METODA: W ramach materiału badawczego analizowano raporty, dokumenty oraz materiały szkoleniowe: Międzynarodowej Komisji ds. Ochrony Radiologicznej (ICRP), Międzynarodowej Agencji Energii Atomowej (IAEA), oraz materiały prezentowane Pierwszego Europejskiego Kongresu Fizyki Medycznej (ECMP 2016) w Atenach. Analizowano raportowane poziomy dawek na płód dla wybranych procedur z teleradioterapii versus kryteria narażenia płodu (skutki deterministyczne i stochastyczne) w zależności od dawki promieniowania. Badano uzasadnienie (lub jego brak) dla odpowiednich procedur teleradioterapii

WYNIKI: Raporty ICRP podają, że dawki dla płodu poniżej 10omGy nie powinny być przyczyną rozważania aborcji natomiast dawki poniżej 10mGy związane są z bardzo ograniczonym ryzykiem dla płodu. Zespół dr Any Rity Figueiry z CENTRO HOSPITALAR SAO JOAO, Poro, Portugalia, przedstawił wykonaną procedurę optymalizacji planu leczenia oraz wyniki wykonanej analizy oszacowania dawek oraz ryzyka dla płodu 
podczas sesji teleradioterpii oponiaka. Wykonane pomiary komorą jonizacyjną przy zastosowaniu fantomu antropomorficznego, płyt PMMA wykazały, że estymowana dawka dla płodu to 2,5 cGy < 10 cGy dawki bezpiecznej raportowanej przez ICRP. Podczas napromieniowywania pacjentki dwka została walidowana i potwierdzona poprzez pomiary przy zastosowaniu detektorów TLD. Raportowano pozytywny przebieg sesji teleradioterpii oraz fakt, że ciąża przebiegała normalnie, a pacjentka urodziła zdrowe dziecko

WNIOSKI: Procedury teleradioterpia narządów takich jak np. głowa mogą być związane z dawkami sumarycznymi dla płodu znacznie poniżej poziomów określonych przez ICRP jako bezpieczne dla płodu. Dawki dla płodu powinny być oszacowane podczas wykonywania i weryfikacji planu leczenia a następnie potwierdzane i mierzone podczas sesji napromieniania. Odpowiednio zaplanowane i nadzorowane procedury teleradioterpii narządów oddalonych od płodu mogą wiązać się z bezpiecznym leczeniem pacjentki oraz zachowaniem bezpieczeństwa radiologicznego płodu tj. dawki sumarycznej poniżej 100mGy, w takich przypadkach radiowarażliwość płodu nie powinno być przeciwwskazaniem dla leczenia teleradioteraputycznego

\section{EP-TT-104: Wpływ zastosowanej metody napromieniania raka piersi na wielkość obszaru niskich dawek (eIORT vs. 3D-CRT)}

Sławomir Nowakowski ${ }^{1}$, Agnieszka Orzechowska ${ }^{1}$, Janusz Winiecki ${ }^{1}$, Sebatian Maleszka ${ }^{1}$

(1) Zakład Fizyki Medycznej, Centrum Onkologii w Bydgoszczy, Polska

WPROWADZENIE: Powszechnie stosowaną metodą leczenia raka piersi jest leczenie oszczędzające BCT Breast Conserving Treatment. Wyniki leczenia poprawia uzupełnienie terapii o radioterapię na cały gruczoł piersiowy a dostarczenie dodatkowej dawki promieniowania na okolicę loży po guzie -tzw." boost”, w sposób znaczący zmniejsza ryzyko miejscowej wznowy.

W naszym ośrodku procedurę napromieniania boostu wykonujemy techniką śródoperacyjną z wykorzystaniem wysokoenergetycznych elektronów (eIORT) generowanych przez mobilny akcelerator Mobetron oraz w ramach teleradioterapii z użyciem wiązek fotonowych generowanych przez akceleratory Clinac firmy Varian.

Celem pracy jest porównanie obszarów objętych niskimi dawkami w przypadku zastosowania wymienionych metod do napromienienia loży po guzie.

MATERIAŁ I METODA: Analiza objęła 10 pacjentek leczonych w Centrum Onkologii w Bydgoszczy. Wyznaczono i przeanalizowano objętości tkanek odpowiadających izodozom obejmującym: 10\%, 20\%, 30\% oraz 50\% dawki terapeutycznej przy zastosowaniu obu metod.

W przypadku radioterapii śródoperacyjnej objętości niskich dawek oszacowano na podstawie danych dozymetrycznych użytych do obliczenia czasu napromieniania oraz przy uwzględnieniu warunków geometrycznych i anatomicznych podczas zabiegu.

Plany napromieniania wiązkami zewnętrznymi wykonano w systemie planowania leczenia Eclipse i wykorzystując jego możliwości wyznaczono objętości tkanek napromienianych niskimi dawkami.

WYNIKI: Zaobserwowano znaczące różnice w wielkości obszarów napromieniowanych niskimi dawkami pomiędzy zastosowanymi metodami

W przypadku radioterapii śródoperacyjnej wielkość obszaru niskich dawek w znikomym stopniu zależy od objętości napromienianej loży po guzie. Warto zwrócić uwagę na fakt, że tkanki prawidłowe odsuwane są poza obszar napromieniania i nie są eksponowane na promieniowanie.

W metodzie napromieniania wiązkami zewnętrznymi zasadniczy wpływ na objętości napromieniane niskimi dawkami ma wielkość gruczołu piersiowego oraz położenie loży po guzie w stosunku do całego gruczołu piersiowego.

WNIOSKI: Zastosowanie techniki śródoperacyjnej z wykorzystaniem wysokoenergetycznych elektronów (eIORT) ogranicza skażenie ciała pacjenta niskimi dawkami promieniowania jonizującego. 


\section{bez filtra spłaszczającego Agnieszka Walewska ${ }^{1}$}

(1) Zakład Fizyki Medycznej, Centrum Onkologï Instytut im.Marii Skłodowskiej-Curie w Warszawie, Warszawa, Polska

WPROWADZENIE: Ocena komory jonizacyjnej Semiflex 3D (PTW) o objętości czynnej o.07 cm3 jako detektora do pomiarów względnych w szerokim zakresie pól. Porównanie wyników uzyskanych komorą Semiflex 3D (PTW) z wynikami referencyjnymi, uzyskanymi komorą Semiflex (o.125 cc, PTW) dla pól z zakresu 20-40 cm oraz wynikami uzyskanymi detektorem microDiamond (SSCD, PTW) dla pól z zakresu $2-20 \mathrm{~cm}$.

MATERIAŁ I METODA: Wszystkie pomiary wykonano $\mathrm{w}$ technice izocentrycznej (SSD=90cm, d=10 $\mathrm{cm}$ ) w fantomie wodnym MP-3 (PTW). Wykonano pomiary profili, procentowych dawek głębokich (PDG) i wydajności względnych komorą Semiflex 3D (PTW) w dwóch orientacjach: pionowej i poziomej dla pól z zakresu 2-40 cm. Analogiczne pomiary wykonano komorą Semiflex (0.125 cc, PTW) i detektorem microDiamond (SSCD, PTW). Detektorem referencyjnym dla pól 2-20 cm był SCDD, a dla pól z zakresu 20$40 \mathrm{~cm}$ komora jonizacyjna Semiflex (0,125 cc). Pomiary wykonano dla dwóch wiązek wysokoenergetycznego promieniowania X o energiach nominalnych 6MV i 6 FFF MV generowanych przez akcelerator TrueBeam (Varian). Pomiary wykonano dla pól: $2 \times 2 \mathrm{~cm}, 3 \times 3 \mathrm{~cm}, 4 \times 4 \mathrm{~cm}, 10 \times 10 \mathrm{~cm}, 20 \times 20 \mathrm{~cm}, 40 \times 40 \mathrm{~cm}$.

WYNIKI: Wyniki wydajności względnych uzyskane komorą Semiflex 3D (PTW) w obu orientacjach zgadzają się, poza obszarem narastania dawki, w granicach $0.5 \%$ z wynikami uzyskanymi detektorami referencyjnymi, poza polem $2 \times 2 \mathrm{~cm}$, dla którego różnica wynosi 1.6\% dla wiązek 6MV i 6FFF MV. Szerokości półcieni (dla obu typów wiązek FF i FFF użyto klasycznej definicji półcienia, chociaż nie ma ona zastosowania klinicznego w wiązkach bez filtra spłaszczającego) dla obu wiązek była do $2 \mathrm{~mm}$ większa dla komory Semiflex 3D vs microDiamond i porównywalna z komorą Semiflex. Zgodność PDG w całym zakresie testowanych pól, dla obu orientacji wynosiła 0.5 punktu procentowego.

WNIOSKI: Brak znaczących różnic w wynikach w zależności od orientacji komory Semiflex 3D. Wyniki pomiarów względnych dawki uzyskane komorą jonizacyjną Semiflex 3D charakteryzują się zadowalającą zgodnością z wynikami otrzymanymi detektorami referencyjnymi w zakresie wielkości pól zgodnych ze specyfikacją (>2.5 cm) dla wiązek $6 \mathrm{MV}$ i $6 \mathrm{FFF}$ MV, poza szerokością półcieni. Do pełnej oceny detektora niezbędna jest weryfikacja komory Semiflex 3D(PTW) jako detektora do pomiarów bezwzględnych dawki.

\section{Skawiński ${ }^{2}$ \\ (1) Katedra i Klinika Onkologii i Brachyterapii, Collegium Medicum w Bydgoszczy, UMK w Toruniu, Polska \\ (2) Zakład Fizyki Medycznej, Centrum Onkologii w Bydgoszczy, Polska}

EP-TT-106: Wpływ ułożenia rąk pacjenta na rozkład dawki u chorego leczonego metodą TBI Janusz Winiecki ${ }^{1,2}$, Karolina Majewska ${ }^{1,2}$, Agnieszka Orzechowska ${ }^{2}$, Sebastian Maleszka ${ }^{2}$, Tomasz

WPROWADZENIE: Celem badania było zaprojektowanie optymalnej pozycji terapeutycznej, która istotnie zredukowałaby niekorzystny efekt związany z redukcją dawki w kręgosłupie oraz tylnej części ściany klatki piersiowej na wysokości Th-L powodowany tłumieniem promieniowania przez ramię pacjenta.

MATERIAŁ I METODA: Przeanalizowano rozkłady dawki u wybranych 10 dorosłych pacjentów (lub o budowie ciała zbliżonej do dorosłej), którzy poddani zostali radioterapii TBI. Obliczenia wykonano przy użyciu TPS Eclipse dla pól bocznych: głowica 9ostopni, odległość SSD 400cm.

We wszystkich przypadkach potwierdzono niekorzystny efekt związany z obniżeniem dawki w obszarze kręgosłupa. U dwóch kolejnych pacjentów wykonano dodatkowo symulację dawki również w nowej, proponowanej pozycji terapeutycznej: ramiona uniesione, ułożone na klatce piersiowej tak by łokcie stykały się ze sobą, natomiast dłonie obejmujące szyję.

W trakcie napromieniania wykonane obliczenia zweryfikowano przy pomocy dozymetrii „in vivo”.

WYNIKI: Zaproponowane nowe ułożenie rąk w trakcie realizacji pól bocznych pozwoliło wyeliminować niekorzystny efekt polegający na redukcji dawki w kręgosłupie oraz żebrach po stronie tylnej. Zaobserwowano ponadto, iż ramiona ułożone na klatce piersiowej dostarczają dodatkowego rozproszenia powodując wzrost dawki w przedniej części ściany klatki piersiowej, eliminując ryzyko jej niedopromienienia. Dłonie obejmujące 
szyję powodują w efekcie przyrost masy tkankowej (wzrasta umowna szerokość tkanek na wysokości szyi), co może poprawić jednorodność rozkładu dawki na granicy obszarów ramiona-szyja, istotnie różniących się pod względem wymiarów geometrycznych.

WNIOSKI: Redukcja dawki w obszarze trzonów Th-L może zostać wyeliminowana poprzez proponowane ułożenie rąk na klatce piersiowej.

\section{EP-TT-107: Pierwsza w Polsce radioterapia protonowa metodą wiązki skanującej w Centrum Cyklotronowym Bronowice}

Renata Kopeće ${ }^{1}$, Tomasz Kajdrowicz ${ }^{1}$, Liliana Stolarczyk ${ }^{1}$, Konrad Guguła ${ }^{1}$, Paweł Olko

(1) Instytut Fizyki Jądrowej PAN, Kraków, Polska

WPROWADZENIE: Od listopada 2016 roku odbywa się w Centrum Cyklotronowym Bronowice IFJ PAN radioterapia protonowa na stanowiskach gantry.

MATERIAŁ I METODA: Pacjenci napromieniani są najnowocześniejszą metodą wiązki skanującej. Radioterapia protonowa odbywa się we współpracy z Centrum Onkologii Instytut oddział w Krakowie (COIOK), gdzie pacjenci są kwalifikowani do radioterapii protonowej. Kolejne etapy wykonywane są we współpracy przy udziale zespołów CCB IFJ PAN oraz COI-OK. Po wykonaniu unieruchomień, skanów tomograficznych oraz planów leczenia oraz pomyślnej weryfikacji dozymetrycznej możliwa jest resymulacja (na stanowisku gantry), a następnie rozpoczyna się proces napromieniania.

WYNIKI: Obecnie napromienianych jest dziennie ok 10 pacjentów z lokalizacjami zgodnymi ze wskazaniami Ministra Zdrowia na dwóch stanowiskach gantry.

WNIOSKI: Obecnie napromienianie zakończyło kilkudziesięciu pacjentów.

\section{EP-TT-108: Prosty model ilustrujący wynik pomiaru pola łukowego przy użyciu matrycy dozymetrycznej \\ Arkadiusz Kowalski ${ }^{1}$, Monika Weselak ${ }^{1}$ \\ (1) Szpital Specjalistyczny Podkarpacki Ośrodek Onkologiczny w Brzozowie, Brzozów, Polska}

WPROWADZENIE: (Bardziej pytania na które szukano odpowiedzi). Czy można w prosty sposób dokonać symulacji kształtu profilu poprzecznego rejestrowanego przez matrycę dozymetryczną podczas napromieniania tej matrycy polem prostokątnym podczas obrotu głowicy akceleratora wokół owej matrycy? Jak wyglądał będzie ów profil dla różnych szerokości pola promieniowania? Jak będzie wyglądał dla określonego zakresu kątów?

Czy można ową symulację wykorzystać i określić przy jej pomocy jakieś parametry geometrii akceleratora medycznego?

MATERIAŁ I METODA: Stworzono model symulujący kształt poprzeczny profilu rejestrowanego przez matrycę dozymetryczną umieszczoną na stole terapeutycznym podczas obrotu głowicy aparatu. Pole padające na matrycę jest wąskim polem prostokątnym. Jest to prosty model oparty na zaledwie trzech parametrach, są to: początkowe położenie głowicy aparatu, końcowe położenie głowicy aparatu oraz szerokość szczeliny. Model ów zostanie zaprezentowany.

Jednym z narzędzi przy pomocy którego dobierano parametry modelu oraz weryfikowano uzyskane za jego pomocą krzywe z krzywymi pomiarowymi jest własnoręcznie napisane oprogramowanie, które również zostanie przedstawione.

Krzywe uzyskane w wyniku symulacji numerycznej uwzględniającej ów model porównano ze zmierzonymi krzywymi.

WYNIKI: Przedstawione zostanie potencjalne zastosowanie modelu.

Wydaje się, że dzięki opracowanemu modelowi można określić szerokość pola promieniowania. Jednym z możliwych dodatkowych zastosowań matrycy dozymetrycznej może być określenie wielkości pola promieniowania. Zastosowanie to zweryfikowano przy pomocy pomiarów dozymetrycznych.

Opracowano test służący do pomiaru szerokości pola promieniowania. Przy pomocy testu zmierzono 
szerokość pola dla trzech różnych wartości ustawionych na konsoli aparatu. Uzyskane wyniki odniesiono do wartości rzeczywistych.

WNIOSKI: Możliwe jest dokonanie pomiaru szerokości pola promieniowania z dużą dokładnością pomimo, że rozdzielczość matrycy użytej do pomiaru wynosi $0,76 \mathrm{~cm}$.

\title{
Plakat elektroniczny: Diagnostyka Obrazowa [EP-DO]
}

\author{
w obrazowaniu zmian demielinizacyjnych $w$ przebiegu stwardnienia rozsianego \\ Patrycja Mazgaj ${ }^{1,2}$, Zofia Drzazga ${ }^{1,2}$, Aldona Giec-Lorenz ${ }^{3}$ \\ (1) Instytut Fizyki im. A. Chełkowskiego, Zakład Fizyki Medycznej, Uniwersytet Śląski, Katowice, Polska \\ (2) Śląskie Międzyuczelniane Centrum Edukacji i Badań Interdyscyplinarnych, Chorzów, Polska \\ (3) Helimed Diagnostic Imaging Sp. z o.o., Pracownia Rezonansu Magnetycznego, Katowice, Polska
}

EP-DO-109: Wartość diagnostyczna wybranych sekwencji rezonansu magnetycznego

WPROWADZENIE: Stwardnienie rozsiane (SM) to jedna z najbardziej powszechnych chorób demielinizacyjnych centralnego układu nerwowego, która stopniowo obniża poziom jakości życia pacjentów. Zgodnie z danymi przedstawionymi przez Europejską Platformę Stwardnienia Rozsianego (EMSP) w Polsce żyje co najmniej 45 tysięcy osób z zdiagnozowanym SM. Celem pracy jest więc oszacowanie wartości diagnostycznej wybranych sekwencji MRI stosowanych obecnie w diagnostyce SM w przypadku obrazowania zmian demielinizacyjnych zarówno w obszarze istoty białej jak i szarej mózgu.

MATERIAŁ I METODA: Badania przeprowadzono dla 25 kobiet w wieku $(38,5 \pm 8,5)$ lat z rozpoznaniem G35 (stwardnienie rozsiane) wg Międzynarodowej Statystycznej Klasyfikacji Chorób i Problemów Zdrowotnych ICD-10. Pomiary wykonano przy użyciu aparatu firmy Siemens w systemie MAGNETOM Aera 1.5T w ramach normalnej pracy klinicznej w Centrum Diagnostyki Obrazowej Helimed wykorzystując m.in. sekwencje FLAIR, DIR, mapy ADC. Pomiary intensywności sygnału zmian demielinizacyjnych w porównaniu z obszarami referencyjnymi dla wybranych lokalizacji przeprowadzono w programie Fiji (ImageJ).

WYNIKI: Wyliczone stosunki intensywności sygnałów zmian demielinizacyjnych do obszarów referencyjnych dla istoty białej i mieszanej przy pomocy sekwencji FLAIR i map ADC były wyraźnie różne i zawierały się w granicach 1,3-1,7 w zależności od badanych struktur. Dla istoty szarej najwyższe stosunki (2-5) obserwowano dla sekwencji DIR. Ponadto niektóre zmiany były również widoczne w sekwencji FLAIR, ale stosunki intensywności sygnału zmian do referencji były mniejsze od 1,3.

WNIOSKI: W przypadku istoty szarej wskazane jest obrazowanie wyspecjalizowaną sekwencją DIR podczas gdy istota biała i mieszana jest widoczna zarówno we FLAIR jak i mapach ADC w porównywalnej wartości diagnostycznej.

\section{EP-DO-110: Zastosowanie obrazowania termicznego do oceny efektów chirurgicznej dekompresji zespołu cieśni nadgarstka \\ Agnieszka Baic ${ }^{1}$, Armand Cholewka ${ }^{1}$, Michał Rżany², Beata Englisz ${ }^{1}$, Teresa Kasprzyk ${ }^{1}$, Agata Stanek³ Karolina Sieroń-Słotny ${ }^{4}$, Arkadiusz Granek², Krzysztof Suszyński5, Wiesław Marcol² \\ (1) Śląskie Międzyuczelniane Centrum Edukacji i Badań Interdyscyplinarnych, Uniwersytet Śląski, Chorzów, Polska \\ (2) Katedra i Zakład Fizjologii, Wydział Lekarski, Śląski Uniwersytet Medyczny, Katowice, Polska \\ (3) Katedra i Oddział Chorób Wewnętrznych, Angiologii i Medycyny Fizykalnej w Bytomiu, Śląski Uniwersytet w Katowicach, Polska \\ (4) Zakład Fizyki Medycznej, Śląski Uniwersytet Medyczny, Katowice, Polska \\ (5) Katedra Medycyny Sportowej i Fizjologii Wysiłku Fizycznego, Wydział Lekarski, Śląski Uniwersytet Medyczny, Katowice, Polska}

WPROWADZENIE: Celem przeprowadzonych badań było zweryfikowanie czy obrazowanie termiczne może zostać zastosowane w diagnostyce oraz ocenie efektów leczenia chirurgicznego zespołu cieśni nadgarstka. Dotychczasowe rozpoznanie tego rodzaju schorzenia jest dosyć trudne i opiera się głównie na wykonywaniu badań palpacyjnych w momencie pojawienia się objawów bólowych. Wykonanie obrazowania termicznego 
dłoni może pomóc w lepszym i szybszym diagnozowaniu tego zespołu chorobowego, umożliwiając pacjentom szybszy powrót do zdrowia.

MATERIAŁ I METODA: Badania termograficzne zostały przeprowadzone w grupie pacjentów przed operacją zdiagnozowanego zespołu cieśni nadgarstka oraz 4 tygodnie po operacji w tych samych warunkach pomiarowych. Grupa pacjentów składała się zarówno z kobiet,

jak i mężczyzn, w różnych przedziałach wiekowych. Za pomocą kamery termowizyjnej E6o FLIR Systems dokonano pomiarów temperatury wewnętrznej i zewnętrznej strony obu dłoni pacjentów. Dodatkowo w celu porównania wyników, wykonano badania na grupie kontrolnej - zdrowych ochotników w podobnym przedziale wiekowym.

WYNIKI: Otrzymane wyniki pokazały wysoki gradient temperatury między analizowanymi obszarami zainteresowania dłoni, co może świadczyć o tym, iż na skutek ucisku na nerwy przebiegające przez kanał nadgarstka dochodzi do zmian w ukrwieniu, a tym samym temperaturze powłok skórnych w rejonie zaopatrzenia przez nerw pośrodkowy u pacjentów. Z kolei badania wykonane 4 tygodnie po zabiegu operacyjnym wskazały na zmniejszenie gradientu temperaturowego między badanymi obszarami zainteresowania. Otrzymane wartości parametrów termicznych zbliżone były do otrzymanych dla grupy kontrolnej.

WNIOSKI: Przeprowadzone badania i ich analiza mogą świadczyć o przydatności obrazowanie termicznego w diagnostyce jak i ocenie efektów zespołu cieśni nadgarstka.

\section{EP-DO-111:Zastosowanietermografiiiplanimetrii wocenieefektówtlenoterapiihiperbarycznej w leczeniu owrzodzeń żylnych podudzi}

Beata Englisz ${ }^{1}$, Armand Cholewka ${ }^{1}$, Ewa Firganek ${ }^{1}$, Grzegorz Knefel ${ }^{2}$, Grzegorz Liszka ${ }^{1}$, Marek Kawecki², Mariusz Nowak ${ }^{2}$, Karolina Sieron-Stołtny ${ }^{3}$, Agata Stanek ${ }^{4}$

(1) Zakład Fizyki Medycznej, Instytut Fizyki im. A. Chełkowskiego, Uniwersytet Śląski, Katowice, Polska

(2) Centrum Leczenia Oparzeń im. dr Stanistawa Sakiela w Siemianowicach Śląskich, Polska

(3) Zakład Medycyny Fizykalnej Katedry Fizjoterapii, Wydziat Nauk o Zdrowiu w Katowicach, Śląski Uniwersytet Medyczny w Katowicach, Polska

(4) Katedra i Oddział Kliniczny Chorób Wewnętrznych, Angiologii i Medycyny Fizykalnej, Śląski Uniwersytet Medyczny w Katowicach, Polska

WPROWADZENIE: Celem pracy była ocena termiczna efektów leczenia owrzodzeń żylnych podudzi za pomocą tlenoterapii hiperbarycznej oraz próba korelacji parametrów termicznych z wynikami planimetrycznymi.

MATERIAŁ I METODA: Grupa badawcza stanowiła 25 pacjentów (11 kobiet i 14 mężczyzn) cierpiących na owrzodzenia żylne podudzi, w wieku $65 \pm 17$, leczonych za pomocą tlenoterapii hiperbarycznej. Pojedynczy zabieg w komorze hiperbarycznej trwał 86 minut. Każdy pacjent poddany był 30 zabiegom. Otrzymane wyniki analizowano zarówno uwzględniając pojedyncze sesje w komorze hiperbarycznej oceniając obrazy termiczne otrzymane przed i bezpośrednio po pojedynczej sesji tlenoterapii jak i biorąc pod rozważania pełny cykl leczenia grupując wyniki pacjentów w poszczególnych okresach trwania całego cyklu: pierwsza część leczenia (o-10 zabiegów) - okres I, druga część (10-20) - II oraz trzecia część leczenia (20-30) - okres III. WYNIKI: Przeprowadzone badania pokazały różnice w parametrach planimetrycznych oraz termicznych opisujących obszary zmienione chorobowo u większości pacjentów, co sugeruje wpływ tlenoterapii hiperbarycznej na procesy odbudowy krążenia włośniczkowego, zmniejszenie stanu zapalnego i uruchomienia procesów termoregulacji.

WNIOSKI: Na podstawie otrzymanych wyników wydaje się, iż zastosowanie diagnostyki termowizyjnej w przypadku owrzodzeń żylnych podudzi może dać istotne informacje nie tylko w ocenie efektów leczenia, ale być może w kwalifikacji pacjentów do tego typu terapii. Nasuwa się również wniosek, aby połączyć obie techniki obrazowania, aby jednocześnie lekarz miał możliwość oceny rany zarówno na poziomie strukturalnym jak i zasięgu intensywności procesów metabolicznych, gdyż obie techniki wydają się uzupełniać, co może nieść korzyści w procesie oceny stopnia rozwoju choroby. 


\section{EP-DO-112: Optymalizacja parametrów badania SPECT/CT scyntygrafii kośćca pod kątem narażenia pacjenta na promieniowanie jonizujące \\ Monika Tomaszuk ${ }^{1}$, Damian Kabat ${ }^{1}$, Anna Dziecichowicz ${ }^{1}$, Teresa Kowalska ${ }^{1}$}

(1) Centrum Onkologii Instytut im. Marii Skłodowskiej-Curie Oddział w Krakowie, Kraków, Polska

WPROWADZENIE: Celem pracy jest przedstawienie procesu optymalizacji parametrów badania CT pod kątem zmniejszenia narażenia pacjentów na promieniowanie jonizujące podczas badania SPECT/CT bez negatywnego wpływu na jakość uzyskiwanych obrazów SPECT po zastosowaniu korekcji osłabienia promieniowania (attenuation correction, AC) w przypadku badania scyntygraficznego kośćca.

MATERIAE I METODA: Badania przeprowadzono z użyciem urządzenia SPECT/CT typu AnyScan SC (Mediso) oraz fantomu Jaszczaka, gdzie standardowe „zimne“ źródła zastąpiono źródłami „gorącymi“ o średnicach od 10 do 40mm. Korpus fantomu wypełniono roztworem nadtechnecjanu sodu Na99mTcO4. „Gorące” źródła wypełniono roztworem wodnym wodorofosforanu di-potasu K2HPO4 wymieszanym z roztworem Na99mTcO4, symulując tkankę kostną gromadzącą radiofarmaceutyk. Zastosowanie takiej mieszaniny zapewnia pochłanianie promieniowania jonizującego jak w tkance kostnej [wg. de Dreuille O, Strijckmans V, Almeida P, Loc'h Ch, Bendriem B, et al. Bone equivalent liquid solution to assess accuracy of transmission measurments in SPECT and PET. IEEE Transactions on Nuclear Science. 1997;44(3):11861190]. Stosunek koncentracji aktywności w źródłach względem tła utrzymywano na poziomie 10:1. Fantom poddano wielokrotnym badaniom SPECT/CT dla różnych kombinacji wartości napięć oraz natężeń prądu badania CT (napięcia: 80-120kV, natężenia: 10-200mA). Badanie CT dla każdej analizowanej kombinacji parametrów użyto do korekcji AC badania SPECT. Wpływ badań CT uzyskanych dla różnych parametrów (za kombinację odniesienia przyjęto $120 \mathrm{kV}$ oraz 50mA) na jakości obrazów SPECT oceniano na podstawie kontrastu „gorących” źródeł oraz współczynnika zmienności tła (coefficient of variance, COV). Obrazy CT oceniono pod kątem szumu na obrazie oraz CTDIvol.

WYNIKI: Nie wykazano istotnej różnicy pomiędzy wartościami kontrastu „gorących” źródeł oraz parametru COV na obrazach SPECT zrekonstruowanych w oparciu o obrazy CT uzyskane dla analizowanych kombinacji napięć oraz natężeń prądu.

WNIOSKI: Jakość analizowanych obrazów SPECT nie ulegała istotnej zmianie, przy zmianie parametrów badania CT wykorzystywanego do korekcji AC badania SPECT. Na tej podstawie można stwierdzić, że użytkownik może wybrać dowolne parametry ekspozycji CT w analizowanym zakresie, nie wpływając znacząco na obraz SPECT. Wybór następującego zestawu parametrów badania CT: napięcie 10okV oraz natężenie prądu $70 \mathrm{~mA}$, lub napięcie $120 \mathrm{kV}$ oraz natężenie prądu 40mA, pozwala na potencjalne obniżenie narażenia pacjenta o około 25\%, przy podniesieniu szum na obrazie o około 15\%. Niniejsze badanie przedstawia kierunek działań koniecznych przy wdrażaniu zindywidualizowanych procedur diagnostycznych SPECT/CT.

\section{EP-DO-113: Ocena ACS systemu tomograficznego (Philips Brilliance) Dominika Oborska-Kumaszyńska ${ }^{1}$}

(1) The Royal Wolverhampton NHS Trust, MPCE Department, England

WPROWADZENIE: Celem projektu było dopuszczenie systemu TK (Philips Brilliance ver.4.2.0.17057) do uzytku klinicznego w radioterapii. Częścią projektu była ocena działania systemu ACS w zakresie parametrów jakościowych i ilosciwych obrazow. Założeniem było, ze system ACS powinien kompensować warunki obrazowania, determinowane rozmiarem pacjenta, uwzględniając jakość obrazu, parametry ilościowe i dawkę.

MATERIAŁ I METODA: Dla wszystkich zaimplementowanych protokołów klinicznych oceniono ACS w funkcji jakości obrazu (SD, SNR, CNR, kontrast), parametrów ilościowych (HU, SD) oraz dawki (CTDIs). Rekonstrukcje wykonano dla wszystkich zaimplementowanych protokołów klinicznych używając fantomów: CATPHAN60o, CIRS, obiekty testowe Philips (15cm-50cm średnicy). Poddano ocenie jakościowej i ilościowej parametry obrazów. Porównano je również dla protokołów ze stałym mAs vs ACS.

WYNIKI: W pełnym zakresie protokołów klinicznych dla CATPHAN6oo kontrast (polistyren vs LDPE) wynosił 0.5-1.2. Wartości CNR mieściły się w zakresie 9.0-23.3. SD, zmierzone dla obiektów testowych Phlips, 
w zależności od typu skanu (protokoły dla głowy/filtr UB i reszta protokołów/filtr B) mieściło się w wartościach $\sim$ 4-7 (15cm) do 35-45 HU (5Ocm). Odpowiednio SNR 5-11 (15cm) do 2-7 (50cm). Jednorodność wynosiła $1.5-2,8 \%(15 \mathrm{~cm})$ do 14,0-59,1\% (50cm) w zależności od typu protokołu. Wyniki skutkowały rekalibracją systemu dla nowego fantomu systemowego oraz fantomu „eye”. Uzyskano prawidłowe wyniki w testach stałości i jakości obrazowania, natomiast nie poprawiło rezultatów dla systemu ACS. Dla protokołów ACS i z ustalonym mAs wyniki dla CIRS, dla gęstości poniżej tytanu, różniły się mniej niż 20HU. Dla tytanu i stali te różnice były większe, statystycznie z dużą dyspersją: -100-+90HU - tytan, -65- +230HU - stal chirurgiczna.

WNIOSKI: Kontrast nie wykazywał zależności od typu protokołu i warunków rekonstrukcji. Uzyskano zakładany efekt optymalizacji protokołów w układzie jakość obrazu vs dawka. Wartości CNR wykazywały zależność od warunków skanowania i rekonstrukcji (filtr, grubość skanowanej i rekonstruowanej warstwy). Uzyskane wyniki dla systemu ACS w funkcji wielkości obiektu nie potwierdziły, że system działa efektywnie. Potwierdzono porównywalność systemu ACS dla HU w stosunku do stałych mAs. Uzyskane rozbieżności HU dla materiałów o bardzo wysokiej gęstości wykazywały podobną rozbieżność jak między różnymi warunkami skanowania i rekonstrukcji.

\section{EP-DO-114: Grubość mięśni zewnątrzgałkowych a praca w bliży. Magdalena Grajek ${ }^{1}$ \\ (1) Zakład Elektroniki Kwantowej, Wydział Fizyki, Uniwersytet im.A. Mickiewicza, Poznań, Polska}

WPROWADZENIE: Sprawdzenie wpływu ilości godzin spędzanych w pracy w bliży wzrokowej na grubość mięśni zewnątrzgałkowych, mierzonych za pomocą USG

MATERIAŁ I METODA: Badaniem objęto grupę 90 ochotników w wieku 19 - 30 lat. Pomiarów dokonano ultrasonografem DESMIN M przy pomocy głowicy B o częstotliwości $12 \mathrm{MHz}$. By móc porównać wpływ ilości godzin na grubość mięśni badanych, badanych podzielono na podgrupy: pracujących w bliży wzrokowej poniżej lub równo $5 \mathrm{~h}$ dziennie oraz pracujących w bliży powyżej 5 h dziennie. Uzyskane wyniki opracowano statystycznie za pomocą programu STATISTICA 10. Uzyskane wyniki porównano z odpowiadającymi im normami ustalonymi dla populacji polskiej.

WYNIKI: Wyznaczono średnie wartości grubości mięśni: prostego przyśrodkowego, prostego bocznego, prostego górnego i prostego dolnego dla całej grupy badawczej oraz każdej z podgrup oddzielnie. Stwierdzono, że istnieje istotna statystycznie zależność pomiędzy ilością godzin spędzanych w pracy w bliży wzrokowej a grubością mięśni. Największemu pogrubieniu wraz ze wzrostem ilości godzin pracy w bliży uległ mięsień prosty przyśrodkowy. Szczególnie wysokie wartości grubości tego mięśnia odnotowano wśród tych graczy komputerowych, dla których występuje najsilniejsza dodatnia korelacja grubości mięśni z ilością godzin pracy w bliży spośród wszystkich badanych.

WNIOSKI: Po przeanalizowaniu wpływu ilości czasu pracy w bliży na grubość mięśni zewnątrzgałkowych stwierdzono, że istnieje istotny statystycznie związek grubości mięśni z ilością godzin spędzanych w pracy w bliży wzrokowej: im więcej deklarowanych godzin w pracy w bliży wzrokowej tym grubsze stają się mięśnie proste przyśrodkowe, mięśnie proste górne i mięśnie proste boczne.

Największemu pogrubieniu wraz ze wzrostem ilości godzin pracy w bliży ulegał mięsień prosty przyśrodkowy. Szczególnie wysokie wartości grubości tego mięśnia odnotowano wśród graczy komputerowych.

W grupie tej występuje najsilniejsza dodatnia korelacja grubości mięśni z ilością godzin pracy w bliży spośród wszystkich badanych.

Na grubość mięśni prostych przyśrodkowych wpływa nie tylko ilość godzin spędzanych w pracy w bliży, ale i intensywność wysiłku wzrokowego.

\section{EP-DO-115: Analiza tekstury obrazów radiologicznych RVG w procesie gojenia po utracie masy kostnej}

Ewelina Bębas ${ }^{1}$, Marta Borowska ${ }^{1}$, Janusz Szarmach², Edward Oczeretko ${ }^{1}$

(1) Zakład Biocybernetyki i Inżynierii Biomedycznej Politechniki Białostockiej, Białystok, Polska 
(2) Zakład Chirurgii Stomatologicznej Uniwersytetu Medycznego w Białymstoku, Polska

WPROWADZENIE: Celem pracy jest określenie różnic w wartościach cech tekstury obszarów obrazów radiologicznych uzyskanych metodą radiografii cyfrowej RVG. Obszar zainteresowania obejmuje miejsce, w którym leczone były ubytki kostne. Obserwowany był proces gojenia poresekcyjnych i potorbielowych ubytków.

MATERIAŁ I METODA: Badania zostały przeprowadzone przy użyciu programu MaZda (skrót od „macierz zdarzeń”) do wyznaczania statystycznych cech opisujących teksturę obrazu. Jest to darmowy program dostępny w Internecie, którego autorami są dr Piotr Szczypiński, mgr Marcin Kociołek oraz dr Michał Strzelecki.

Obrazy będące przedmiotem badań prezentują proces leczenia ubytków śródkostnych z zastosowaniem wszczepów ksenogennych. Stopień odbudowy ubytków śródkostnych zanalizowano za pomocą radiografii cyfrowej porównując obraz RTG wykonany bezpośrednio po zabiegu oraz po 12 miesiącach od zabiegu u tych samych pacjentów. Zostały one wykonane w Zakładzie Chirurgii Stomatologicznej Uniwersytetu Medycznego w Białymstoku. Do analizy użyto wcześniej przygotowane wycinki obrazów określające potrzebny do badania obszar.

WYNIKI: Przeprowadzona analiza pozwoliła określić wartości różnych parametrów statystycznych tekstury obrazów. Wykazują one różnice w przypadku obszarów po zabiegu oraz po roku od zabiegu.

WNIOSKI: Przeprowadzona analiza pozwala określić różnicę pomiędzy wartościami parametrów tekstury obszarów bezpośrednio po zabiegu oraz po roku od zabiegu. Warto zauważyć, że wartości te w przypadku obrazów wykonanych po roku od zabiegu wykazują statystyczne podobieństwo do obszarów zdrowych. Wskazuje to na powodzenie zabiegu i powodzenie procesu gojenia.

\section{EP-DO-116: Ocena zastosowania PTMTC jako sensora natlenienia do multimodalnego} obrazowania in vivo

Agnieszka Boś-Liedke ${ }^{1,2}$, Magdalena Walawender ${ }^{1}$, Anna Woźniak ${ }^{1}$, Dorota Flak ${ }^{1}$, Stefan Jurga ${ }^{1,2}$, Małgorzata Kucińska ${ }^{3}$, Adam Plewiński ${ }^{3}$, Marek Murias ${ }^{3}$, Marwa Elewa ${ }^{4}$, Lisa Lampp ${ }^{5}$, Peter Imming5, Krzysztof Tadyszak ${ }^{1,6}$

(1) NanoBioMedical Centre, Adam Mickiewicz University, Poznań, Poland

(2) Faculty of Physics, Adam Mickiewicz University, Poznań, Poland

(3) Department of Toxicology, Poznan University of Medical Sciences, Poznan, Poland

(4) Faculty of Pharmacy, Suez Canal University, Ismailia, Egypt

(5) Institute of Pharmacy, Martin Luther University Halle-Wittenberg, Halle (Saale), Germany

(6) Institute of Molecular Physics, Polish Academy of Sciences, Poznań, Poland

WPROWADZENIE: Stężenie tlenu w tkankach jest jednym z najistotniejszych parametrów fizjologicznych warunkujących prawidłowe funkcjonowanie każdego organizmu. Hipoksja jest natomiast stowarzyszona z różnorodnymi procesami patofizjologicznymi. Na szczególną uwagę zasługuje hipoksja obserwowana w guzach nowotworowych. W dużej mierze jej obecność warunkuje powodzenie terapii, a jej poprawna kwantyfikacja jest wartością prognostyczną. Pochodne TAM (ang. Triaryl methyl) są powszechnie stosowanymi sensorami używanymi do mapowania natlenienia tkanek metodą EPR (ang. Electron Paramagnetic Resonance), sensory te nie są jednak pozbawione istotnych działań ubocznych. Celem poniższych badań jest określenie własności tris(2,3,5,6-tetrachloro-4-carboxyphenyl)methyl (PTMTC) pochodnej TAM - jako potencjalnegozwiązku multimodalnego do badań fluorescencyjnych oraz EPR.

MATERIAŁ I METODA: PTMTC został przeanalizowany spektralnie przy użyciu spektrometru EPR oraz scharakteryzowany poprzez określenie czułości związku na tlen w środowisku płynnym odpowiednim dla iniekcji dożylnych (1mM PBS, pH = 7.4). Emisja fluorescencyjna związku oraz jego wydajność kwantowa została zmierzona w tym samym rozpuszczalniku. Test cytotoksyczności in vitro wykonano na dwóch liniach nowotworowych (HT-29 oraz FaDu). Stabilność PTMTC została określona w różnych roztworach (PBS pH = 7.4, dwa media komórkowe, krew szczurza oraz osocze). Ostatecznie toksyczność związku została również określona na modelu zwierzęcym. 
WYNIKI: Wyniki spektralne potwierdziły własności multimodalne związku PTMTC. Zarówno testy in vitro jak in vivo wskazały na nietoksyczny charakter związku, który może być podany do dawki $250 \mathrm{mg} / \mathrm{kg}$ BW (ang. body weight) zarówno dożylnie jak i dootrzewnowo.

WNIOSKI: PTMTCjestzwiązkiem o właściwościach kontrastowym do multimodalnych(EPR/spektroskopia fluorescencyjna) badań preklinicznych.

\section{EP-DO-117: Diagnostyka obrazowa przy wykorzystaniu metod medycyny nuklearnej a narażenie kobiety w ciąży Agnieszka Kuchcińska ${ }^{1}$}

(1) SZEDAR Laboratorium Badawcze, Polska

WPROWADZENIE: Celem pracy jest analiza narażenia kobiet w ciąży poddawanych procedurom z zakresu diagnostyki obrazowej wykorzystującej metody medycyny nuklearnej dla wybranych procedur oraz radioizotopów z uwzględnieniem możliwych skutków stochastycznych oraz deterministycznych dla płodu.

MATERIAŁ I METODA: W ramach materiału badawczego analizowano raporty, dokumenty oraz materiały szkoleniowe: Międzynarodowej Komisji ds. Ochrony Radiologicznej (ICRP), Międzynarodowej Agencji Energii Atomowej (IAEA), oraz materiały prezentowane podczas warsztatów Europejskiej Federacji Organizacji Fizyki Medycznej (EFOMP) organizowanych podczas europejskiego kongresu radiologicznego (ECR). Analizowano raportowane poziomy dawek na płód dla wybranych procedur z zakresu diagnostyki obrazowej wykorzystującej metody medycyny nuklearnej versus kryteria narażenia płodu (skutki deterministyczne i stochastyczne) w zależności od dawki promieniowania. Badano uzasadnienie (lub jego brak) dla odpowiednich procedur diagnostycznych oraz radioizotopów

WYNIKI: Raporty ICRP podają, że dawki dla płodu poniżej 10omGy nie powinny być przyczyną rozważania aborcji natomiast dawki poniżej 10mGy związane są z bardzo ograniczonym ryzykiem dla płodu. Materiały z warsztatów szkoleniowych EFOMP wskazują, że dawki, wyznaczone za pomocą metod symulacji Monte Carlo, dla płodu przy procedurach obrazowania z użyciem FDG (radioizotop F18) dla administrowanej aktywności $350 \mathrm{MBq}$ wiążą się z dawką dla płodu $10 \mathrm{mGy}$ we wczesnej ciąży oraz 4 mGy w 9 miesiącu ciąży, Natomiast procedury z użyciem Tc99m:

- perfuzja płuc (MAA), aktywność $200 \mathrm{MBq}$, dawka dla płodu o,8 mGy we wczesnej ciąży oraz o,8 mGy w 9 miesiącu ciąży

- ocean funkcjonowania nerek (MAG3), aktywność $200 \mathrm{MBq}$, dawka dla płodu 1,8 mGy we wczesnej ciąży oraz 0,4 mGy w 9 miesiącu ciąży

- skanowanie kości (MDP), aktywność 6oo MBq, dawka dla płodu 3,8 mGy we wczesnej ciąży oraz 1,4 mGy w 9 miesiącu ciąży

WNIOSKI: Większość procedur diagnostycznych medycyny nuklearnej jest wykonywana przy wykorzystaniu krótko-życiowych radionuklidów takich jak Tc99m, które w związku z powyższym nie generują wysokich dawek dla płodu. Procedury diagnostyki obrazowej z wykorzystaniem metod medycyny nuklearnej dla pacjentki w ciąży muszą zostać uzasadnione klinicznie. Dawki dla płodu podczas większości prawidłowo wykonanych i zoptymalizowanych badań diagnostycznych z zakresu medycyny nuklearnej nie powodują mierzalnego wzrostu ryzyka raka w wieku dziecięcym, defektów płodu ani obniżenia IQ

EP-DO-118: Bezpieczeństwo pacjenta i personelu w procedurach Magnetycznego Rezonansu Jądrowego

Agnieszka Kuchcińska ${ }^{1}$

(1) SZEDAR Laboratorium Badawcze, Polska

WPROWADZENIE: Celem pracy jest analiza ryzyka związanego z procedurami Magnetycznego Rezonansu Jądrowego dla pacjentów oraz personelu

MATERIAŁ I METODA: W ramach materiału wykonano przegląd literatury fachowej w zakresie 
bezpieczeństwa pacjentów i personelu podczas wykonywania procedur diagnostycznych z wykorzystaniem Magnetycznego Rezonansu Jądrowego, w szczególności materiały z warsztatów MRI workshop odbywających się wraz z konferencją 8 Europejską Konferencją Fizyki Medycznej - Ateny 2014. Analizowano efekty związane z występowaniem statycznego pola magnetycznego, gradientowego pola magnetycznego oraz pola RF. Uwzględniono analizę ryzyka procedur MRI dla kobiet w ciąży oraz płodu. Analizowano efekty związane z występowaniem implantów, stosowaniem środków kontrastowych oraz efekty kriogeniczne

WYNIKI: Stałe pole magnetyczne wiąże się z możliwość przyciągnięcia elementów metalowych oraz występowaniem tzw. efektu magnetohydrodynamicznego (MHD). Przepływ krwi w obecności statycznego wysokiego pola magnetycznego indukuje podwyższenie napięcia. Przy polach $1.5 \mathrm{~T}$ znaczące zmiany nie są oczekiwane, jednakże przy polu 6T efekt ten wiąże ze zmianą ciśnienia krwi o około 10\%. Gradientowe pole magnetyczne powoduje występowanie tzw. prądów indukowanych, stymulowanie nerwów obwodowych oraz implantów jak również powoduje szum akustyczny (charakterystyczne efekty dźwiękowe) mogący dochodzić od 80 - $115 \mathrm{~dB}$. Występowanie pola RF wiąże się z efektami podgrzewania ciała pacjenta, mierzony poprzez wielkość SAR (specific absorption rate) [W/kg]. Dodatkowe porady mogą być indukowane poprzez występowanie pętli materiałów przewodzących (np. kable implantów, kable cewek nadawczo-odbiorczych). Zagrożenie dla implantów to min. możliwość ich przesunięcia, zakłócenie ich normalnego działania (defibrylatory, pompy insuliny). Ponad 300 urządzeń medycznych było testowanych i ocenianych pod katem wpływu MRI na ich funkcjonowanie oraz wpływu na jakość obrazu

WNIOSKI: Procedury diagnostyczne wykorzystujące technikę Magnetycznego Rezonansu Jądrowego nie wiążą się ze stosowaniem promieniowania jonizującego, jednakże wiążą się z występowaniem efektów dla pacjenta oraz personelu w związku z występowaniem stałego pola magnetycznego, gradientowego pola magnetycznego oraz pola RF w tym efekty podgrzewania ciała pacjenta (wskaźnik SAR), jak również efektów dźwiękowych i możliwych przypadków efektów kriogenicznych. Ze względu na powyższe bezpieczeństwo procedur MRI powinno być nadzorowane przez personel wykonujący badania w szczególności mając na uwadze ocenę możliwości wykonania badania przy wszczepionych implantach. 


\section{INDEKS AUTORÓW}

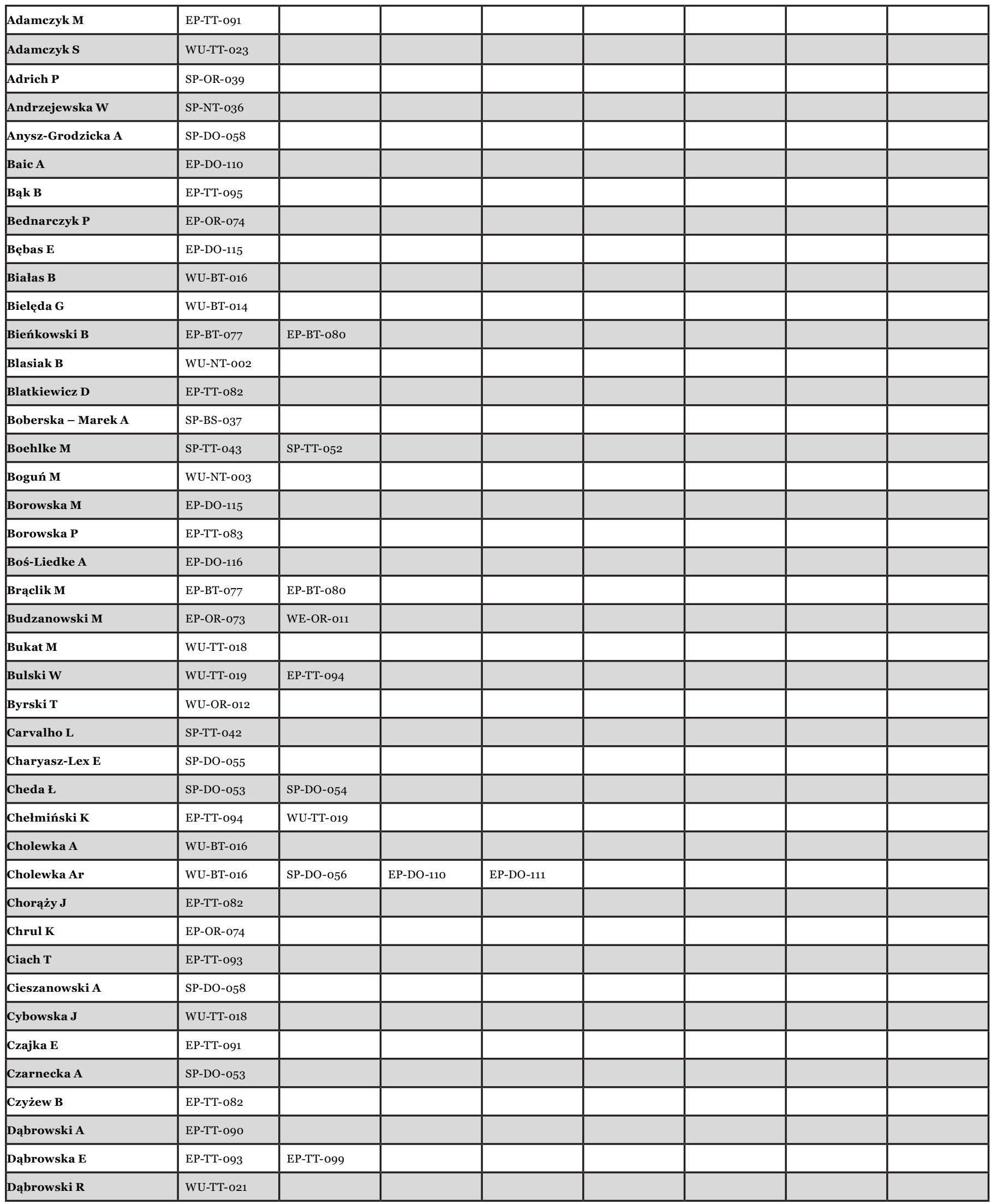




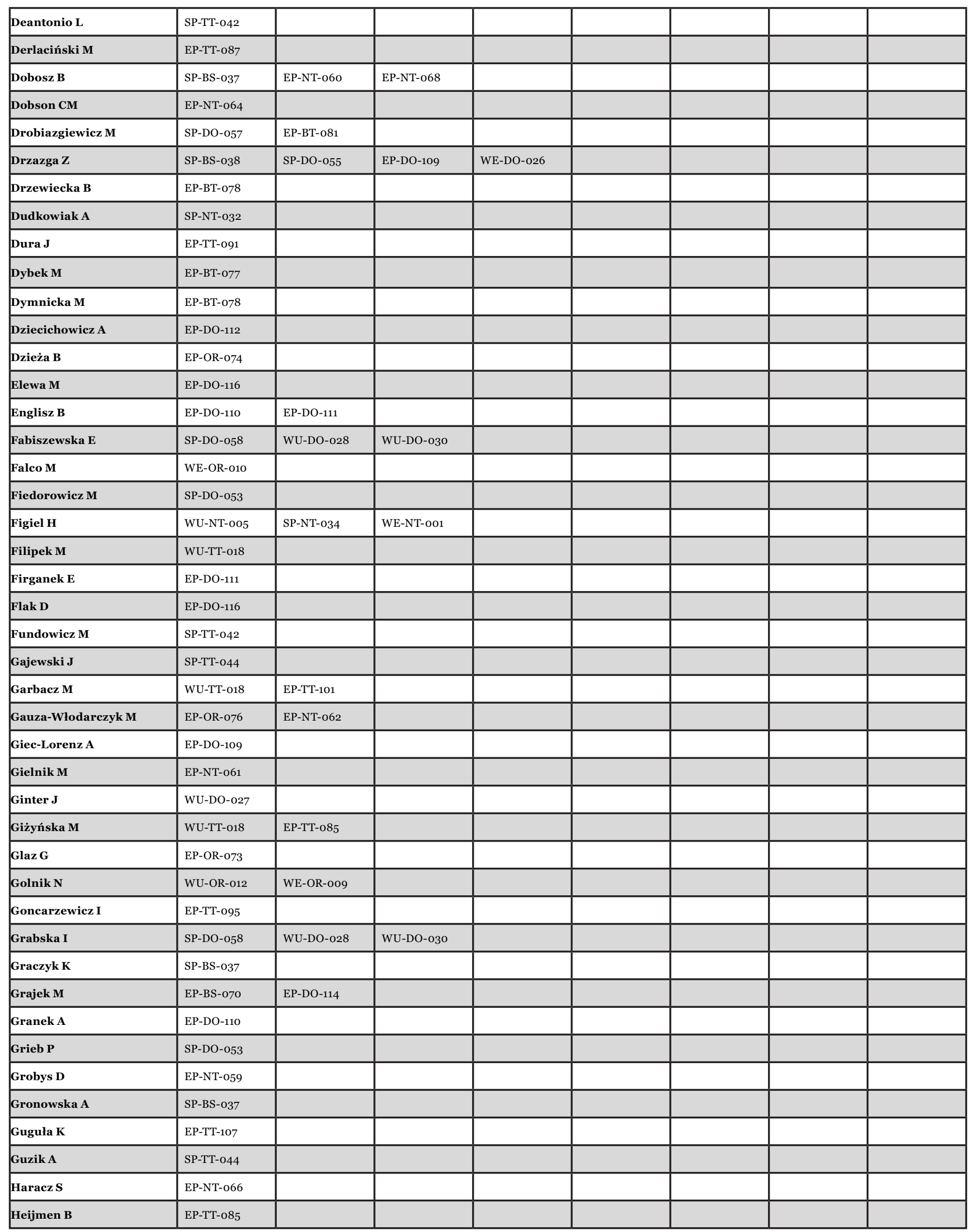




\begin{tabular}{|c|c|c|c|c|c|c|c|c|}
\hline Hładuński M & WU-DO-029 & & & & & & & \\
\hline Hojan-Jezierska D & EP-NT-062 & EP-BS-069 & EP-BS-071 & EP-BS-072 & WE-BS-007 & & & \\
\hline Hołub A & SP-TT-05O & & & & & & & \\
\hline Imming $P$ & EP-DO-116 & & & & & & & \\
\hline İ̇ykowska J & EP-NT-063 & EP-NT-065 & & & & & & \\
\hline Jackowiak W & WU-TT-023 & & & & & & & \\
\hline Janiga P & EP-TT-091 & & & & & & & \\
\hline Janiszewska M & SP-TT-045 & SP-DO-057 & EP-BT-o81 & EP-TT-097 & EP-TT-098 & WU-TT-022 & & \\
\hline Janowska P & EP-OR-073 & & & & & & & \\
\hline Jasieniak J & SP-DO-058 & & & & & & & \\
\hline Jezierska K & SP-TT-043 & & & & & & & \\
\hline Jodda A & EP-TT-091 & EP-TT-095 & & & & & & \\
\hline Józefczak A & SP-NT-031 & & & & & & & \\
\hline Jurga S & EP-NT-065 & EP-DO-116 & & & & & & \\
\hline Jurgilewicz D & WU-DO-029 & & & & & & & \\
\hline Juszczak M & WU-NT-oo3 & & & & & & & \\
\hline Kabacińska R & WU-BT-015 & EP-BT-079 & & & & & & \\
\hline Kabat D & WU-OR-012 & EP-DO-112 & EP-TT-084 & & & & & \\
\hline Kaczmarek K & SP-NT-o31 & EP-TT-095 & & & & & & \\
\hline Kaczorowska E & EP-TT-087 & & & & & & & \\
\hline Kaczyńska A & WU-NT-004 & & & & & & & \\
\hline Kajdrowicz T & EP-TT-107 & & & & & & & \\
\hline Kamińska J & SP-TT-048 & SP-TT-051 & & & & & & \\
\hline Kamińska M & SP-DO-053 & & & & & & & \\
\hline Kapek L & WU-BT-016 & & & & & & & \\
\hline Karewicz A & WU-NT-004 & & & & & & & \\
\hline Karpiel I & SP-DO-055 & & & & & & & \\
\hline Kasprzyk T & EP-DO-110 & SP-DO-056 & & & & & & \\
\hline Kawałkiewicz W & EP-BS-071 & EP-BS-072 & & & & & & \\
\hline Kawecki M & EP-DO-111 & & & & & & & \\
\hline Kaźmierska J & WU-TT-020 & & & & & & & \\
\hline Kellas-Slęczka S & WU-BT-016 & & & & & & & \\
\hline Khan MI & SP-DO-053 & & & & & & & \\
\hline Kiersznowska Z & EP-OR-076 & & & & & & & \\
\hline Kijeska W & SP-BS-037 & & & & & & & \\
\hline Kilian K & SP-DO-053 & SP-DO-054 & & & & & & \\
\hline Kiraga $\mathbf{E}$ & SP-DO-054 & & & & & & & \\
\hline Kiszkurno A & EP-OR-073 & & & & & & & \\
\hline Klose U & SP-DO-055 & & & & & & & \\
\hline Kluska A & ЕР-TT-088 & & & & & & & \\
\hline Kmita A & WU-NT-004 & WU-NT-005 & & & & & & \\
\hline Knefel G & EP-DO-111 & & & & & & & \\
\hline Knyziak AB & EP-TT-087 & & & & & & & \\
\hline Kociemba A & EP-BT-078 & & & & & & & \\
\hline Kocot M & WU-NT-003 & & & & & & & \\
\hline
\end{tabular}




\begin{tabular}{|c|c|c|c|c|c|c|c|c|}
\hline Kołodziejska $\dot{\mathbf{Z}}$ & EP-NT-063 & EP-NT-059 & & & & & & \\
\hline Komar D & EP-BS-071 & & & & & & & \\
\hline Komenda W & SP-TT-044 & & & & & & & \\
\hline Konat K & EP-BT-o81 & & & & & & & \\
\hline Konefal A & WU-TT-023 & & & & & & & \\
\hline Konstanty E & SP-TT-042 & & & & & & & \\
\hline Kopeć D & EP-TT-092 & & & & & & & \\
\hline Kopeć R & SP-TT-044 & EP-OR-074 & EP-TT-107 & & & & & \\
\hline Koras K & WU-DO-027 & & & & & & & \\
\hline Kościńska M & EP-OR-074 & & & & & & & \\
\hline Kot W & SP-TT-043 & & & & & & & \\
\hline Kotkowiak M & SP-NT-032 & SP-NT-032 & & & & & & \\
\hline Kowalik A & WU-TT-023 & & & & & & & \\
\hline Kowalska T & EP-DO-112 & & & & & & & \\
\hline Kowalski A & EP-TT-108 & & & & & & & \\
\hline Kowski R & WE-DO-024 & & & & & & & \\
\hline Kozak M & SP-NT-036 & EP-NT-059 & EP-NT-o61 & EP-NT-063 & EP-NT-064 & EP-NT-065 & EP-NT-066 & EP-NT-067 \\
\hline Kozłowski D & EP-TT-09o & & & & & & & \\
\hline Krak A & SP-NT-034 & & & & & & & \\
\hline Krengli M & SP-TT-042 & & & & & & & \\
\hline Król K & SP-NT-035 & & & & & & & \\
\hline Król M & SP-DO-054 & & & & & & & \\
\hline Kruczewska J & EP-NT-o6o & & & & & & & \\
\hline Kruk M & EP-OR-074 & & & & & & & \\
\hline Kruszyna-Mochalska M & SP-TT-042 & WU-TT-023 & EP-TT-089 & & & & & \\
\hline Krzempek D & SP-TT-044 & & & & & & & \\
\hline Krzyminiewski R & SP-BS-037 & EP-NT-o6o & EP-NT-o68 & WE-BS-0o6 & & & & \\
\hline Kubisz L & EP-NT-062 & EP-BS-071 & EP-BS-072 & & & & & \\
\hline Kuchcińska A & SP-OR-040 & EP-TT-103 & EP-DO-117 & EP-DO-118 & & & & \\
\hline Kucińska M & EP-DO-116 & & & & & & & \\
\hline Kukołowicz P & SP-TT-049 & SP-DO-058 & EP-TT-082 & EP-TT-085 & EP-TT-092 & EP-TT-093 & SP-TT-041 & \\
\hline Kulaszewski K & EP-BT-o81 & & & & & & & \\
\hline Kumita JR & EP-NT-064 & & & & & & & \\
\hline Kurczewska J & EP-NT-068 & & & & & & & \\
\hline Kwiatek W & EP-NT-o61 & & & & & & & \\
\hline Kwiatkowski R & EP-BT-077 & EP-BT-o8o & & & & & & \\
\hline Kycia R & EP-TT-084 & & & & & & & \\
\hline Lachowicz D & WU-NT-005 & WU-NT-004 & & & & & & \\
\hline Lampp L & EP-DO-116 & & & & & & & \\
\hline Latała A & EP-TT-099 & & & & & & & \\
\hline Latała Z & EP-TT-084 & & & & & & & \\
\hline Lewocki M & SP-TT-043 & WE-OR-010 & & & & & & \\
\hline Lichoń K & EP-BT-o81 & & & & & & & \\
\hline Liszka G & EP-DO-111 & & & & & & & \\
\hline Litoborska J & EP-TT-091 & & & & & & & \\
\hline
\end{tabular}




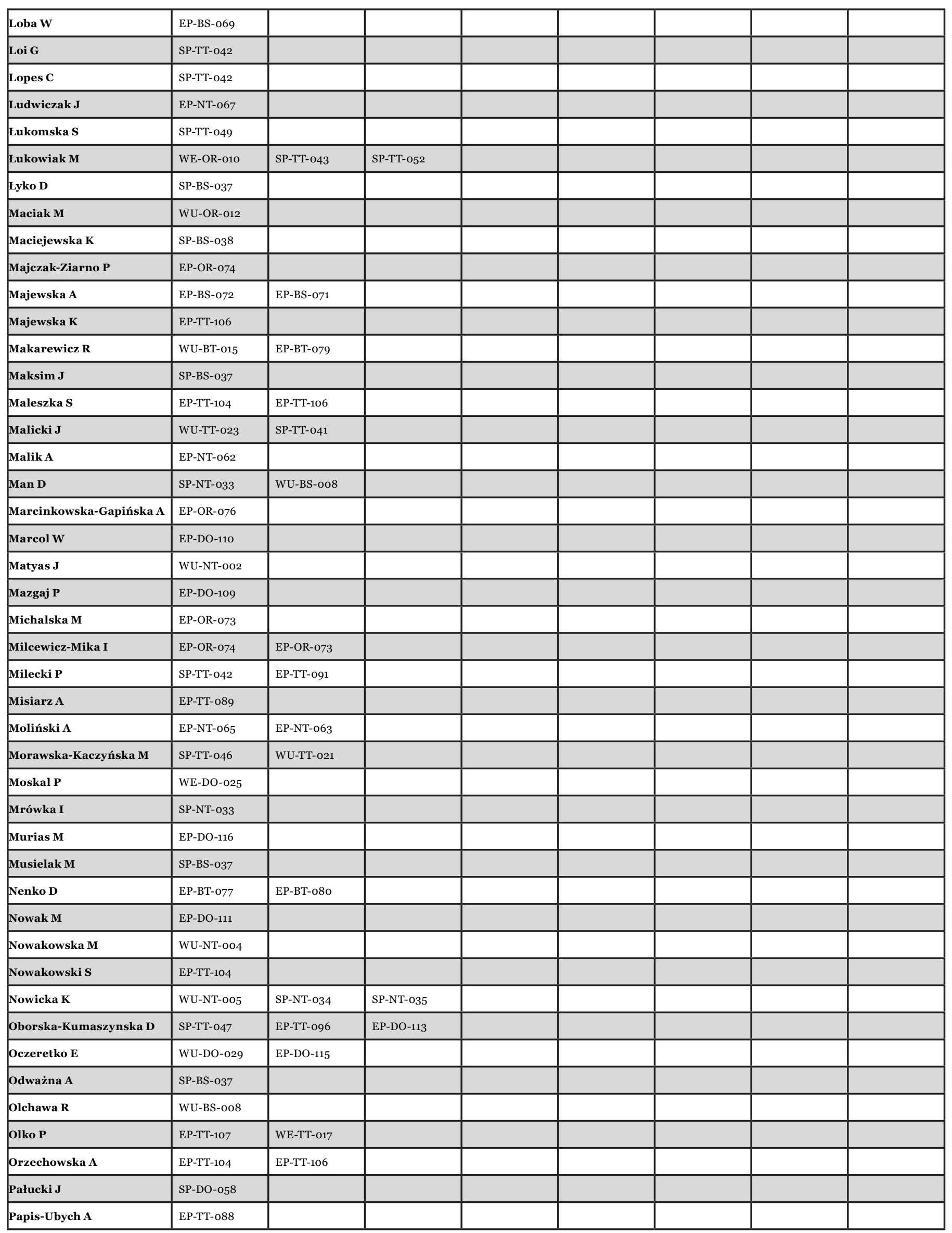




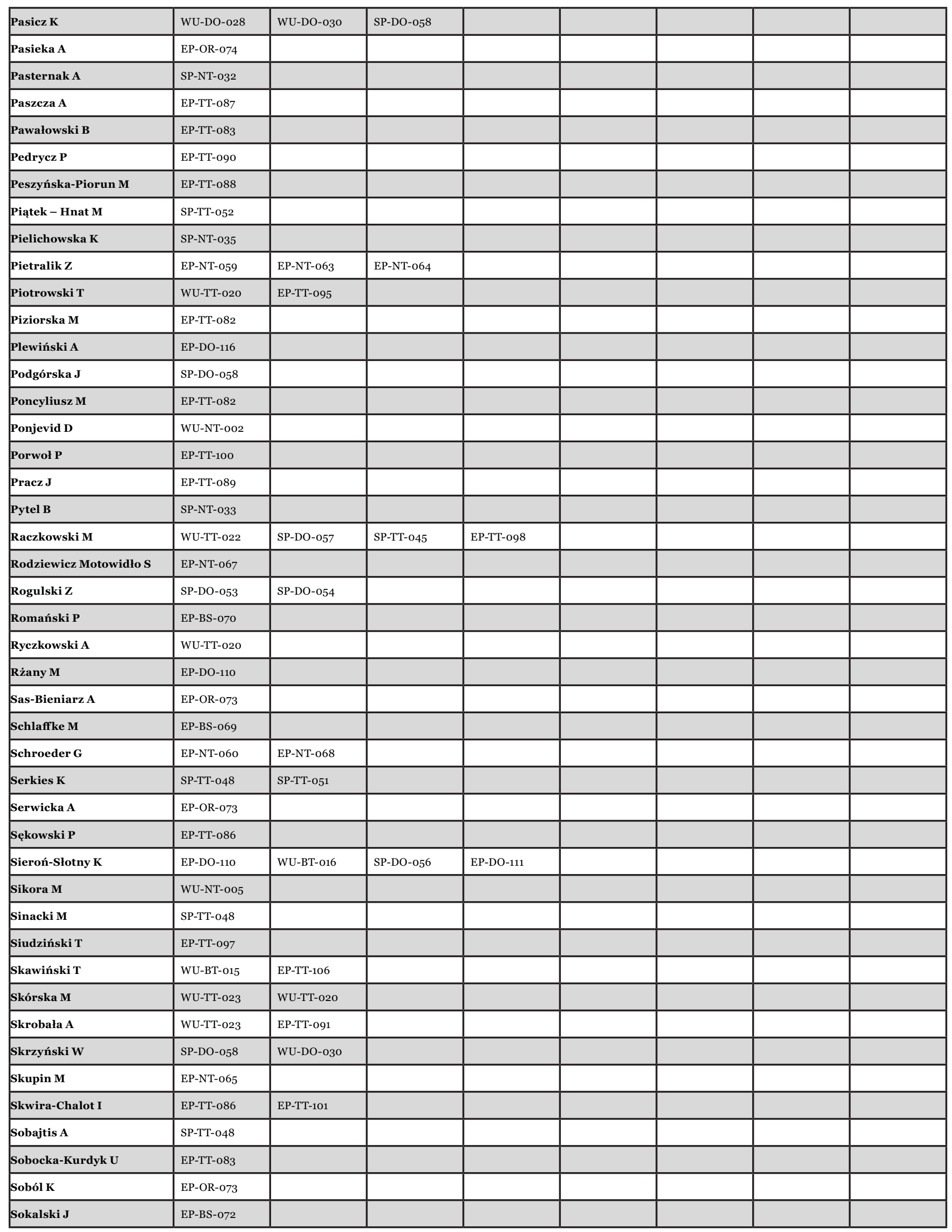




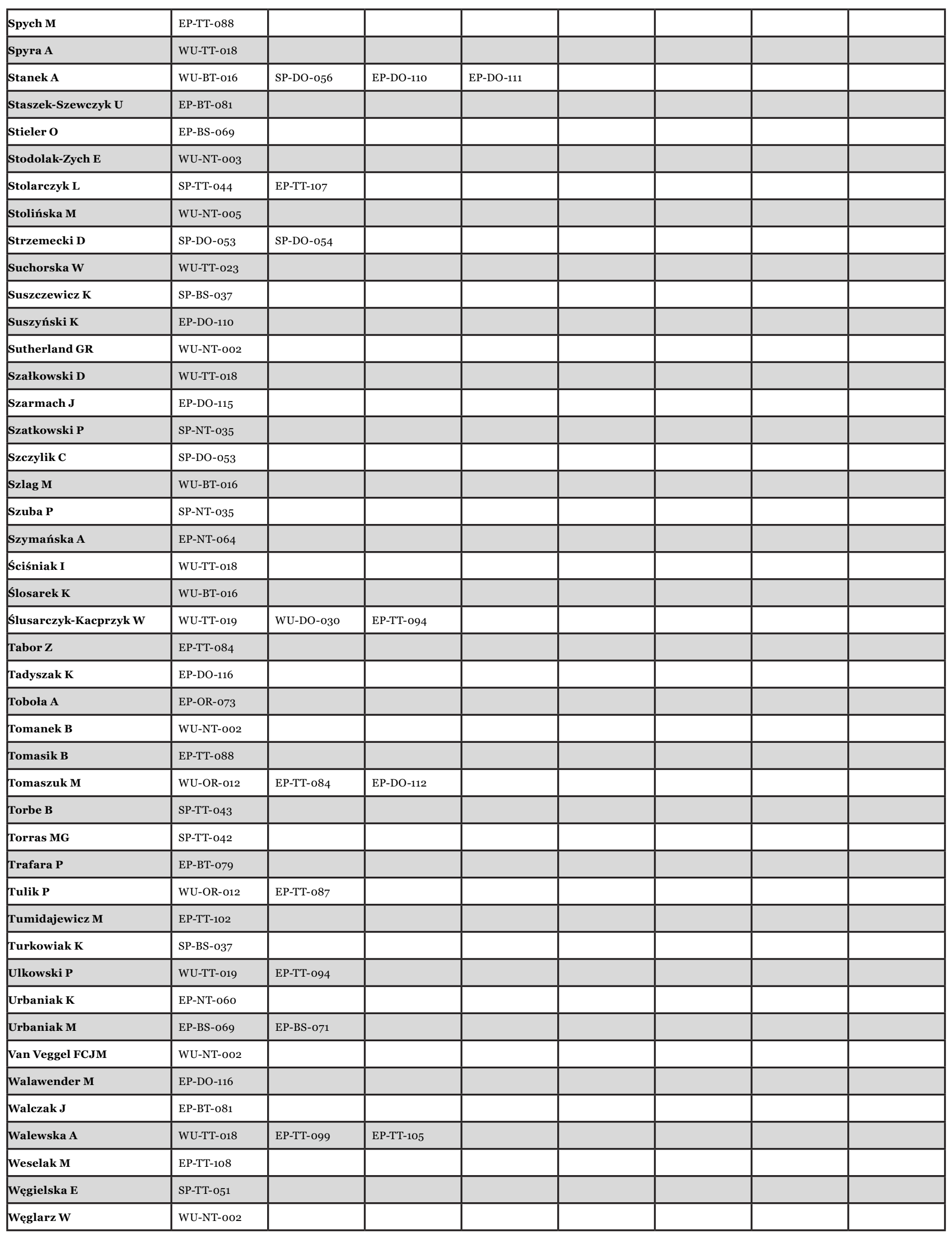




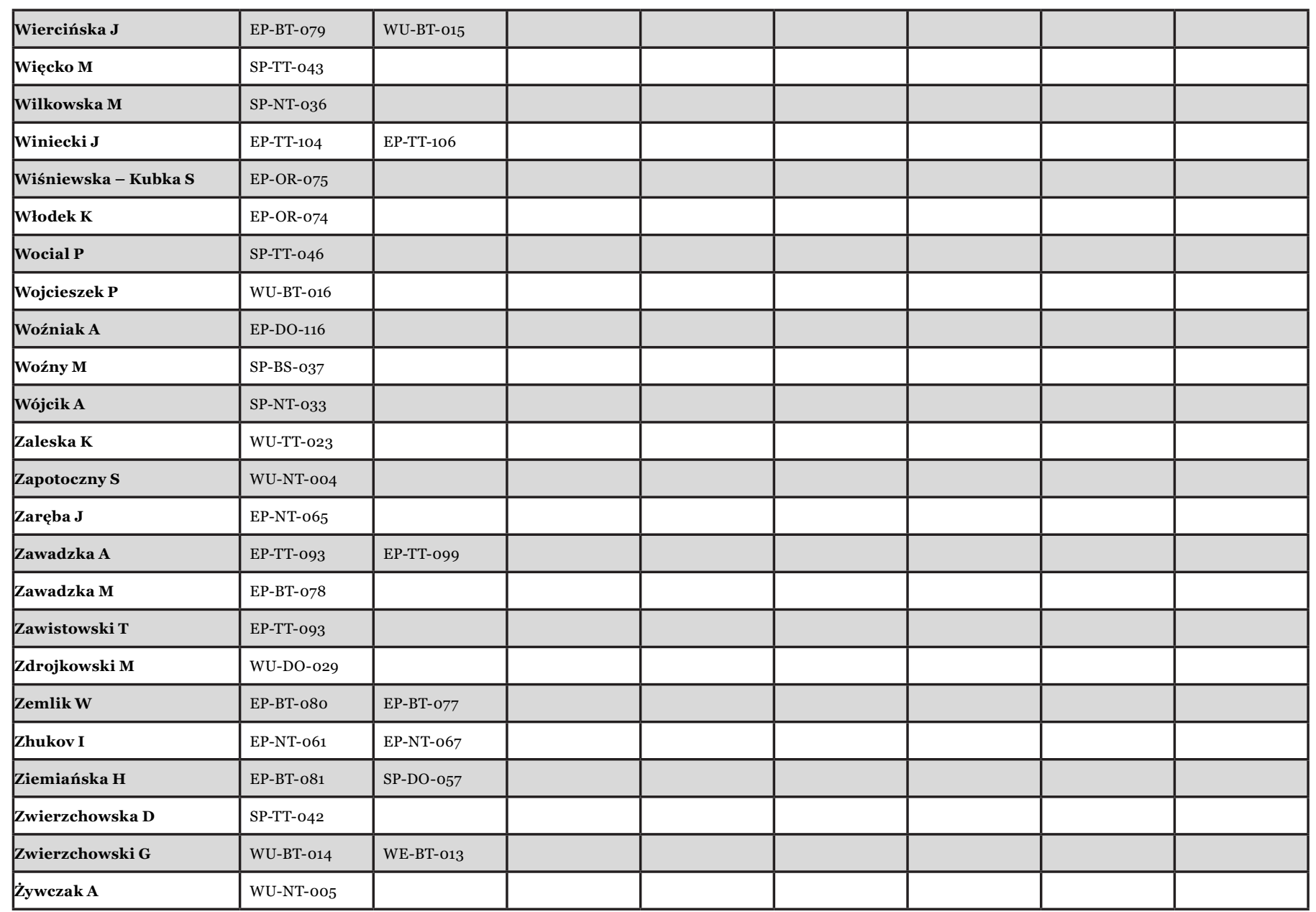

